\title{
At Play in the Archive: \\ Reading Sophie Calle's \\ Double Game as Autofictional Remains
}

\author{
by \\ Anna Khimasia
}

A thesis submitted to the Faculty of Graduate and Postdoctoral

Affairs in partial fulfillment of the requirements for the degree

Doctor Of Philosophy

in

Cultural Mediations

\author{
Carleton University \\ Ottawa, Ontario
}

(C) 2015

Anna Khimasia 


\begin{abstract}
In 1992 author Paul Auster borrowed eight projects from French artist Sophie Calle for Maria, a fictional character in his novel Leviathan; Auster also included two projects of his own invention. Calle, in return, enacted and documented these projects created by Auster and included them, along with her initial projects, in her book Double Game. Double Game begins with these words: "Intrigued by this double, I decided to turn Auster's novel into a game and to make my own particular mix of reality and fiction."1
\end{abstract}

Calle's autofictional projects seemingly describe events in her life: a job as a chambermaid, a job as a striptease artist, a day spent being followed by a detective. Calle's use of autofiction, a self-conscious play between autobiography and the novel, emphasizes the impossibility of a coherent and unified subject. I argue that Calle's book plays with structures and forms usually associated with truth telling (autobiography, archives, photography, the report, the diary) by constructing evidence that relies on these structures for legitimacy, only to expose gaps, inconsistencies, and fictions as a space for play and critique.

The French version of Double Game, a series of seven separate books, has the title Doubles-jeux. Jeu in French is understood to mean both game and play, while also a homonym for 'I' [je]. Doubles-jeux is a double-cross-to deceive and betray, in the sense of a red herring. Thus the title, Double Game,

\footnotetext{
${ }^{1}$ Sophie Calle with the participation of Paul Auster, Double Game (Paris: Violette Editions, 1999), 1.
} 
already speaks to Calle's autofictional accounts in which the narrating "l" is always unreliable and the events described always undecideable.

My dissertation focuses on the contingency of Calle's documents by highlighting the spaces between what is said to have happened, what we are shown, and what may have taken place. Aligning Calle's work with performance, and recent discussions about performance documentation, enables a more focused interrogation of the relationship between the event and its representation. My dissertation argues that as a collection of autofictional traces, Double Game performs the autofictional subject at play in the archive. 


\section{ACKNOWLEDGEMENTS}

I would like to express a sincere thank you to all those who have supported me in the process of completing this thesis. First and foremost I would like to thank my supervisors Professor Chris Faulkner and Professor Ming Tiampo whose guidance enabled me to complete this work. I would also like to express my appreciation to my readers Professor Carol Payne and Professor Jodie Medd for their support and generosity. Thank you to my outside readers, Professor Jayne Wark and Professor Laura Horak, for their insightful comments and questions.

I would also like to thank the Institute for Comparative Studies in Literature, Art and Culture (ICSLAC) at Carleton University where I completed my degree, particularly its Director Mitchell Frank who showed me unwavering support and encouragement. Thanks also to Dawn Schmidt at ICSLAC who guided me through the bureaucracy of being in school. My studies would not have been possible without the generous support of grants and scholarships. I thank Carleton University, Ontario Graduate Scholarship, S. F. Wise Graduate Bursary and the David and Rachel Epstein Foundation Scholarship. I also thank the Art History Department at Carleton who employed me throughout my PhD.

There are so many people without whom this journey would not have been possible. I thank my classmates and friends Thom Everrett, Kyle Devine and Pamela Barber who stimulated my intellectual growth and taught me all about Bruno Latour! I feel lucky to have had the support from so many friends. I thank Sandra Dyck, Anne De Stecher, Kate Barry, Bianca Briciu, Emma Lind, Bethany Gibson, Courtney Holmes, Sue Lofthouse, and Melissa Thompson who 
listened to me, offered advice, read through my work, and helped when things got too hectic or unruly. A massive thanks also to those friends who provided well-needed craziness in times of stasis: Action Jackson and Coleman, Missy and Peter, Scottie and France, Erik and Tania, Cork and Nyah, Juju, Bud and Natalie, Scott and Jas, So and Marcus, Bethany and Glenn, and SD and PC! A professor once told me that at the end of this process I would not have any friends remaining, so I feel especially lucky to have such close, supportive and fun friends! I thank my mum, Therese Khimasia who always found time to listen to me and provided words of encouragement throughout this process and my brothers, Dan and Dave, who found the levity in it all. To Pauline, Don and Cameron, I really could not have done this without you. I thank you from the bottom of my heart. Finally I thank my family, my daughters Maeve and Eva, and my partner Sean Lynch, whose patience, love, and humour enabled me to complete this dissertation. 


\section{TABLE OF CONTENTS}

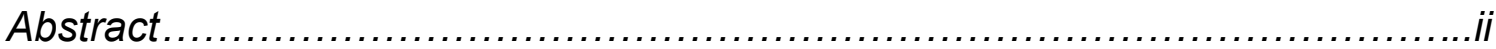

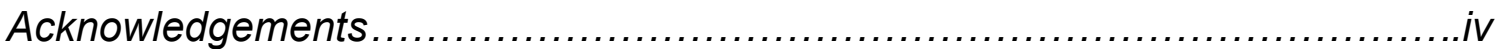

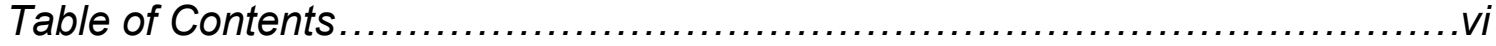

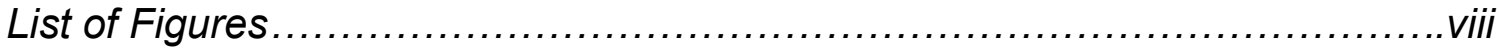

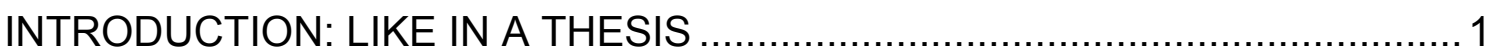

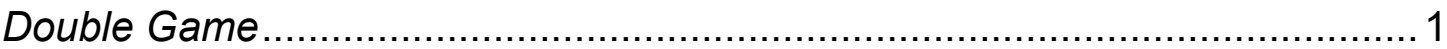

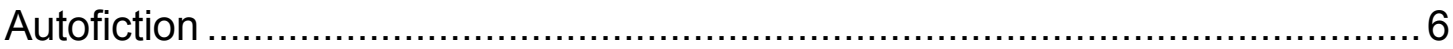

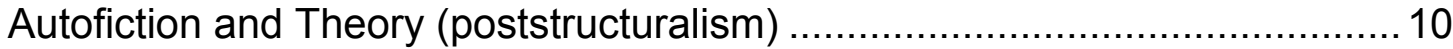

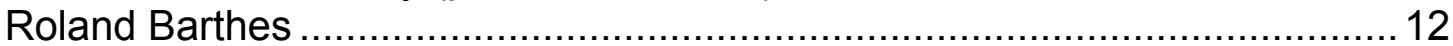

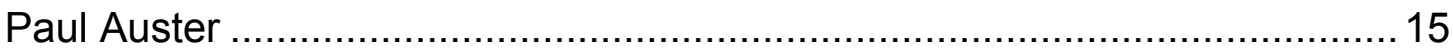

Autofiction and Performance Archive (the event and its traces) .................. 16

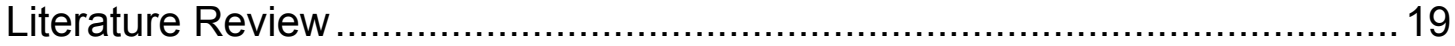

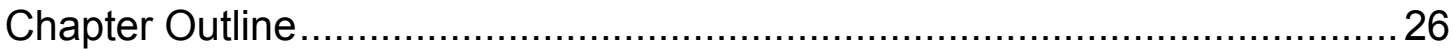

CHAPTER ONE: LIKE A CHARACTER OUT OF A NOVEL ..........................29

Calle's Annotated Pages of Auster's Leviathan .......................................... 30

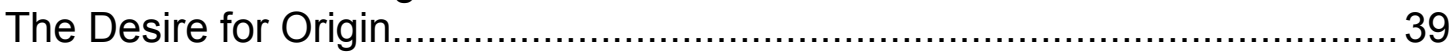

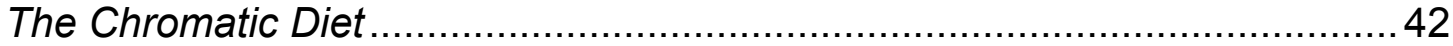

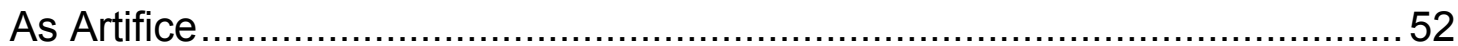

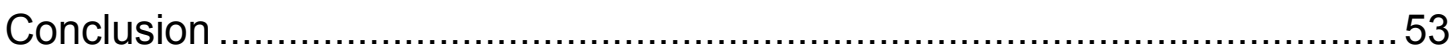

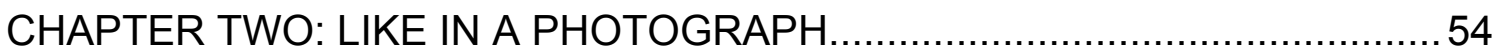

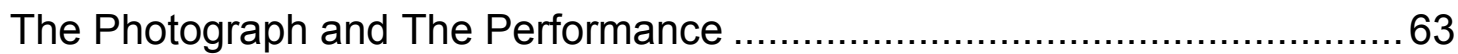

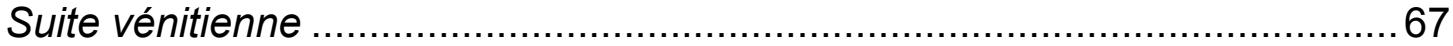

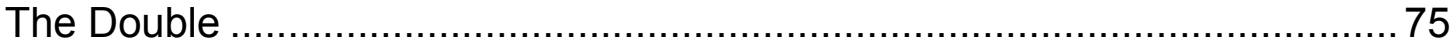

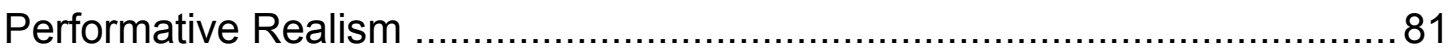

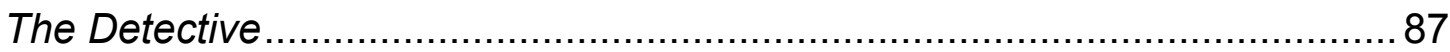

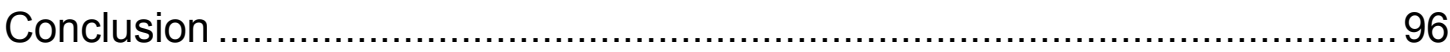

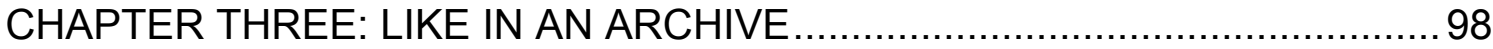

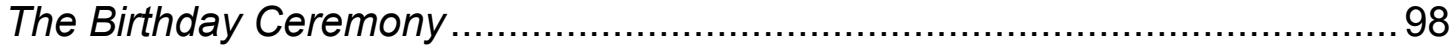

Days Under The Sign of B, C and W................................................ 110

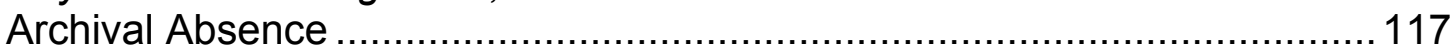

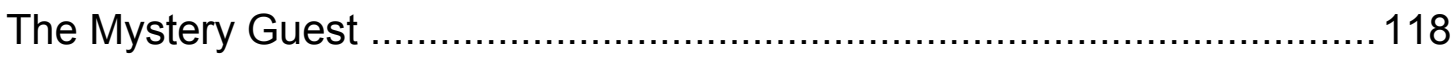

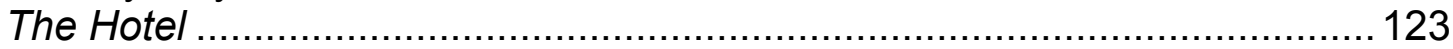

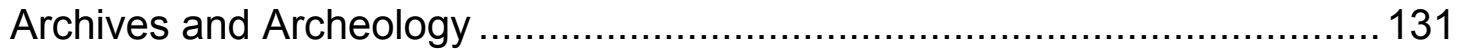

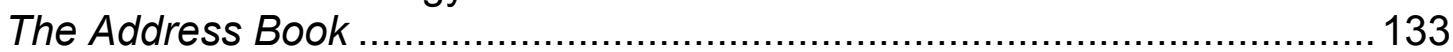

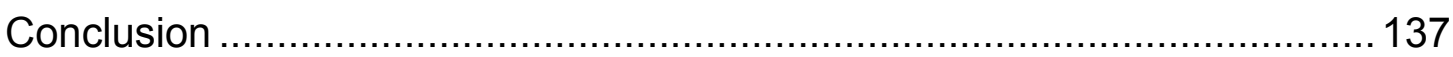

CHAPTER FOUR: LIKE THE FEMALE SUBJECT …..............................138

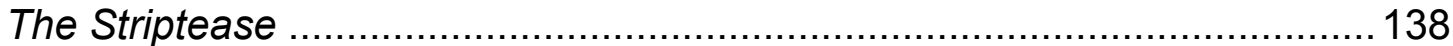

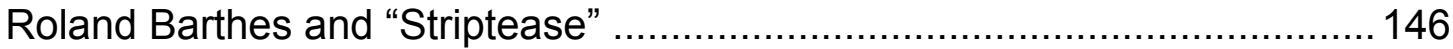

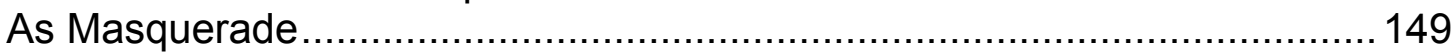

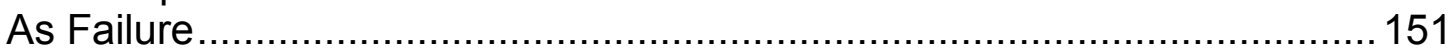




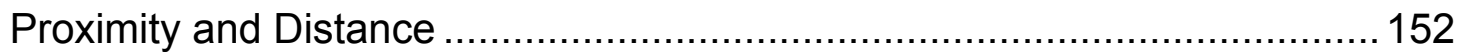

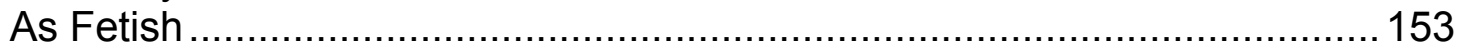

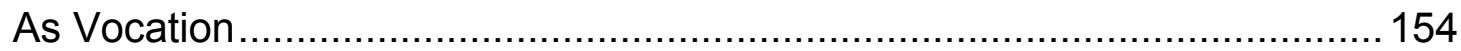

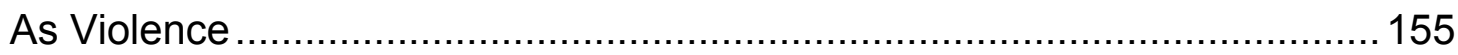

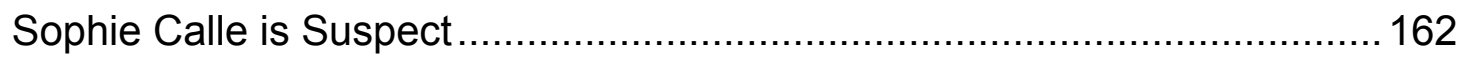

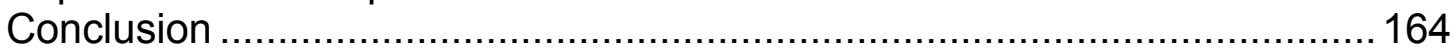

CHAPTER FIVE: CONSTRUCTING AN ARCHIVE .................................. 166

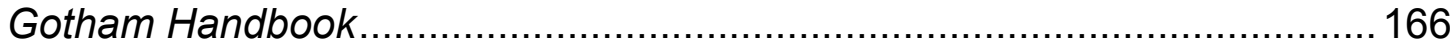

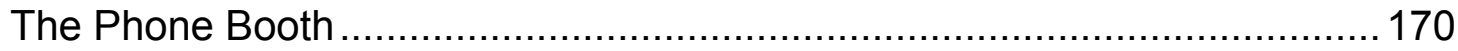

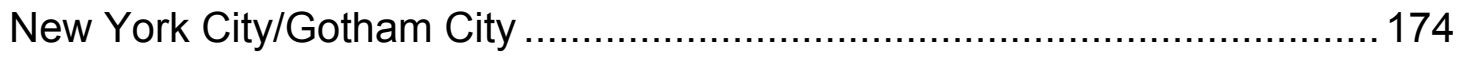

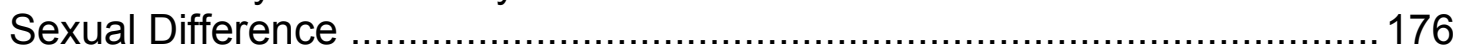

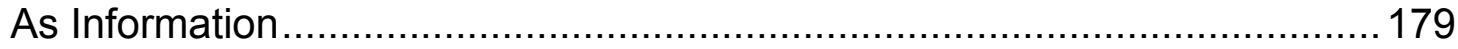

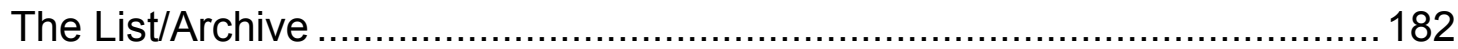

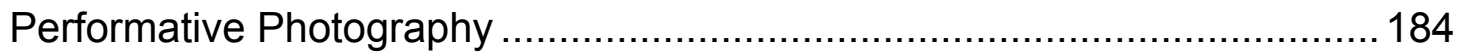

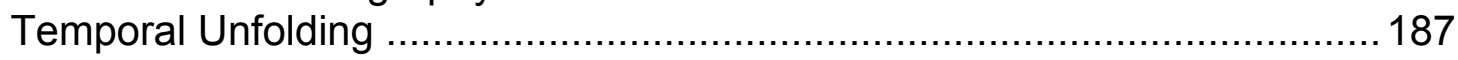

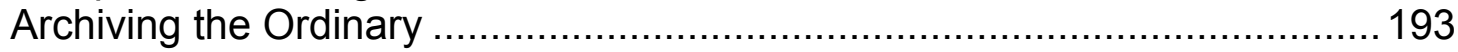

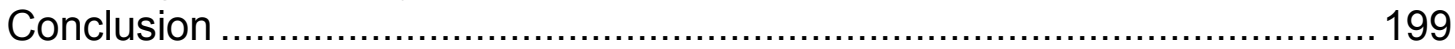

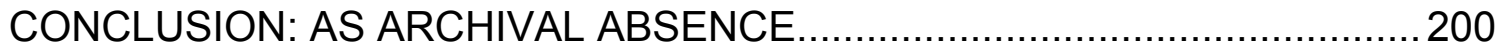

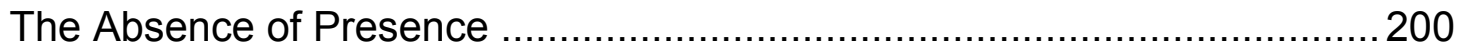

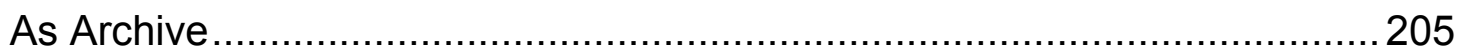

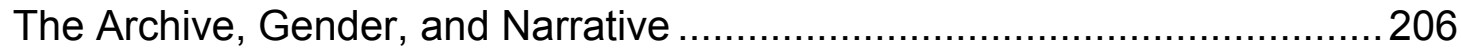

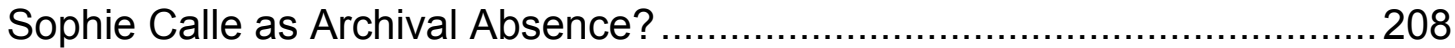

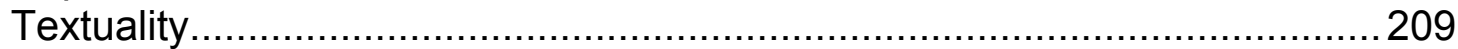

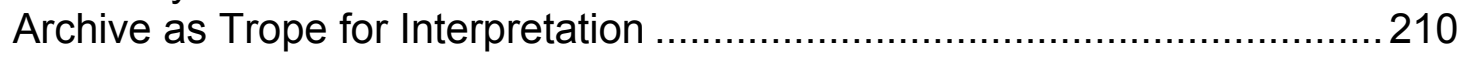

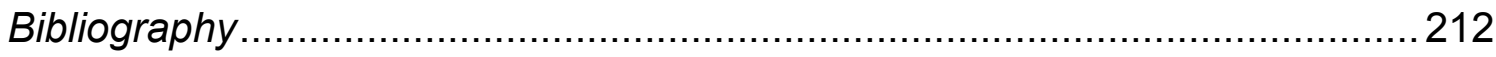




\section{LIST OF FIGURES}

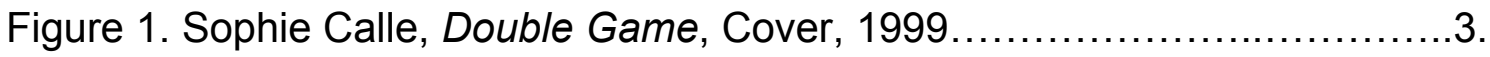

Figure 2. Sophie Calle, Double Game, Copyright Page, $1999 \ldots \ldots \ldots \ldots \ldots \ldots \ldots . . . . . . .5$.

Figure 3. Paul Auster, Leviathan, Copyright Page, 1992 .........................5.

Figure 4. Sophie Calle, annotated pages 64 and 65 from Paul Auster's

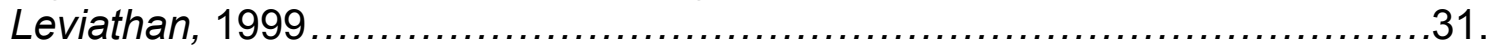

Figure 5. Roland Barthes, Roland Barthes by Roland Barthes, 1977 .............34.

Figure 6. Sophie Calle, Days Under the Sign of B, C and W, 1998..............36.

Figure 7. Sophie Calle, The Chromatic Diet, 1997 ............................44.

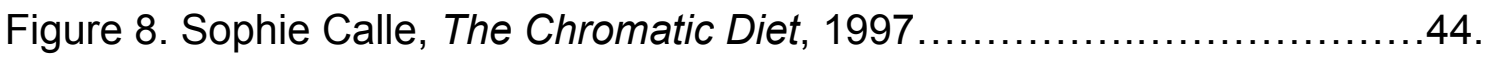

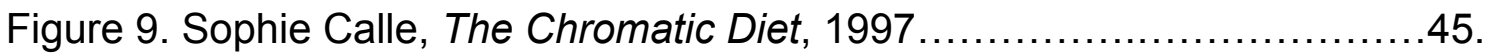

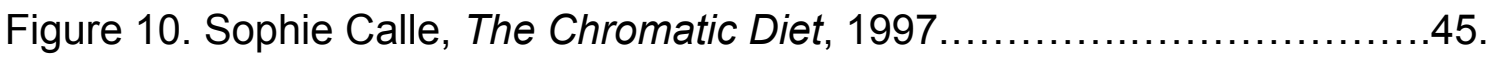

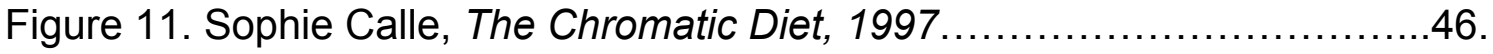

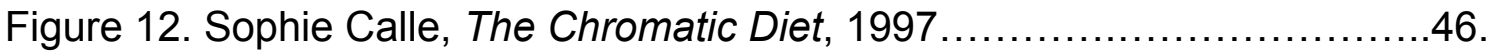

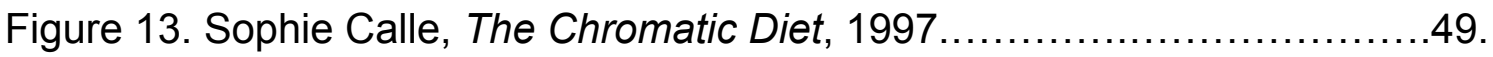

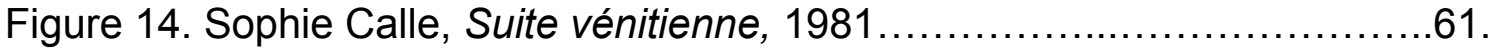

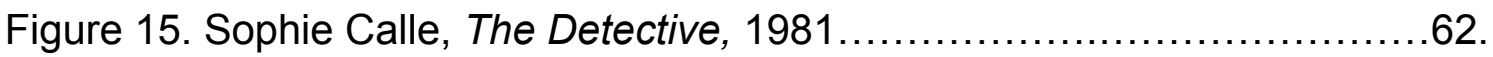

Figure 16. Carolee Schneemann, Interior Scroll, 1975 .......................65.

Figure 17. VALIE EXPORT, Action Pants/Genital Panic, 1969...................65.

Figure 18. Vito Acconci, Following Project, 1969.............................69.

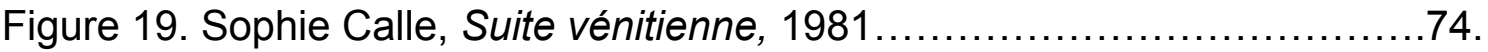

Figure 20. Sophie Calle, Paris Shadows, Excerpts from Calle's Diaries, 19781979. 74.

Figure 21. Sophie Calle, Detail, Suite vénitienne, and Detail, Paris Shadows..75. 
Figure 22. Hayley Newman, Crying Glasses: An Aid to Melancholia, 1995......85.

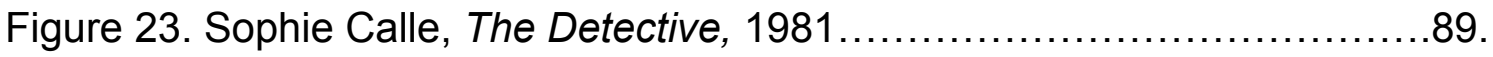

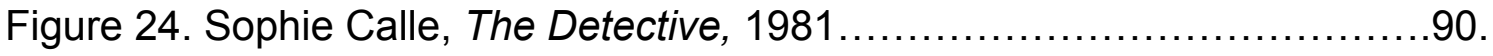

Figure 25. Sophie Calle, The Detective, $1981 \ldots \ldots \ldots \ldots \ldots \ldots \ldots \ldots \ldots \ldots \ldots \ldots 1$.

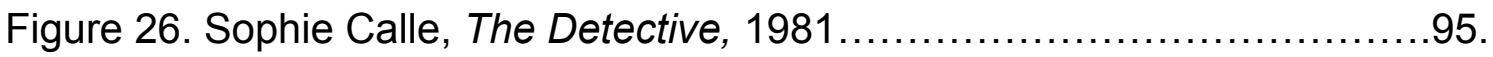

Figure 27. Sophie Calle, The Birthday Ceremony, 1980-1993...................99.

Figure 28. Sophie Calle, The Birthday Ceremony, 1980-1993.................104.

Figure 29. Sophie Calle, The Birthday Ceremony, 1980-1993.................104.

Figure 30. Sophie Calle, Days Under the Sign of B, C and W, 1998_.........114.

Figure 31. Sophie Calle, Days Under the Sign of B, C and W, 1998.........115.

Figure 32. Sophie Calle, Des journées entières sous le signe $d u B, d u C$, du W, 1998.

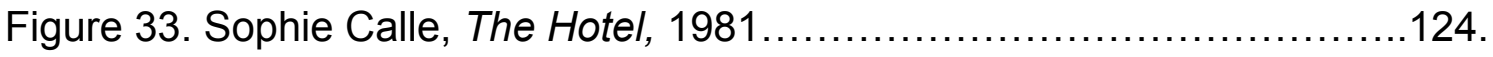

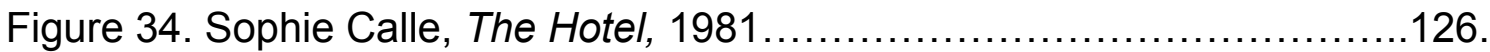

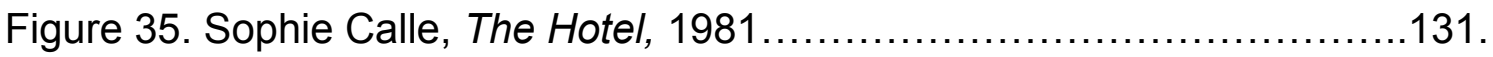

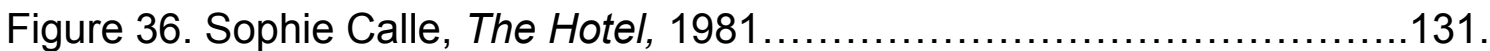

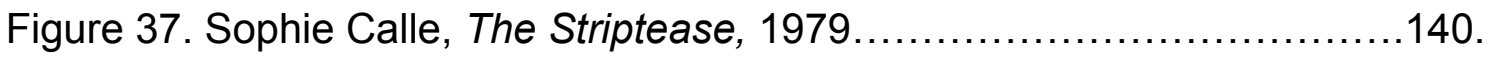

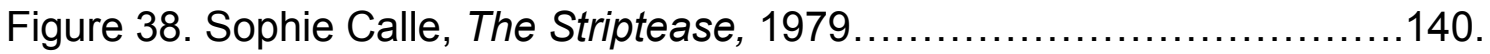

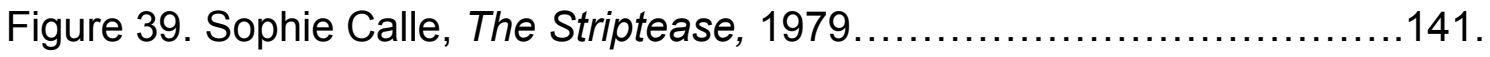

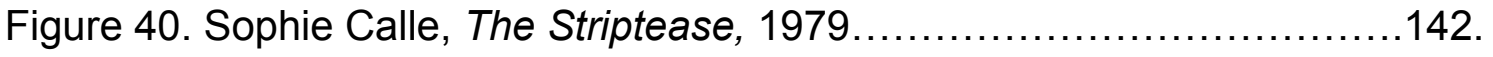

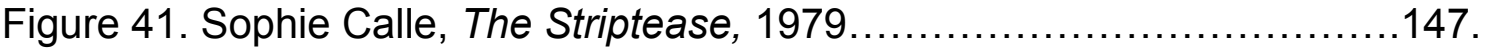

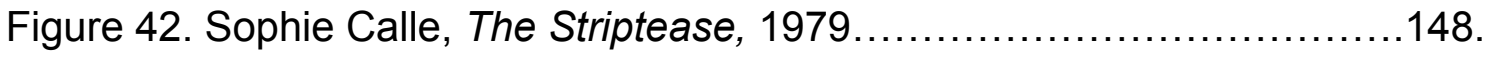

Figure 43. Sophie Calle, La lame de rasoir, Des histoires vraies, 1994_.......157. 
Figure 44. Pierre Baudry, Letter to the Editor, Libération. 159.

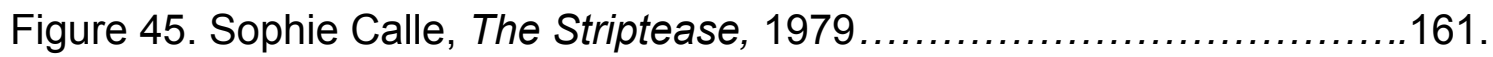

Figure 46. Paul Auster, Letter to Sophie Calle, 1994_........................167.

Figure 47. Paul Auster, Personal Instructions for S.C. on How to Improve Life in New York City (Because she asked...)........................................168.

Figure 48. Sophie Calle, Gotham Handbook, 1994............................175.

Figure 49. Sophie Calle, Gotham Handbook, 1994.............................178.

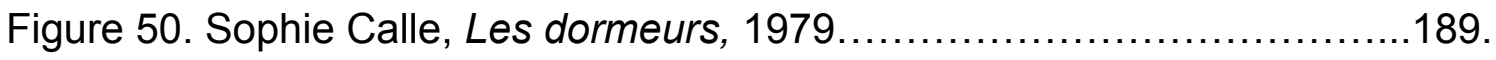

Figure 51. Sophie Calle, Gotham Handbook, 1994.............................191.

Figure 52. Sophie Calle, Gotham Handbook, 1994.............................192.

Figure 53. Sophie Calle, Gotham Handbook, 1994.............................196.

Figure 54. Sophie Calle, The Wardrobe, 1985-1992 _........................203.

Figure 55. Sophie Calle, The Wardrobe, 1985-1992 .........................203. 


\section{INTRODUCTION: LIKE IN A THESIS}

It's true that when I speak in public, everyone asks me about life and I always have to bring them back to the fact that it's a work of art. The difference with many of my works is the fact that they are also my life. They happened. ${ }^{2}$

You know, it's not about telling my life, it's not about telling you truth. It's not the truth, obviously. It happened, but it's not truth. ${ }^{3}$

\section{Double Game}

Double Game, published in 1999 by Violette Editions, is an account of the projects and interaction of French contemporary artist Sophie Calle with American author Paul Auster. In 1992 Paul Auster borrowed eight of Calle's projects for Maria, a fictional character in his novel Leviathan, and added two of his own invention. Calle then borrowed these two additional projects authored by Auster, performed, documented, and included them in her book(s). Double Game is thus divided into three parts: "The life of Maria and how it influenced the life of Sophie Calle;" "The life of Sophie Calle and how it influenced the life of Maria;" and finally, "One of the many ways of mingling fact and fiction, or how to try to become a character out of a novel." ${ }^{4}$ The last section contains only one project, Gotham Handbook, a project that Calle asked Auster to author for her alone.

Double Game is not an exhibition catalogue, yet it is not a work of art distinct from any exhibition, for the eleven projects included in Double Game were initially exhibited together in Calle's French solo exhibition, Doubles-jeux, at the Centre National de la Photographie in Paris (1999). However, there is no

\footnotetext{
${ }^{2}$ http://www.egs.edu/faculty/sophie-calle/biography/

${ }^{3}$ Sophie Calle, "Interview with Shelia Heti," The Believer (June 2012): 49.

${ }^{4}$ Sophie Calle with the participation of Paul Auster, Double Game (London: Violette Editions, 1999), 2-3.
} 
mention of this exhibition in Double Game. At the same time as the initial exhibition, these projects were published by Actes Sud, in French only, as a boxed set of seven books under the same name as the exhibition: Doublesjeux. ${ }^{5}$ This compendium of all eleven projects, published in English only, is a recontextualization and translation of these same projects, which date from 19811999. ${ }^{6}$

Most of Calle's projects are published in book form, yet there is very little written about her books. Only a few writers have addressed the relationship between the book and the work when it is exhibited, most notably Yve-Alain Bois who states: "I don't think that her installations are that interesting per se. I think that they are expanded books. Basically, I see her as a writer. I told that to her, I said, 'Why do you need to do those big blow-ups of those things?'

Because as books, they are fantastic things. I think she is a great story-teller, among other things." ${ }^{7}$ Calle is first and foremost, a storyteller, but a storyteller whose autofictional accounts are always based on the events of her life... or in the case of Double Game, the events of the fictional life of Maria. This interplay between Calle and Maria is already acknowledged by the photograph on the cover of Double Game, which features a woman (Calle) wearing a blonde wig

\footnotetext{
${ }^{5}$ In the French boxed set there are seven books: I) De l'obéissance contains both of Auster's projects that he created for Maria: Le régime chromatique, Des journées entières sous le signe $d u B, d u C$, du W; II) Le rituel d'anniversaire; III) Les panoplies contains both La garde-robe and Le stip-tease; IV) A suivre... contains Préambule, Suite vénitienne, and La filature; V) L'hôtel; VI) Le carnet d'adresse; VIII) Gotham Handbook: New York, mode d'emploi.

6 "Suite vénitienne was translated from the French by Dany Barash and Danny Hatfield and first published in English in 1988 by Bay Press Seattle. Additional translation by Charles Penwarden, Paris." Sophie Calle, Double Game, Copyright Page.

${ }^{7}$ Yve-Alain Bois, "In Conversation: Rosalind Krauss and Yve-Alain Bois," The Brooklyn Rail: Critical Perspectives on Arts, Politics and Culture, February $1^{\text {st }}, 2012$. http://www.brooklynrail.org/2012/02/art/rosalind-krauss-with-yve-alain-bois (accessed August $19,2013)$. Bois is referring to her installation of Take Care of Yourself at the Venice Biennale (2007), and then later installed at the Bibliothèque Nationale in Paris.
} 
and a blue negligée, sitting in bed. Two butterflies are adhered to the wall and around her neck sits a dead cat (figure1). There are no words on the cover, only a burgundy satin ribbon that, like a diary, must be untied to open the book. ${ }^{8}$

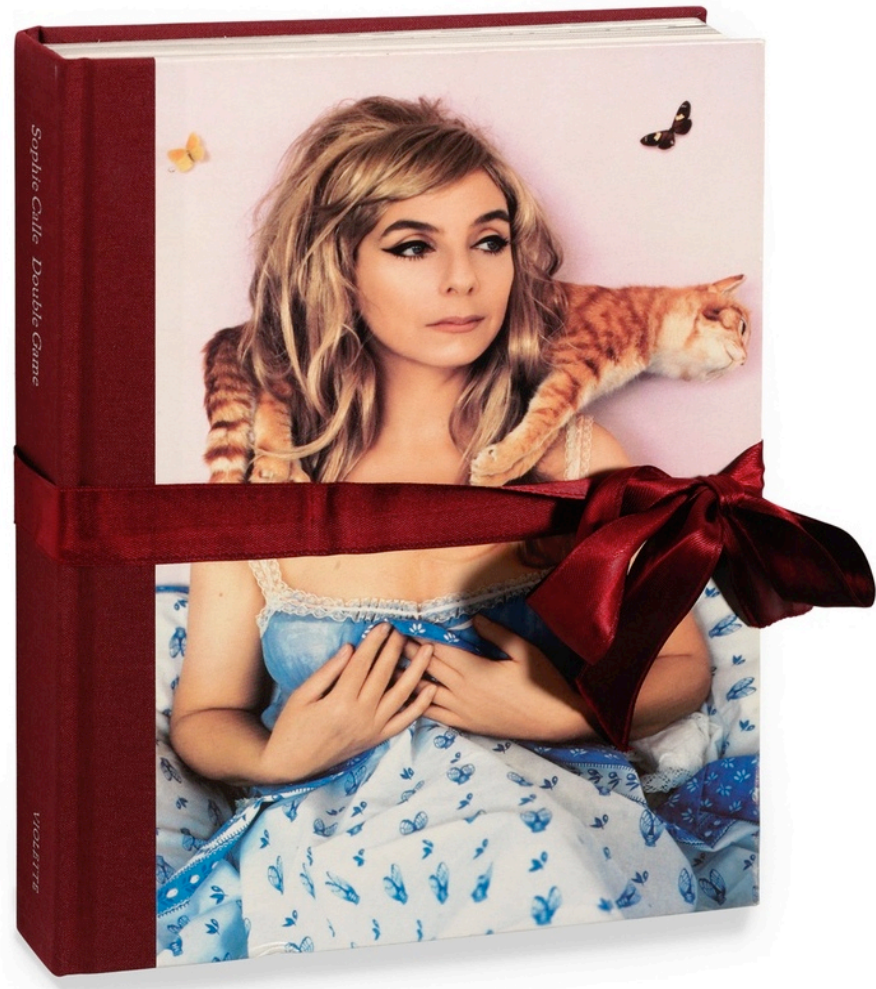

Figure 1. Sophie Calle (with the participation of Paul Auster), Double Game (London: Violette Editions, 1999).

Source: Violette Editions

After untying the ribbon and opening the compendium, we find that this book resembles many other books: numbered pages organized into different

\footnotetext{
${ }^{8}$ Eye magazine writes: "In 1999, French artist Sophie Calle teamed up with Violette Editions to produce the extraordinary Double Game, a monograph comprising a digest of Calle's most celebrated work to date, including a then recent collaboration with author Paul Auster. Beautifully and inventively designed by Vince Frost, it came wrapped like a present with a lush satin ribbon and large-format pages interspersed with pocket-sized paperback pages from Auster's novel, Leviathan. It was that rare thing, an artist's monograph that was actually a work of art in and of itself, a furthering of Calle's vision rather than 'just' another exhibition spin-off." "Review: Emotional baggage and the art of Freud's soft furnishings," EYE Magazine: The International Review of Graphic Design 57 (Autumn 2005). http://www.eyemagazine.com/review.php?id=124\&rid=592 (accessed Feb, 28, 2012)
} 
sections, which are clearly articulated by the Table of Contents. The pages of each project resemble the other pages of the project-photos and text arranged, grid-like on the page, repeated. There are, however, a few deviations to this formula: To Follow... one of Calle's early projects, consists of only three pages which are photographs of pages from Calle's diary; there is a letter from Auster; as well as two inserts, printed on smaller pages that resemble the pages from a paperback novel.

The first insert, printed on a single smaller piece of paper is the copyright page. On the first side there is the copyright information for Double Game, and circled in red: "The author extends special thanks to Paul Auster for permission to mingle fiction with fact" (figure 2). And on the verso there is the copyright information from Auster's novel Leviathan, and also circled in red: "The author extends special thanks to Sophie Calle for permission to mingle fact with fiction" (figure 3). 


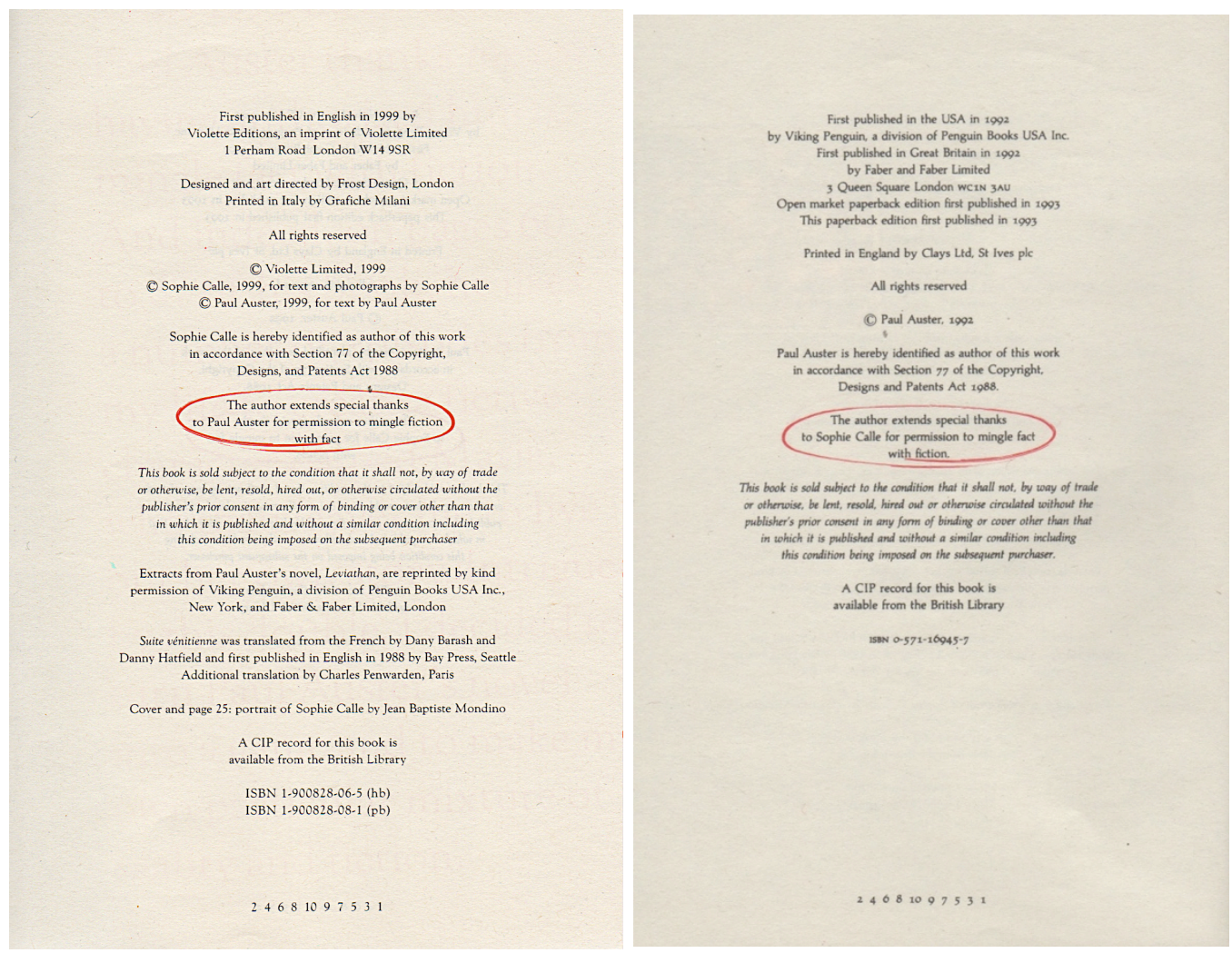

Figure 2. Calle, Double Game, Copyright Page.

Figure 3. Paul Auster, Leviathan (London and Boston: Faber and Faber, 1992), reprinted in Double Game, Copyright Page.

Immediately following this insert, we are presented with the premise of this book:

The Rules of the Game: In his 1992 novel Leviathan, Paul Auster thanks me for having authorized him to mingle fact with fiction. And indeed, on pages 60 to 67 of his book he uses a number of episodes from my life to create a fictive character named Maria, who then leaves me to live out her own story. Intrigued by this double, I decided to turn Auster's novel into a game and to make my own particular mix of reality and fiction. ${ }^{9}$

Double Game brings together text and photographs and Calle's play between textuality and visuality asks that we question the relationship between

\footnotetext{
${ }^{9}$ Calle, Double Game, 1.
} 
these differing modes of representation as she plays with the boundaries between art and life, fact and fiction. The projects included in Double Game recount birthday rituals, her job as a chambermaid and a striptease artist, as well as notes and photographs from a private detective whom she asked her mother to hire to follow her for a day—projects that seemingly document her life. But in looking closely at these works contradictions, fictions, and omissions are exposed. For example, the account from the detective and Calle's account of her activities for the day contradict each other.

Calle's work consistently plays with our understanding of truth, teasing and taunting the reader by using forms and genres associated with truth-telling: "autobiography," the diary, the report, the bureaucratic file, letters, and photographs. Double Game presents us with an archive that seems to provide (and produce) evidence and traces of the events described. However, we are always in doubt about the events narrated as the textual and visual descriptions do not always correspond; we are never sure what "really happened." Calle challenges the authority of these documents that she exhibits and publishes by pointing out—or letting us discover in our role as reader/detective/archivist—the gaps, the absences, and the fictions. Calle's work asks that we consider more intently the relationship between doing, saying and seeing.

\section{Autofiction}

Autofiction is the lens through which I consider Calle's archival traces. Autofiction is a literary term, coined by French writer Serge Doubrovsky in the preface to his first novel Fils (1977), to describe a literary work in which the 
author, the protagonist, and the narrator share the same name, like autobiography. Autofiction, however, is considered a hybrid practice situated somewhere between autobiography (conceived of as truth) and the novel (as fiction); autofiction is considered to offer a more deliberate and self-conscious play between the two. ${ }^{10}$

Autofictional narratives like Calle's and Auster's work against the conventional literary model of life-writing dictated by Philippe Lejeune in The Autobiographical Pact (1975) in which Lejeune insists on the existence of a pact between the reader and the intratextual narrator, protagonist and author of the work. ${ }^{11}$ Lejeune insists that autobiography and biography, unlike fiction, are "referential texts: exactly like scientific or historical discourse, they claim to provide information about a 'reality' exterior to the text... Their aim is not simple verisimilitude, but resemblance to the truth." ${ }^{12}$ Autofiction is thus often characterized as a double contract between the reader and the narrator/author/ character, demanding the author tell the truth about her life, yet understanding that there is always space for invention. Autofiction's appeal lies in the unresolvable paradox of these "contradictory reading instructions."13

\footnotetext{
${ }^{10}$ Autofiction has been theorized and discussed most notably by Serge Doubrovsky, Philippe Lejeune, Philippe Gasparini, Marie Darrieeussecq, Johnnie Gratton, Elizabeth Jones, Marion Sadoux, Shirley Jordan, Frank Zipfel and Claire Boyle. Its appeal can be seen by more recent publication of journals devoted entirely to autofiction: Parachute Magazine published an issue on autofiction in 2002; Image [\&] Narrative published two issues on the subject in 2007; and a new journal Auto/Fiction had its inaugural issue published in July 2013. There is also a web site dedicated to writing about autofiction (autofiction.org).

${ }^{11}$ Philippe Lejeune, "The Autobiographical Pact," On Autobiography, trans. Katherine Leary (Minnesota: University of Minnesota Press, 1989).

12 Lejeune, "The Autobiographical Pact," 22.

${ }^{13}$ Frank Zipfel, "Autofiction," Routledge Encyclopedia of Narrative Theory, eds. David Herman, Mandfred Jahn (New York and London: Routledge, 2007), 37.
} 
Rather than build up autofiction in opposition to autobiography, however, I suggest that autofiction helps problematize autobiography, which is still considered a more coherent and stable form of narration. ${ }^{14}$ Throughout my dissertation I stress the undecideability of Calle's texts and photographs. For Jacques Derrida, undecideability is associated with words like ghost, pharmakon, hymen, etc., something that cannot conform to either polarity of a dichotomy (presence/absence, cure/poison, inside/outside, and fact/fiction). By focusing on the contingency of Calle's autofictional traces and the ambiguous status of the represented events, I link the uncertainty of Calle's work not only to Derrida's concept of undecideability, but also to play and mobility, as the subject of autofiction continually announces it "is 'l'", and "not 'l', simultaneously.

I do not pretend that autofiction is without debate, for autofiction's relationship to autobiography is not always clear, especially as autobiographical studies begin to acknowledge the role of fiction and performativity in what Lejeune would term "autobiography." In fact, Paul de Man suggests that autobiography "lends itself poorly to generic definition; each specific instance seems to be an exception to the norm." ${ }^{15}$ De Man addresses this overaccentuated distinction between autobiography and fiction that reoccurs within theories of autobiography and suggests that, "autobiography seems to depend on actual and potentially verifiable events in a less ambivalent way than fiction does. It seems to belong to a simpler mode of referentiality, of representation,

\footnotetext{
${ }^{14}$ Phillippe Gasparini, "Autofiction vs Autobiography," Auto/Fiction 1, no. 1 (July 2013): 7.

${ }^{15}$ Paul De Man, "Autobiography as De-facement," MLN 94, no. 5 (Dec, 1979): 920.
} 
and of diegesis." ${ }^{16}$ The relationship between autobiography and fiction is already ambiguous. As Marian Sadoux articulates, the hesitation around autofiction lies in the binary opposition of "reality-truth versus fiction." ${ }^{\text {"17 }}$ In Sadoux's words: "To define autofiction as either a fictional autobiography or as the first person narration of events belonging to the fictional life of an author/character who shares a name with the author, clearly leads to difficulties." ${ }^{18}$ These difficulties return us to the slipperiness of the terms fact and fiction—a slipperiness I propose Double Game accentuates.

Literary critic Johnnie Gratton, who has written extensively on Sophie Calle's work, clearly positions the uncertain status of her documents:

By constantly making us unsure about the face value of her textual and photographic statements, Calle seems to encourage in those who read and view her work a sense of its own incipient fictionality, even where its most overt claims are documentary or, in photographic terms, indexical. At the same time, however, it continues to sound as though it could still be 'true'; the effect of truth, whether autobiographical or ethnographic in its generic force cannot be cancelled out. We are thus left suspended, uncertain. ${ }^{19}$

Sadoux has argued that one of the important features of autofiction is its ability to "cultivate a diverse element of doubt around the apparently autobiographical events narrated. ${ }^{20}$ As I will demonstrate, the documents included in Double

\footnotetext{
${ }^{16}$ De Man, "Autobiography as De-facement," 920.

${ }^{17}$ Marian Sadoux, "Angot's Autofictions: Literature and/or Reality?," in Women's Writing in Contemporary France: New Writers, New Literature in the 1990s, eds. Gill Rye and Michael Worton (Manchester and New York: Manchester University Press, 2002), 175.

${ }^{18}$ Sadoux, "Angot's Autofictions: Literature and/or Reality?," 175.

19 Johnnie Gratton, "Experiment and Experience in the Phototextual Projects of Sophie Calle," in Women's Writing in Contemporary France: New Writers, New Literatures in the 1990s, eds. Gill Rye and Michael Worton (Manchester and New York: Manchester University Press, 2002), 159.

${ }^{20}$ Sadoux, "Angot's Autofictions: Literature and/or Reality?," 175.
} 
Game—both text and photographs—continually point to the gap between what may have happened, and what is said or shown to have happened.

\section{Autofiction and Theory (poststructuralism)}

In Calle's work I stress the ways in which autofiction blurs genres and accentuates play, offering greater possibilities for a decentred subject. My employment of the subject throughout my dissertation relies on a poststructuralist, post-Lacanian understanding. The subject is understood to be an unstable signifier, and always already divided. Throughout Double Game I explain how Calle's work exploits the fiction that underlies the fantasy of plentitude and selfhood associated with the subject and instead foregrounds plurality and fragmentation. While I don't explicitly link Calle's work to the interplay between lack and desire, it is understood to be a vital component of my understanding of her work, which I claim problematizes a unified, stable and self-determining subject. This understanding of the subject comes to bear on her work in a literal way as she consistently moves between subject positions.

The sense of play and mobility offered the "autobiographical" subject by autofiction is re-articulated by Gill Rye and Michael Worton, who propose that the movement between the autobiographical and the fictional offers a plethora of possibilities for the writing and speaking subject, "characterized by its mobility." ${ }^{21}$ Autofiction thus opens a greater space for possibility and plurality.

\footnotetext{
${ }^{21}$ Gill Rye and Michael Worton, "Introduction," in Women's Writing in Contemporary France: New Writers, New Literature in the 1990s, eds. Gill Rye and Michael Worton (Manchester and New York: Manchester University Press, 2002), 9. Shirley Jordan, along with Marian Sadoux, argues that the play and slippage between life and art, author and subject is a way for women to not only experiment with self-representation, but also allows for distance in writing about trauma and pain. Calle's work has received some attention in this area, particularly Prenez soins de vous (2007) and Douleur exquise (1984-2003) which deal directly with loss,
} 
Leigh Gilmore writes: “Western autobiographical practices flourished because there seemed to be a self to represent, a unique and unified story to tell that bore common ground with the reader, a mimetic medium for selfrepresentation that guaranteed the epistemological correspondence between narrative and lived life."22 Autofiction thus disrupts an understanding of the self and of the self in autobiographical accounts as indivisible and unitary, and works to destabilize any fantasy of stable subjectivity. Fragmentation, discontinuity, and a self-conscious, often theoretical, reflexivity mark autofiction. Philippe Gasparini claims that autofiction creates a space " to build up a dialectic relationship between self-writing and criticism." ${ }^{23}$ Thus the double writing associated with autofiction can also be seen in the ways that the author merges literary theory with the practice of autobiographical writing. The "I" invoked through writing is continually questioned through textual deconstruction of the subject; a subject that on the one hand "drift[s] towards the first person and towards autobiography and, secondly, a theoretical questioning on [sic] the relationship between two previously distinct fields: those of fiction and autobiography." ${ }^{24}$

European scholar Joost de Bloois argues that autofiction itself can be situated between theoretical discourse (poststructuralism specifically), and

disappointment and mourning. Shirley Jordan writes, "A key practitioner of specifically feminine autofictional practice, Calle powerfully explores vulnerability, returns magnetically to paradigmatic experiences of disappointed love, and defines her work as therapeutic - a way of 'taking care of herself '." Shirley Jordan, "État Présent: Autofiction in the Feminine," French Studies, LXVII, no. 1 (2012): 82.

${ }^{22}$ Leigh Gilmore, Autobiographics: A Feminist Theory of Women's Self-Representation (Ithaca and London: Cornell University Press, 1994), 17.

${ }_{23}$ Gasparini, "Autofiction vs Autobiography," 5.

${ }^{24}$ Karen Ferreira-Meyers, "Historical Overview of a New Literary Genre: Autofiction," Auto/Fiction 1, no. 1(2013): 23. 
artistic practice--"the work-of-art-as-theory." ${ }^{25}$ Bloois writes that this "doublecrossing" of both aesthetic and theoretical concerns, which begins in literary theory and practice in the 1960 s, carries over into visual work such as conceptual art. Bloois' essay attempts to situate autofiction within visual practice by arguing that art of the late $60 \mathrm{~s}, 70 \mathrm{~s}$, and 80 s shared, among other things, a propensity for accentuating the overlap between conceptual art, performance art, and documentation, all of which I stress in my discussions of Calle's autofictional work. ${ }^{26}$ This linkage between the event and its representation seems even more critical today in an era of social media and digital mediation, where documentation and representation seem to have exchanged places with the live, body-to-body experience. ${ }^{27}$

\section{Roland Barthes}

For Bloois, and for my thesis-Chapter One in particular-it is Roland Barthes who emerges as an important figure. ${ }^{28}$ According to Bloois, Roland Barthes by Roland Barthes (1977) "systematically explores the porosity of the boundaries

\footnotetext{
${ }^{25}$ Joost de Bloois, "The artists formerly known as... or, the loose end of conceptual art and the possibilities of 'visual autofiction'," Image [\&] Narrative [e-journal] 19 (2007) http://www.imageandnarrative.be/autofiction/debloois.htm (Accessed May 15, 2011) ${ }^{26}$ See Image [\&] Narrative's Special Issues on Autofiction. See also Diane Watteau who argues that the notion of autofiction remains pertinent in contemporary art today. Watteau discusses Sophie Calle briefly, along with Sylvie Blocher, Gillian Wearing, Clarisse Hahn, and Véronique Aubouy and situates autofiction as their interplay between real life stories and visual media. Diane Watteau, "L'Autofiction, une vocation suspendue dans l'art contemporain?: Les $<<$ moi en toc>> et les <<trou d'être>> de Serge Doubrovsky," L'Esprit Créateur 49, no. 3 (Fall 2009): 115132.

${ }^{27}$ Here I think of social media networks such as Facebook, online learning courses, immersive environments, and even "live" performances like that of Tupac at Coachella in 2012. See also Phillip Auslander, Liveness: Performance in a Mediatized Culture (New York and London: Routledge, 2008).

${ }^{28}$ Gill Rye, and Michael Worton also stress the importance of Roland Barthes in relation to autofiction. See Gill Rye and Michael Worton, "Introduction," in Women Writing in Contemporary France: New Writers, New Literatures of the 1990s, eds. Gill Rye and Michael Worton (Manchester and New York: Manchester University Press, 2002).
} 
between theoretical prose, fiction and autobiographical (if not, therapeutic) problematics." ${ }^{29}$ Roland Barthes by Roland Barthes helps us understand this precarious relationship between truth, authenticity, and representation by making clear in its title that the Roland Barthes that writes is different from the Roland Barthes represented (hence the double referent): "I am writing a text and I call it R.B." ${ }^{30}$ Barthes insists that we read his "autobiography" "as if told by a character in a novel." ${ }^{31}$ The double referent is in direct opposition to Lejeune, who equates the author of the text with the author in the text. ${ }^{32}$ This unification, as De Man has articulated, folds a "specular" structure into a single subject, no longer mirror-like. ${ }^{33}$

In my efforts to unpack the significance of Calle's autofictional gestures and traces in Double Game, I frame her work through poststructuralist understandings of repetition and difference, as the same but not identical. According to Derrida, every sign "linguistic or non-linguistic, spoken or written (in the current sense of this opposition) in a small or large unit can be cited, put between quotation marks; in so doing it can break with every given context, engendering an infinity of new contexts in a manner which is absolutely illimitable." ${ }^{34}$ I attempt to elaborate on how the projects in Double Game rely on reiteration, as the same but not identical.

\footnotetext{
${ }^{29}$ Bloois, "The artists formerly known as... or, the loose end of conceptual art and the possibilities of 'visual autofiction'," (Accessed May 15, 2011).

${ }^{30}$ Roland Barthes, Roland Barthes by Roland Barthes, trans. Richard Howard (New York: Hill and Wang, 1977), 56.

${ }^{31}$ Barthes, Roland Barthes by Roland Barthes title page.

32 De Man, "Autobiography as De-facement," 923.

33 De Man, "Autobiography as De-facement," 923.

34 Jacques Derrida, "Signature Event Context," in Margins of Philosophy, trans. Alan Bass (Chicago: University of Chicago Press, 1982), 12.
} 
The genealogy of autofiction is one that parallels the rise of poststructuralism and has been discussed by a number of writers, most notably by Anneleen Masschelein, Joost de Bloois and Marion Sadoux. In his definition of autofiction for the Routledge Encyclopedia of Narrative Theory, Frank Zipfel writes that autofiction "highlights the constructed, creative and fictional character of all (autobiographical) narration, the eradication of the difference between fact and fiction, the questioning of the common distinction between art and life, and the collapse of the concept of a homogeneous, autonomous subject identity. ${ }^{35}$ Most of these writers who align autofiction with poststructuralism accentuate both the death of the subject and of the author.

However, Christine Macel in her catalogue essay for Calle's retrospective at the Centre Pompidou (2007) contends that Calle's work, in general, writes against the death of the author, arguing that her work gained momentum in France at the same time poststructuralism was experiencing a decline ${ }^{36}$ Conversely, I propose that Calle's work engages poststructuralism in a way that demonstrates the fraught relationship between autobiographical acts and self-representation—one in which an overtly fragmentary and fictional subject emerges. Rather than a complete annihilation of the author, I propose that Calle's projects are more playful in their authorial games. I contend that Double Game, in keeping with autofiction, continually constructs and deconstructs Sophie Calle the author and subject of her projects. Calle's authorial games extend into her collaboration with Paul Auster.

\footnotetext{
${ }^{35}$ Zipfel, "Autofiction," 37.

${ }^{36}$ Christine Macel, "The Author Issue in the Work of Sophie Calle. Unfinished," in Sophie Calle, M'as-tu vue? (Munich, Berlin, London, New York: Prestel, 2003), 17.
} 


\section{Paul Auster}

Auster is well known for the planting of autobiographical traces within his novels, which often blend the detective crime novel with what has been described as a metaphysical or postmodern search for identity. For example at the beginning of City of Glass (1985), the first novel in his famous New York Trilogy, the narrator, Daniel Quinn, receives a phone call from someone asking if he is "Paul Auster. Of the Auster Detective Agency." Intrigued, Quinn looks up Paul Auster in the phone book and arranges a meeting:

"I'm sorry to disturb you," Quinn apologized. "But l'm looking for Paul Auster." "I'm Paul Auster," said the man.

"I wonder if I could talk to you. It's quite important."

"You'll have to tell me what it's about first."

"I hardly know myself." Quinn gave Auster an earnest look.

"It's complicated, I'm afraid. Very complicated."

Later when Quinn asks if he is the detective Paul Auster, Auster responds:

"I'm afraid you've got the wrong Paul Auster."

"You're the only one in the book."

"That might be," said Auster. "But l'm not a detective."

"Who are you then? What do you do?"

"I'm a writer."38

Even in Leviathan, Peter Aaron, the narrator, is a new writer who has returned to the United States from France and makes his living by translating books. Aaron's life echoes Auster's own life: Auster also lived in France and upon returning to America made his living translating books. The initials even match: PA. But as the publisher's note in Leviathan makes clear: “...any resemblance to actual persons, living or dead, events, or locales is entirely

\footnotetext{
${ }^{37}$ Paul Auster, City of Glass (New York and London: Penguin Books, 1985), 111.

${ }^{38}$ Ibid., 113.
} 
coincidental." ${ }^{39}$ This seems a fitting start to a book that self-consciously plays with its construction of authorship. In Double Game the interplay between Calle and Auster culminates in Gotham Handbook where Auster authors Calle's actions.

\section{Autofiction and Performance Archive (the event and its traces)}

My dissertation aligns Calle's projects with performance, and I suggest that Double Game exists as a repository for the documents associated with Calle's durational projects. What develops is a more focused consideration of the relationship between the event and its remains. The documents contained within Double Game act as an index of Calle's autobiographical acts, as marks or traces of these occurrences; but her documents also draw attention to the possible invention of the event, and/or often expose the fabrication of her documentation. As Phillip Auslander has so clearly articulated, the "traditional assumption of performance documentation resides in its indexical relationship to the event it documents. In this view, performance documentation provides both a record of the event through which it can be reconstructed and evidence that it actually occurred." ${ }^{40}$ Autofiction proves useful in helping us rethink and reposition documentation in relation to the event; as Amelia Jones has argued: "There is no singular, authentic or original act we can refer to in order to confirm the true meaning of an event, an act, a performance, or a body—presented in

\footnotetext{
${ }^{39}$ Paul Auster, Leviathan (New York and London: Penguin Books, 1992), copyright page.

${ }^{40}$ Phillip Auslander, "Towards a Hermeneutics of Performance Art Documentation," in Lessons in the Art of Falling: Photographs of Norwegian Performance and Process Art 1966- 2009, ed. Jonas Ekeberg (Horten, Norway: Preus Museum, 2009), 93.
} 
the art realm or otherwise. ${ }^{41}$ Calle's performance documentation accentuates the ways in which we know (or do not know) and speaks more broadly to archival hermeneutics, opening the archive to play and interpretation. This tension between what is shown and what is not shown, what is said and what is not said is, at least according to Matthew Reason, the "dilemma of documentation." ${ }^{42}$

In employing the structures and operations of the archive, Calle's collection of documents, on the one hand, appear to complete, close, and authenticate the experiences described; while, on the other hand, they are that which threatens the order and authority of the archive itself. By revealing the possible fictionality of the event and its narration, as well as the uncertain status of the photographs, Calle's work undermines the authority of her own archival impulse.

In his 1994 essay, "An Archival Impulse," critic Hal Foster identified what he considered a trend in contemporary art at the time which focused not only on the production of archives, but also used a "quasi-archival" logic and structure to highlight the tensions (and significance) of archives as "found yet constructed, factual yet fictive, public yet private." ${ }^{.43}$ "Further, it [the work] often arranges these materials according to a quasi-archival logic, a matrix of citation and juxtaposition, and presents them in a quasi-archival architecture, a complex

\footnotetext{
${ }^{41}$ Amelia Jones, "'The Artist is Present': Artistic Re-enactments and the Impossibility of Presence," TDR 55, no.1 (Spring 2011): 42.

${ }^{42}$ Matthew Reason, Documentation, Disappearance and the Reproduction of Live Performance (New York: Palgrave Macmillan, 2006), 27.

${ }^{43}$ Hal Foster, "An Archival Impulse," October 110 (Fall 2004), 4-5.
} 
of texts and objects...." ${ }^{44}$ The contradictory and fictional elements in Calle's work appear to nod towards Foster's own understanding of the double gesture of an archival/anarchival impulse, which he describes as "concerned less with absolute origins than with obscure traces. ${ }^{\not 4}$ Double Game explores this double impulse by playing with our expectations of what constitutes an archive, what is contained within that archive_or perhaps more importantly, what is absent from that archive- -and what authority it has in relation to its subject. ${ }^{46}$

Performance art has always had an unclear relationship to the archive, understood as a storehouse for documents and objects. As Reason makes clear: "Given the transience of live art, the live performance archive or museum is more problematic, as it by definition cannot contain actual performances-the thing itself is always absent." ${ }^{\prime 47}$ By default then, performance archives always already engage notions of absence and disappearance, highlighting the ephemeral quality of performance art. As Reason clearly articulates, performance, on the one hand, is understood to be actively resistant to representation; yet, on the other hand, it continues to have a "powerful preoccupation with documentation.. ${ }^{48}$ My discussion of Double Game as an archive of Calle's performative and autofictional acts considers the relationship

\footnotetext{
${ }^{44}$ Ibid., 5.

${ }^{45}$ Ibid., 4-5.

${ }^{46}$ There have been a number of recent texts which consider how the archive has been reconfigured and reinvigorated in contemporary art work and how this may be useful in opening up new discursive spaces for thinking about archives. See MIT/Whitechapel's The Archive (2006); Hal Foster's "An Archival Impulse" (2004), Okwui Enwezor's recent exhibit and catalogue essay, Archive Fever: Uses of the Document in Contemporary Art (2009); Sven Spieker's The Big Archive: Art and Bureaucracy (2008) and Deep Storage: Collecting, Storing and Archiving in Art which is both a catalogue as well as a collection of essays including essays by Benjamin Buchloh, Geoffrey Batchen, and Susan Buck-Morss.

${ }^{47}$ Reason, Documentation, Disappearance and the Reproduction of Live Performance, 36.

${ }^{48}$ Ibid., 231.
} 
and status of these documents, often fabricated, to the event and explores the productive and playful way in which Calle reconstitutes the events in the life of Sophie Calle (and the fictional Maria) within the pages of Double Game.

\section{Literature Review}

Paul Auster is widely known in both North America and France and over the last decade Sophie Calle has become a well-known International artist. Calle's retrospective at the Centre National d'Art et de Culture Georges Pompidou in 2002-2003 and her participation in the Venice Biennale in 2007 garnered her much enthusiasm and press. The publication of Sophie Calle, M'as-tu-vue? by the Centre National d'Art et de Culture Georges Pompidou brought together, for the first time, Calle's diverse body of work. ${ }^{49}$ The catalogue is organized around a number of themes that reoccur in Calle's work, which are also reflected in much of the writing about her projects: "shadows, investigations, vanishings," "hotel rooms, sleepless nights and other true stories," "games and ceremonies," "journeys," and "absence."

These themes are explored further in a collection simply titled Sophie Calle: The Reader, published in 2009, by the Whitechapel Gallery in London, England, in conjunction with a retrospective of her work. This collection brings together a number of diverse texts by theorists and art critics including Jean Baudrillard, Yve-Alain Bois, Lynn Cooke, Rosalind Krauss, and Robert Storr. ${ }^{50}$

\footnotetext{
${ }^{49}$ Along with annotated versions of Calle's projects, the catalogue contains three essays: Christine Macel, "The Author Issue in the Work of Sophie Calle. Unfinished;" Yve-Alain Bois, "Paper Tigress;" and Olivier Rolin, "Beet, Alfalfa, etc." Sophie Calle, M'as-tu-vue? Ed. Christine Macel (Munich, Berlin, London and New York: Prestel, 2002).

${ }^{50}$ Arranged chronologically, this collection starts with Baudrillard's "Please Follow Me" which discusses the theoretical implications of Calle's Suite vénitienne (1983) in which she shadows a man she just met, following him to Venice, and finishes with an "Index," written in 2009, by
} 
Like much of the writing about Calle's work, the focus tends to be broad and descriptive, bringing many of her projects into the discussion rather than focusing on a close reading of one or two projects. These essays, generally, discuss the blurring of life and art through Calle's tendency to make her private life (and the lives of others) public, and they often focus on her propensity to expose her "life" ${ }^{51}$ Her work is often framed as an exercise in chance, experiment, and game playing (Iwona Blazwick, Robert Storr, Yve-Alain Bois, Jean Baudrillard, Robert Pincus), or as a play between absence and presence-disappearance and erasure (Baudrillard, Blazwick, Pincus), and there is a strong focus on her voyeuristic tendencies, associated with witnessing, following, and detection (Baudrillard, Pincus, Storr, Linda Weintraub). This collection of essays enables me to identify some of the reoccurring themes that have evolved in art historical writing about Calle's work: themes of loss, absence, surveillance, ritual and ceremony, her unsettling of the boundaries between public and private, and her mingling of art and life.

Yet, despite almost every newspaper article, magazine article, and essay mentioning her play with "fact and fiction" or her propensity to "expose" the (supposed) intimate details of her life, there is surprisingly little analysis of this intersection of autobiography and fiction. Many reviews or discussions of

\footnotetext{
Andrea Tarsia which organizes Calles's work according to particular themes and subject matter ("angels, carnival, dérive, erotics, fiction, graffiti" etc.). There are, however, a number of important writers who are missing from this collection: Janet Hand, Marina Van Zuylun, Annie Richard, Johnnie Gratton, Michael Sheringham, Kate Ince, Shirley Jordan and Anne Sauvageot-who is the only person to have written a book on Calle-a taxonomy in dictionary form: L'art chaméléon (2007).

${ }^{51}$ For example, in Le Monde, Michel Guerrin described Calle as "une artiste française mondialement célèbre qui a fait de sa vie privée un thème centrale de son oeuvre." Michel Guerrin, "Sophie Calle: de la douleur comme un art," Le Monde, le 8 juin, 2007.
} 
Double Game seem to take the work at face value, an interplay between Auster's fiction and Calle's life, often noting the projects Auster borrowed and the ones he created for Calle, and suggesting Calle simply lives out Auster's character's life and vice versa. I attempt to bring some coherence and theoretical depth to the diverse collection of projects included in Double Game by focusing on undecideability, repetition, and difference as a way to demonstrate the impossibility of discerning Double Game's fact from fiction. Important to this discussion are Johnnie Gratton, Shirley Jordan, and Anneleen Masschelein who have specifically explored Calle's work in relation to autobiography and fiction. ${ }^{52}$ Michael Sheringham and Johnnie Gratton, more specifically, have given some attention to the discrepancies in Calle's work and why they might be important. In my dissertation I draw extensively on the work of both Johnny Gratton and Shirley Jordan as I frame Double Game as an autofictional archive and investigate the significance of Calle's reconstructions of her autofictional acts.

Calle's compendium has received mention by Yve-Alain Bois, Catherine Grant, Johnnie Gratton, and Rosalind Krauss, but only broadly and never in any depth. To date, there have been two masters' theses specifically on Double

\footnotetext{
52 Johnnie Gratton, "Sophie Calle's Des histoires vraies: Irony and Beyond," in Phototextualities: Intersections of Photography and Narrative, eds. Alex Hughes and Andrea Noble, 182-97 (Albuquerque: University of New Mexico Press, 2003); Shirley Jordan, "État Présent: Autofiction in the Feminine," French Studies, LXVII, no.1 (2012): 1-9; Anneleen Masschelein, "Can Pain Be Exquisite? Autofictional Stagings of Douleur exquise by Sophie Calle, Forced Entertainment and Frank Gehry and Edwin Chan," Image [\&] Narrative [e-journal] 19 (2007) http://www.imageandnarrative.be/autofiction/debloois.htm (Accessed May 15, 2011). See also Annie Richard, "La Famille autofictive de Sophie Calle," in Affaires de famille: The Family in Contemporary French Culture and Theory, eds. Marie-Claire Barnet and Edward Welch, 139-50 (Amsterdam: Rodopi, 2007).
} 
Game: my own Master's thesis, Authorial Turns: Sophie Calle and Paul Auster's Quest for Identity (2007), which considers Calle and Auster's intertextuality and their play with concepts of authorship in their respective works; and Kathleen Thibault's Doubles-jeux de Sophie Calle: Ie livre comme espace ludique, which considers the French version of Double Game in relation to games, play, and the role of the reader.

Of Calle's other works, Phantoms (1989-1991), Les Aveugles (1986), L'Erouv de Jerusalum (1996), Douleur exquise (1984-2003) and Prenez soins de vous (2007), initially shown at the Venice Biennale, have perhaps garnered the most critical attention. In these projects Calle creates a collection/archive of memories and/or interpretations of events, objects or ideas around something lost or absent. In Phantoms, Calle replaces stolen paintings at the Isabella Stewart Gardner Museum in Boston with descriptions and memories of the missing works of art. In Les Aveugles, Calle asks blind people to define beauty. These descriptions are accompanied by photographs taken by Calle that seemingly represent the oral descriptions; when exhibited there is the text, the image taken by Calle, along with a portrait of the individuals. For L'Erouv de Jerusalem, Calle asked people in Israel, both Palestinians and Israelis, to take her to a public space that they consider private and to share their associations. And, in Douleur exquise, she recounts a painful breakup, repeating and remembering her experience over one hundred days until it fades away. My reading of Calle's documents as autofictional remains looks at absence through a different lens: one less focused on psychoanalytic forms of nostalgia, 
mourning, and memory, but concerned instead with the ways that absence, gaps, and omissions might highlight certain tensions between what is enacted, what is written, and what is photographed. ${ }^{53}$

With respect to Double Game, it is Calle's following projects (To Follow..., The Detective, and Suite vénitienne), along with The Hotel, which have been written about extensively. Most well known perhaps is Jean Baudrillard's essay “Please Follow Me," which accompanied Calle's Suite vénitienne, her first published book in 1983. Baudrillard suggests that Calle's pursuit of Henri B (the man she follows in Venice) is linked not only to seduction, "to follow someone but not to approach them," but also disappearance, like a shadow. Baudrillard links "this act of disappearance" to photography which "captures the other vanished in front of the lens, which preserves him vanished on film, which, unlike a gaze, saves nothing of the other but his vanished presence." ${ }^{54}$

Whitney Chadwick also explores Calle's Suite vénitienne in connection with following, seeing and being seen, as well as desire by comparing it to André Breton's Nadja (1928), which, like Calle's Suite vénitienne, also takes the form of a diary accompanied by photographs. In Nadja, the protagonist, André, recounts his brief affair with a woman, an uncanny figure whom he encounters by chance on the streets of Paris, only to question his own desire/construction.

\footnotetext{
${ }^{53}$ This way of thinking about absence seems to be aligned with Foster's understanding of the archival impulse in works of art produced in the mid-nineties. Foster suggests that archival work produces "construction sites" rather than "excavation sites," and thus represents a shift away from the melancholic cultural practices of the 1990s that treated "the historical as little more than traumatic." Foster, "An Archival Impulse," 22.

${ }^{54}$ Jean Baudrillard, "Please Follow Me," reprinted in Sophie Calle: The Reader (London: The Whitechapel Gallery, 2009), 25.
} 
This construction of desire for the person being followed is also repeated in Calle's work: "I must not forget that I don't have any amorous feelings toward Henri B. ${ }^{, 55}$

In her article, "Desiring to be Led Astray," Emma Cocker aligns Calle's Suite vénitienne with Surrealist strategies of errance, aimless wandering, extending this lineage to post-war French practices such as the Situationists, and the dérive. Cocker suggests that in Suite vénitienne, Calle's following and repetition of Henri B's actions, including photographing scenes he photographs, highlights that through imitation "the original intent has been replaced or overwritten by the motive of mimicry. Meaning is lost and the resulting images slip anchor. ${ }^{256}$ It is this sense of slippage that I accentuate in my discussions of Calle's following projects by highlighting the contingency of Calle's autofictional documents.

Many writers discuss Calle's following projects by exploiting the rhetoric and metaphors of detection and sleuthing, emphasizing Calle's pursuit of Henri B (Robert L. Pincus, Sheena Wagstaff, Linda Weintraub, Robert Storr, Whitney Chadwick). My dissertation considers more intently the scope and significance of the (autofictional) trace, as origin effaced.

Along with Johnnie Gratton and Martha Buskirk, it is Yve-Alain Bois and Janet Hand, as well as Michael Sheringham and Shirley Jordan from French literary studies, who offer the most fertile reading of Calle's work. Johnnie Gratton and Michael Sheringham link her work to French literary projects

\footnotetext{
${ }^{55}$ Sophie Calle, Suite vénitienne, Double Game, 89.

${ }^{56}$ Emma Cocker, "Desiring to be Led Astray," Papers of Surrealism 6 (2007): 20.
} 
concerned with constraints, like those of the OULIPO [Ouvroir de littérature potentielle], a group that included French writer Georges Perec. Perec is woven into Calle's work (and my thesis) in subtle ways. Calle's most overt reference to Perec is the inclusion of Perec's novel W: Souvenir d'enfance in a photograph in Days Under the Sign of $B, C$ and $W$; more subtle references are perhaps the strength with which Calle, like Perec, makes observations and attempts to record everyday interactions which I discuss in Chapter Three and Chapter Five. Perec is not only known for his use of constraints, but also for an interest in the everyday, along with an interest in fiction, memory and autobiography, and is considered an important figure in the development of autofiction. ${ }^{57}$ According to Michael Sheringham, Perec is a figure known for his "autobiographical excavation and ludic fictionalization." 58

My interdisciplinary research proposes that autofiction, understood to be a mingling of fact (autobiography) and fiction (invention), might be a useful critical tool for thinking about the relationship between the durational event (as performance) and its documentation, particularly performance that involves what are understood to be autobiographical acts. By reiterating the impossibility of the document to reproduce the event and by drawing attention to how the autofictional document challenges notions of presence and origin, my discussion underlines the importance of undecideability in the autofictional document. As autofictional performance remains, Calle's documents enact a

\footnotetext{
${ }^{57}$ Michael Sheringham, "After Perec: Dissemination and Diversification," in Everyday Life: Theories and Practices from Surrealism to the Present (Oxford: Oxford University Press, 2006), 346.

${ }^{58}$ Ibid.
} 
more fluid understanding of the event and its documentation suggesting a more reciprocal and open relationship between performance and image. As readers and viewers of these documents, the performance event and its significance, is thus "constructed in reciprocities: in processes of exchange and difference over time. ${ }^{.59}$

\section{Chapter Outline}

Chapter One introduces Calle's and Auster's exchanges and focuses on the importance of undecideability, reiteration and difference in Calle's autofictional texts and visuals. By looking at Calle's annotations to Auster's pages in Leviathan, and at The Chromatic Diet, her enactment of Auster's project written for Maria, I engage with poststructuralism to point to the impossibility of "truth" and "origin" with respect to the events described and underline the impossibility of fully knowing what was enacted.

The second chapter looks closely at Suite vénitienne, in which Calle follows a man she does not know to Venice, along with The Detective, in which a detective notes Calle's movements for the day. In this chapter I consider the status of the photograph in these works. By underscoring the contingency of her photographs, I suggest that these photographs are neither documentary nor illustration (as argued by Martha Buskirk and Johnnie Gratton) but both and neither. By drawing on Rune Gade and Anne Jerslev's collection of essays, Performative Realism: Interdisciplinary Studies in Art and Media, I introduce the concept of performative realism to existing debates about Calle's photographs.

\footnotetext{
${ }^{59}$ Gabriella Giannachi, Nick Kaye and Michael Shanks, "Introduction," in Archeologies of Presence: Art, Performance and the Persistence of Being (London and New York: Routledge, 2012), 21.
} 
Chapter Three considers to what extent The Birthday Ceremony, The Hotel, Days Under the Sign of B, C and W, and The Address Book exploit the hermeneutics of the archive as a collection of documents and/or objects that act as a record of a past event, a person, or an experience. I suggest that these projects play with archival desire and the authority of the archive by accentuating the absences and the fictional in Calle's autofictional traces.

In Chapter Four I focus on The Striptease, a project that seemingly documents Calle's job as a striptease artist in Pigalle. I consider the relationship between autobiographical acts and female subjectivity by pointing to the fictions associated with the autobiographical female subject in representation. The repetition of codes associated with the striptease is undermined as Calle's erotic failure is turned into a crime scene.

Chapter Five returns to archives suggesting that the archive and what it holds emerge together. I situate the act and its documentation as co-dependent and propose that Gotham Handbook opens the archive to a larger social context where competing discourses and voices are heard, rather than individual and singular voices and narratives. Gotham Handbook focuses on actions and transactions as a way to produce an archive as Calle transforms the unremarkable and the ordinary into "documents of culture and history." 60

For the titles of my chapters I chose to employ the word like, for it announces both a resemblance to, yet a separation from, thereby accentuating the spaces between the individual and the subject (and event) in

\footnotetext{
${ }^{60}$ Sven Spieker, The Big Archive: Art from Bureaucracy (Cambridge, Massachusetts: The MIT Press, 2008), $x$.
} 
representation(s). Perhaps I should have used the French word "comme" which in French means both as if and like and directly references the quote from Roland Barthes at the beginning of his "autobiographical novel" which I discuss in Chapter One.

This dissertation introduces Double Game as a collection of autofictional documents: an archive. By highlighting the importance of undecideability, contradiction, fiction, and absence, I propose that Sophie Calle's work not only opens the structure and the content of the archive to play, but also foregrounds contingency, relationality, and plurality. There is always space between what (perhaps) occurred, what is said to have occurred, and what is represented. Double Game underlines the ways in which events as texts are continually retold and reinvented, and also reinforces movement between: between texts, between authors, between readers. As a collection of autofictional remains Double Game performs the autofictional subject at play in the archive. 


\section{CHAPTER ONE: LIKE A CHARACTER OUT OF A NOVEL (Annotated Pages from Leviathan, The Chromatic Diet)}

The truth? Which truth? Your truth? Their truth? The truth today at two o'clock in New York, or the truth tomorrow at five o'clock in Paris? The truth now that it's raining? What does it mean? Me, I would say things happened or didn't happen, but I would not say that's the truth. ${ }^{61}$

Life never does more than imitate the book and the book itself is only a tissue of signs, an imitation that is lost, infinitely deferred. ${ }^{62}$

Like the smaller copyright page for both Double Game and Leviathan, there is a second insert included in Double Game; it is the title page and pages sixty to sixty-seven of Auster's Leviathan. These are the pages where Auster describes Maria's/Calle's life and projects, both the ones 'borrowed' from Calle and the ones he invented for his character. These pages are particularly important since it is here that we first encounter Maria/Calle in her textual and fictional form. I propose that these first few pages set up a number of conditions for reading Double Game in its entirety.

The first section of this chapter introduces Calle and Auster's exchange through a consideration of these annotated pages where we encounter Maria/Calle. By aligning Calle's work with poststructuralism and poststructuralist understandings of repetition, I argue that these pages help accentuate autofiction's reliance on doubt. In turn, this emphasis on doubt underlines the impossibility of truth, origins, and return, as well as my insistence on reading Double Game as a book that grapples with the fraught relationship between autobiography, truth, and fiction.

\footnotetext{
${ }^{61}$ Calle, "Interview with Shelia Heti," 49.

${ }^{62}$ Roland Barthes, "The Death of the Author," in Image, Music, Text, trans. Stephen Heath, (New York: Hill and Wang, 1977), 147.
} 
The second part of my chapter looks at Calle's first project in Double Game, The Chromatic Diet (1997), in which Calle documents and describes her reenactment of Auster's project written for Maria. The Chromatic Diet underscores the space between what was enacted and what is said and/or shown to have been enacted: we can never know what "happened."

\section{Calle's Annotated Pages of Auster's Leviathan}

On the first annotated page of Auster's novel Calle has written "Hello Maria," across the page in red ink, and continues to mark up the rest of the pages. By crossing out some of Auster's words and writing in her own above, Calle changes the fictional elements back to those that are supposed to represent more accurately her own life experiences and the projects in Double Game. She also comments in the margins, making more obvious Auster's inventions: "excessive", "excessive again", "over the top", "too much imagination." For example, at the top of page sixty-four in Leviathan, we read: "The next morning (week), she caught a flight (train) from La Guardia to New Orleans (Venice), checked into a hotel, and bought herself a black (blonde) wig" (figure 4$).{ }^{63}$ Calle is referring to her project Suite vénitienne (1981) in which she meets a man at a party and decides to follow him to Venice; the blonde wig is her disguise.

\footnotetext{
${ }^{63}$ Calle, Annotated Page 64 from Paul Auster's Leviathan, reprinted in Double Game, unpaginated.
} 
on a trip to New.Orleans with his girlfriend. Maria would go there as well, she decided, and follow him around with her camera for the entire length of his visit. She had absolutely no interest in him, and the last thing she was looking for was an amorous adventure. Her intention was to keep herself hidden, to resist all contact with him, to explore his outward behavior and make no effort to interpret what she saw. The next morning, she caught a flight from LaGuardial to New Orfeans) checked into a hotel, and bought herself a black jig. For three days she made inquiries at dozens of hotels, trying to track down the man's whereabouts. She discovered him at last, and for the rest of the week she walked behind him like a shadow, taking hundreds of photographs, documenting every place he went to. She kept a written diary as well, and when the time came for him to go back to New Yorks, she returned on an earlier flighte- in order to be waiting at the pirport for a last sequence of pictures as he stepped off the plănề It was a complex and disturbing experience for her, and it left her feeling that she had abandoned her life for a kind of nothingness, as though she had been taking pictures of things that weren't there. The camera was no longer an instrument that recorded presences, it was a way of making the world disappear, a technique for encountering the invisible. Desperate to undo the process she had set in motion, Maria launched into a new project just days after returning to New York, Walking through frimes Squand with her camera one afternoon, she got into a conversation with the doorman of a toptess go-go ban. The weather was warm, and Maria was dressed in shorts and a T-shirt, an unusually skimpy outfit for her. But she had gone out that day in order to be noticed. She wanted to affirm the reality of her body, to make heads turn, to prove to herself that she still existed in the

plattermpeyes of others. Maria was well put together, with long legs and attractive breasts, and the whistles and lewd remarks she received that day helped to revive her spirits. The doorman told her that she was a pretty girl, just as pretty as the girls inside, and as their conversation continued, she suddenly found herself being offered a job. One of the dancers had called in sick, he said, and if she wanted to fill in for her, he'd introduce her to the boss and see if something couldn't be worked out. Scarcely pausing to think about it, Maria accepted. That was how her next work came fea fe into being, a piece that eventually came to be known as The Naked tady) Maria asked a friend to come alonglthat night and take pictures of her as she performed - not to show anyone, but for herself, in order to satisfy her own curiosity about what she looked like. She was consciously turning herself into an object, a nameless figure of desire, and it was crucial to her that she th understand precisely what that object was. She only did it that once, working in twenty-minute shifts from eight o'clock in the evening until two in the morning, but she didn't hold back, and the whole time she was on stage, perched behind the bar with colored strobe lights bouncing off her bare skin, she danced her heart out. Dressed in a rhinestone $G$-string and a pair of two-inch heels, she shook her body toloud reek and roll and watched the men stare at her. She wiggled her ass at them, she ran her tongue over her lips, she winked seductively as they slipped her dollar the bills and urged her on. As with everything else she tried, Maria top was good at it. Once she got herself going, there was hardly any stopping her.

As far as I know, she went too far only once. That was in the spring of 1976 , 1 and the-ultimate -ffeets-of her-misealeulation proved to be catastrophic. At least two lives were lost, and even though it toek years for that to happen, the connection between the past-and the-present-is-ineseapable. Maria-was the-link between-Sachs and Lillian-Stern, and if not for-Maria's habit-of between-Sachs and Lillian-Stern, and if not for Maria's habit-of never-would have entered the picture. After Maria turned up at Sachs's a partment in 1979, a meeting between Sachs and Lillian Stern became possible. It took several more unlikely twists before that pessibility was realized, but each of them can be traced directly back to Maria. Long before any of us knew her, she went out one morning to buy film for her camera, saw a little black address book lying on the ground, and picked it up. That was the event that started the whole miserable story. Maria-opened the

65

Figure 4. Calle, with the participation of Paul Auster, annotated pages 64 and 65 from Paul Auster's Leviathan, reprinted in Double Game, unpaginated.

In these annotated pages where Calle has highlighted (and corrected)

the moments where the text refers to her life experiences, we think we

understand immediately the overlap between Auster's fiction and Calle's life.

The experiences of Calle are played out, and over, the experiences of Maria, which are already a repetition of Calle's autofictional projects. We might associate these markings with editing and revising by making notes on a text to help the writer enhance their writing and by making the details fit her life experiences. On the one hand, Calle appears to be reclaiming the 
"autobiographical truth," untangling her life events from the fictionalized ones by remarking and reclaiming her own experiences and reasserting her authorship. However, rather than reading Calle's markings as an attempt to reclaim the author, the origin, the truth, etc., I propose that Calle's writing over the text has more to do with the impossibility of origins and return, through her play with repetition and difference

In his influential essay, "The Death of the Author," Roland Barthes disrupts the (pre)conceived relationship between the author/text/reader and proposes the "death of the author," connecting this authorial disappearance to a loss of origin: "As soon as a fact is narrated... the voice loses its origin, the author enters into his own death, writing begins." ${ }^{64}$ For Barthes, "writing is the destruction of every voice, of every point of origin. Writing is that neutral, composite, oblique space where our subject slips away, the negative where all identity is lost, starting with the very identity of the body writing." ${ }^{\text {"65 }}$ Barthes contends that it is language that speaks, not the author.

Christine Macel in her catalogue essay for Calle's retrospective at the Centre Pompidou (2007) proposes that Sophie Calle refuses "sacrificial temptation," that is, the death of the author. ${ }^{66}$ In fact, Macel works hard to convince us that Calle "proclaims loud and clear, that it is her, the authornarrator-character Sophie Calle, who is involved, and this, in Philippe Lejeune's view, means that the genre is autobiographical. ${ }^{67}$ Conversely, I propose that

\footnotetext{
${ }^{64}$ Barthes, "The Death of the Author," 142.

$65 \mathrm{Ibid}$.

${ }^{66}$ Macel, "The Author Issue in the Work of Sophie Calle. Unfinished," 17.

${ }^{67}$ Ibid., 21.
} 
Calle's work can be read against Macel's positioning and actually engages poststructuralism in a way that understands the precarious relationship between autobiographical acts, fiction, and representation—one in which an overtly fragmentary, fictional, and slippery subject evolves.

This slipperiness of the relationship between the authorial and the autobiographical subject is acknowledged by Roland Barthes in his "autobiographical" work Roland Barthes by Roland Barthes (1975). Throughout his book, Barthes uses "I", "R.B.", and "He" interchangeably and at the very beginning of his book acknowledges that the writer of the autobiography does not merge with the autobiographical subject. Barthes' book begins with these words: "Tout ceci doit être considéré comme dit par un personnage de roman [It must all be considered as if spoken by a character in a novel]" (figure 5). ${ }^{68}$

${ }^{68}$ Barthes, Roland Barthes by Roland Barthes, unpaginated. 


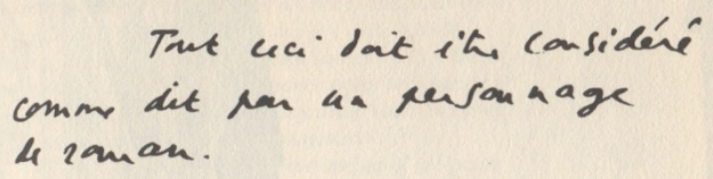

It must all be considered as if spoken by a character in a novel.

Figure 5. Roland Barthes, Roland Barthes by Roland Barthes, trans. Richard French (New York: Hill and Wang, 1977), unpaginated.

The slipperiness of Calle as author and as subject of her autofictional enunciations is acknowledged by Yve-Alain Bois who remarks: "To become a paper tiger, the character of a novel or of an 'autobiography' (to ensure that these two things amount to the same), that is what Calle has been working at, by proxy, for many years." ${ }^{69}$ Later in his text, Barthes writes, “... today the

\footnotetext{
${ }^{69}$ The "paper tiger" refers to both a book by Olivier Rolin, as well as a catch phrase used by
} Maoist activists during the Vietnam War to designate American imperialism. Yve-Alain Bois, 
subject apprehends himself elsewhere, and "subjectivity" can return at another place in the spiral: deconstructed, taken apart, shifted without anchorage: why should I not speak of 'myself' since this 'my' is no longer the 'self'?"70 This deconstruction of the subject, in which the subject is continually displaced, is important to both autofiction and to Calle's Double Game. ${ }^{71}$

The cover of Double Game already acknowledges and announces this slippage. The cover, which depicts Calle in bed with a dead, stuffed cat around her neck is re-enacting one of Maria's projects, authored by Auster, Days Under the Sign of $B, C$ and $W$, in which a letter of the alphabet dictates the activities of each day: "To be like Maria, I spent the day of Tuesday, March 10, 1998, under the sign of B by taking on the appearance of a Big-Time Blonde Bimbo. (For the model of this photograph, see Paris Match of November 2, 1989, and the portrait of BB, who in recent years has taken her preference for the cause of animals over that of humans to the point of caricature.)" ${ }^{n 2}$ The photograph on the cover of Double Game, is a slightly different version of the photograph that is included in Days Under the Sign of B, $C$, and $W$ in which we see Calle in bed again, the cat no longer on her shoulders but on the bed with an assortment of other stuffed animals: owls, a fox, a bull's head, a deer, a squirrel, etc. (figure 6). Under the photo is written: "B for Beauty and the Bestiary, for Bat, Bantam, Boar, Bull, for Bug, Badger, Bray, Bellow, Bleat, Bark, for Beastly Birdbrain, for

\footnotetext{
"Paper Tigress," October 116 (Spring 2006): 40.

${ }_{71}^{70}$ Barthes, Roland Barthes by Roland Barthes, 168.

${ }^{71}$ The use of only the initials as referent is adapted by Calle in many of her projects: BB (Days Under the Sign of B, C and W); Henri B, Dr. Z (Suite vénitienne); Count and Countess $M$ and Ambassador O (The Hotel); Jacques D (The Address Book). Serge Doubrovsky in his second book, Un amour de soi, also uses his initials, as does Roland Barthes Roland Bathes by Roland Barthes.

${ }^{72}$ Sophie Calle, Days Under the Sign if B, C and W, Double Game, 24-25.
} 
BB. ${ }^{73}$ The photograph is an obvious parody of French actress Brigitte Bardot, once the ultimate sex symbol, now known more for her love and protection of animals to "the point of caricature." Both photos makes obvious the mobility of the subject as we see the layering of Bardot on top of Calle on top of Maria on top of Calle-already deferred and displaced through textual representation.

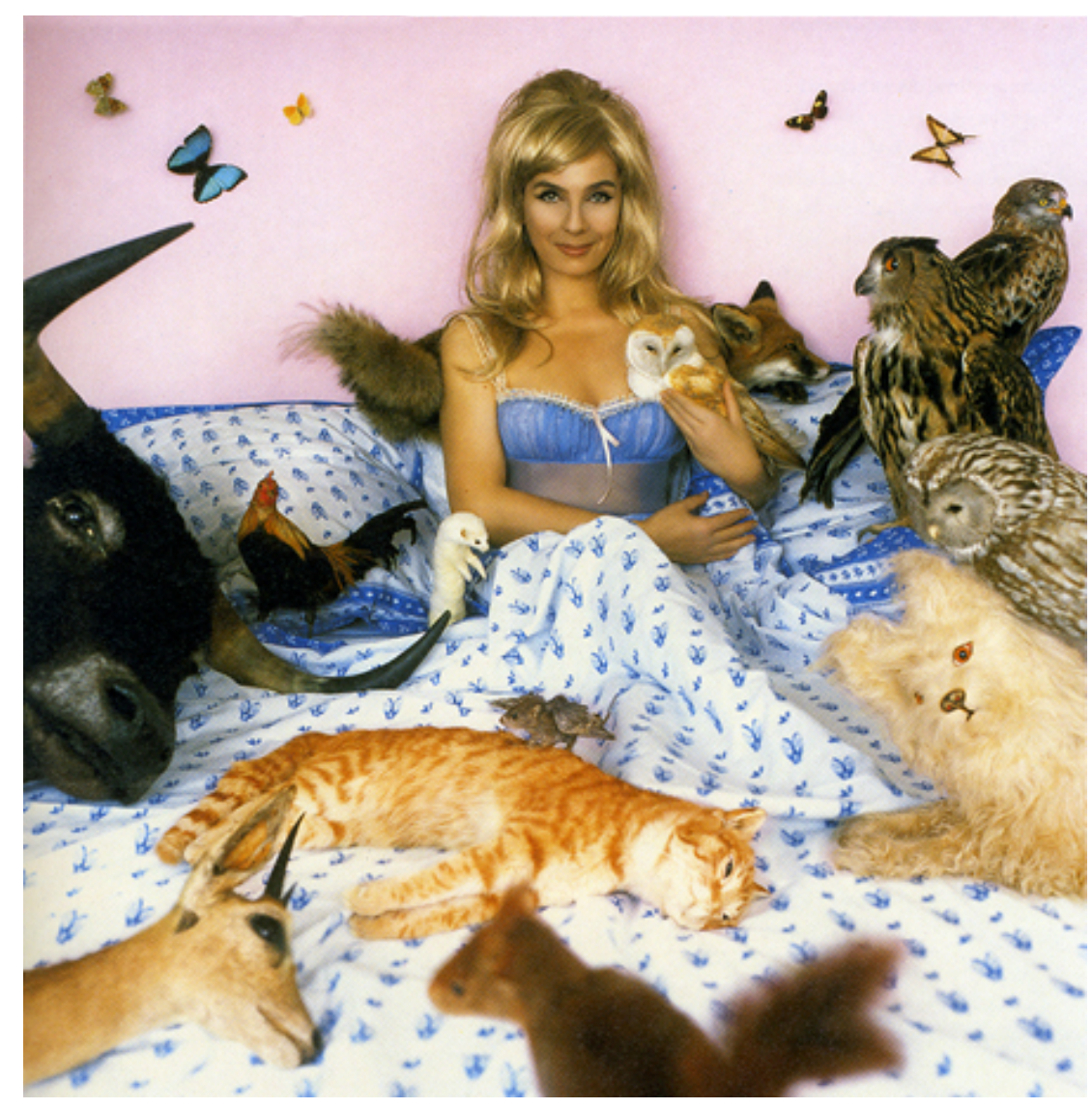

Figure 6. Sophie Calle, "B for Big-Time Blonde Bimbo," Days Under the Sign of $B, C$ and W, Double Game, 25.

Calle's markings over Auster's text similarly make literal this act of displacement, as well as Barthes' understanding of a text as "a multi-

${ }^{73}$ Calle, Days Under the Sign of B, C and W, 24-25. 
dimensional space in which a variety of writings, none of them original, blend and clash. The text is a tissue of quotations." ${ }^{\prime 74}$ Barthes continues, "His [the writer's] only power is to mix writings, to counter ones with the others, in such a way as never to rest on any one of them." ${ }^{75}$ The rewriting of the events over and above Auster's fiction suggests instead another kind of referentiality, one that points not to the truth of narrated events, but rather to how narrated events, as text, are always made up of other texts and open to endless revisions and reiterations. Repetition here can be seen as a reframing, a reframing in which the repetition accentuates play and difference, between the authors, as well as between the events and their representation. Barthes writes, "life never does more than imitate the book and the book itself is only a tissue of signs, an imitation that is lost, infinitely deferred." ${ }^{76}$

This perpetual reframing suggests more alliances with poststructuralism, both with Derrida's concept of sous rature (under erasure) and différance. By placing a word or a concept under erasure, visually putting a line through it-a visual deconstruction-Derrida seeks to identify sites within texts where key terms and concepts may be paradoxical or self-undermining, rendering their meaning undecidable - it is this and not this—both and neither. While Derrida uses this for key concepts, I argue that these annotations to Auster's words might be read in this way, which, rather than placing Calle's life experiences in tension with the fictional experiences of Maria, engage the Derridean sous rature, to again stress that there is no original moment, or meaning, but only a

\footnotetext{
${ }^{74}$ Barthes, "The Death of the Author," 146.

${ }^{75}$ Ibid.

${ }^{76}$ Ibid. 147.
} 
series of reiterations. Calle thus places Auster's words sous rature to highlight the fact that it is this and not this. Throughout Double Game, Sophie Calle is always displaced and deferred. The red ribbon around the cover, cutting through the image of Calle as Maria as Bardot, might also be read as the visual and photographic equivalent to her striking through of Auster's words. It is difference that is important here, not only between Auster's and Calle's accounts, but also between Calle's written words here on these pages and her accounts on the other pages of Double Game, reiterations, as Derrida would argue, that are the same, but never identical. ${ }^{77}$

Derrida's différance is "literally neither a word or a concept." ${ }^{\text {"78 }}$ It is connected to his critique of logocentrism where speech (as presence and authority) is privileged over writing. It is "purely graphic: it is read, or it is written, but it cannot be heard." ${ }^{79}$ Différance is also connected to deferral, itself a play between absence and presence, where meaning is never fully present, but relational in an endless process of referral to other, absent signifiers. There is only difference, difference as play. Both sous rature and différance lead us to the potential impossibility of a univocity of meaning ever having been attached to the word, term, or sign in the first place.

In Calle's work there is continual play with the concepts of origin and truth. By providing verifiable details, such as dates, people, places, etc., Calle seemingly authenticates the event, only to put into doubt the events narrated as

\footnotetext{
${ }^{77}$ Jacques Derrida "Implications: Interview with Henri Ronse," in Positions, trans. Alan Bass (Chicago, London: University of Chicago Press, 1972), 9.

${ }_{8}$ Jacques Derrida, "Différance," in Margins of Philosophy, trans. Alan Bass (Chicago:

University of Chicago Press, 1982), 3.

${ }^{79}$ Ibid., 4.
} 
textual and visual descriptions do not always correspond with each other, and/or because fictions are exposed. The reader/viewer is implicated in Calle's game from the beginning and we read Double Game looking for moments in which we can actually separate fact from fiction.

According to Carolyn Steedman, "Derrida has long seen in Freudian psycho-analysis a desire to recover moments of inception, beginnings and origins which—in a deluded way-we think might be connected to some kind of truth, and in Archive Fever, desire for the archive is presented as part of the desire to find or locate, or possess that moment of origin, as the beginning of things." 80 Calle's work thus plays with our own desire for "inception, beginnings and origins." And this is where I think Calle's playful constructions are particularly poignant as they disavow any notion that the actuality of the event has more value, or truth, than the mediation of the event. ${ }^{81}$ Like the detective, we believe the evidential traces presented to us in both her texts and photographs will lead us back to some original moment, the scene of the crime-before the death of the author.

\section{The Desire for Origin}

Literary critic Peter Brooks' reading of Sigmund Freud's "From the History of an Infantile Neurosis [The 'Wolfman']' is useful in thinking about origins, desire, narration and fiction. Brooks argues that Freud's case history of the Wolf Man

\footnotetext{
${ }^{80}$ Carolyn Steedman, Dust: The Archive and Cultural History (New Jersey: Rutgers University Press, 2002), 3.

${ }^{81}$ This is in line with Amelia Jones' positioning of performance documentation: "while the experience of viewing a photograph and reading a text is clearly different from that of sitting in a small room watching an artist perform, neither has a privileged relationship to the historical "truth" of the performance." Amelia Jones, "Presence' in Absentia: Experiencing Performance as Documentation," Art Journal 56, no. 4 (Winter 1997): 11.
} 
asks questions about how we narrate the events in our own life, and about how meaning is established. ${ }^{82}$ As Brooks points out, the analogies between psychoanalytic investigation and detective work and, as I argue, archival work, all (re)turn to the idea of reconstruction—primarily based on narrative explanation (as evidence) ${ }^{83}$

Freud's narrative is a detective story, a case history, a biography, a story of origins, as well as a self-conscious interrogation into the ways we construct identity through the stories that we tell about ourselves. Brooks argues that Freud must structure the Wolf Man's narrative based on fragmentary accounts and clues in such a way that it leads us back to the primal scene-the scene of origin—taking into account overlapping structures ${ }^{84}$ However, after finishing his initial narrative and reconstructing the "crime scene," Freud questions this reality and offers another version, a less convincing story of origin. The final account, like these annotated pages, contains both narratives as "a kind of palimpsest, a layered text that offers differing versions of the same story." ${ }^{85}$

For Brooks, the repetitive nature of this return, this doubling back to the primal scene, displaces questions of origins by suggesting multiple versions, in which the narrated primal scene may be fictional. Brooks writes "[A]ll tales may lead back not so much to events as to other tales, to [wo]man as a structure of

\footnotetext{
${ }^{82}$ Peter Brooks, "Fictions of the Wolf Man," in Reading for the Plot: Design and Intention in Narrative (New York: Vintage Press, 1984), 268.

${ }^{83}$ Brooks, "Fictions of the Wolf Man," 270.

${ }^{84}$ This parallels Derrida's understanding of archival desire: "It is to burn with a passion. [...] It is to have a compulsive, repetitive, and nostalgic desire for the archive, an irrepressible desire to return to the origin, a homesickness, a nostalgia for the return of the most archaic place of absolute commencement." Jacques Derrida, Archive Fever: A Freudian Impression, trans. Erik Prenowitz (Chicago: University of Chicago Press, 1995), 91.

${ }^{85}$ Brooks, "Fictions of the Wolf Man," 277.
} 
fiction [s] he tells about him[her]self." ${ }^{86}$ I propose that Calle's writing over Auster's text, rather than offering a return to the scene of origin, offers instead another version of the events to help draw attention to the ways in which we continually (re)construct and (re)produce ourselves and our lives through narrative.

Brooks even suggests that "the 'true' narrative lies in between, in the process of exchange; or is the product of two discourses playing against one another, often warring with one another...." ${ }^{87}$ In the case of the Wolf Man, the patient comes to the analysand with a "story to tell, a story that is not so much false-since it does in some manner signify the truth—as it is incomplete and untherapeutic." 88

For Brooks, Freud's case history of the Wolf Man grapples with issues of fictionality, "since its causes and connections depend on probabilistic constructions rather than authoritative fact...." ${ }^{89}$ Thus autobiographical narration, understood as "probabilistic constructions," opens up narrative and life-writing in such a way that the events recounted and their reworking is far more fluid and open. This, as Brooks points out, all return us to the "acute issue" of undecideability as it relates to origins. ${ }^{90}$ In Brooks' terms then, Calle's projects contained within Double Game and her specific annotations of these pages, like Freud's narrative(s), offer potential "postures and possibly reversible

\footnotetext{
${ }^{86} \mathrm{Ibid}$.

${ }^{87}$ Ibid., 283.

${ }^{88} \mathrm{lbid}$.

89 Ibid., 284.

${ }^{90}$ Ibid., 275-276.
} 
chains of association." ${ }^{91}$ The relationship between the "event and its significant reworking, is one of suspicion and conjecture, a structure of indeterminacy which can offer a framework of narrative possibilities rather than a clearly specifiable plot." 92

Calle's first project in Double Game, The Chromatic Diet, plays with the limits of the representation of autobiographical acts. Through processes of narration and documentation, the event is shown to be one of "suspicion and conjecture." By drawing attention to the impossibility of fully knowing the events described, The Chromatic Diet explores the space between the event, and its "significant reworking."

\section{The Chromatic Diet}

Like all of Calle's projects, The Chromatic Diet begins with les règles de jeu: "To be like Maria, during the week of December 8-14, 1997, I ate Orange on Monday, Red on Tuesday, White on Wednesday and Green on Thursday. Since Paul Auster had given his character the other days off, I made Friday Yellow and Saturday Pink. As for Sunday, I decided to devote it to the full spectrum of colours, setting out for six guests the six menus tested over the week. ${ }^{93}$ Here Calle explicitly highlights her attempt to "be like Maria," as well as the duration of the daily ritual. Like many of her projects, these temporal details of its enactment, dates, duration, etc., help ground her accounts of the project in the believable-as a fastidious report of her activities.

The pages from Auster's book that describe Maria's version of each

\footnotetext{
${ }^{91}$ Ibid., 272.

92 Ibid.

${ }^{93}$ Sophie Calle, The Chromatic Diet, Double Game, 12-13.
} 
project are also printed, as photographs, at the beginning of each of Calle's projects, directly underneath "les règles de jeu." Auster describes Maria's Chromatic Diet:

Some weeks, she would indulge in what she called 'the chromatic diet,' restricting herself to foods of a single color on any given day. Monday orange: carrots, cantaloupe, boiled shrimp. Tuesday red: tomatoes, persimmons and steak tartare. Wednesday white: flounder, potatoes, cottage cheese. Thursday green: cucumbers, broccoli, spinach and so on, all the way through the last meal on Sunday. ${ }^{94}$

The inclusion of a photograph of the relevant pages from Leviathan at the beginning of this project reinforces the overlap between Calle's account of the events, already a reiteration of Maria's project, and Auster's fiction, already a reiteration of Calle's life.

The following six pages are arranged identically. A square photo shows an aerial shot of a place setting. In each photograph we see a large plate, a small plate, utensils, napkin and a drink; everything is the colour of the day, including the plastic knives and forks, the plastic plate, the food, the drink, and the background against which they are photographed (figure 7, figure 8 , figure 9 , figure 10 , figure 11 , figure 12 ).

${ }^{94}$ Auster, Leviathan, 60, reprinted in Double Game, 12 -13. 


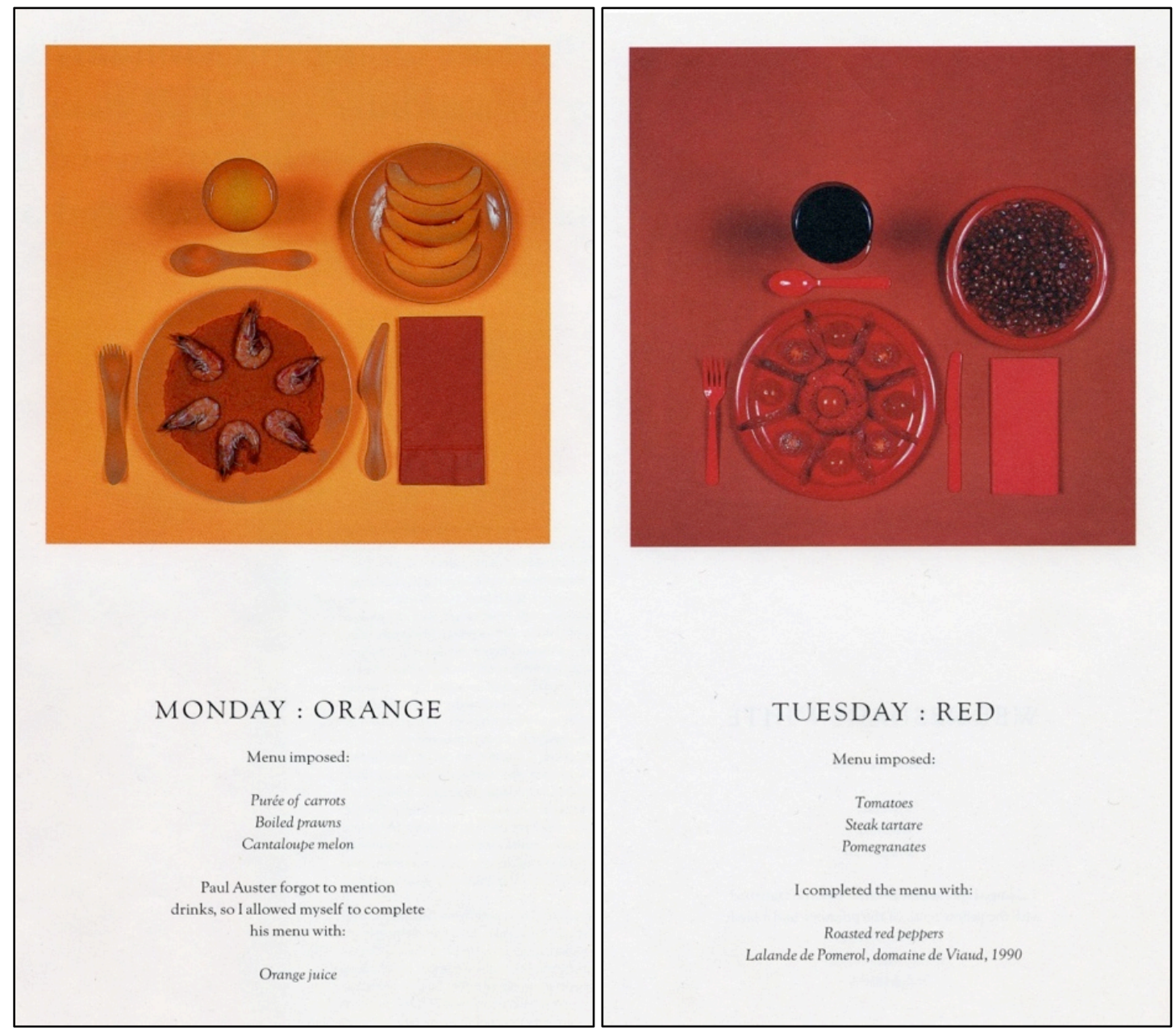

Figure 7. Calle, "MONDAY: ORANGE," The Chromatic Diet, Double Game, 14. Figure 8. Calle, "TUESDAY: RED," The Chromatic Diet, Double Game, 15. 


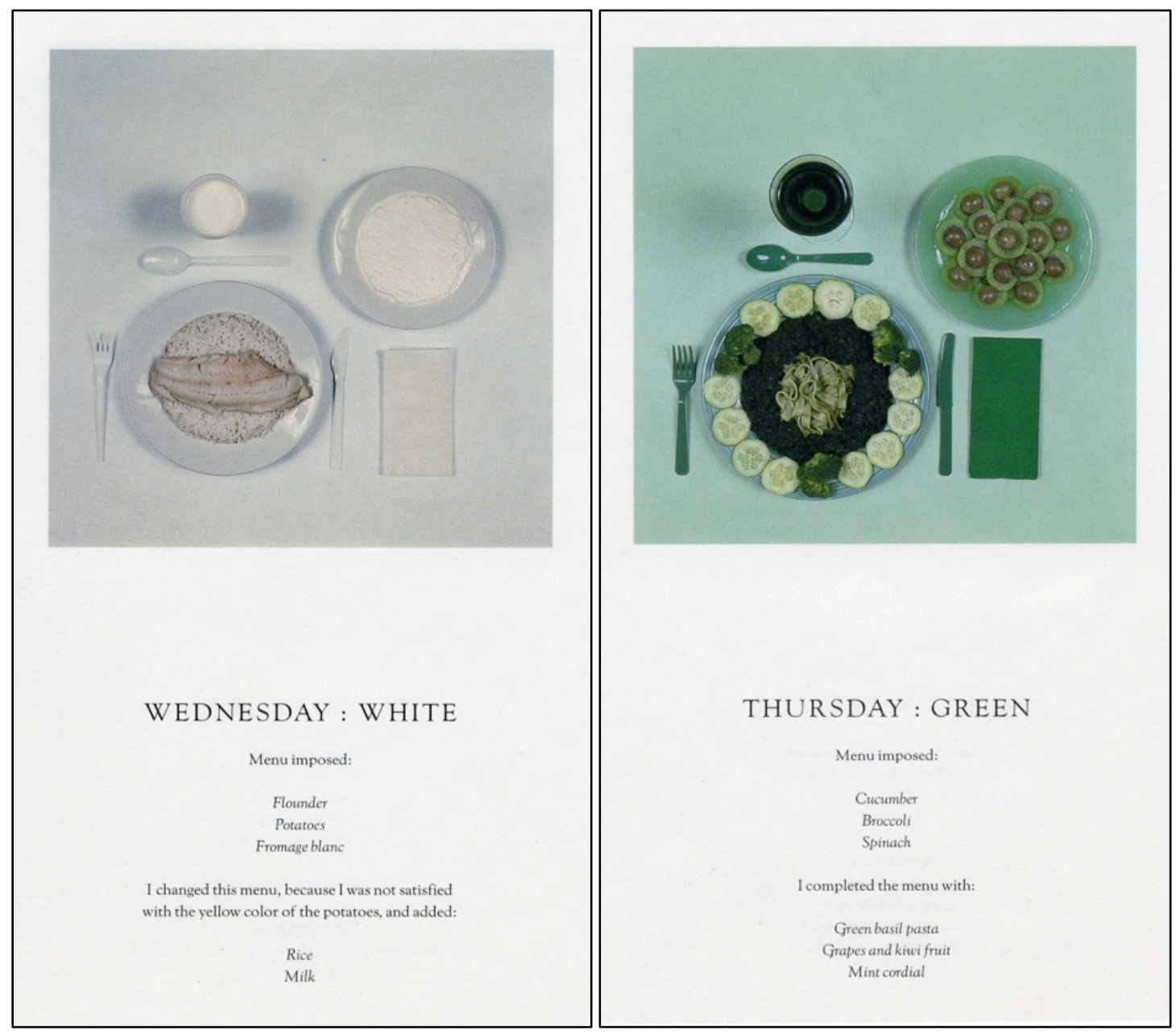

Figure 9. Calle, "WEDNESDAY: WHITE," The Chromatic Diet, Double Game, 16.

Figure 10. Calle, "THURSDAY: GREEN," The Chromatic Diet, Double Game, 17. 


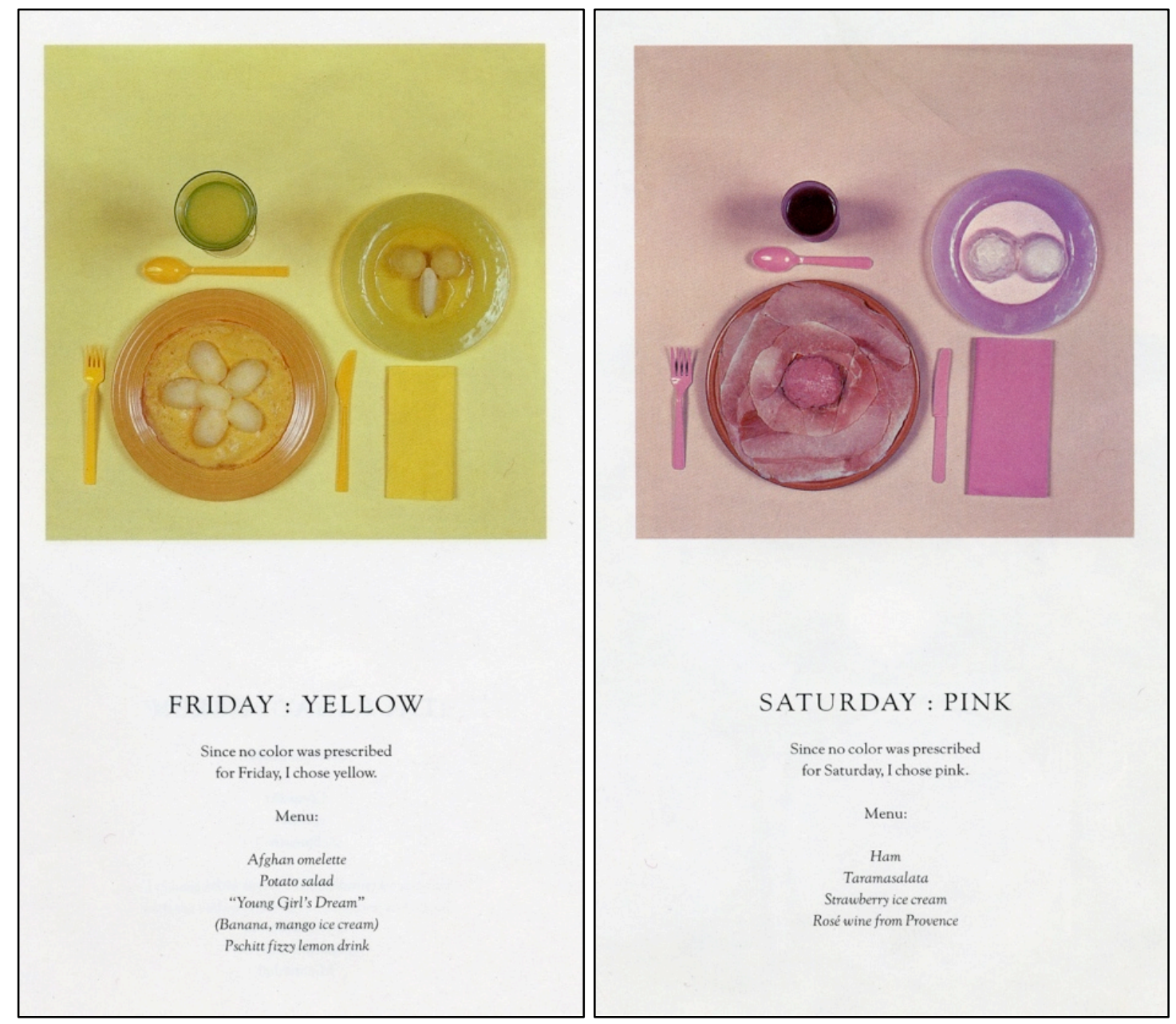

Figure 11. Calle, "FRIDAY: YELLOW," The Chromatic Diet, Double Game, 18. Figure 12. Calle, "SATURDAY: PINK," The Chromatic Diet, Double Game, 19.

Under each image, in a larger font and in capital letters are written the days of the week and the colour associated with that particular day. The textual arrangement conjures up both a menu and a report and the photographs 
appear to offer domestic, and rather controlled, versions of abstract expressionist monochrome paintings. The text identifies what Calle decided to prepare according to Auster's text, as well as her own additions and deviations, often noting Auster's omissions. Like the annotated pages at the beginning of Double Game, The Chromatic Diet not only reiterates Auster's text, through sameness, but also highlights the gaps and differences:

MONDAY: ORANGE.

Menu Imposed: Puree of carrots, Boiled prawns, and Cantaloupe melon.

Paul Auster forgot to mention drinks, so I allowed myself to complete his menu with: Orange Juice.

TUESDAY: RED.

Menu Imposed: Tomatoes, Steak tartare, Pomegranates [instead of persimmons].

I completed the menu with Roasted red peppers, Lalande de

Pomerol, Domaine de Viaud 1990.

WEDNESDAY WHITE.

Menu Imposed: Flounder, Potatoes, Fromage blanc.

I changed this menu, because I was not satisfied with the

yellow colour of the potatoes, and added: Rice, Milk.

THURSDAY: GREEN.

Menu Imposed: Cucumbers, Broccoli, Spinach.

I completed the menu with: Green basil pasta, Grapes and

kiwi fruit, Mint cordial.

FRIDAY: YELLOW.

Since no colour was prescribed for Friday. I chose yellow.

Menu: Afghan omelet, Potato salad, "Young Girl's Dream"

(Banana, mango ice cream), PSchitt fizzy lemon drink.

SATURDAY: PINK.

Since no colour was prescribed for Saturday; I chose Pink.

Menu: Ham, Taramasalata, Strawberry ice cream, Rosé wine from Provence. ${ }^{95}$

In the same way that Calle writes across Auster's pages at the beginning of

Double Game, here she inserts her own directives, seemingly reclaiming her

\footnotetext{
${ }^{95}$ Calle, The Chromatic Diet, 14-19. "Young Girl's Dream" is a reference to an episode in Calle's Des histoires vraies, in which, as a young girl, she is served a banana with two scoops of ice cream that are arranged to resemble male genitalia.
} 
authorial and artistic role as she deviates from Auster's written (and "imposed") text. Not only has she added Friday (yellow) and Saturday (pink), but also the last page reveals another addition to Auster's instructions:

\author{
SUNDAY: ORANGE, RED, WHITE, GREEN, YELLOW, AND \\ PINK. \\ Lots were drawn for the menus and everybody acquitted \\ themselves conscientiously, if without enthusiasm at their tasks. \\ Personally, I preferred not to eat; novels are all very well but not \\ so delectable if you live them to the letter. ${ }^{96}$
}

Along with the narration of the events of Sunday, there is a photograph that spans both pages of the book. The photograph shows each of the previous daily chromatic menus (plates of food, a drink, along with corresponding utensils and napkin), now around a table with a black cloth and a floral centerpiece of roses and carnations (figure 13).

${ }^{96}$ Calle, The Chromatic Diet, 21. 


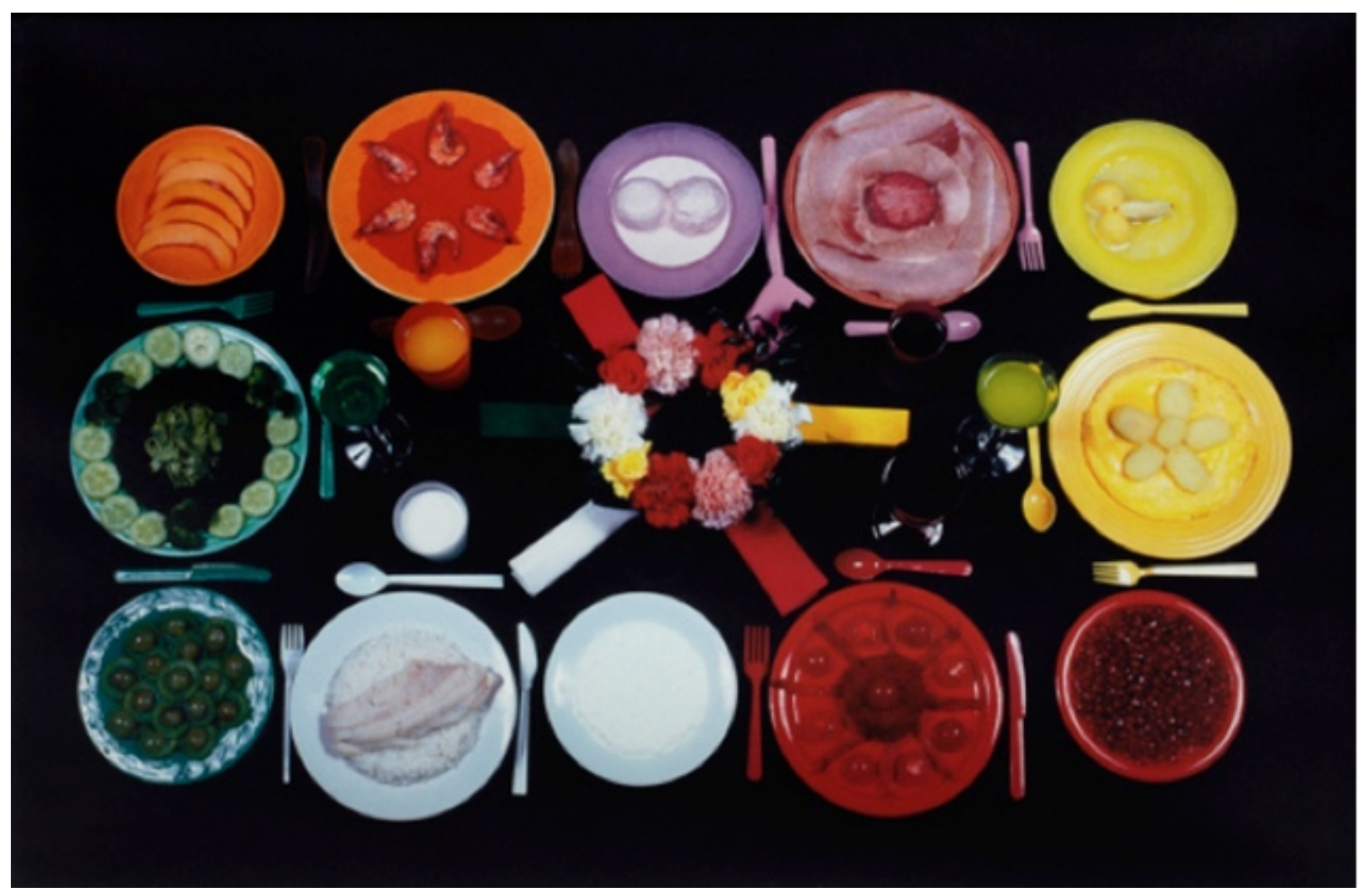

Figure 13. "SUNDAY: ORANGE, RED, WHITE, GREEN, YELLOW, \& PINK," The Chromatic Diet, Double Game, 20-21.

On the one hand, Calle's photographs provide evidence of Calle's commitment to Maria's daily ritual, as described by Auster in his novel by exploiting photography's historical function as "official truth" and "verification of an original event." ${ }^{\prime 97}$ On the other hand, however, the photographs serve to highlight that Calle's daily ritual may be fictive, as gaps and contradictions emerge between what is written, what is seen, and what is enacted. When is saying or showing the same as doing?

\footnotetext{
${ }^{97}$ Allan Sekula quoted in Charles Mereworth, "A Language to Come: Japanese Photography. After the Event," in The Archive, ed. Charles Mereworth (London, England; Cambridge, Massachusetts: Whitechapel and MIT Press, 2006), 122. Alan Sekula's "The Body and the Archive," is also important here because it stresses not only the importance of photography to the archive and the archive to photography, but also its conflicted relationship to questions of identity. See Allan Sekula, "The Body and the Archive," October 39 (1986): 3-64.
} 
Calle introduces this project by writing: "I ate Orange on Monday, Red on Tuesday, etc." However, the last photograph, when all the monochromatic meals are brought together (as yet another form of repetition), the plates of food are exact replicas of the plates seen earlier, both physically in the pages of the book, or earlier in the week in the temporal unfolding of the narration of the events of the project. If Calle was "obedient" to the text, following Auster's constraints, she would have eaten each of these plates of food on the appropriate day, making more (and perhaps slightly different ones for Sunday) when she sets out for her "six guests the six menus tested over the week." 98 Yet, these plates appear to be exactly the same plates seen earlier-so perhaps she did not eat the correct plate on the correct day, or perhaps Calle only created these plates to be photographed. As the text tells us: "Personally, I preferred not to eat; novels are all very well but not so delectable if you live them to the letter." ${ }^{\prime 99}$ While we assume that she is talking about the meal on Sunday, when she invited six guests to consume the six meals, and since the text accompanies this photograph, perhaps she is referring to all of the meals not consumed during the week. Where does the truth lie?

On the one hand we cannot help but read these photographs as a Barthesian "certificate of presence," the thing "that-has-been," describing and attesting to the monochromatic food arranged on a plate. ${ }^{100}$ Yet on the other hand, the photographs work against the text(s), for the repetition of the plates in

\footnotetext{
${ }^{98}$ Calle, The Chromatic Diet, 14.

${ }^{99}$ Calle, The Chromatic Diet, 21.

${ }^{100}$ Roland Barthes, Camera Lucida: Reflections on Photography, trans. Richard Howard (New York: Hill and Wang, The Noonday Press, 1981), 87, 77.
} 
the photograph on Sunday draws attention to the possible impossibility of the daily ritual: monochromatic food, made and consumed daily. Paradoxically, the last photograph dislodges the earlier photographs from their perceived status as that-which-has-been, failing to secure the event in both the past and in the present, as a record of the unfolding of the events during the week. The photograph is no longer an indicator of what-has-been, but rather perhapswhat-has-been.

The photographs fail to authenticate Calle's actions as described in her text ("I ate Orange on Monday...") and fail to serve as proof of her dedication to Auster's instructions. The last photograph works to unravel the way in which we read the previous photographs; we can no longer read the photographs as proof of Calle's/Maria's daily ritual. The lack of "evidence" of the daily consumption of the food also prompts us to question the limits of Calle's enactment of her text.

I suggest that it is not "truth" that is at stake here, as this project emphasizes doubt about the actuality of the events described as a way to move away from the photograph's embedded relationship with objectivity and referentiality. The Chromatic Diet highlights instead, alternative strategies for meaning making such as the relational play between Auster's novel, Calle's rules, the photographs, and the text. Calle's photographs, working with and against Auster's text, as well as her own textual description of the event, complicate the spaces between what "really happened", what is described, and what is reproduced. We can never know through the documents produced for 
The Chromatic Diet what came to pass, or the space and time in which it took place. All notions of the real, the prior, and the original are put in brackets, while the play between real time and space, and fictional time and space is continually folded over through Calle's interplay with Auster's text. ${ }^{101}$ The Chromatic Diet aligns itself with Auster's novel by reproducing an (auto)fictive space in which the performative act and its record collapse together. Does it matter if Calle actually ate "Red on Tuesday"?

\section{As Artifice}

The photographs in The Chromatic Diet highlight the visual arrangement of the food. ${ }^{102}$ The importance of the aesthetic quality of the food is made most obvious on WEDNESDAY when Calle admits that she "changed the menu, because I was not satisfied with the yellow colour of the potatoes, and added: Rice, Milk." Calle's photographs, in which she uses the high-angle shot, conform to the photographs described by Roland Barthes in his essay, "Ornamental Cookery": "both near, yet inaccessible, whose consumption can perfectly well be accomplished simply by looking." ${ }^{\text {103 }}$ Barthes argues that these photographs of food, included in women's magazine such as Elle, prize the ornamental, featuring the coatings, the glazes, etc., belonging to the "visual category, meant for the eye alone...."104 Ornamentation, according to Barthes works in two, contradictory ways: as a way of "fleeing from nature, a kind of

\footnotetext{
${ }^{101}$ Rosalind Krauss has identified this tendency of "invagination," a Derridean term meaning the folding of one story within another, in other work by Calle. Rosalind Krauss, "Two Moments from the Post Medium Condition," October 116 (Spring 2006), 59.

102 This might also be read as a subtle play on French artist Daniel Spoerri's tableaux pièges [trap pictures], such as Kichka's Breakfast (1960) where Spoerri nails the remnants of Kichka's breakfast to a table and displays them on a wall as a sculptural installation.

${ }^{103}$ Roland Barthes, "Ornamental Cookery," in Mythologies (London: Paladin, 1973), 79.

104 Ibid., 78.
} 
frenzied Baroque... while also trying to reconstitute it through an incongruous artifice." ${ }^{105}$ According to Barthes, cookery in Elle is an "idea-cookery." ${ }^{106}$ Therefore, he concludes, the photographs in Elle offer up a "fiction", a fiction that Calle highlights and refuses to consume. ${ }^{107}$ As Calle writes, "novels are all very well but not so delectable if you live them to the letter."

\section{Conclusion}

In emphasizing how Calle's annotations to Auster's novel rely on undecideability, and by underscoring the importance of repetition and difference (as the same but never identical), I have attempted to articulate the importance of poststructuralism for positioning Calle's autofictional work. Calle's annotated pages speak to the impossibility of truth, origin, and return. The Chromatic Diet explores the porosity between acts and their representation, by dissolving the boundaries between event and its documentation, between fiction and truth. By highlighting the ornamental, the visual elements of Auster's words, Calle opens up the photograph to the viewer (as maker of meaning) in the same way that Barthes opens the text to the reader. In The Chromatic Diet, we are never sure what or what did not unfold in the space of the week as fact and fiction, text and image collide.

\footnotetext{
${ }^{105}$ Ibid., 79.

${ }^{106}$ Ibid.

107 Ibid.
} 


\section{CHAPTER TWO: LIKE IN A PHOTOGRAPH (Suite vénitienne, The Detective)}

I like to tell stories and it's what I do in my work. ${ }^{108}$

Perhaps the authenticity of the performance document resides in its relationship to its beholder rather than to an ostensibly originary event: Perhaps its authority is phenomenological rather than ontological. ${ }^{109}$

Calle's following projects, To Follow... (1979), Suite vénitienne (1981), and The Detective (1981) are the most cohesive in Double Game because of their individual engagement with similar issues of shadowing and surveillance, in which the camera constructs a visual record of the events described. Perhaps even more than Calle's other projects, these following projects play with the creation of photographic "evidence." In this chapter I look closely at the status of Calle's photographs in Suite vénitienne and The Detective (sometimes called The Shadow) and consider how these works accentuate the contingency of her documents.

The earliest project is To Follow..., which consists of photographs of Calle's journals in which she recorded following strangers on the streets of Paris, "for the pleasure of following them, not because they particularly interested me, photographed them without their knowledge, took note of their movements, then finally lost sight of them and forgot them." ${ }^{\text {110 }}$ A relatively small project, the work included in Double Game consists of six pages of photographs of Calle's notebook that contains both handwritten texts and photographs.

\footnotetext{
${ }^{108}$ Lynne Cooke, "Interview with Sophie Calle," reprinted in Sophie Calle: The Reader (London: Whitechapel Gallery, 2009), 60.

${ }_{1109}$ Philip Auslander, "The Performativity of Performance Documentation," PAJ 84 (2006): 9.

${ }^{110}$ Sophie Calle, To Follow..., Double Game, 68-69.
} 
In Suite vénitienne, Calle follows a man (Henri B $)^{111}$ in the streets of Paris and like the others that she tails in To Follow... loses sight of him. However, in the rules of the game, she writes: "That very evening, quite by chance, he was introduced to me at an opening. During the course of our conversation, he told me he was planning an imminent trip to Venice. I decided to follow him." ${ }^{112}$ The project recounts her arrival in Venice, her search for Henri $B$, and her subsequent tailing of him in the city after she finally spots him, six days later. On Monday, February 11, 1980, Calle writes: "In my suitcase: a make-up kit so I can disguise myself; a blonde bobbed wig; hats; veils; gloves; sunglasses; a Leica and a Squintar (a lens attachment equipped with a set of mirrors so I can take photos without aiming at the subject)." ${ }^{113}$ These details are interjected with more subjective comments which are written in italics: "I must not forget that I don't have any amorous feelings toward Henri B. The impatience with which I await his arrival, the fear of that encounter, these symptoms aren't really a part of me."114

Suite vénitienne is a story of anticipation, suspense, and desire. The narrative often dominates Calle's work; she was famously described by Hervé Guibert as a "faiseuse d'histoire" [a spinner of tales/stories]. ${ }^{115}$ Calle makes references to the "story" many times in Suite vénitienne: "ready to get lost in the

\footnotetext{
${ }^{111}$ In Calle's projects Henri B is not followed by a period, but others like Pierre D. are. I have kept the same punctuation in my dissertation to be consistent with Calle's works.

${ }_{112}^{11}$ Calle, Suite vénitienne, 76-77.

113 Ibid., 81.

114 Ibid., 89.

${ }^{115}$ Hervé Guibert, "Panégyrique d'une faiseuse d'histoire," in Sophie Calle: à suivre (Paris: Musée d'art moderne de la ville de Paris, 1991).
} 
city and in this story [emphasis mine]; "116 "Henri B did nothing. I discovered nothing. A banal ending to this banal story [emphasis mine]."117 I stress Calle's reference to the "story" because, in French, histoire means both story and history and I reiterate Lejeune's description of autobiography and biography, which, unlike fiction, are "referential texts: exactly like scientific or historical discourse."118 I suggest that Calle's work already acknowledges the complicated relationship between history and story by playing with both referentiality and invention. Both Suite vénitienne and The Detective tell a story based on Calle's life experiences (autobiographical acts), but a story that doesn't always replicate the events as they came to pass (autofiction).

In The Detective, Calle asks her mother to hire a detective to follow her for a day, "to report on my daily activities, and to provide photographic evidence of my existence."119 This work consists of a series of photographs, presumably taken by the detective, of Calle as she moves through Paris. The images are accompanied by the detective's report. Her own diaristic account of her day is also included and serves to bring into question the "truth" of the events described, for their accounts of the events of the day differ slightly. Most obvious is that each version offers a different ending to the day. At the end of their accounts we are also given a third report (both text and photographs) from

${ }^{116}$ Calle, Suite vénitienne, 83

117 Ibid., 106.

118 Lejeune, "The Autobiographical Pact," 22.

${ }^{119}$ Sophie Calle, The Detective, Double Game, 122-123. 
a friend (François M) whom Calle asked to "photograph anyone who seemed to be tailing her." ${ }^{120}$

Both these projects have been written about extensively (Jean Baudrillard, Robert L. Pincus, Sheena Wagstaff, Linda Weintraub, Robert Storr, Whitney Chadwick) and most of the writing examines the rhetoric and metaphors of the detective and sleuthing, following and being followed. Themes of detection and the overlap between artist, detective, reader (and psychoanalyst) occur throughout much of Calle's work in which traces, clues, and evidence are produced and often fabricated to reinforce the impossibility of "recovery" of the events described: the scene of origin/the scene of the crime.

In this chapter, I elaborate on the ways Calle's Suite vénitienne and The Detective employ the photograph by playing with its ability to "furnish evidence..121 I draw extensively on Martha Buskirk's and Johnnie Gratton's writing about the photographs in Calle's Suite vénitienne and To Follow.... Gratton is actually building on Buskirk's arguments from her book The Contingent Object of Contemporary Art (2003). Both Buskirk and Gratton explore the relationship between text and image, suggesting that Calle's photographs are better understood as "illustration" ("contrived and posed" and/or "digitally altered") rather than "documentary" ("witness to events"). ${ }^{122}$

\footnotetext{
120 lbid., 138.

121 Susan Sontag, On Photography (New York: Picador, 1973), 5.

122 Johnnie Gratton, "Illustration Revisited: Phototextual Exchange and Resistance in Sophie Calle's Suite vénitienne," in Textual and Visual Selves: Photography, Film, and Comic Art in French Autobiography, eds. Natalie Edwards, Amy L. Hubbell and Ann Miller (Lincoln and London: University of Nebraska Press, 2011), 144. Johnnie Gratton is writing in response to W.J.T. Mitchell's understanding of illustration. Gratton writes: "Mitchell basically dismisses illustration for two main reasons: not only does it bring about an undesirable "suturing" of the visual to the verbal (94), it also subordinates the visual to the verbal." Ibid., 139.
} 
I aim to build on their arguments by reading Calle's photographs as performance documentation, focusing more intently on the significance and importance of this unstable relationship of the narrated event to the photograph.

I propose that the photographs in Calle's projects are not "documentary" or "illustrative" (as Buskirk and Gratton argue), but both and neither; and as such demonstrate the force with which Calle's photographs, once again, point to the unstable (autofictional) nature of her accounts. Gratton argues that the need to distinguish between "documentary" and "illustrative" uses of photography has become increasingly associated with ethics and truth telling; thus Calle's autofictional accounts in these projects would appear to test the limits of truth telling that have come to be associated with photography. Buskirk and Gratton are both interested in the way that Calle's photographs undermine their own "documentary" status and thus turn to "illustration" as a way to account for these discrepancies. It is the failure of the photographs to authenticate the events as described in the text that prompts them to consider Calle's photographs as illustration.

Gratton highlights the discrepancy between texts and images in Calle's work due in part to the indexical status of photographs: "The reader-viewer may not finally endorse their status as complementary documents, but initial consideration of the texts as disseminators of knowledge about the project, and of the photos as indexical guarantee, and iconically rich evidence that the project took place, will always come into play." ${ }^{123}$ Gratton argues that Calle's

123 Ibid., 162. 
photographs are "completely 'plausible' as visual documentation" yet they can still be "read as an inversion of the proof they posit."124

As documents of autofictional performances, or autofictional documents of performances, Calle's photographs complicate this relationship between the event and its documentation, a relationship that is already highly animated within performance studies. We can never know what was enacted. As such, Calle's photographs can never offer any authoritative documentation.

In this chapter I also introduce Phillip Auslander's consideration of the performativity of performance documentation and introduce what Rune Gade and Anne Jerslev have described as performative realism. As Gade and Jerslev observe, "becoming a subject today is a question not only of doing rather than being" but also "of being seen doing." ${ }^{25}$ Calle's work highlights and intertwines the acts of being, doing, and seeing.

Suite vénitienne sets up the rhetoric of the detective story in a number of ways. At the very start of the project Calle describes the contents of her suitcase in which the props (wig, dark sunglasses, etc.), are ones of disguise in an attempt to pursue and photograph her subject unnoticed. Wagstaff, Weintraub, and Sante even suggest that Calle's projects offer an element of parody, linking her props to B-movies (Weintraub) and comic books or the photo-novella (Wagstaff). Her writing also includes descriptions that clearly align it with the detective genre: "my investigation," "the gathering of facts," etc.

\footnotetext{
${ }^{124}$ Martha Buskirk quoted in Gratton, "Illustration Revisited: Phototextual Exchange and Resistance in Sophie Calle's Suite vénitienne," 150.

${ }^{125}$ Rune Gade and Anne Jerslev, "Introduction," in Performative Realism: Interdisciplinary Studies in Art and Media (Denmark: Museum Tusculanum Press, 2005), 7.
} 
Calle even has "informants": "Sunday February 17, 2pm: We go to La Madonna restaurant. I tell Jean that I am looking for a friend vacationing in Venice, that I'd like to surprise him. I show him a photo of Henri B that I took on the streets of Paris. Jean promises to let me know." 126

Calle's photographs are also often linked with metaphors and tropes associated with the detective genre or, more specifically, with forensic evidence because they often mimic crime scene photos. ${ }^{127}$ Luc Sante even argues that "her work suggests the forensic process during a police investigation: she assembles clues, descriptions, guesses, allusions and pieces them together into an appropriate rendering." ${ }^{128}$ And Yve-Alain Bois extends the metaphors of detection to the way that Calle takes photographs: "Calle's not interested in photography, per se, she's an apprentice sleuth." ${ }^{129}$

In both Suite vénitienne and The Detective, the photographs exploit the rhetoric of the documentary photograph by imitating certain codes associated with surveillance photography such as grainy black and white film stock, high contrast images, and subjects framed as if caught rather than posed since they

\footnotetext{
${ }^{126}$ Calle, Suite vénitienne, 91.

${ }^{127}$ Krauss highlights the way in which Calle's "collection of evidence" usually leads us back to the author. She is speaking of Calle's 2007 project, Take Care of Yourself, a project in which Calle asked 107 women to interpret and/or analyze a break up letter she received in an email from a lover, Krauss writes "The way the piece seems to refer back to her technical support is that as you are listening and watching these readings of the letter, you're kind of wondering who the writer could possibly be, and of course you come to the conclusion that it's Sophie Calle herself, and that there's a sort of irony in that her work is always about finding a missing other, and in this case, the missing other is herself. But not in a sort of autobiographical way, it's rather this forensic model. Rosalind Krauss, "In Conversation: Rosalind Krauss and Yve-Alain Bois," The Brooklyn Rail: Critical Perspectives on Arts, Politics and Culture, February $1^{\text {st }}, 2012$. http://www.brooklynrail.org/2012/02/art/rosalind-krauss-with-yve-alain-bois (accessed August 19, 2013).

${ }^{128}$ Luc Sante, "Sophie Calle's Uncertainty Principle," reprinted in Sophie Calle: The Reader (London: The Whitechapel Gallery, 2009), 73.

${ }^{29}$ Yve-Alain Bois, "Character Study," reprinted in Sophie Calle: The Reader (London: The Whitechapel Gallery, 2009), 85.
} 
are often seen in motion, blurred, behind doors and windows, etc. (figure 14, figure 15). These two projects reproduce a particular kind of photograph, one that we associate not only with surveillance photography, but also authenticity (one wrapped up in notions of truth and objectivity).

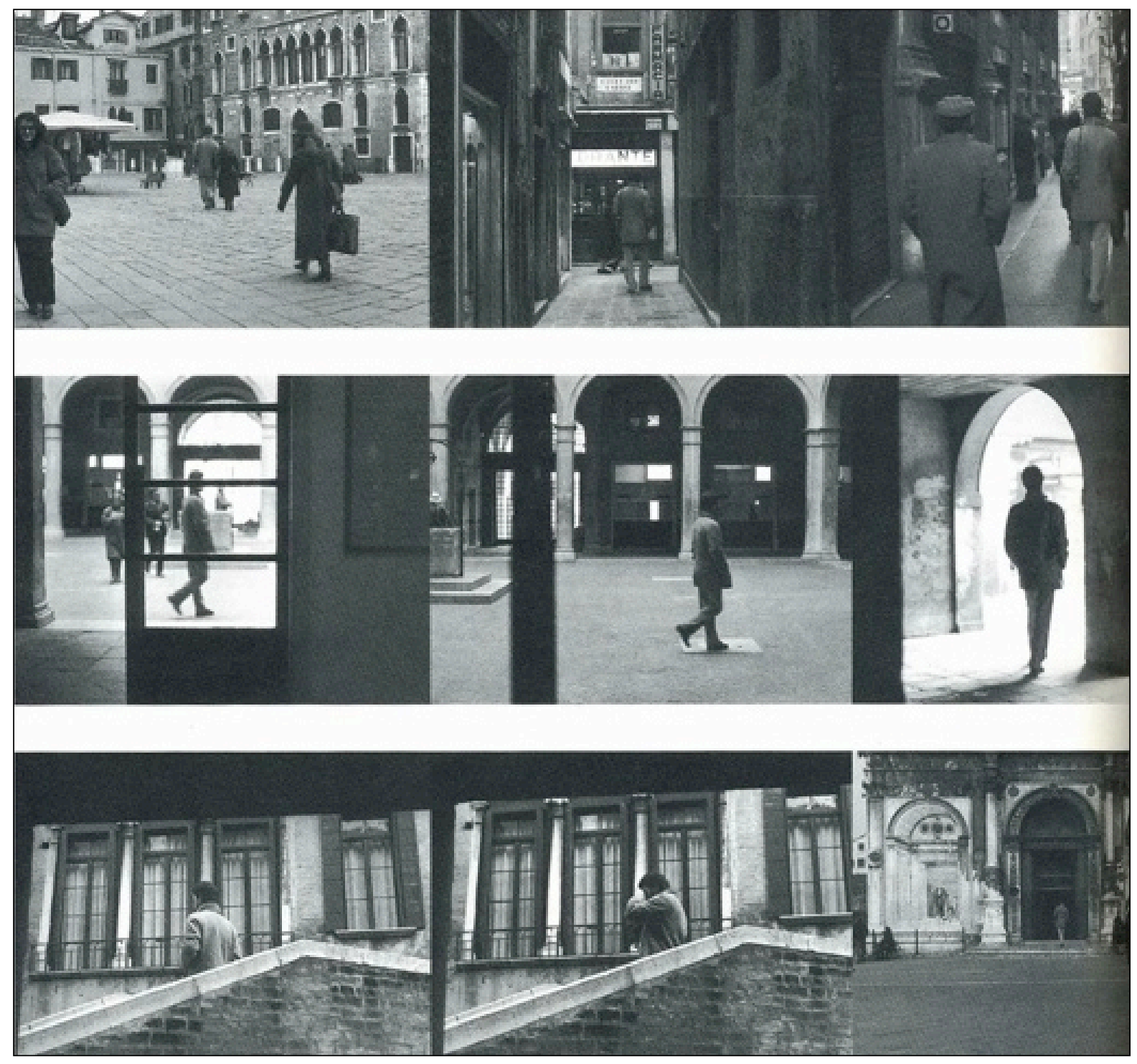

Figure 14. Calle, Suite vénitienne, Double Game, 102. 


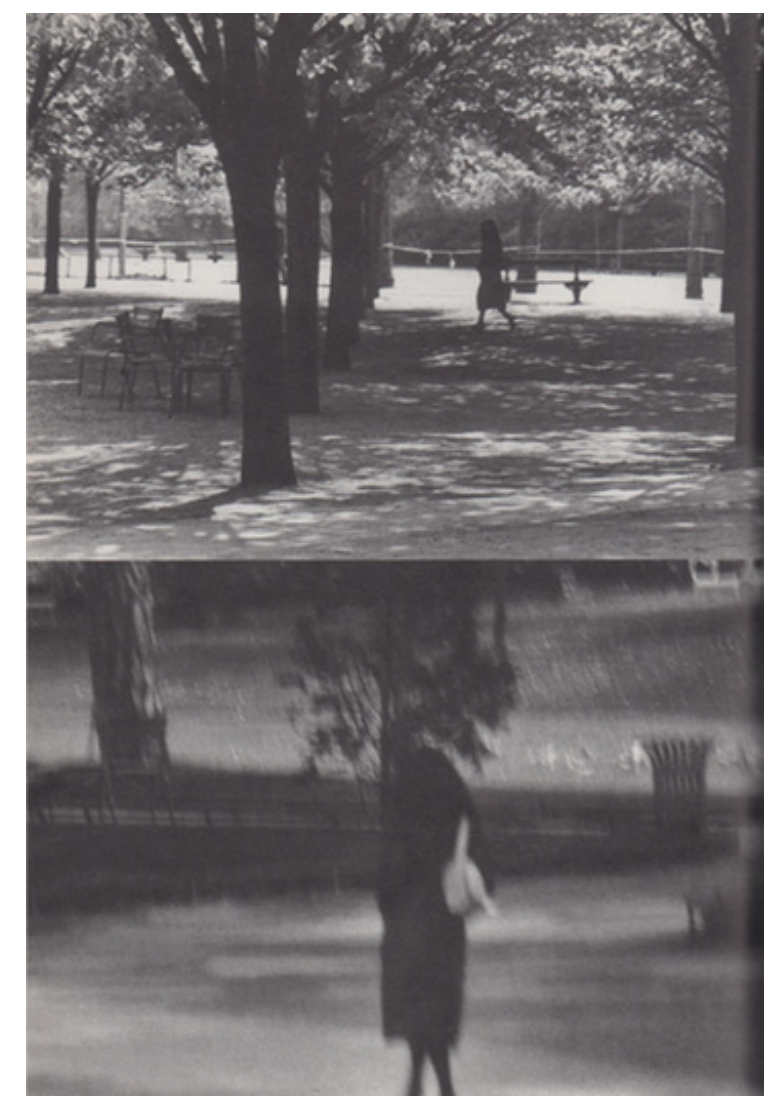

Figure 15. Calle, The Detective, Double Game, 130.

However, Calle's use of autofiction in these projects, and throughout Double Game, sets up certain tensions between what we are told is being photographed and what is actually photographed, producing a certain instability that asks us to question the relationship of the document(s) to the narrated event. As performance archive, Double Game stresses the unstable, constructed, and relational aspect of the archive as it constructs its subject, a change already acknowledged by Terry Cook who purports that the concept of the archive has experienced "a "shift away from the viewing of records as the 
passive products of human or administrative activity and towards considering records as active agents themselves...."130

Cook writes:

Nothing is neutral. Nothing is impartial. Nothing is objective. Everything is shaped, presented, represented, re-presented, symbolized, signified, signed, constructed by the speaker, photographer, writer, for a set purpose.

$[\ldots]$

Texts (which include images) are all a form of narration more concerned with building consistency and harmony for the author, enhancing position and ego, conforming to organization norms and rhetorical discourse patterns, than they are evidence of acts and facts, or juridical or legal frameworks. And there is not one narrative in a series or collection of records, but many narratives, many stories, serving many purposes for many audiences, across time and space. ${ }^{131}$

This relational activity and meaning making encouraged by the archive is also articulated by Yve-Alain Bois who writes that Calle's work "has often deliberately confused levels of reality—or, more precisely, it has transformed reality (the archive) into fiction (narration) and vice versa." ${ }^{\text {132 }}$

\section{The Photograph and The Performance}

In her article on Calle's Suite vénitienne Janet Hand suggests that Calle's photographs sit somewhere between the "documentary" photograph and the "staged" photograph, and argues that by recontextualizing "the documentary photograph as an art object," Calle's work underscores links between recording and representation, between "representational fiction and documentary

\footnotetext{
${ }^{130}$ Terry Cook, "Archival Science and Postmodernism: New Formulations for Old Concepts," Archival Science, no. 1(2001): 4.

${ }^{131}$ Ibid, 7.

${ }^{132}$ Bois, "Character Study," 85.
} 
'evidence'." ${ }^{133}$ This movement between two oppositional understandings of the photographs in Calle's work is reiterated by many authors, such as Patrick Frey, who notes that Calle's photographs are somewhere between the "hyper-real and the hyper-fictional. ${ }^{134}$ But what does this mean for performance art documentation?

Often, in the case of performance art, the photographic image has come to stand in for a much longer and more complex activity. Work like Carolee Schneemann's Interior Scroll (1975) and VALIE EXPORT's Action Pants/Genital Panic (1969) immediately stand out as examples of how the iconic static image circulates as knowledge about the performance (figure 16, figure 17). We thus only ever know these performances through their documentation, and our relationship to the performance is always understood as mediated through the photograph. Authenticity, reliability, and a certain fixedness become associated with the photographic image as it is continually reproduced and comes to stand in for our own understanding of the performance. We no longer read these images as we might read other photographic images, instead accepting that they are to be read as a sign of the performance they are authenticating.

\footnotetext{
133 Janet Hand, "Sophie Calle's Art of Following," Cultural Geographies no.12 (2005): 472.

${ }^{134}$ Patrick Frey, "Tombstones Inscriptions Photographs Captions: The Hyperfiction of Life and Death," reprinted in Sophie Calle: The Reader (London: The Whitechapel Gallery, 2009), 68.
} 

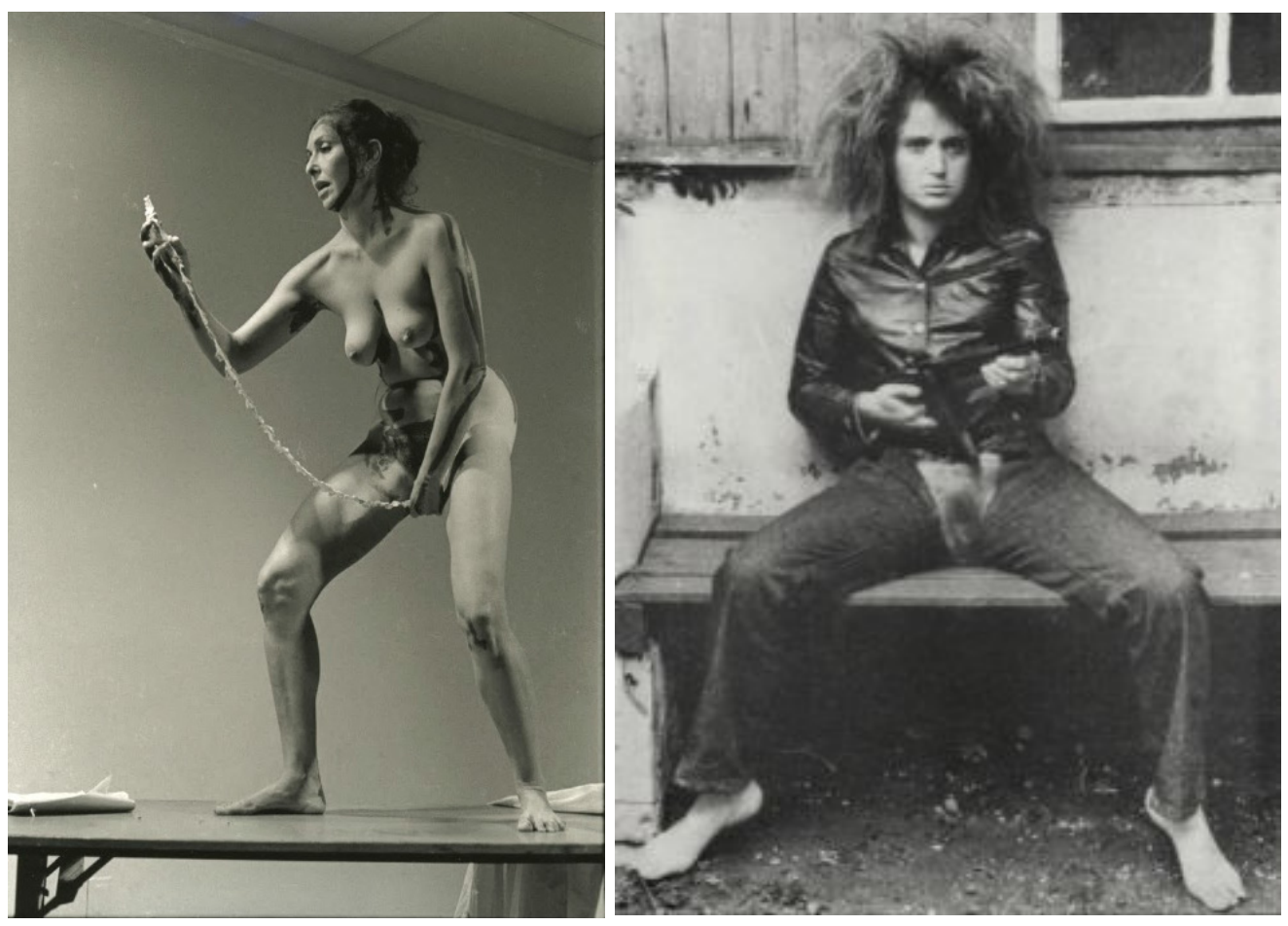

Figure 16. Carolee Schneemann, Interior Scroll, 1975. Photo: Anthony McCall. Source: Elizabeth A. Sackler Center for Feminist Art, Brooklyn Museum http://www.brooklynmuseum.org/eascfa/dinner_party/view_interior_scroll.php (accessed Sept. 22, 2014)

Figure 17. VALIE EXPORT, Action Pants/Genital Panic, 1969. Photo: Peter Hassmann

Source: Artnews.org http://artnews.org/augarten/?exi=24468 (accessed Sept. 22, 2014)

We already understand that there is no possible recovery of these performances, no return to the moment of origin, yet there still continues to be a desire for authenticity and reciprocity between the performance and the photograph. As performance art historian Amelia Jones has argued, "The body art event needs the photograph to confirm its having happened; the photograph needs the body art event as an ontological 'anchor' of its indexicality." ${ }^{135}$ This mutual supplementarity undermines, as Auslander states, "the performance's

135 Jones, “'Presence' in Absentia: Experiencing Performance as Documentation,"16. 
status as the originary event by undoing the priority granted to the performance and suggesting instead, the mutual dependence of performance and document." ${ }^{136}$

But as Martha Buskirk accentuates, there has been and is always already an "uneasy" relationship between performance art and the photograph. Buskirk is most concerned with the kind of evidence that a photograph can provide. ${ }^{137}$ Calle's work relies on photography's embedded history as truth and as record. As Okwui Enwezor stresses in his essay for his exhibition Archive Fever, "every film is a priori an archival object."138 "Photography," Enwezor states, is simultaneously "the documentary evidence" and "the archival record." ${ }^{139}$

However, as Amelia Jones, in speaking about performance photographs, has argued, the photograph, as "proof" that a specific action took place, "is founded on belief systems similar to those underlying the belief in the 'presence' of the body-in-performance.." ${ }^{140}$ And Kristine Stiles, noted by Jones, has also argued that the photograph does not confirm that some previous "real event" has taken place. Stiles states that we cannot ignore "the contingency of the document not only to a former action but also to the construction of a wholly

\footnotetext{
${ }^{136}$ Auslander, "Toward a Hermeneutics of Performance Art Documentation," 93.

${ }^{137}$ Martha Buskirk, The Contingent Object of Contemporary Art (Cambridge, Massachusetts; London England: The MIT Press, 2003), 220.

${ }^{138}$ Okwui Enwezor, "Archive Fever: Photography Between History and Monument," in Archive Fever: Uses of the Document in Contemporary Art (New York; Göttingnen Germany: International Centre for Photography and Steidl Publishing, 2008), 12.

139 lbid., 2 .

140 Jones, “'Presence' in Absentia: Experiencing Performance as Documentation," 15.
} 
fictive space." ${ }^{141}$ It is not only this fictive space of the photograph that I focus on here, but the strategies employed in these projects that help merge the relationship between the "truth" of the performance and its fictionality.

By highlighting this relationship between performance and documentation in Calle's work I write against critics like Robert Pincus, who argues that Calle is "not interested in documentation," and Sheena Wagstaff, who writes that Calle's work "does not present documentation of performances." ${ }^{142}$ Instead, these critics argue that the "work" is the final arrangement of text and photographs. However, by reading these final arrangements in the book as performance remains I propose a more fluid relationship between the performance and its residue. ${ }^{143}$ By making obvious the understanding that photographs do not record reality, but rather construct reality—like autofiction-Calle's projects speak not only to the possibilities for meaning making provided by the photographs, but also stress how the photographs bring forth and open up possible relations between the viewer and the imagined event.

\section{Suite vénitienne}

Buskirk, Gratton, and Hand all relate Calle's following works to Vito Acconci's

\footnotetext{
${ }^{141}$ Kristine Stiles quoted in Jones, "Presence' in Absentia: Experiencing Performance as Documentation," 16. Kristine Stiles, "Performance and its Objects," Arts Magazine 65, no. 3 (November 1990): 35.

${ }^{42}$ Robert Pincus, "Sophie Calle: The Prying Eye," reprinted in Sophie Calle: The Reader (London: The Whitechapel Gallery, 2009), 29; Sheena Wagstaff, "Such is my pleasure, Such is my will," reprinted in Sophie Calle: The Reader (London: The Whitechapel Gallery, 2009), 34.

${ }^{143}$ It is only critic Kate Ince who acknowledges the performative aspects of Calle's projects. She writes, "The phototextuality of the volumes of Double-jeux is the product of her time-based performances." Kate Ince, "Games with a Gaze: Sophie Calle's Postmodern Phototextuality," in The Art of the Project: Projects and Experiments in Modern French Culture, eds. Johnnie Gratton and Michael Sheringham (Oxford and New York: Berghahn Books, 2005), 111.
} 
Following Piece (1969). Acconci's Following Piece is subtitled: "Activity, 23 days, varying locations, New York City." His parameters of the project, similar to Calle's "rules of the game," state: "Choosing a person at random, in the street, any location, each day. Following him wherever he goes, however long or far he travels. (The activity ends when he enters a private place-his home, office, etc.,)." ${ }^{144}$ When exhibited, Acconci's Following Piece consists of twenty-three hand written index cards, one for each day, providing daily written accounts of Acconci's activities. Only four photographs accompany these index cards.

For Janet Hand, Acconci's photographs are a record of the performance, which she considers the "work," whereas in Calle's projects Hand contends that it is the photographs that are the "work," rather than the performance. ${ }^{145}$ I aim to provide a more fluid understanding of Calle's work, one in which the act of following is intimately tied to the documents and cannot easily be separated, although this link does not prove that the events seen and described in the photograph actually happened. I stress instead the uncertainty of the photograph.

In order to position Calle's photographs more precisely, I want to unpack Buskirk's and Gratton's discussions of Suite vénitienne. Buskirk begins her discussion of Calle's project by looking closely at the four photographs in Acconci's Following Piece that are exhibited with the index cards. The photographs depict a man in dark trousers, wearing a short-sleeved shirt. All

\footnotetext{
${ }^{144}$ Vito Acconci, Following Piece (1969), reprinted in Lucy Lippard, Six Years: The DeMaterialization of the Art Object from 1966-1972 (Berkeley and Los Angeles, California: University of California Press, 1997 (1973)), 117.

${ }^{145}$ Hand, "Sophie Calle's Art of Following," 473.
} 
four photographs feature both the man being followed, as well as Acconci following, and are taken not only from behind, but also from the front as the two individuals walk, seemingly unaware, towards the camera (figure 18). For Buskirk, this movement of the photographer (Elizabeth Jackson) offers "strong internal indications that this particular instance has been staged." ${ }^{146}$ Buskirk also notes that none of Acconci's accounts on the index cards actually describe the man seen in the photographs. ${ }^{147}$

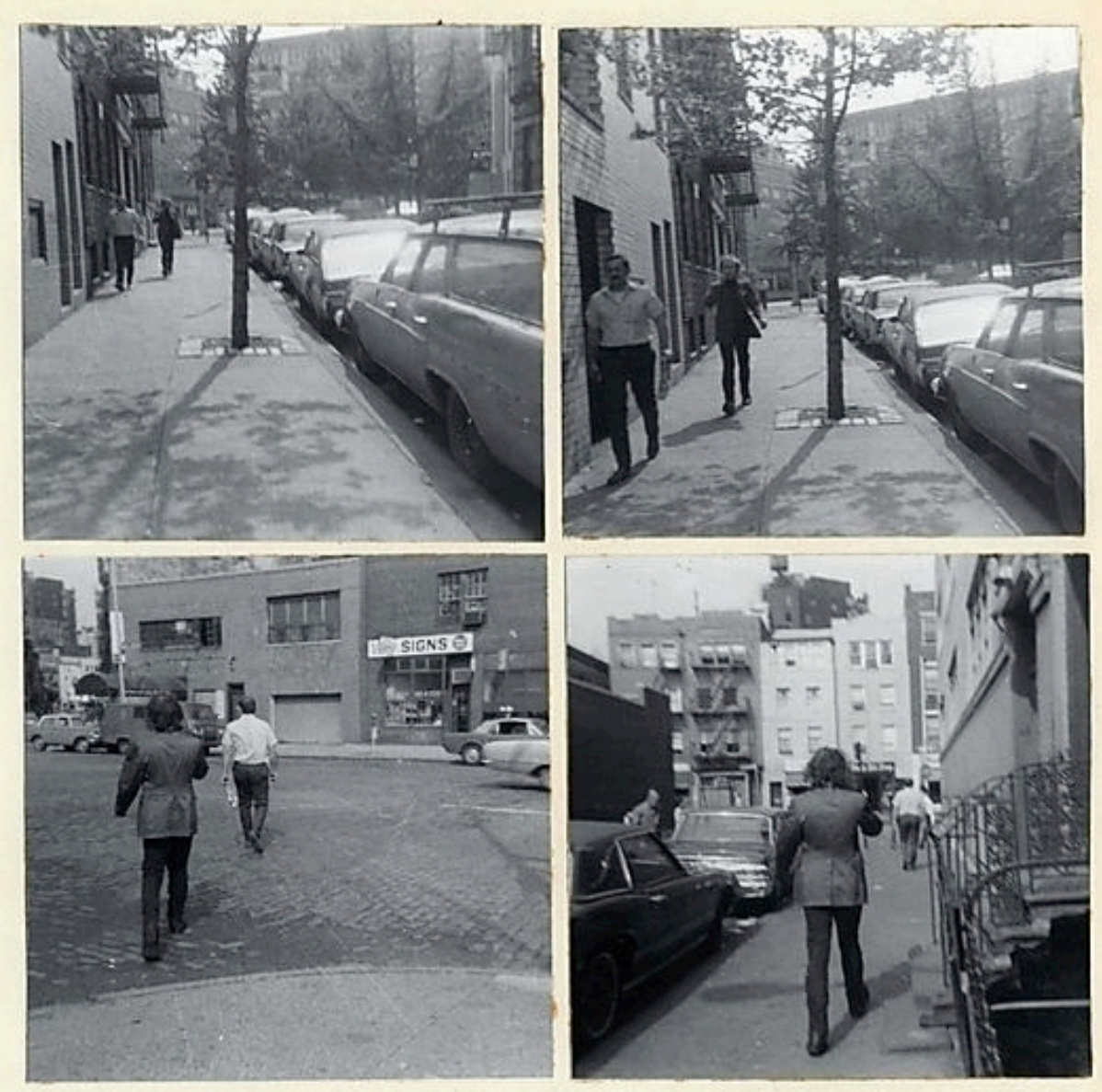

Figure 15. Vito Acconci, Following Piece, 1969.

Source: Metropolitan Museum of Art, http://www.metmuseum.org/collection/thecollection-online/search/283737 (accessed Sept. 22, 2014)

\footnotetext{
${ }^{146}$ Buskirk, The Contingent Object of Contemporary Art, 219.

${ }^{147}$ Ibid., 221.
} 
For Buskirk, the description of the project does not correspond with the photographic "evidence," as Acconci's photographs fail to authenticate the actions described in the text and are thus, according to Buskirk, better understood as "illustration" (rather than "evidence"). ${ }^{148}$ Like Jones and Stiles, however, Buskirk also understands that "even plausible photographs" are not "definitive proof" that an activity took place. ${ }^{149}$

Buskirk also directly addresses Calle's Suite vénitienne and The Detective, asking more specific questions about the relationship of the photograph to the activity. She argues that both of these projects not only play with notions of observer/participant, but also present photographs that "could be evidence of a fictional construction." 150 She asks: "Does it matter whether a photograph actually documents the activity that it represents?"151

This question is addressed directly in Phillip Auslander's important essay, "The Performativity of Performance Documentation." Auslander looks at the iconic images of Chris Burden's Shoot (1971), where Burden was shot in his left arm by his assistant at F-Space Gallery in Santa Ana, California, and at Yves Klein's Leap into the Void (1960), in which Klein is seen leaping off a building into the street. Auslander asks: "What difference does it make to our understanding of these images in relation to the concept of performance documentation that one documents a performance that 'really' happened while

\footnotetext{
${ }^{148}$ Ibid., 221-223. Buskirk argues that the iconic image we associate with Acconci's Seedbedof Acconci under the wooden platform-is actually disconnected from the experience of the viewer for Acconci would have been hidden from sight-thus this iconic photograph is another example of a form of illustration.

149 lbid., 221,

150 Ibid., 223.

${ }^{151}$ Ibid.
} 
the other does not?"152 Auslander asserts that "the act of documenting an event as a performance is what constitutes it as such."153 Auslander writes: "we cannot dismiss studio fabrications of one sort or another from the category of performance art"-even if the event never occurred. ${ }^{154}$

It is important to note that Auslander is building on J.L Austin's speech act theory in which a performative utterance constitutes an action in itself: "to utter a sentence... is not to describe my doing... it is to do it." ${ }^{155}$ It does not describe the action; it is the action. Aulander takes Austin's concept of performativity and applies it to performance documentation: "the traditional view sees performance documents as constatives that describe performances and state that they occurred. I am suggesting that performance documents are not analogous to constatives, but to performatives: in other words, the act of documenting an event as a performance is what constitutes it as such." ${ }^{156}$ Auslander is also writing in part against Peggy Phelan's concept of performance as a unique and spontaneous event in the present tense that cannot be repeated or recorded. ${ }^{157}$ Auslander's repositioning of the performance document serves to disrupt the ontological relationship in which performance is considered to have an autonomous existence prior to its documentation. According to Auslander, Klein's leap "records an event that

\footnotetext{
${ }_{152}^{15}$ Auslander, "The Performativity of Performance Documentation," 1.

153 Ibid., 5.

${ }^{154}$ Auslander, "The Performativity of Performance Documentation," 7.

155 J.L. Austin, How to do Things With Words, Second Edition (Cambridge, Massachusetts: Harvard University Press, 1962), 6.

${ }^{156}$ Auslander, "The Performativity of Performance Documentation," 5.

${ }^{157}$ Peggy Phelan, "The Ontology of Performance: Representation without Reproduction," in Unmarked: The Politics of Performance (London and NewYork: Routledge, 1993), 31.
} 
never took place except in the photograph itself." ${ }^{158}$ Klein's document is, in Auslander's words, "best understood not as a secondary representation of a prior event but as a performance in itself that takes place in a representational space. ${ }^{159}$

Auslander claims that documentation has been conceived of in two ways, one he calls documentary, where the event precedes and thus, authorizes its documentation, and the other he calls theatrical: "These are cases in which performances were staged solely to be photographed or filmed and had no meaningful prior existence as autonomous events presented to audiences. The space of the document (whether visual or audiovisual) thus becomes the only space in which the performance occurs." 160

As Matthew Reason has argued, documentation becomes the "secondary discourse" of performance ${ }^{161}$ Debates about what constitutes Calle's "work" reveal this (inter)dependence as performance and documentation become mutually entangled. I propose that Suite vénitienne and The Detective work towards collapsing the space between the event and its documentation.

In a more recent article on Sophie Calle's Suite vénitienne, Gratton builds on Buskirk's notion that Calle's photographs must be understood as illustration. What draws me to Gratton's discussion is that at the very end of his essay he quotes Auslander's text: "It may well be that our sense of the

\footnotetext{
${ }^{158}$ Auslander, "The Performativity of Performance Documentation," 2.

${ }^{159}$ Auslander, "Toward a Hermeneutics of Performance Art Documentation," 94.

${ }^{160}$ Auslander, "The Performativity of Performance Documentation," 2. Auslander uses Klein and Burden's photographs to demonstrate his division of theatrical and documentary photographs. In the end, however, he states that, "At the phenomenal level, there is not necessarily any intrinsic way of determining whether a particular performance image is documentary or theatrical." Ibid.,8.

${ }^{161}$ Reason, Documentation, Disappearance and the Reproduction of Live Performance, 231.
} 
presence, power, and authenticity of these pieces derives not from treating the document as an indexical access point to a past event but from perceiving the document itself as a performance that directly reflects an artist's aesthetic project or sensibility and for which we are the present audience."162

Gratton compares the notes and photographs from Suite vénitienne to a grouped collection of photographs from Calle's Journaux intimes, which is included in the catalogue from the Pompidou Centre (figure 19, figure 20). This diary contains photographs and notes of Calle's following projects, including Suite vénitienne. Gratton remarks, for example, that the diary version is much shorter and less detailed in its timing of events, and that Calle's subject is initially named DH not Henri B. But more importantly for Gratton, it is a photograph included in Calle's Journaux intimes of a man who is different from the one included in the final project on which he focuses his attention: the man is wearing a darker coat and his hairstyle is different (figure 21). ${ }^{163}$

\footnotetext{
${ }^{162}$ Phillip Auslander quoted in Johnnie Gratton, "Illustration Revisited: Phototextual Exchange and Resistance in Sophie Calle's Suite vénitienne," 163. Auslander, "The Performativity of Performance Documentation," 9.

${ }^{163}$ Gratton, "Illustration Revisited: Phototextual Exchange and Resistance in Sophie Calle's Suite vénitienne," 153.
} 

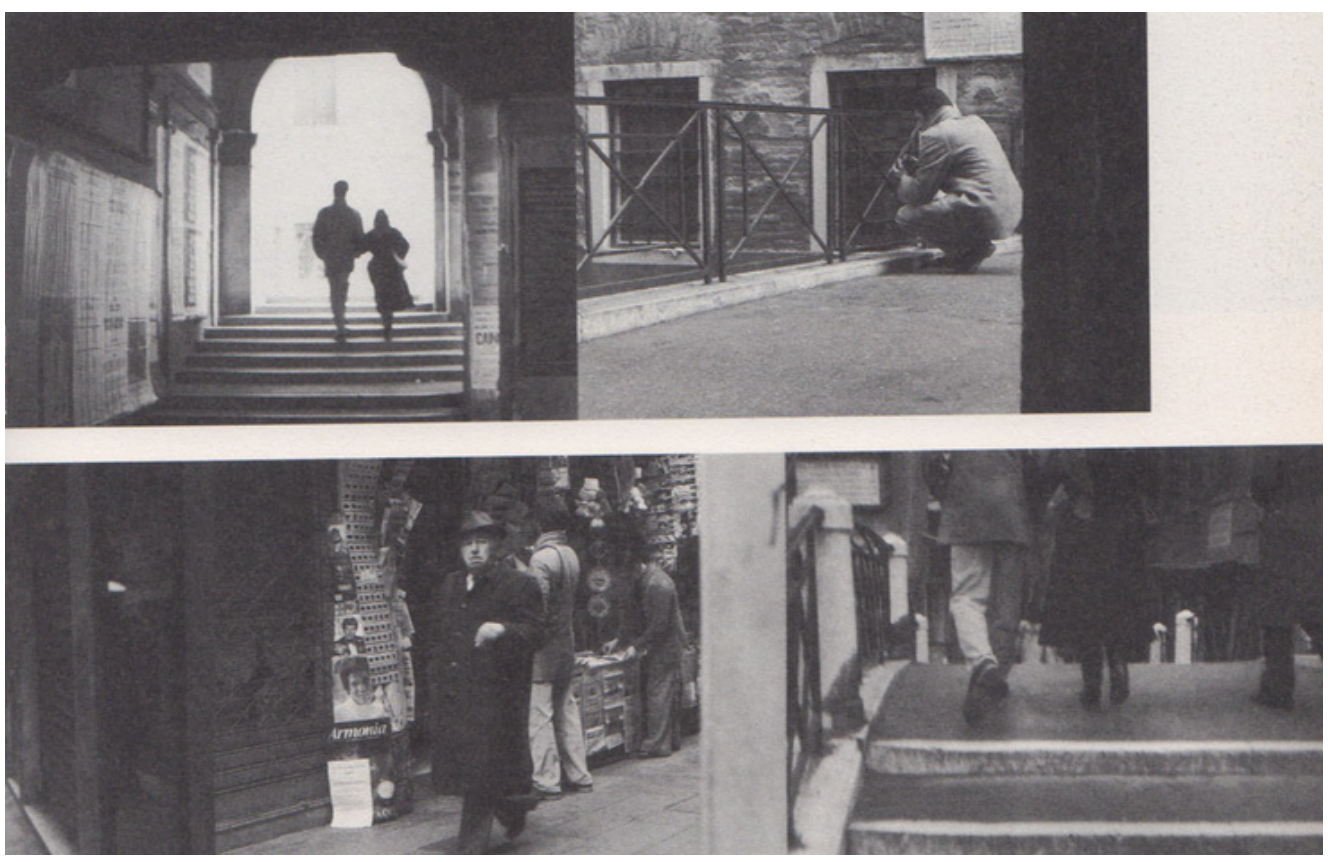

Figure 19. Calle, Suite vénitienne, Double Game, 93.

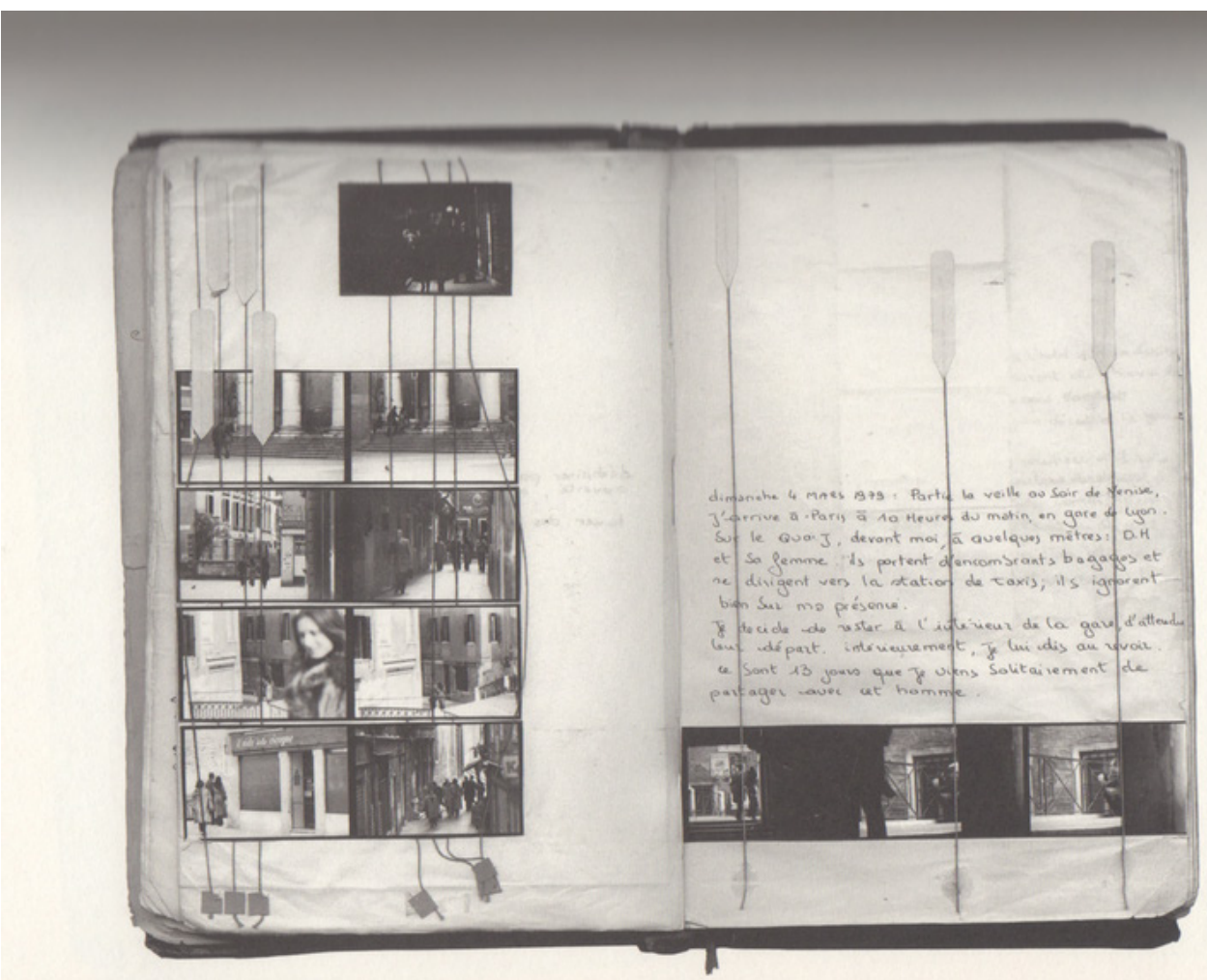

Figure 20. Calle, Paris Shadows, Excerpts from Calle's Diaries. Source: Sophie Calle, M'as-tu-vue? (Munich, Berlin, London, New York: Prestel, 2003), 69. 


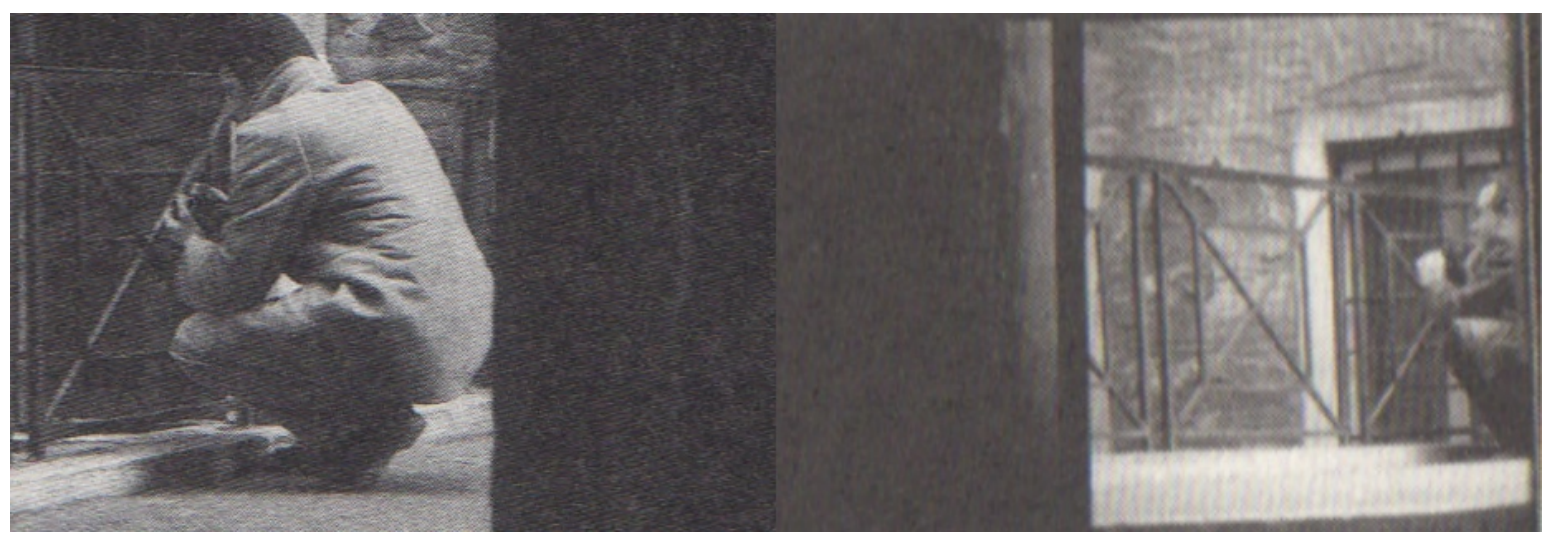

Figure 21. Detail. Calle, Suite vénitienne, Double Game, 93; Detail. Calle, Paris Shadows, Excerpts from Calle's Diaries, Sophie Calle, M'as-tu-vue, 69.

\section{The Double}

It is Jean Baudrillard's essay entitled "Artificiality and Seduction" that helps us understand this discrepancy. Baudrillard, who wrote the accompanying essay for Calle's Suite vénitienne, discusses Calle's project with Marc Guillaume. Baudrillard notes that Calle's use of doubling is not only through making herself into "this man's shadow," but references another kind of doubling, as return and repetition: "To publish the book, she had to return to Venice with a couple of friends and retake all the pictures in the same spots. Not only did the man become an Other in the sense that she was following him-the absolute Other—but there has to be a second installment where he was not only followed but replaced by a double like in the movies." ${ }^{164}$

Thus for Gratton, the images post-date the project and help demonstrate, like the photographs in Acconci's Following Project, that the images were

\footnotetext{
164 Jean Baudrillard and Marc Guillaume, "Artificiality and Seduction," in Radical Alterity, trans. Ames Hodges (Los Angeles: Semiotexte, 2008, 1994), 125.
} 
staged, and therefore must be regarded as illustration rather than "evidence." Speaking of Acconci's photographs, Gratton writes: “We read 'something' but see only something similar, something that, in its very similarity, is thereby something 'else,' other, extraneous to the text." ${ }^{\text {166 }}$ This underlines, I suggest, the importance of the photograph as supplement. ${ }^{167}$

Gratton also highlights the temporal gap between text and image that is often seen in biographical and autobiographical works, explaining that photographs are usually inserted after the text is written, yet predate the text, and thus conform to the temporal delay associated with illustration. ${ }^{168}$ However, Calle's projects often play with the linear unfolding of events, and her texts move between present and past tenses. It often seems as though the text is written after the events have come to pass. In Double Game, the projects are not arranged in chronological order, nor according to the unfolding of events in Auster's narrative thus Calle's arrangement of the projects within the book offers yet again another version. Gratton suggests that Double Game's "doubleness" is not only due to the interplay between fact and fiction, text and photographs, but also partly due to this interplay between past and present. ${ }^{169}$

\footnotetext{
${ }^{165}$ Gratton, "Illustration Revisited: Phototextual Exchange and Resistance in Sophie Calle's Suite vénitienne," 154.

${ }_{166}$ Ibid., 162.

167 Derrida, "Signature Event Context," 2-4.

168 Gratton, "Illustration Revisited: Phototextual Exchange and Resistance in Sophie Calle's Suite vénitienne," 153-54. Gratton spends some time in this essay focusing on Calle's temporal delay. Suite vénitienne is actually Calle's first project, but in publishing the book version of this project, her lawyer suggested she change the year from 1979 to 1980 (to avoid possible complaints from the man she followed). Yve-Alain Bois also acknowledges this temporal gap in Calle's work, for at the very beginning of his essay on Calle, he writes: "In general, Sophie Calle writes in the past tense...." "Her past only exists through its proof." Bois, "Paper Tigress," 29. ${ }^{169}$ Gratton, "Experiment and Experience in the Phototextual Projects of Sophie Calle," 161.
} 
I propose that autofiction helps account for the temporal disjunctures in Calle's work. In writing about autofiction, Serge Doubrovsky argues: "The classical autobiography is a continuous, historical and logical narrative gathering the meaning of one's own life." ${ }^{170}$ In contrast, "Autofiction can seize on the same facts and events, but assembles them in a radically altered presentation, disorderly or in an order, which deconstructs and reconstructs narrative according to its own logic with a novelistic design of its own." ${ }^{\text {171 }}$ Calle's reconstructions make more obvious this temporal delay through their “disorderly" temporal presentation. Much like Peter Brooks' discussion of Freud's Wolf Man narrative, in which story and plot can be shuffled in many ways, the unfolding of time in these projects is not coherent or linear and emphasizes that both the photographs and the narrative are always already unreliable.

Gratton focuses on the fact that Calle does not divulge this information about having to reshoot the photographs with another Henri B when interviewed by Christine Macel for the Pompidou catalogue, and that this omission would suggest that she does not want to subvert the "documentary" status of the finished work. Again, we are at the crossroads between fact and fiction, the inability to determine one from the other, "evidence" from fabrication. The lack of captions, I argue, underscores this mobility. We are never told that the particular images are of certain places or people. We just assume because of

\footnotetext{
${ }^{170}$ Serge Doubrovsky, "Autofiction," Auto/Fiction 1,1 (July 2013): 1.

${ }^{171}$ Ibid.
} 
their layout that they are proof of the story being told, markers of the events unfolding.

I contend that Calle's photographs never had "documentary" status to begin with, as they are always unreliable and always constructed; this is the autofictional at work. Her "proof" of the acts described is always understood to be a possible fiction, and the disjuncture in time and place draws attention to this undecideability, which also works to destabilize the truth of any autobiographical impulse. Writing about the photographs in both Vito Acconci's Following Piece, as well Adrian Piper's Catalysis III and IV (1970), Buskirk suggests that: "The photographs unexpectedly confirm the status of these actions as essentially unverifiable." ${ }^{172}$ Buskirk argues that their power lies in "the challenge they pose," which is whether to "believe the artists' claims to have done what they describe."173

This relationship of document (representation) to event (enacted) is addressed in Medhtild Wildrich's "Location and Dislocation: The Media Performances of VALIE EXPORT." Wildrich examines EXPORT's iconic photograph of Action Pants/Genital Panic (1969) and suggests that EXPORT's account of the event (one in which she walks through a cinema in crotch-less pants and a leather jacket) "is probably a fiction, since no hint of this performance exists in newspapers or archives; this is in direct contrast to EXPORT's widely circulated Touch Cinema [in which the audience was invited

\footnotetext{
${ }^{172}$ Buskirk, The Contingent Object of Contemporary Art, 221.

${ }^{173}$ Ibid.
} 
to touch EXPORT's breasts as she wore a "theatre" on her chest]." ${ }^{\text {"174 }}$ While I am not convinced by Wildrich's reasoning for considering EXPORT's work as fiction (there may be many reasons that there is no documentation of this event-particularly if it did take place in a dark cinema), what surfaces, as articulated by Amelia Jones, is that the "images mean discursively but in contradiction (or at least in contrast) to what occurred with the physical body and in material spaces at the time...."175

According to Jones, "Genital Panic unfolds as part of a reiterative everexpanding network of meaning-generating ideas, images, and beliefs that themselves relate to an ever metamorphosing concept about what constitutes the 'original' event." 176 Our access, and thus our knowledge of Calle's timebased performances are only through Calle's narrative texts and photographs. As performance documentation, this relationship of the photograph to the event is constantly shifting as we discover more gaps and other stories. The photographs thus refuse both the fixity of the image as interchangeable for the event, and also the fixity of some authentic original moment of enactment, thus highlighting the impossibility of ever retrieving the full event, a complete archive.

In returning to Venice and re-photographing the places she walked, Calle literally retraces her steps with the "body double," again displacing notions of origin and instead emphasizing repetition by exploiting the iterative quality of

\footnotetext{
${ }^{174}$ Widrich Mechtild, "Location and Dislocation: The Media Performances of VALIE EXPORT," PAJ 33, no. 3 (September 2011): 58.

175 Jones, "The Artist is Present': Artistic Re-enactments and the Impossibility of Presence," 30. ${ }^{176}$ Ibid.
} 
her projects—as yet another iteration—as the same but not identical. ${ }^{177}$

In Suite vénitienne there are a series of photographs that are imitations of photos that Calle watches Henri B take in Venice. She attempts to imitate his movements and take the same photographs.

Campo San Polo-he points to the church, takes a picture of the piazza. I imitate him.

Ponte della Madonetta-he crouches to snap a shot of the canal, or perhaps that passing boat? After several seconds, I imitate him, trying my best to take the same picture.

He turns his back to me and photographs a group of children playing. Quickly, I do the same.

Pinte Della Cortesia-he points toward the canal as if to show something to the woman, I take a picture in the same direction. ${ }^{178}$

These photographs are not like the other surveillance images: they are in focus, clear, well framed. They are also the only images with captions, as if Calle wants to locate them in space and emphasize how she physically takes the place and space of Henri $\mathrm{B}$, who is already a replacement for $\mathrm{DH}$, by attempting to see what he sees. I suggest that Calle's picture taking reinforces how Calle makes literal and material slippage between subjects as a way to emphasize the mobility of the autofictional subject (as an endless chain of metonymic replacements).

It is Yve-Alain Bois who argues that Calle's work uses proxy as a

\footnotetext{
${ }^{177}$ Calle often engages repetition in her projects, and often produces the same project in different contexts. The Detective, was repeated twenty years later in a project called Vingts ans après (2001). In this project, Calle "was followed by a private detective of the Duluc agency who ha[d] been hired by Emmanuel Perrotin [her gallerist]." Sophie Calle, Twenty Years Later, Sophie Calle, M'as-tu vue? (Munich, Berlin, London, New York: Prestel, 2003), 113.

${ }^{178}$ Calle, Suite vénitienne, 94-95, 104-105.
} 
strategy for stressing ambiguity. Bois is speaking specifically about her project Les dormeurs (1979), in which she asked strangers to sleep in her bed for the night—literally to take her place—and "when one of the sleepers misses the appointment, she replaces him or her. She takes 'her' place..179 Near the end of Suite vénitienne, Calle wants literally to take Henri B's place: “...I also envision myself taking his room, sleeping in his bed." ${ }^{180}$ Movement between Calle and her subjects is consistent in Calle's work and her use of substitution becomes another strategy for making more obvious the mobility of the autofictional subject. In Double Game we see the movement between Calle and Maria, Calle and Auster, Calle and Henri B, Calle and Bardot, Calle and M, etc. This slippage between subjects, and bodies, extends to the event, representation, and record.

\section{Performative Realism}

In all of Calle's projects, our access to and thus our knowledge of the work are only through her narrative texts and photographs; there was no event to which an audience was invited. We can never know if Calle has "done what she describes." As Gratton acknowledges, Calle's presentation of the events in both the photographs and the text appear seamless in their integration, for it is only when we look outside the text that we discover that the photographs are actually a reiteration of the initial project. In many ways Gratton's investigation parallels Sadoux's concerns regarding autofiction. According to Sadoux, "The main problem with many definitions of autofiction is that they dispense with the

\footnotetext{
${ }^{179}$ Bois, "Paper Tigress," 39.

${ }^{180}$ Calle, Suite vénitienne, 118.
} 
literary process in their effort to define a genre on the basis of the truthfulness of biographical information which lies outside the text." ${ }^{181}$

Rather than attempting to discern between documentary and illustration, or documentary and theatrical photographs, both of which ask that we verify the "truth" of the narrated acts, I propose instead the importance of undecideability: Calle's photographs are both and neither. At the end of his essay, Gratton seems to come to a similar conclusion, highlighting the temporal discrepancy. He writes, "As I have moved through this analysis, it has proved more and more difficult to separate the projects-then from the documents-now, to distinguish documentary material from illustrative material, and even to divide the two projects from each other." ${ }^{182}$ The status of Calle's photograph does not depend on the "truth" of the narration, or the photograph's fidelity to the events as they occurred. In writing about performance documentation Auslander argues: "the truth of performance documentation does not reside in its indexical relationship to the event or in the verifiable accuracy with which it depicts that event." ${ }^{183}$

As in The Chromatic Diet, we understand that the photographs in Suite vénitienne offer a paradox as they move between evidence and illustration, for they account for Calle's movement through Venice, by representing the event as if it had happened as described in her text. In creating a photographic record, Calle appears to highlight the impossibility of the visual evidence to attest to anything more than what we see. Yet their placement in the project, as

\footnotetext{
181 Sadoux, “Angot's Autofictions: Literature and/or Reality?," 175.

182 Gratton, "Illustration Revisited: Phototextual Exchange and Resistance in Sophie Calle's Suite vénitienne," 163.

${ }^{183}$ Auslander, "Towards a Hermeneutics of Performance Art Documentation," 95.
} 
illustration to the story, suggests a more complex operation. As Gratton argues: "... the more we ponder these photographs the more they appear to prompt us to engage in the hermeneutics of suspicion and to envisage them as dubious documents, teetering dangerously on the edge of fiction." ${ }^{184}$ Thus we return to the beginning of my text and the question posed by Buskirk, just what kind of evidence can a photograph provide? What kind of evidence is required of narrative for it to be believable? Not believable? Undecideable?

In a collection of essays entitled Performative Realism: Interdisciplinary Studies in Art and Media, editors Rune Gade and Anne Jerslev introduce the concept of performative realism. In focusing on the intersection between performance and performativity (Austin's performative utterances), the essays collected in this book emphasize the intersection of performance and performativity and reconsider how events are (re)produced and mediated. ${ }^{185}$ Rather than focus on questions of representation, Gade and Jerslev articulate the importance of participation and narration in performative work, including possibilities for meaning making. For Gade and Jerslev, performativity, through its connection to poststructuralism, particularly Roland Barthes, helps collapse oppositions such as fact/fiction, life/art, true/false, private/public. They draw on Roland Barthes' concept of "reality effects" which cause what he describes as "the referential illusion." For Barthes, "Realism operates not through simple denotative 'likeness' but rather a connotative reference to the real as a category. Techniques of citation and repetition are employed to achieve this

\footnotetext{
${ }^{184}$ Gratton, "Illustration Revisited: Phototextual Exchange and Resistance in Sophie Calle's Suite vénitienne," 149.

${ }^{185}$ Gade and Jerslev, "Introduction," 10-11.
} 
effect, a laborious theatre of reiteration because realism, or the reality effect, is first based on recognition on the part of the reader [emphasis mine]." ${ }^{186}$ British performance artist Haley Newman's Connotations_Performance Images (1994-1998) consists of photographs and texts documenting performances that never took place. For example, in Crying Glasses: An Aid to Melancholia, Connotations-Performance Images 1994-98, Newman writes:

Over a year, I wore crying glasses while travelling on public transport in all the cities I visited. The glasses functioned using a pump system which, hidden in my jacket allowed me to pump water up out of the glasses and produce a trickle of tears down my cheeks. The glasses were conceived as a tool to enable the representation of feelings in public spaces. Over the months of wearing the glasses they became an external mechanism which enabled the manifestation of internal and unidentifiable emotions.

The text is accompanied by a photograph of Newman wearing dark glasses with tears streaming down her face (figure 22).

${ }^{186}$ Ibid.,11. 


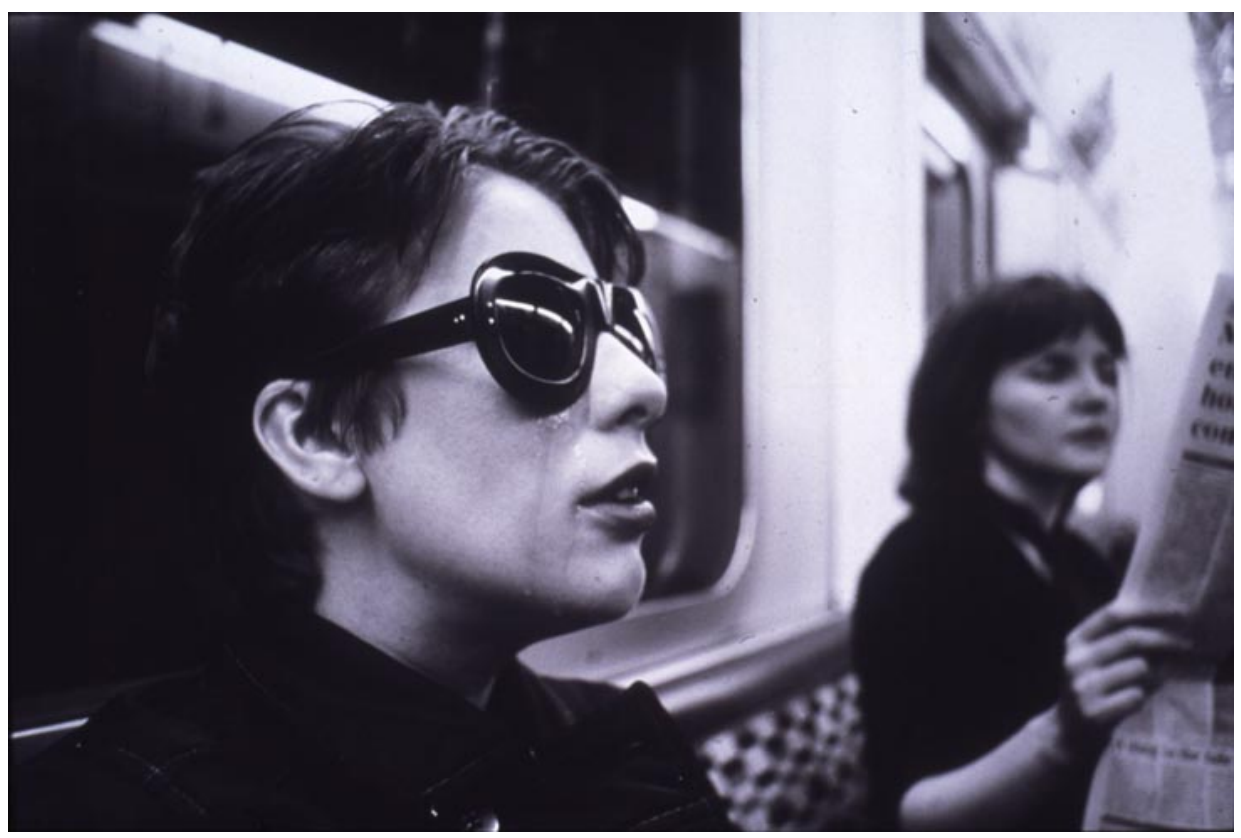

Figure 22. Hayley Newman, Crying Glasses: An Aid to Melancholia, Connotations-Performance Images 1994-98, 1995. Photo: Casey Orr. Source: Saatchi Gallery http://www.saatchigallery.com/artists/artpages/hayley_newman_crying.htm (accessed Sept. 22, 2014)

Newman never performed the actions as noted in her text, but rather created these scenes for the camera with Casey Orr, a photographer. She describes her project, Connotations_-Performance Images 1994-98, as:

constructed images intended to explore the role of documentation in performance. The photographs in the series were staged and performed by myself with most of the images being taken by the photographer Casey Orr over a week in the summer of 1998. The dates, locations, photographers and contexts for the performances cited in the text panels are fictional. In all instances the action had to be performed for the photograph, but did not take place within the circumstances or places outlined in the supporting text. ${ }^{187}$

Included in Gade and Jerslev's book is an essay on Newman by Camilla

\footnotetext{
${ }^{187}$ Hayley Newman, Performance/Connotations_Performance Images 1994 -1998, http://www.hayleynewman.com/artworks/show/15 (accessed April 12, 2012).
} 
Jalving, who describes Newman's work as "producing a certain kind of reality: a reality produced as an effect of a subversive act of repetition." ${ }^{\text {188 }}$ Like Calle's work, Newman's documents foreground the "unstable relationship between performing and documenting, between presenting and representing... between repetition and the unique [original] moment." ${ }^{189}$ Jalving goes on to describe the difference between what is said to have happened and what has happened as a "hall of mirrors." 190

In its book format, Newman's project is included with photographs from other performances that "actually happened." Jalving writes "the reader simply flipping through the book will not immediately know what is 'true' and what is 'false', as the two types of documentation... are linked together in a paradoxical double bind." ${ }^{191}$ Jalving continues, suggesting that the fake documents infect the real documents: "In the sense that the possibility that Newman might be posing undermines the presumed realness of these other documents and thus increases the destabilization of the beholder." ${ }^{192}$ This inability to determine real from fictional, I suggest parallels Calle's Double Game. However, Newman clearly announces the fictionality of her projects, while Calle, instead, highlights the undecideability of her autofictional projects. We are not able to distinguish what was enacted, what the photograph records, and what is said to have happened. But both artists' "documentation" of their performances, I propose,

\footnotetext{
${ }^{188}$ Camilla Jalving, "Inventing Reality: On Truth and Lies in the Work of Hayley Newman," in Performative Realism: Interdisciplinary Studies in Art and Media, eds. Rune Gade and Anne Jerslev (Denmark: Museum Tusculanum Press, University of Copenhagen, 2005), 145.

189 Gade and Jerslev, "Introduction," in Performative Realism, 14.

190 Jalving, "Inventing Reality: On Truth and Lies in the Work of Hayley Newman," 149.

191 Ibid.

192 Ibid.
} 
aims to merge fact and fiction, performance and documentation, presentation and representation.

For Jalving, Newman's photographs are "insistently invented" and "painstakingly falsified." ${ }^{193}$ Art critic Jennifer Doyle describes Newman's photographs in a similar way, as "staged images of fictional performances that never happened." ${ }^{194}$ It is here that the work is enacted, returning us to Auslander's consideration of the performativity of performance documentation. I am suggesting that Calle's work is more fluid than either Buskirk or Gratton acknowledge, as the actions, the narrative, and the images begin to dissolve into one another. The performative act is recorded by the camera, but perhaps not always as described (autofiction).

Calle's photographs enact what Gade and Jerslev describe as performative realism, "a complex means of mediation that co-operate with the bodily signs to produce a theatre of truth, an illusion of referentiality, in which it is impossible to decide whether we are witnessing something real or fictitious." 195 This "illusion of referentiality" is made more obvious in Calle's project The Detective.

\section{The Detective}

In The Detective, Calle asked her mother to hire a detective to follow her: "In April 1981, at my request, my mother went to a detective agency. She hired them to follow me, to report my daily activities, and to provide photographic

\footnotetext{
193 lbid., 150.

194 Jennifer Doyle, "The Strange Theatricality of Tears: Nao Bustamante's Neopolitain (2009)," in Hold it Against Me: Difficulty and Emotion in Contemporary Art (Place: Duke University Press, 2013), 84.

${ }^{195}$ Gade and Jerslev, "Introduction," 11.
} 
evidence of my existence." ${ }^{196}$ The images are arranged in a similar manner to Suite vénitienne, alternating between full-page images, smaller photographs grouped on the page, as well as full-page contact sheets showing multiple shots of the subject being tailed-smaller versions of the photographs we are about to encounter (figure 23). In contrast to Suite vénitienne, however, it is Calle who is the subject of the photographs. In all of the images there is distance that is maintained between the detective and his subject (Calle) and her face is usually turned away from the camera, hidden or blurred. Again the use of the contact page, the grainy quality of the film stock, and the subject on the move, all reiterate the genre of surveillance photography. As in Suite vénitienne, there are no captions.

${ }^{196}$ Calle, The Detective, 122-123. 


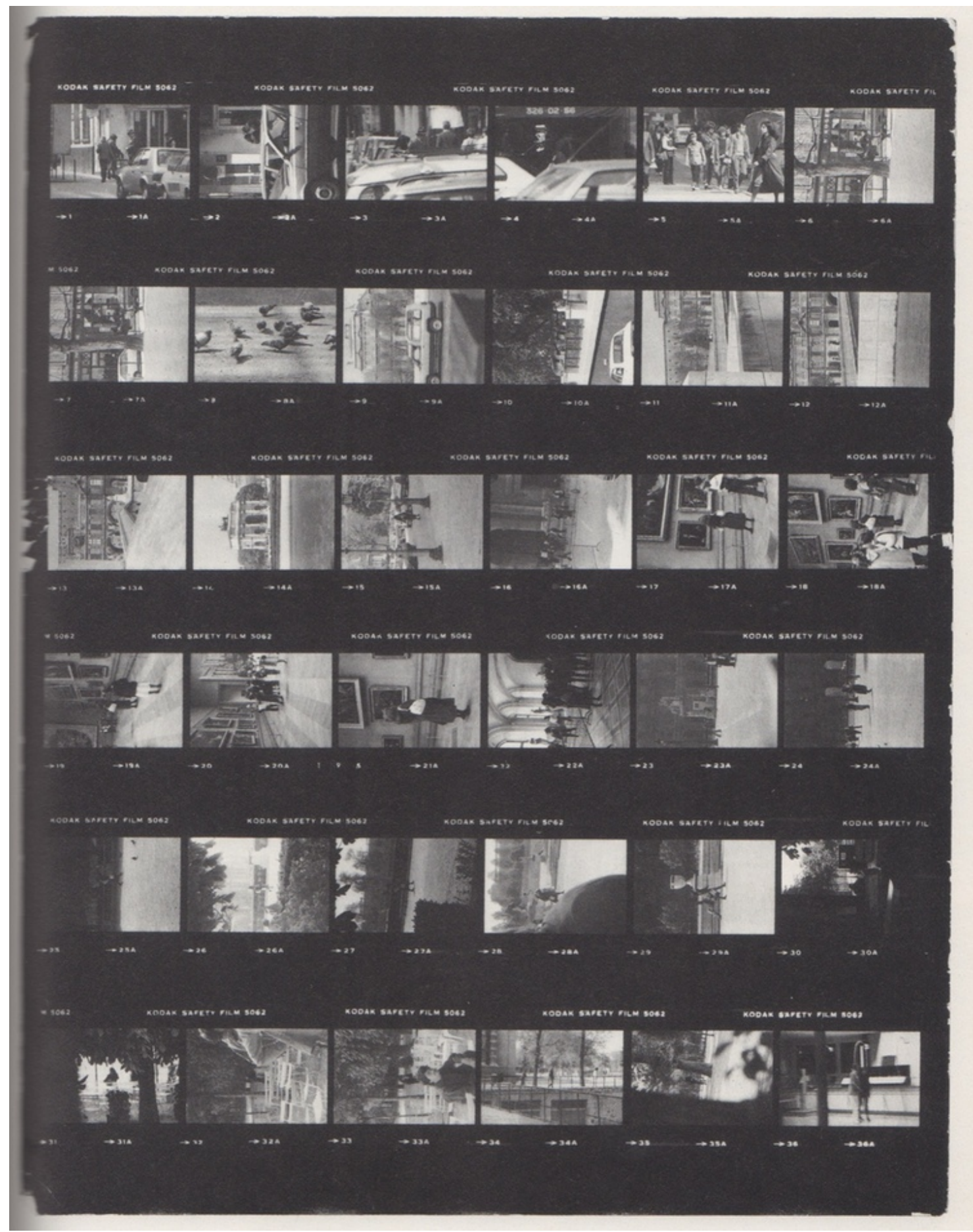

Figure 23. Calle, The Detective, Double Game, 127.

The project begins with a page-length colour photograph (the only one in the project) of Calle in "grey suede breeches, black tights, black shoes, and a 
grey raincoat, over my shoulder a bright yellow bag, a camera" (figure 24). ${ }^{197}$ The body, highlighted in this image, and subsequently the focus in all the detective's photographs, serves to authenticate the work. For as Jones, Gade and Jerslev have all argued, it is the body in performance photography that is understood to ground the work as a trace of the "authentic" and the "reality" that has taken place.

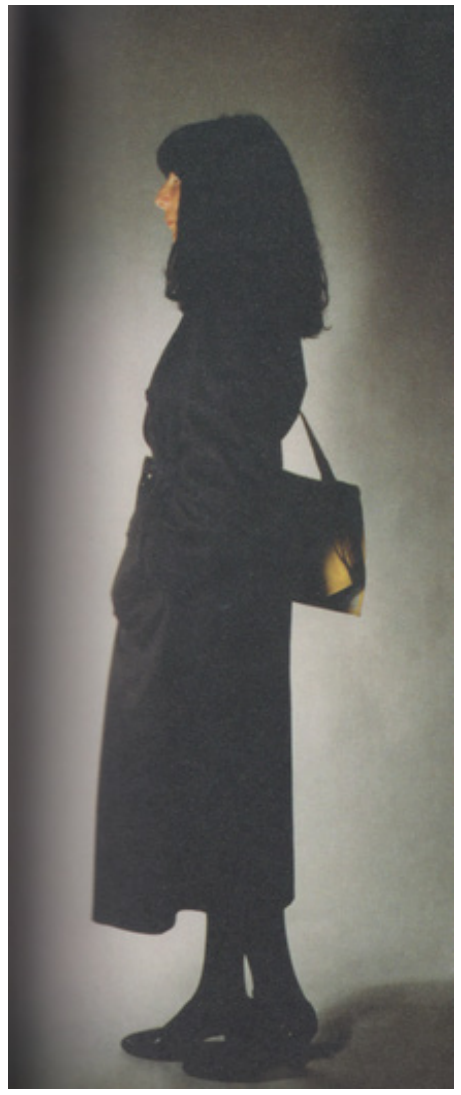

Figure 24. Calle, The Detective, Double Game, 125

The black and white photographs in the project are accompanied by two accounts of the day: one written by Calle and one written by the detective. Calle's account reads like a diary: "At 3:10 PM I leave the Louvre. In the garden

${ }^{197}$ Calle, The Detective, 124. 
of the Tuileries a photographer offers to take my picture with my camera. I accept. At 3:20 PM I stop at the Tuileries' outdoor café and order a beer. I take pleasure in watching 'him' have his drink at the counter." 198 This is followed by the detective's account of the day, which lacks any subjective input: "At 3:10 she leaves the Louvre and crosses the Tuileries. She has herself photographed by a street photographer. At 3:20 the subject takes a drink at the outdoor café in the Tuileries gardens and writes." ${ }^{\text {199 }}$ A photograph of Calle (presumably) seated at a table accompanies this text (figure 25). The leaves of the trees serve to accentuate the distance between the detective and his subject, but also suggest that the observer wants to remain hidden (unseen).

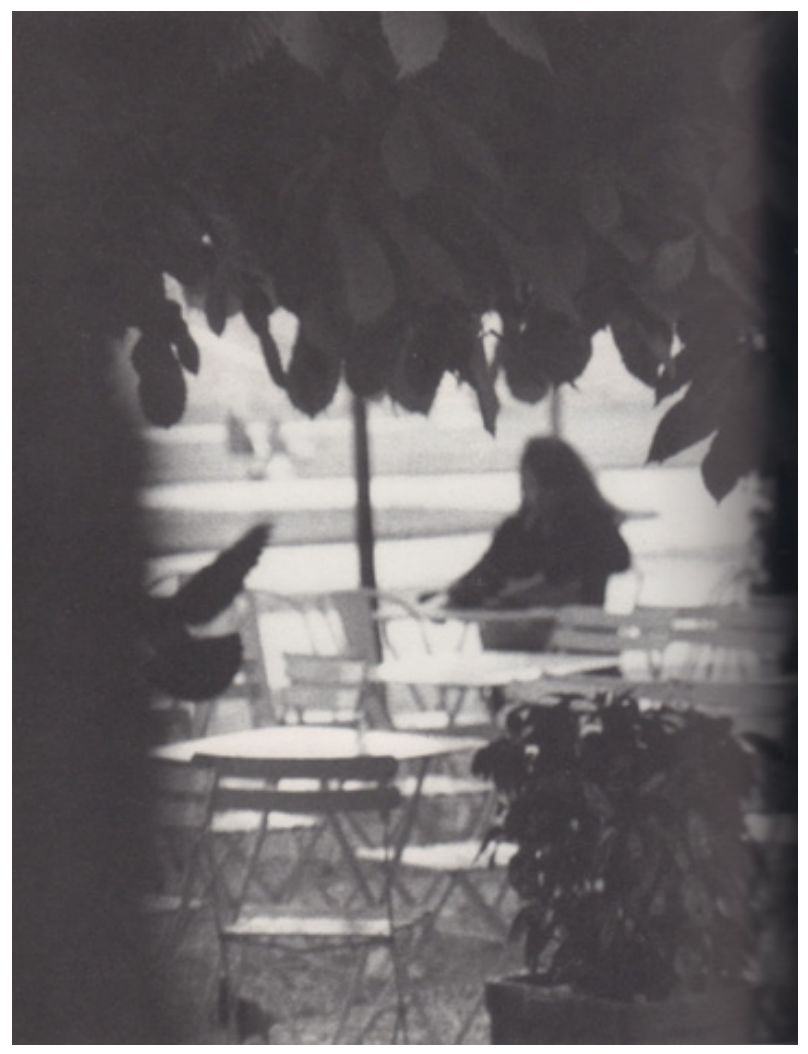

Figure 25. Calle, The Detective, Double Game, 134.

\footnotetext{
${ }^{198}$ Calle, The Detective, 126.

199 Ibid., 133.
} 
But in looking closely at the details of their accounts we notice gaps and inconsistencies. In the very beginning Calle writes: "I take rue Gassendi and buy marigolds for eight francs at the flower shop. I enter Montparnasse cemetery and lay them on Pierre V's grave, b. 1921 d. 1981 [emphasis mine]." ${ }^{200}$ In the detective's account he writes: "At 10:23 the subject buys some daffodils at the florist's on the corner of rue Froidevaux and rue Gassendi, then enters Montparnasse cemetery at 5 rue Emile-Richard. She lays the flowers on a tomb then leaves the cemetery...[emphasis mine]." ${ }^{201}$ Perhaps the detective, who describes the flowers as daffodils, does not know his flowers, but just two entries later he writes: "At 10:40 she enters 100 boulevard Montparnasse. At $11: 32$ the subject comes out of the building in the company of a friend... [emphasis mine]."202 Calle's account reads: "At 10:40 A.M. I get to la Coupole, 102 boulevard de Montparnasse where I have an appointment with Nathalie M. I do not sit at our usual table, but closer to the window, and order a café crème [emphasis mine]." ${ }^{203}$ The different addresses and the different flowers are seemingly insignificant, yet they are details that push us to questions the "truth" of the events described, as both reports reveal different activities. The inclusion of both accounts works to destabilize and contradict the seeming objectivity and authority of the detective's report and underlines the continued undecideability of Calle's accounts.

\footnotetext{
${ }^{200}$ Ibid., 124.

201 Ibid., 128.

202 lbid., 129-131.

203 Ibid., 124.
} 
Most noticeable in the two accounts are the different endings. In Calle's narration of events, the end of the day finishes with a party, dinner, and a late night cab ride:

Half an hour later, at 6 P.M., I leave the theatre. I walk toward Châtelet. At 7 P.M. I arrive at Galerie Chantal Crousel... At 2 A.M. a taxi takes us both [Calle and a friend] to the OK bar at Vavin. I eat spaghetti and drink whisky. At 5 A.M. we grab another taxi to go to his hotel, the Hôtel Tiquetonne. I am drunk and fall asleep. Before closing my eyes, I think of "him." I wonder if he liked me, if he will think of me tomorrow. ${ }^{204}$

But the Detective's Report reads:

At 7:25 the subject leaves the cinema and goes into the Franklin-Roosevelt metro station where she boards a train bound for Pont-de-Sèvres. She changes at Trocadéro and takes the direction Nation. At 7:55 the subject gets off the train at the station Denfert-Rochereau. At 8:00 the subject returns home. The surveillance ends. ${ }^{205}$

The Detective also contains a third section: a report and photographs from Calle's friend François M. Calle writes: "I wanted to have a souvenir of the person who would be following me. I didn't know which day of the week the tailing would take place, so I asked François $\mathrm{M}$ to be outside the Palais de Découverte everyday at 5.P.M. and to photograph anyone who seems to be tailing me." ${ }^{206}$ Stating that she does not know which day the detective will be following her is in direct conflict with the beginning of the project: "I am getting ready to go outside. Outside in the street, a man is waiting for me. He is a private detective. He is paid to follow me. I hired him to follow me, but he does

\footnotetext{
204 Ibid., 126.

205 Ibid., 137.

206 Ibid., 138.
} 
not know." ${ }^{207}$ Or perhaps this merely accentuates the way Calle's projects play with time, as she moves between past and present in her texts, often writing about the events after they have come to pass. The addition of the third account accents the undecideability of the events described.

The detective's account of Calle's day ends with her going into the cinema, then taking the subway home; Calle's account states that she went to a party and then to a hotel, while François M's account offers yet another version of the events. His account ends with these notes: "At 5:25 Sophie Calle entered the Gaumont-Coliseée cinema. The man waited for a few moments; I think he was noting the times of the showings. Then he continued on his way up the avenue to the Lord Byron, where the poster had Emmanuelle and the Daughters of Madam D. At 5:30 the man went into the cinema and that was the last I saw of him."208

The photographs that accompany François M's account, arranged in a group of two and a group of four, show a man in a leather jacket carrying a number of cameras and a camera bag, on a street, crossing a street, and then walking in front of the Cinema Lord Byron (figure 26). Like the shots of Calle, the distance between the photographer and the detective is maintained.

\footnotetext{
207 Ibid., 124.

208 Ibid., 138.
} 


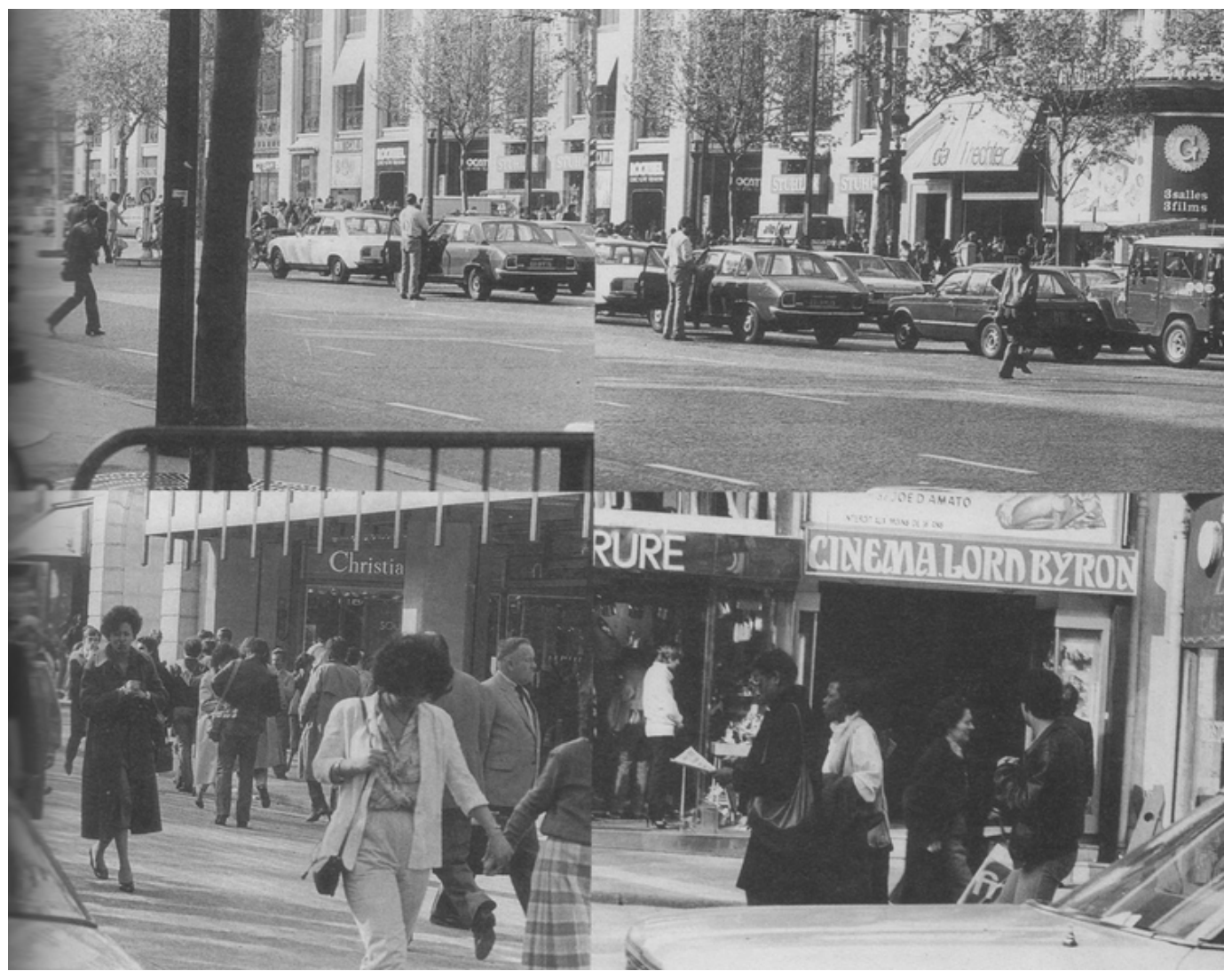

Figure 26. Calle (François M), The Detective, Double Game, 139.

The different endings offered by all three versions enable the event to remain ambiguous and open, by emphasizing the space between what may have happened and what is said, or shown, to have happened. Even though François $\mathrm{M}$ states that entering the cinema was the last that he saw of this man, it does not mean that the detective does not come out of the cinema before Calle's film finishes, to end his surveillance of his subject. We have no way of knowing the ending to this story. As reader/viewer we are left suspended, unable to untangle the events described from those that may have taken place. The Detective makes apparent what Gade and Jerslev describe as performative realism: "an illusion of referentiality, in which it is impossible to decide whether 
we are witnessing something real or fictitious." ${ }^{209}$ As reader/viewer, we have no way of knowing if any of these tales are true. The intrigue in this detective story is that we can never know.

In Leviathan, Auster concludes Maria's version of this project by writing: "When he [the detective] handed in his report at the end of the week and she [Maria] studied the photographs of herself and read the exhaustive chronologies of her movements [in Auster's version the detective follows Maria for "several days"], she felt as if she had become a stranger, as if she had turned into an imaginary being." ${ }^{210}$ In Auster's version Maria fails to recognize herself in the photographs. Auster highlights the gap between what Maria experienced and what was reproduced on film, a space that is accentuated in Double Game through the three differing accounts of the activities of the day.

\section{Conclusion}

By aligning Calle's autofictional projects with performance, I suggest that the event, the autofictional subject, and their representation are always uncertain and in turn speak to the impossibility of full retrieval, something I take up in my next chapter which focuses on archival absence.

The unreliable status of Calle's photographs in both Suite vénitienne and The Detective help draw attention to the contingency of her documents. Through a discussion of Buskirk's and Gratton's essays about Calle's photographs, I attempt to move beyond the binary of documentary and illustration by employing Auslander's concept of the performativity of

\footnotetext{
${ }^{209}$ Gade and Jerslev, "Introduction," 11.

${ }^{210}$ Auster, Leviathan, 63, reprinted in Calle, Double Game, 123.
} 
performance documentation. I also draw on Gade and Jerslev's concept of performative realism as a mode that is always marked by inscription, reiteration and repetition—as difference-as a way to undo the binaries of real and fictional.

Shirley Jordan has written that Calle's work not only "resonates with debates about written or intermedial autofiction," but also engages in current debates about photography by underscoring photography's engagement with "both indexicality and invention." 211 This play with the rhetoric of the photograph opens up the reading of the photograph to new ways of making meaning which, according to Jordan, is "precisely because of its indeterminacy (it is a fictional construct yet in a medium which still remains associated with fact)."

\footnotetext{
${ }^{211}$ Shirley Jordan, "Performance in Sophie Calle's Prenez soin de vous," French Cultural Studies 2, no. 4 (March 2013): 250.

${ }^{212}$ Ibid.
} 


\section{CHAPTER THREE: LIKE IN AN ARCHIVE (The Birthday Ceremony, Days Under the Sign of B, C, and W, The Hotel and The Address Book)}

Nothing seems easier than to draw up a list, in actual fact it's far more complicated than it appears; you always forget something... ${ }^{213}$

\section{The Birthday Ceremony}

On my birthday I always worry that people will forget me. In 1980 , to relieve myself of this anxiety, I decided that every year, if possible, on October 9 , I would invite to dinner the exact number of people corresponding to my age, including one stranger chosen by one of my guests. I did not use the presents received on these occasions. I kept them as tokens of affection. In 1993 at the age of forty, I put an end to this ritual. $^{214}$

This chapter considers the extent to which Calle's projects, The Birthday Ceremony (1980-1993), Days Under the Sign of B, C and W (1999), The Hotel (1981), and The Address Book (1983) exploit the hermeneutics of the archive as a collection of documents and/or objects that act as a record of a past event, a person, or an experience. However, I suggest that Calle challenges her own archival desire and the authority of the archive by accentuating the absences and the fictional in her archival traces. Writing about Calle's work, Yve-Alain Bois asks: "what of all the moments in time that are not inventoried?"215

The Birthday Ceremony consists of fourteen lists, a list of all the presents given to Calle in a particular year (figure 27). In Double Game, each textual list is accompanied by a photograph of the objects described arranged in a glass display case. Described as a "sculptural installation," the lists, when exhibited in

\footnotetext{
${ }^{213}$ Georges Perec, "The Objects that are on my Work Table," Species of Spaces and Other Pieces (London, New York, Toronto: Penguin Classics, 1997 (1976)), 146.

${ }^{214}$ Sophie Calle, The Birthday Ceremony, Double Game, 96-97.

${ }^{215}$ Bois, "Paper Tigress," 35.
} 
a gallery, are etched onto the glass of the display cases and accompanied by the actual objects arranged in the cases, rather than photographs. ${ }^{216}$ The naming and listing of the objects provides a way of accounting for the presents received each year, in no particular order. Much of Calle's work is based on collecting, gathering, and producing information and her work plays with how that information is recorded and represented.

1984

\begin{tabular}{|c|c|}
\hline - Promissory note for a trip to the & 60 etchings: Histoire de Maliette ou les \\
\hline mountains (in Valloire) & peospirités du vise (publisher not \\
\hline - Drwwing by Martial Raysse, signed & given: printed in Switserland) \\
\hline on the back, in a pearl beaded frame & - Booki Le toour du monde en 80 \\
\hline - Book by Marguerite Duras: & plats... et 200 recettes succulenes \\
\hline L'Amant (Editions de Minuit) & (Editions Marabout Flash) \\
\hline - Bottle of Roi David champugne & - Hand warmer with a dosen \\
\hline - Bouquet of twenty roses & refill packets \\
\hline - Ex-roes, on a wood panel, dated & - Tule containing ten $15 \mathrm{~mm}$ llares \\
\hline August 13,1811 & - Stuer-plate hammered metal flask \\
\hline - Nilfisk vacuum cleaner & - Metal lask in a leather sheath \\
\hline - Pair of silk panties with the & - Eiffel Towershaped mirror \\
\hline embeoidered inirials SC & - Four boxes each containing fifty \\
\hline $\begin{array}{l}\text { - } 8 \mathrm{~mm} \text { Parad } 117 \text { llate pistol, } \\
\text { wrapped in a dishtowel along with }\end{array}$ & $\begin{array}{l}\text { waterproof matches and one } \\
\text { beass matchbox }\end{array}$ \\
\hline $\begin{array}{l}\text { the instruction manual and a box } \\
\text { of nine crtridess }\end{array}$ & $\begin{array}{l}\text { - Plastic fold-a-cup for camping. } \\
\text { hiking hyrningand fishing }\end{array}$ \\
\hline - Black sylon kimono & - Disposable hand warmer \\
\hline $\begin{array}{l}\text { - Blue plastic drying rack with } \\
\text { cloebespess }\end{array}$ & $\begin{array}{l}\text { - Image of St Theresa of Lisieux in } \\
\text { a frame inlaid with oyser-shells, a }\end{array}$ \\
\hline - Thirteen pracock feachets & St Theresa of Lisieux candle, a St \\
\hline $\begin{array}{l}\text { - Menu from Le Malakotf, } 6 \text { place } \\
\text { du Trocadera, Paris, } 16 \text { eme }\end{array}$ & $\begin{array}{l}\text { Theresa of Lisieux lighter } \\
\text { - Box containing thirty-one Eiffel }\end{array}$ \\
\hline - Sarong & Tower keyrings and brooches, \\
\hline - Box of chocolates made by & with an instruction to distribute \\
\hline Spründi, Zürich & them on the Trans-Siberian railwa \\
\hline - Book by the Marquis de Sade with & - Beacelet of rubber balls \\
\hline
\end{tabular}

Figure 27. Calle, “1984," The Birthday Ceremony, Double Game, 208-209.

\footnotetext{
${ }^{216}$ Francis Morris, The Tate, http://www.tate.org.uk/whats-on/tate-britain/exhibition/art-nowsophie-calle (Accessed May 28, 2014).
} 
According to Robert E. Belknap, a list is the "predominant mode of organizing data." ${ }^{217}$ It is also important to understand that a list for Belknap is broad and can be a catalogue, an inventory, a lexicon, and an itinerary (actions ordered through time). Narrative also fits within this structure as an "elaborate listing of a series of events." ${ }^{218}$ Belknap suggests that a list is "generative," with the possibility to "spark endless connections and inclusions in a multiplicity of forms." ${ }^{219}$ This is important for Calle's work, which I propose engages the "generative" quality of the list in many of her projects.

William Gass has identified three basic families into which lists can be categorized: 1) "without formalizing principles—random items are placed together in a list" 2) "arranged by a particular principle: alphabetically, numerically, hierarchically, geographically, chronologically and so on," and finally 3) "lists that are built through an externally imposed system, as the structure of a table of contents of a book for example, is dictated by the sequence of the book's parts."220 Double Game's structure can thus be read as a form of the list and Calle's projects exploit all three categories of list making: in The Hotel, Calle photographs individuals' personal belongings that she encounters as she cleans their rooms; in The Address Book, she gathers information from each entry in an address book to construct a portrait of the

\footnotetext{
${ }^{217}$ Robert E. Belknap, "The Literary List," The List: The Uses and Pleasures of Cataloguing (New Haven: Yale University Press, 2004), 8.

218 Ibid., 2-3.

219 lbid.

${ }^{220}$ William Gass quoted in Belknap, "The Literary List," The List: The Uses and Pleasures of Cataloguing, 6-7. William Gass, "And," Habitations of the Word: Essays (Ithaca, New York: Cornell University Press, 1997 (1985)), 117.
} 
man who owned the lost address book; Days Under the Sign of $B, C$ and $W$ plays with the dictionary; The Chromatic Diet organizes food according to the days of the week and colour; and in The Wardrobe, a piece of clothing is mailed yearly to a man whom Calle noticed was "attractive," "but wearing an ugly tie."221 The list offers an alternative way to present an inventory, to identify, to classify, and, important to Calle's work, to structure narrative. The list, as I will elaborate, also parallels the structure of the archive. ${ }^{222}$

In The Birthday Ceremony, Calle's collection of objects can be organized, categorized, and classified in a number of different ways. For example:

- everyday items: washing machine (1991), fridge/freezer (1990)

- luxury items: wine (1990), champagne $(1981,1991)$, perfume (1985), pearls (1993), chocolates (1980)

- clothes and shoes, some worn for a noted number of times: boots (worn 72 times) (1985), shoes (worn 52 times) (1991)

- art work from notable artists, such as: Martial Rayesse (1984), Lawrence Weiner (1986), Jean-Michel Othoniel (1989, 1993), Annette Messager (1985, 1989, 1990), Christian Boltanski (1990, 1993), Cindy Sherman (1993), Jon Kessler (1993), Yves Klein (1993)

- books: (1981, 1983, 1984, 1985, 1986)

- food and drink, some eaten/drunk: chocolates (1990), crayfish fricassee (1992), wine (1983)

- promises made and never honoured: two unknown (1990), Greg Shephard (1992).

${ }^{221}$ Sophie Calle, The Wardrobe, Double Game, 34-35.

222 The relationship of a collection, as a uniting of objects, has much in common with both the book and the archive. In the words of Anne Moeglin-Delcroix, "Le livre, en general a plus d'une affinite avec la collection [The book, in general, has much in common with the collection]." The book (and in our case the display case) thus becomes a way to present the inventory. MoeglinDelcroix argues that the structure of a book is like the structure (and display) of a collection. It must be more than a "recueil d'informations, ou une compilation de documents [collection of information or a compilation of documents]." Anne Moeglin-Delcroix, Ésthetique du livre d'artiste 1960/1980 (Paris: Éditions Jean-Michel Place, Bibliothèque nationale de France, 1997), 185. 
There are even collections within collections: twenty-eight lollipops, twenty-eight earrings, twenty-eight drawing pads (1991); thirty-one Eiffel Tower key rings and brooches (with instructions to distribute) (1984); forty candles (1993). We could easily group together all the objects made of the same material, or according to their size, or price, or according to the date they were manufactured (as a kind of history of the object), or according to the names of the people who offered them as a gift. The possibilities for organization and classification and, by extension, meaning making, are numerous and speak to Belknap's observation that a list is generative, offering multiple connections.

What might at first seem like an incongruous list and collection of objects, "A Walt Disney Productions paper table cloth, four velvet-covered cardboard horses with moveable heads, a gold plastic belt..." 223 are fittingly housed together because of Calle's règles de jeu. It is the yearly ritual played out according to the rules of the game that dictate what objects are to be listed in the text as well as the what objects are to be put on display. We are thus presented with a linguistic and visual inventory as a record and trace of the yearly event. Sophie Calle's birthday ritual, frame and authorize these objects to be together in the list, in the cabinet, and in the photograph.

In his book/catalogue, The Infinity of Lists, Umberto Eco divides the lists into only two categories: the practical list and the poetic list. For Eco, practical lists have three main characteristics: they are referential, they act as a record of things known, and they may not be altered, "in the sense that it would be unethical as well as pointless to include in a museum catalogue a painting that

${ }^{223}$ Calle, The Birthday Ceremony, 200. 
is not kept there." ${ }^{224}$ Calle's birthday lists are an example of the practical list and "represent a form because they confer unity to a set of objects that, no matter how dissimilar among themselves, comply with a contextual pressure, in other words they are related for their being (or for being expected to be found) all in the same place or to constitute the goal of a certain project.".225 As a record, the list refers to the object and the object to its being named on the list. The objects gathered and the collection on display seen in the photographs, seemingly reinforce each other.

The lists and the cabinets are arranged in Double Game according to their date, starting with the first ceremony in 1980 and continuing until 1993 when Calle "decided to bring this ritual to an end."226 The Birthday Ceremony's display of objects mimics curatorial practices and archiving techniques of ethnographic museums: a glass case displays a collection of objects with an accompanying "label" which describes the objects on view.

What is missing from Calle's accounts, however, as in The Chromatic Diet, is the "ceremony" itself — the event remains absent. The yearly birthday ritual is only known through the list and the objects displayed as traces of the ceremony. The photographs that bookend Calle's project, two birds'-eye-views of a table, emphasize the absence of the event. The first photograph is of the table set before a meal with what appears to be forty chairs surrounding the table, and the second photograph shows the remnants of a meal (used plates, ashtrays, chairs scattered around the table). The absence of the event is made

\footnotetext{
${ }^{224}$ Umberto Eco, The Infinity of Lists, trans. Alistair McEwen (New York: Rizzoli, 2009), 113.

225 Ibid., 113-116.

${ }^{226}$ Calle, The Birthday Ceremony, 228.
} 
more obvious through these two photographs which accentuate the before and after of the yearly ceremony (figure 28 , figure 29 ).

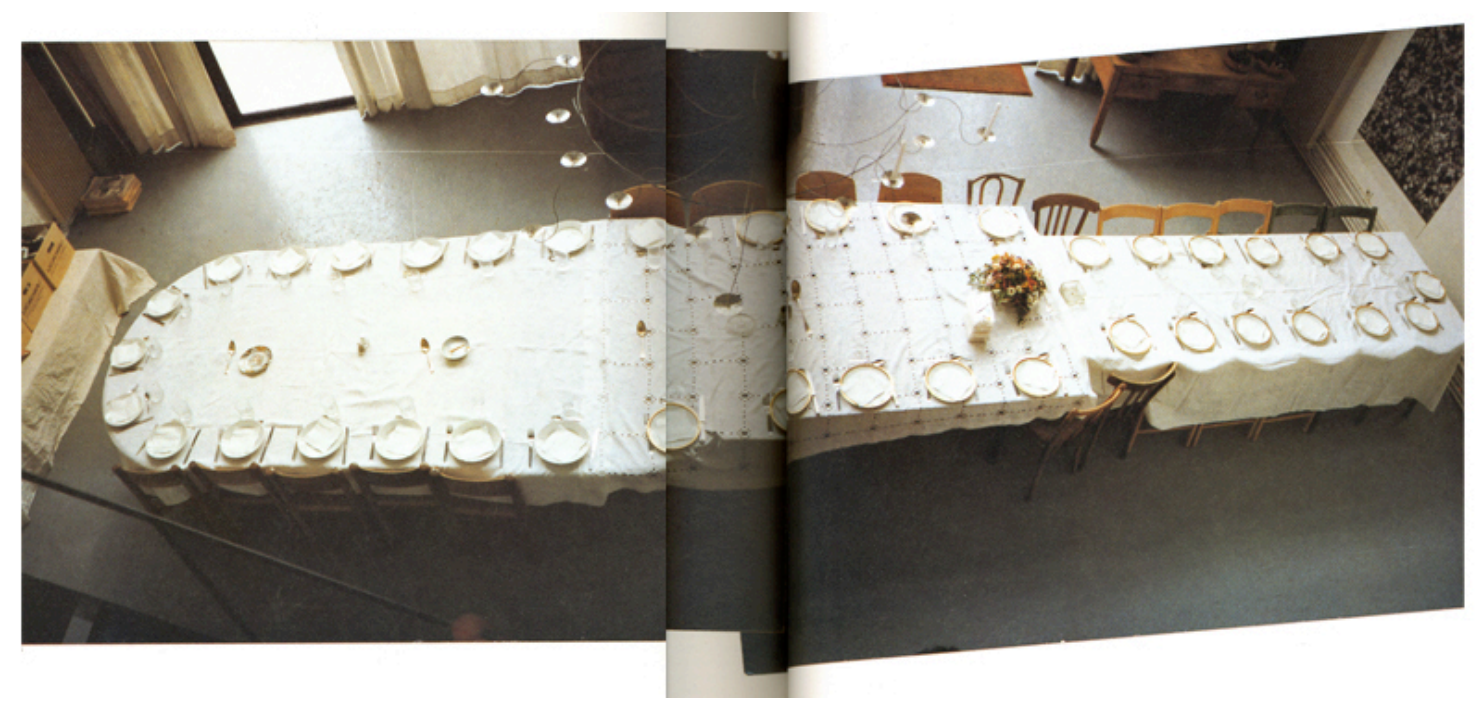

Figure 28. Calle, The Birthday Ceremony, Double Game, 198-199.

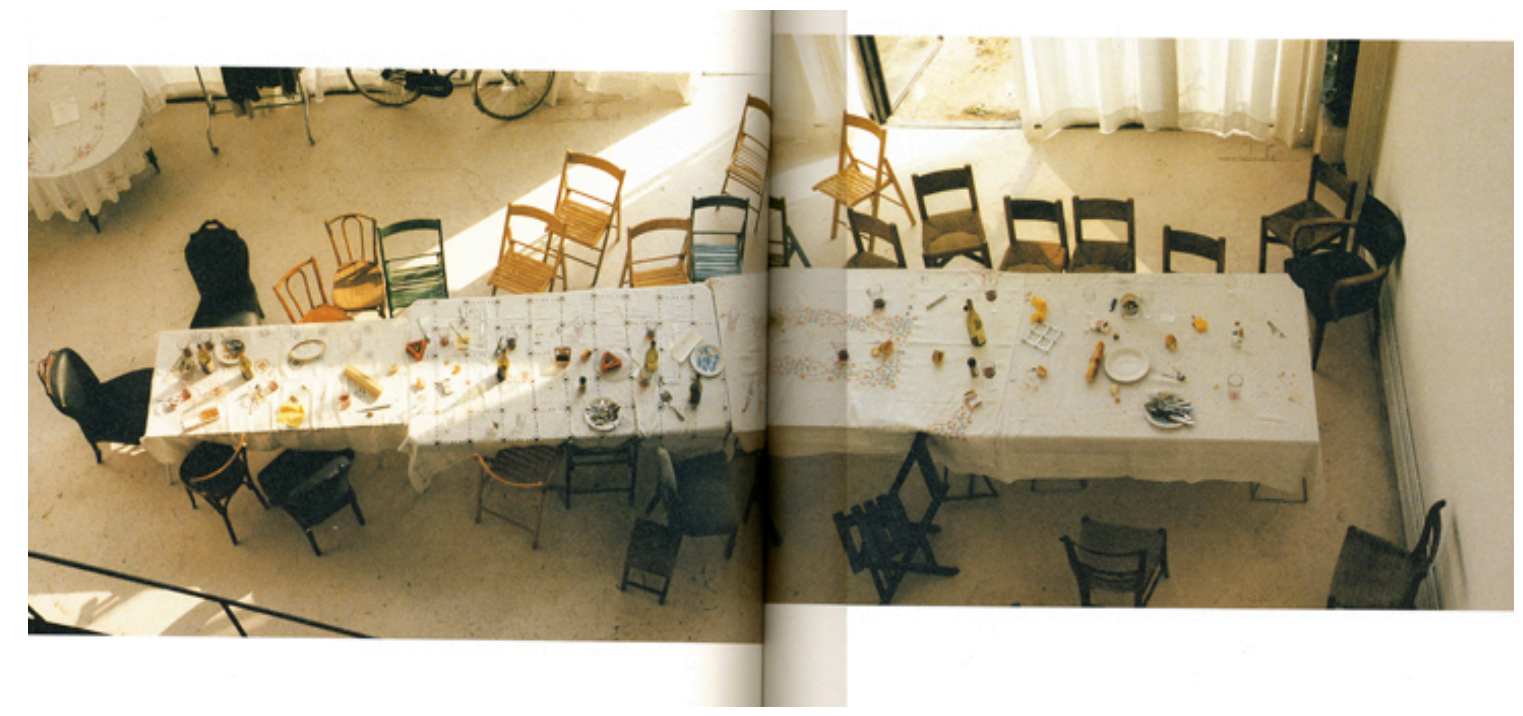

Figure 29. Calle, The Birthday Ceremony, Double Game, 230-231. 
This absence, along with the absence of certain objects in Calle's collection, speaks to archival absences in general. In The Birthday Ceremony, there are a number of items that are literally missing from Calle's archive: "because of its irresistible utility... X is represented by the manufacture's guarantee": the washing machine (1981), the cooker (1982), the radiator (1983), the washing machine [again] (1991), and the cooker [again](1992). There are a number of items "used temporarily": a VCR (1987); the television (1988); and a boxed set of records (1985). The missing items speak to the usefulness of the objects received by drawing attention to the everydayness of certain objects held in this collection.

Also noted in Calle's texts are a number of instances when the ritual is not fulfilled, or when Calle deviates from her own rules, which she includes under the heading "Remarks." For example, about the first year, she writes: "1980: Remarks: Only one of the twenty-seven guests did not turn up. Not counting joint presents, two people came empty-handed. The stranger brought flowers. Pique getting the better of professional conscience, I tore up the telegram." 227 And for 1982, she writes: "Remarks: First break in the ritual. I was away so it was impossible to organize a birthday meal in accordance with the rules of the game. My father gave me the painting. My mother the cooker. Because of its irresistible utility, the latter is represented by the manufacturer's guarantee."228

${ }^{227}$ Calle, The Birthday Ceremony, 200. Calle is referring to a telegram from Jean-Marc Bustamente, the photographer who took her photo when she was dressed up as Brigitte Bardot in Days Under the Sign of B, C and W and also for the cover of Double Game.

${ }^{228}$ Ibid., 204. 
The lists in The Birthday Ceremony act as trace and remnant of a past event and mimic the operations of the archive. The objects and the list, as reference and record, stand in for and mediate lived experience. As literary critic Marco Codebò argues: "The archive's ability to mediate our approach to reality means (1) that the events of our lived experience become intelligible when they are recorded and (2) that records keep their value as proof of lived life only if they are stored in compliance with protocols tested through the historical practice of the archive."229 Calle's use of archival practices along with her autofictional accounts seem to test the boundaries of how objects and documents might mediate and stand in for lived experience.

Like Calle's use of photographs as indicators of "what has been," this collection of objects appears to stand in for the experience and ritual of the yearly birthday ceremony. The objects arranged in the cabinets might also be read as conforming to what art historian Jennifer Gonzalez terms autotopographies, personal objects arranged like a physical map of memory and of history, and understood as a spatial representation of identity: "a museum of the self." According to Gonzales, the objects arranged in autotopography effectively create a space for the memory they seem to represent: "The past is reconstructed in the present to convince ourselves of something we wish to be or have been." ${ }^{230}$ Gonzalez, like Codebò, highlights the object as a means of mediating the past.

\footnotetext{
${ }^{229}$ Marco Codebò, Narrating from the Archive: Novels, Records and Bureaucrats in the Modern Age (Cranbury, New Jersey: Rosemont Publishing, 2010), 13.

${ }^{230}$ Jennifer Gonzalez, "Autotopographies," Prosthetic Territories: Politics and Hypertechnologies, eds. Gabriel Brahm and Mark Driscoll (Boulder, Colorado: Westview Press,
} 
Like all archival traces, these objects sit somewhere between absence and presence. ${ }^{231}$ As trace, these objects no longer refer to a past presence, but rather to an always already absence. For Jacques Derrida, the trace, like the supplement, is neither presence nor absence, but rather another concept that threatens origin. ${ }^{232}$ The impossibility of return and origin is something I stress in Chapter One and in this chapter I want to stress the importance of absence in Calle's use of archival practices. I do not wish to argue for the archive as memory in which some things are remembered/recovered while others are forgotten/buried, but rather focus on Calle's play with absence as a way to mark the impossibility of completeness, of "totalization, fulfillment, [and] plentitude."233

In his book, Narrating from the Archive: Novels, Records, and Bureaucrats in the Modern Age, Codebò identifies what he terms the archival novel: "While functioning in a fictional mode, archival novels perform the same kind of meaning-making operations executed by records, files, and inventories that characterize bureaucratic archives' practices."234 However, Codebò also highlights the tensions "between the storing of records and the plot, or between

1995), 135.

${ }^{231}$ Many of Calle's other projects deal directly with memory as a play between remembering and forgetting. For example, in Last Seen (1991), as in Ghosts, Calle asked curators, guards, conservators, and other staff members at the Isabella Gardener Museum in Boston what they remembered about the thirteen works that were recently stolen (including a Vermeer, and two Rembrandts). In The Bronx (1980), Calle approached strangers in the Bronx and asked them to take her to a place that, should they be able to leave the South Bronx, they would want to remember, which she then photographed and exhibited along with their descriptions. And in Doleur exquise (1984-2003) she repeats the details of a break up daily for three months until the details disappear... marking the act of forgetting over time.

${ }^{232}$ See Jacques Derrida Of Grammatology, trans. by Alan Bass (Baltimore, Maryland: Johns Hopkins University Press, 1974); and Writing and Difference trans. Alan Bass (Chicago: University of Chicago Press, 1978.

${ }^{233}$ Jacques Derrida, "Afterword: Towards an Ethic of Discussion," in Limited Inc., trans. Samuel Weber (Evanston, Illinois: Northwestern University Press, 1988 (1977)), 116.

${ }^{234}$ Codebò, Narrating from the Archive: Novels, Records and Bureaucrats in the Modern Age, 14. 
the archival and narrative dimensions of the text." ${ }^{\text {"235 }} \mathrm{He}$ writes: "An archival novel weaves this dual process of record creation and verification into the fabric of its text, thus functioning as a record all the while narrating the unfolding of its own archivization." ${ }^{236}$ The various projects contained within Double Game also play with this tension, between the creation and storing of physical records (documents, objects, photographs) and the textual narrative, with each unfolding together. Calle thus becomes the archival authority who structures the reader/viewer's experience of the archival traces that she not only constructs, but also narrates. ${ }^{237}$

In Codebò's conception of the archival novel he suggests that the author demonstrates an "awareness of operating at the junction between the discourse of the novel [or in our case, more broadly, fiction] and that of the archive."238 । contend that this parallels autofiction's self-conscious play between verifiable events in the author's life organized and narrated through a fictional framework.

It is not only Calle's individual projects that engage archival hermeneutics, but I argue that Double Game becomes its own archive, existing as a repository for Calle's autofictional documents and traces and is also organized as an "elaborate listing of a series of events." ${ }^{239}$ However, the individual projects play with the operations of the archive by calling into question their own authority through Calle's use of autofiction. Autofiction is thus the critical tool that helps me theorize Calle's archival play as I examine

\footnotetext{
235 Ibid., 13.

${ }^{236}$ Ibid., 25.

${ }^{237}$ Ibid., 14-15.

238 Ibid., 18.

239 Belknap, "The Literary List," 2-3.
} 
the spaces and gaps between what is enacted, what is documented and, finally, how it is classified, organized, and given meaning. The persistence of undecideability, of gaps, and omissions reiterate the inability of the archive to hold the totality of her experiences, to confirm their "having happened."

Calle's work, more broadly, can also be considered an archive, as Calle continually (re)appropriates her own texts and images, recycles stories, mingling each anew with invention, and continually shifts the structure and content of each project, exhibit, and book. As Carolyn Steedman, who writes against the archive as memory, points out:

An Archive may indeed take in stuff, heterogeneous, undifferentiated stuff... texts, documents, data... and order them by the principles of unification and classification. This stuff, reordered, remade, then emerges-some would say like a memory-when someone needs to find it, or just simply needs it, for new and current purposes.

But in actual Archives, though the bundles may be mountainous, there isn't in fact, very much there. The Archive is not potentially made up of everything, as is human memory; and it is not the fathomless and timeless place in which nothing goes away, as is the unconscious. The Archive is made from selected and consciously chosen documentation from the past.... 240

Calle is always drawing on her own always already incomplete archive, reinforcing the endless possibilities for creation and meaning making, through citation and repetition. ${ }^{241}$

\footnotetext{
${ }^{240}$ Steedman continues, "There is a common desire-this has been so since at least the end of the last century - to use the Archive as metaphor or analogy, when memory is discussed. But the problem for us, using Derrida discussing Freud in ordering to discuss Archives, is that an Archive is not very much like human memory, and is not at all like the unconscious mind." Carolyn Steedman, "The Space of Memory: In an Archive," History of the Human Sciences 11, 65 (1998), 66-67.

${ }^{241}$ Perhaps the most obvious example is Les histoires vraies which has been arranged and rearranged in numerous forms including multiple book versions, museum exhibits, as well as unusual installations at The Freud Museum (1999), and Chamber 20 at La Mirande Hotel, as
} 


\section{Days Under The Sign of $B, C$ and $W$}

In Codebò's book on archival novels, one of his chapters focuses on the work of the French writer Georges Perec, an important figure when considering the work of Sophie Calle. Perec is known for his blending of identifiable events in his life, memory, and fiction (W: Souvenir d'enfance (1975); his use of lists and indexes ("Je me souviens" (1978) and "Notes Concerning the Objects that are on my Work-table" (1976)); as well as his interest in the everyday. Codebò examines La Vie mode d'emploi to demonstrate how Perec's novel plays with how the archive "malfunctions." ${ }^{242}$ Calle's work does not so much point to the archive's malfunction but rather to the inability of the archive to recover the past, to retrieve full histories and experiences.

Calle's work is often aligned with the OULIPO group (Ouvroir de littérature potentielle). Founded in 1960 by French writers Raymond Queneau and François Le Lionnais, the group was interested in exploring new structures and patterns for writing through the use of constraints to guide their writing. Most famous of the OULIPO writers is perhaps Georges Perec, and his 1969 novel La Disparition, translated as A Void, which was written entirely without the use of the letter E. While the OULIPO's use of constraints to produce their work is what most obviously links them to Calle's projects, there are a number of

part of the Festival D'Avignon (2013). These stories also makes up part of the narrative of Calle and Greg Shephard's Double Blind/No Sex Last Night (1992). There are also a number of projects by other artists that repeat Calle's content-as yet another form of repetition: Vera Greenwood's L'Hôtel SofiCalle (2001/1997-8); Tim Etchells' Forced Entertainment's staging of Exquisite Pain (2005); as well as a French version which debuted in Montreal directed by Brigitte Heantjens (2009). In this paper I discuss Grégoire Bouillier's The Mystery Guest (2006), but there are numerous other projects in which Calle makes an "appearance."

${ }_{242}$ Codebò, "La vie mode d'emploi by Georges Perec: the archive as a game," Narrating from the Archive: Novels, Records and Bureaucrats in the Modern Age, 119-136. 
overlaps with Perec's work specifically. Perec is known for his interest in the everyday, his projects often attempting to note, account for, and classify his surroundings by noting the everydayness of his experiences, such as "Notes Concerning the Objects that are on my Work-table" (1976) and "The Street" (1974) in which he tries to capture his observations about the street (much like Auster's instructions for Calle in Gotham Handbook). Elizabeth Ridge goes so far as to suggest that Perec is "an absent figure" in Calle's work noting among other things, the resemblance of Auster's project title in French, Gotham Handbook: New York: mode d'emploi, and its similarity with Perec's La vie mode d'emploi (1978). ${ }^{243}$ Johnnie Gratton and Michael Sheringham explore this connection by focusing on Calle's use of les règles de jeux as a way to "generate both a course of action and its corresponding documentation." 244

Perec is also known for his interest in "autobiographical excavation and ludic fictionalization." 245 In his book, Everyday Life: Theories and Practices from Surrealism to the Present, Michael Sheringham writes:

The radical reworking of autobiographical practices that placed life-writing at the centre of the cultural field from the late 1970s was part of a major shift where the structuralist displacement of subjectivity was succeeded by a cautious and questioning "return" of the subject. However as Barthes

\footnotetext{
${ }^{243}$ Emily Ridge's arguments seem to be based on thematics, making broad connections between Calle and Perec's work, related to absence and the detective fiction genre. Ridge even suggests that Calle "lives out scenarios that are described by Perec in his novels" yet fails to substantiate this claim. While interesting, her arguments are not particularly convincing, but I believe that there are links between Calle and Perec that could be explored further. Emily Ridge, "'SO': Tracing Georges Perec in the Work of Sophie Calle," Kaleidoscope: The Interdisciplinary Postgraduate Journal of Durham University's Institute of Advanced Studies (August 2010): 19.

244 Michael Sheringham and Johnnie Gratton, "Introduction: Tracking the Art of the Project: History, Theory, Practice," in The Art of the Project: Projects and Experiments in Modern French Culture (Oxford, New York: Berghahan Books, 2005), 20.

${ }^{245}$ Sheringham, "After Perec: Dissemination and Diversification," 346.
} 
insisted, the "subject" that returns had jettisoned much of its former psychological "baggage," and, rather than laying claim to sovereignty, now displayed its multifaceted and dependant character. If Perec's own work was of major importance here (the publication of $W$ ou le souvenir d'enfance and Roland Barthes par Roland Barthes in 1975 made this a turning point in life-writing), it can be argued that a key aspect of his contribution was to show that the recovery of everyday experience could have a stake in the refashioning of autobiography. Thus alongside the invention of new modes of autobiographic récit, and the ludic spirit of autofiction with its blurring of fact and fiction (to both of which Perec is of course germane), there is an important strand of life-writing, often involving the interface between autobiography and biography, and between individual and collective memory, that gives primacy to the relationship between self and other in the context of ordinary and banal experience. ${ }^{246}$

This long quotation highlights the relationship between Perec's writing and Calle's work which is not simply due to their use of constraints-so often reproduced in texts about their work—but rather considers how their work investigates, reproduces, and theorizes autobiographical acts and involves a ludic play between biography and fiction. According to Sheringham, memory surfaces in Perec's work as a "perturbed and perturbing realm of experience," 247 something that has stronger links with Calle's other projects not included in Double Game.

Days Under the Sign of $B, C$ and $W$, the second project contained within Double Game, connects Calle's work to Perec's directly. Here Calle reenacts another of Maria's projects: "To be like Maria, I spent the day of Tuesday, March 10,1998, under the sign of B for Big-Time Blonde Bimbo; Tuesday, February 16,1998 , under the sign of C for Calle \& Calle in the Cemetery; ${ }^{246}$ Ibid.
${ }^{247}$ Ibid. 
Thursday, March 19, 1998, under the sign of C for Confession; and Saturday, March 14, 1998, under the Sign of W for Weekend in Wallonia." ${ }^{248}$

There are four days and only three letters in this project. The last two pages are for W: "W for Weekend in Wollonia": "To be like Maria I choose to combine in one action all the words beginning with the letter $\mathrm{W}$ that I found on page 321 of my Harrap's pocket French-English Dictionary, and I spent Saturday March 14, 1998, under the sign of W for Weekend in Wallonia."249 In keeping with the OULIPO's use of constraints, each day Calle writes a small text that is dictated by the letter of the day. For example on Thursday, March 19, 1998, Calle writes: “...I Confided, the Catholic Confession Calle Could not Convert. Conserving Candour...." ${ }^{250}$ For W, she begins by referencing Perec's novel:

With $W$ ou le souvenir d'enfance by Georges Perec, and a Window seat on the Wagon-lits, this Weekend I Wended my Way in a restaurant Wagon to Walloon Liège. Sipping a Whiskey, I flipped through a volume on the history of the Western by a 20 Watt bulb. Inevitably, during my journey I went to the WC. I had taken my Walkman and, Working overtime, even Wagner's Walkyrie, a computer to surf the World Wide Web, Works on the Photographers Weegee and William Wegman, and Writings by Walt Whitman. ${ }^{251}$

Underneath Calle's text is an image of the dictionary page listing $10 \mathrm{w}$-words:

W, wagon, wallon, walkman, waters, watt, w-c, week-end, western, and whiskey as markers of her commitment to the words on the dictionary page (figure 30 ).

\footnotetext{
${ }^{248}$ Calle, Days Under the Sign of B, C and W, 22-23.

249 Ibid., 30.

250 Ibid., 28.

${ }^{251}$ Calle, Days Under the Sign of B, C and W, 30.
} 
W for Weekend in Wallonia

To be like Maria, I chose to combine in one action all the words beginning with the letter $\mathrm{W}$ that $\mathrm{I}$ found on page 321 of my Harrap's pocket French-English dictionary, and I spent Saturday, March 14, 1998

under the sign of $\mathrm{W}$ for Weekend in Wallonia.
W

ith W ou le souvenir d'enfance by Georges Perec, and a Window seat on the Wagons-lits, this Weekend I Wended my Way in a restaurant Wagon to Walloon Liège. Sipping a Whiskey, I flipped through a volume on the history of the Western by a 20-Watt bulb. Inevitably, during my journey I went to the WC. I had taken my Walkman and, Working overtime, even Wagner's Walkyrie, a computer to surf the World Wide Web, Works on the photographers Weegee and William Wegman, and writings by Walt Whitman.

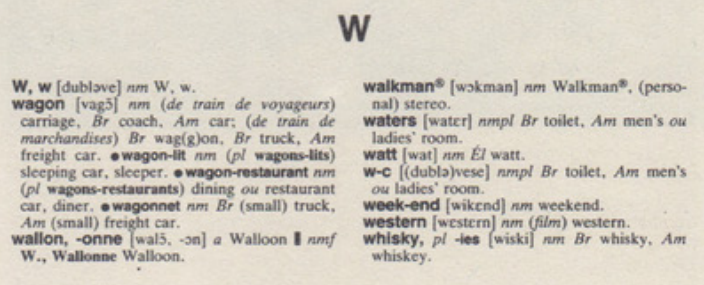

030 DOUBLE GAME

Figure 30. Calle, Days Under the Sign of B, C and W, Double Game, 30. 
The photograph on the adjacent page depicts a table top in a train covered with five books and magazines: $W$ ou le souvenir d'enfance by Georges Perec; Walt Whitman's Comme des Baies de Genevrier; Le Western: approches, mythologies, auteurs, filmographies; a book on the photographs of Weegee; and another on William Wegman. There is also a bottle of Johnny Walker whiskey, a glass which looks like it contains some of this whiskey, a walkman with earphones, a CD for Wagner's Walkyrie, a sign for the WC, a ticket and its cover from the company Carlson Wagonlit Travel (figure 31).

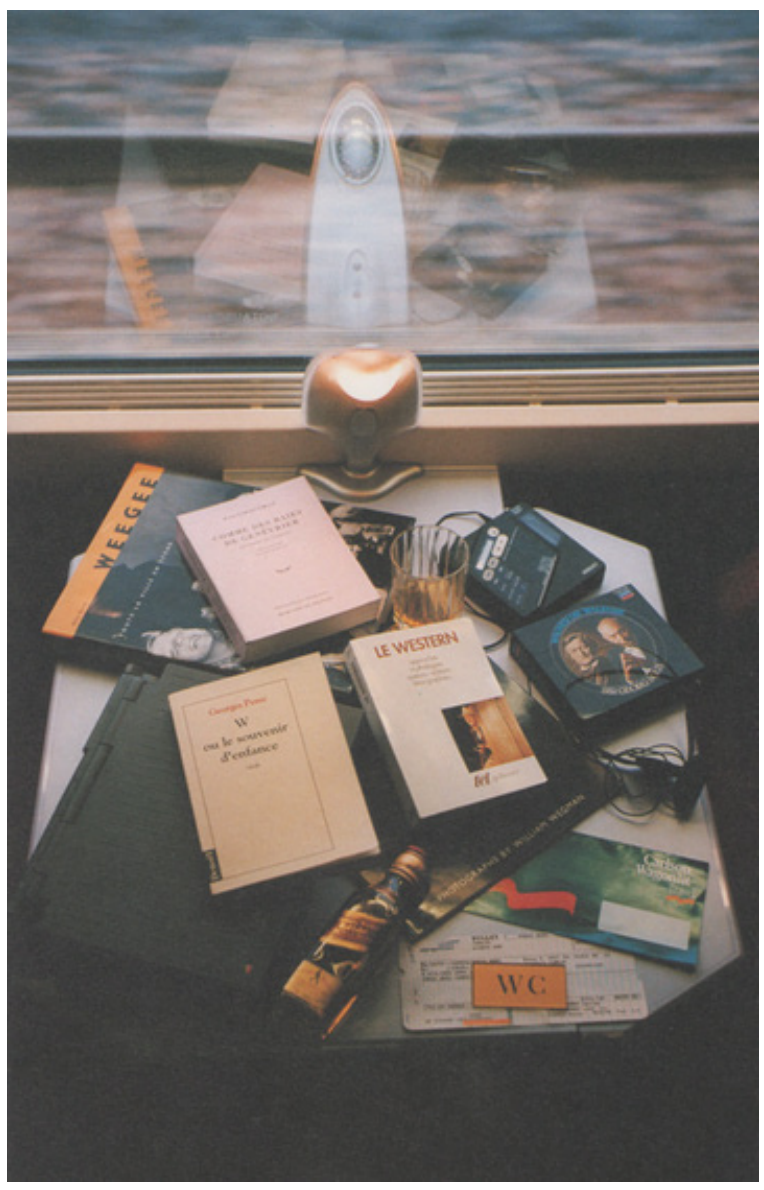

Figure 31. Calle, Days Under the Sign of B, C and W, Double Game, 31. 
Like the photographs and the lists in The Birthday Ceremony, Calle's photographs of the objects in the train, and the photograph of the alphabetic list from the dictionary, as well as her own textual description of the day spent under the sign of $\mathrm{W}$, seemingly reinforce each other and work to convey her commitment to Auster's text.

In his identification of the three basic families into which lists can be categorized, William Gass suggests that alphabetic lists belong to the second family as they are "arranged by a particular principle."252 The dictionary, as a list becomes one of the guiding principles for Calle's project as she replicates the list of words that begin with $\mathrm{W}$. What is not made explicit in the version contained within Double Game, however, is the physical enactment of Auster's projects; again we are left with only the remnants. This absence is made more obvious by looking at the French version of this project, Doubles-jeux, Livre I, De L'obéissance. In the French version there are two photographs that accompany the letter $\mathrm{W}$ : the one that we see here of the objects arranged on the train table, and another image in which we see Calle sitting at the table, the objects in the same arrangement as in our photograph. In this missing photograph Calle is making the sign of $\mathrm{W}$ with her fingers, thus physically enacting the sign with her body (figure 32). The body, seemingly grounding the work as having taken place, is proof and anchor for the event having happened as described. In all three of the other images in this project as presented in Double Game, Calle is in the photograph, making her corporeal absence in "W for Weekend in Wallonia" more noticeable.

${ }^{252}$ William Gass quoted in Belknap, "The Literary List," 6-7. 


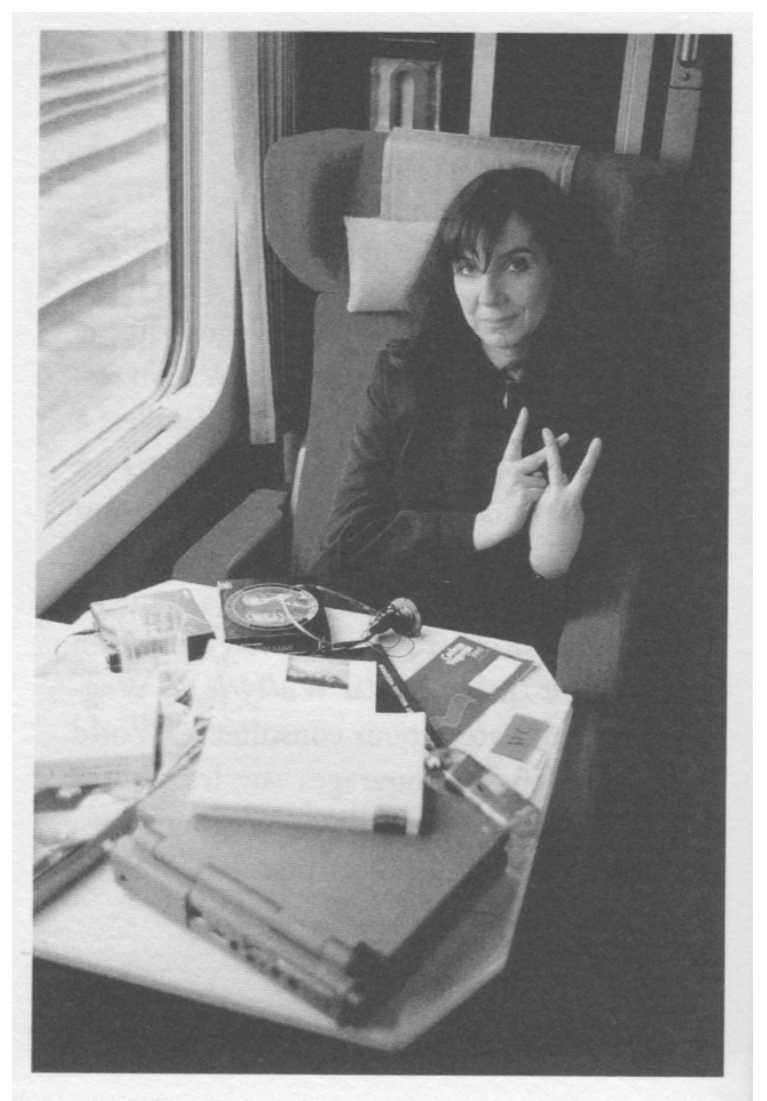

Figure 32. "W comme Weekend en Wallonie. Des journées entières sous le signe du B, du C, du W, De L'Obéissance (Livre I), Doubles-jeux (Arles: Actes Sud, 1998), 60.

\section{Archival Absence}

In his book, The Big Archive, Sven Spieker argues that: "Archives do not record experience so much as its absence; they mark the point where an experience is missing from its proper place, and what is returned to us in an archive may well be something we never possessed in the first place." ${ }^{253}$ The archive's own ambition to archive the totality of the past is understood to be an impossible desire. I return to The Birthday Ceremony, in which I argue, we become more

${ }^{253}$ Spieker, The Big Archive: Art from Bureaucracy, 3. 
aware of this fantasy of plentitude through the archival gaps, the missing objects, and the missing event. Just as the archive's own ambition to archive the totality of the past is understood to be an impossible desire, it has been argued that autobiography also "reveals the impossibility of its own dream: what begins on the presumption of self-knowledge ends in the creation of a fiction that covers over the premise of its own construction." ${ }^{254}$

\section{The Mystery Guest}

Archival absence is emphasized in another account of Calle's birthday ceremony. In his autofictional novella, The Mystery Guest (2006), author Grégoire Bouillier describes being invited, by a friend, on the phone, to Sophie Calle's birthday party in 1990: “...every year this friend had a birthday party and invited as many people as she was years old plus a 'mysterious guest,' who stood for the year she was about to live, and this year she [the friend on the phone] was in charge of bringing the mysterious stranger and she couldn't say no and she'd thought of me...."255

In Bouillier's novella, the central character, Grégoire Bouillier, attends Calle's birthday party. Bouillier spends time describing the details of his gift, an expensive bottle of champagne, a 1964 Château Margaux, grand cru, the price of which is way beyond his means, but something he purchases anyway. Bouillier describes this moment of purchasing the bottle: "I actually pranced with

\footnotetext{
${ }^{254}$ Shari Benstock, "Authoring the Autobiographical," in The Private Self: Theory and Practice of Women's Autobiographical Writings (Chapel Hill: University of North Carolina Press, 1988), 11. ${ }^{255}$ Grégoire Bouillier, The Mystery Guest, trans. Lorin Stein (New York: Farrar, Strauss + Giroux, 2006), 12.
} 
delight in front of the clerk." ${ }^{256} \mathrm{He}$ brings his gift to Calle's party and describes in detail the nonchalant way his ex-wife and Calle handle the bottle, as well as the shock and disappointment he feels when Calle takes the bottle into the kitchen, out of sight, when he wanted instead to see her open his luxurious gift. The moment that Bouillier is told that Calle never opens or uses the presents she receives is one of horror: "At first I refused to believe it... I assumed she [his exwife] was joking just to scare me and rob me of the last shred of my dignity." 257 Bouillier is horrified that the gifts received are immediately sealed away never to be used, enjoyed, or experienced. They find their place in the world only through their participation in Calle's lists, displays and photographs-as archive.

Important in Bouillier's novel is that it begins with the death of Michel Leiris, author of La règle du jeu (1948-1976), an autobiographical exploration of his inventory of memories, broken into four volumes. Like Serge Doubrovsky, and Georges Perec, Michel Leiris is known for his play with autobiography and fiction. At the party, Bouillier is introduced to another important writer of autofiction: Hervé Guibert. Guibert is also an important person in Calle's life/work. Guibert was the first to articulate the force with which Calle spins tales: a "faiseuse d'histoires." ${ }^{258}$ Guibert is also the friend whose ashes Calle empties into the sea in her video Double Blind/No Sex Last Night (1992), and the man with whom she shares her bath water in Doleur exquise (1994-2003).

\footnotetext{
256 Ibid., 35.

${ }^{257}$ Ibid., 59.

${ }^{258}$ Hervé Guibert, "Les tribulations de Sophie Calle en enfance," Le Monde, Arts et Spectacles, jeudi le 16 août, 1984.
} 
These references are, in my opinion, carefully planted in Bouillier's novel as a way to highlight the autofictional and retiterative nature of not only his own work, but also the work of Sophie Calle. At another moment, Bouillier meets a woman who tells him that she steals flowers from Pierre Laval's grave in Montparnasse daily and takes them home. This is a memory that appears elsewhere in Calle's work, attributed to her mother who steals the flowers from Laval's tomb to put on Baudelaire's grave. These are all people important to Calle and, like Auster, it feels as though Bouillier is weaving elements from Calle's life/art, borrowing from her autofictional archive, and "mingling" them in his own autofictional account of the evening. This intertextuality, like Auster and Calle's "mingling of fact and fiction," can be read as another strategy for emphasizing that texts always carry the trace of other texts, in Barthes words: "The text is a tissue of quotations drawn from the innumerable centres of culture. ${ }^{259}$ Bouillier leaves the party dejected and upset at the thought of his present never being enjoyed.

The last section of his novella takes place fifteen years later. Calle approaches him at another party to congratulate him on the publication of his first novel, Rapport sur moi (2002), not realizing that he had been one of her mystery guest years before. They chat and a few days after this second encounter, Calle phones Bouillier:

My story about the mystery guest had intrigued her and she'd gone to the book where she kept a record of all the birthday presents she'd received over the years, and she checked to see whether she could find the Margaux, and she hadn't

${ }^{259}$ Barthes, "The Death of the Author,"146. 
found a trace of it, not in the chapter on the year 1990 or anywhere else... she'd gone down to the basement where she stored her work... she spent hours turning the place upside down... and way up high on a shelf she'd found a bottle of wine still wrapped in tissue paper and it was a 1964 Margaux, and it had to be mine, and she'd found it! ? $^{26}$

Calle's finding of the bottle of Margaux, addresses, in many ways, Carolyn Steedman's situating of the archive, written partially in response to Derrida's Archive Fever, in which she talks about the real space of the archive, in this case, Calle's (dusty) basement: "These [the French Archives] are the origins of that prosaic place where the written and fragmentary traces of the past are put in boxes and folders, bound up, stored, catalogued."261 Calle's "real" archive, works as another kind of doubling, another version of her archive displayed and documented in The Birthday Ceremony. ${ }^{262}$

In his book, The Big Archive, Spieker writes about Calle's Appointment (1999), a project in which objects and autofictional narratives from her earlier project, Autobiographical Stories, were installed in and around the Freud Museum in London. Spieker observes that Calle's installation, "her belongings and narratives," actually question the "material and symbolic coherence of Freud's museum and archives...."263 Like the rediscovered bottle of Margaux that asks us to question the archive's completeness and authenticity, Spieker

\footnotetext{
${ }^{260}$ Bouillier, The Mystery Guest, 116-117. Apparently two gift certificates that appeared the next morning were noted in Calle's projects as the gifts from the Mystery Guest.

${ }^{261}$ Steedman, "The Space of Memory: In an Archive," 67.

${ }^{262}$ In his book The Big Archive: Art from Bureaucracy Sven Spieker's elaborates on the importance of the uncanny in the archive. Calle's retrieval of the bottle of wine in her basement could be read as mark of the uncanny: "the return of the familiar, despite if being forgotten from our file registers." Spieker, The Big Archive: Art from Bureaucracy, 3.

${ }^{263}$ Ibid., 186.
} 
argues that Calle's objects installed at the Freud Museum "reopen what appeared to be a complete collection." ${ }^{264}$

Bouillier's (autofictional) novella shows us that Calle's archive is always already incomplete and accentuates this gap between what is known and what is unknowable, what is experienced and what is archived. The event, Calle's party, can never be known through a collection of lists, objects, and photographs. I want to make it clear, however, that I am in no way privileging Bouillier's participation (real and/or fictional) in the event (real and/or fictional) over the documents (real and/or fictional). I am more interested in how the event is reiterated, transformed into a series of possibilities and a series of documents, documents that then participate in new structures of meaning making as part of a network of relational and, often, competing discourses. This rhizomatic structure of Calle's archives is made most obvious in Gotham Handbook, which I discuss in Chapter Five.

If The Birthday Ceremony, and Bouillier's version of Calle's birthday party, emphasize archival absence as it relates to the literal and physical archive, understood as a collection of objects, then Calle's The Hotel demonstrates how Calle's archives also point to the uncertainty of the trace, as a mark, not of lost presence, but rather the impossibility of presence altogether.

\footnotetext{
${ }^{264}$ Spieker, The Big Archive: Art from Bureaucracy 186. Spieker relates Calle's work to Freud's archive, psychoanalysis and its archive. But I would equally argue that she opens her own archive by continually reappropriating her own stories, objects and photographs.
} 


\section{The Hotel}

Calle tells us that in 1981 she worked as a chambermaid in a Venetian hotel: "On Monday, February 16, 1981, I was hired as a temporary chambermaid for three weeks in a Venetian hotel. I was assigned twelve bedrooms on the fourth floor. In the course of my cleaning duties, I examined the personal belongings of the hotel guests and observed through details lives which remained unknown to me. On Friday, March 6, the job came to an end." ${ }^{265}$ In this project Calle takes on the role of a chambermaid/detective and attempts to (re)construct/imagine the lives of the guest from the objects encountered in their rooms. ${ }^{266}$

Reading the objects belonging to the hotel guests as signs and traces of their lives can be read as another example of autotopography. However, Calle's text acknowledges the impossibility of this task: "...lives which remained unknown to me." This inability to know underlines the impossibility of the autotopographical, the autobiographical and the archival to render the totality of experiences and of subjects. As I have articulated throughout my discussion of Calle's Double Game, the autofictional traces constructed (and planted) for our reading and viewing seem to point to the necessity of absence in all work that engages with the politics of the archive.

The Hotel is organized first by room, then by date. The project begins with Room 25, and starts on Monday, February 16, 9am. There are four entries for

\footnotetext{
${ }^{265}$ Sophie Calle, The Hotel, Double Game, 140-141.

${ }^{266}$ This project is a slight deviation from the other projects contained within Double Game for it appears to evolve from her engagement as a chambermaid, rather than her rules dictating that she get a job as a chambermaid to carry out the project.
} 
this room, ending with: "Thursday 19, noon. He is gone. He has left his orange peel in the wastebasket, three fresh eggs on the windowsill and the remains of a croissant which I polish off. I shall miss him." ${ }^{\text {267 }}$ Even in Calle's texts it is the absence of the guests that is highlighted.

Each room is introduced with a colour photograph of a made bed. The colour photograph resembles a photograph you might find in a hotel brochure, and serves to accentuate, and perhaps make more obvious, the use of black and white photography for the images of the belongings and traces of the guests (figure 33).

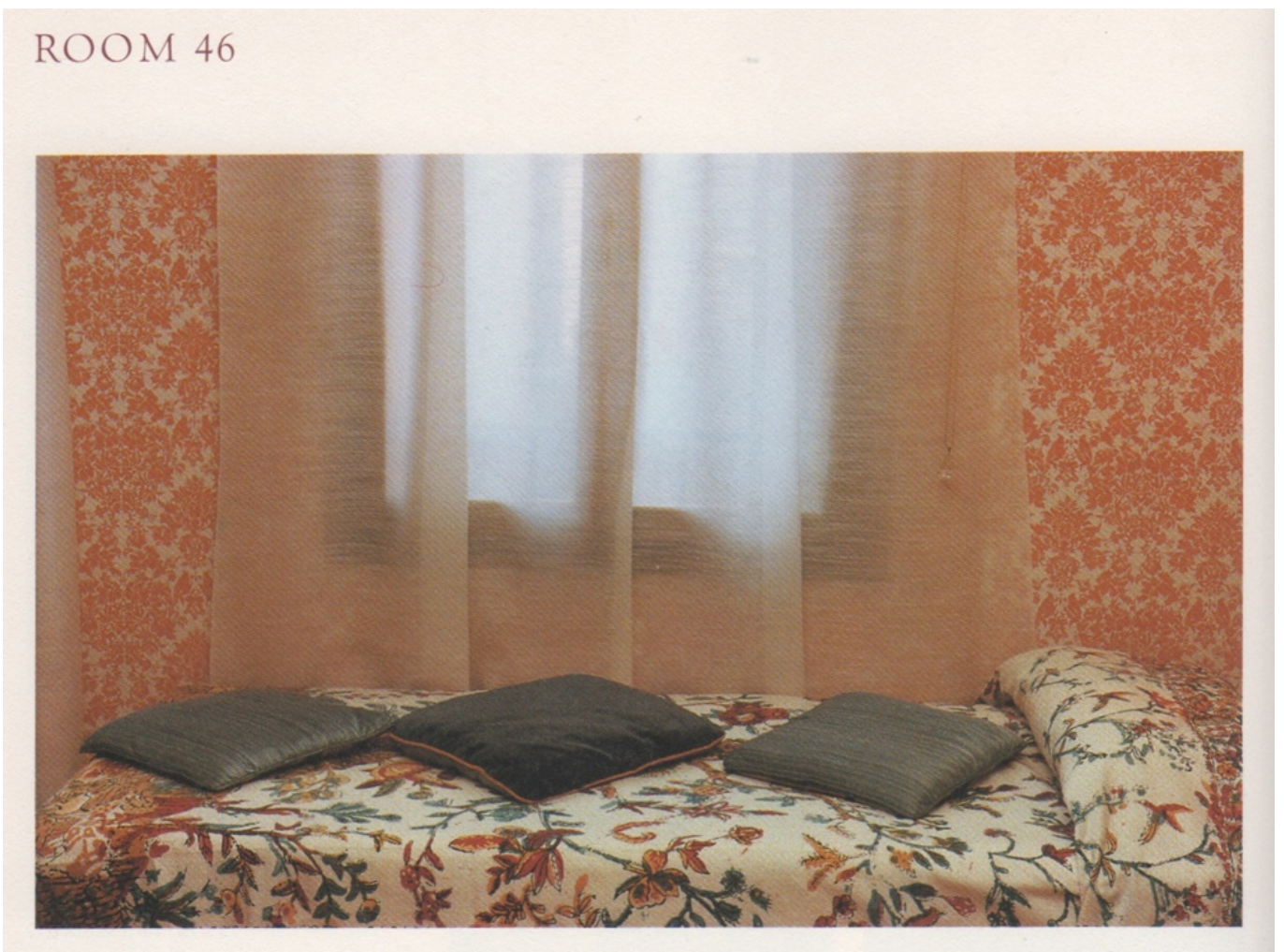

Figure 33. Calle. "Room 46," The Hotel, Double Game, 155.

${ }^{267}$ Calle, The Hotel, 145. 
This project's connection to detection and the detective genre is, in my mind, rather obvious and the photographs reflect this association; the black and white photographs resemble crime scene photographs, banal objects systematically photographed in a rather straightforward manner. ${ }^{268}$ In an attempt to try to understand the photographs, like Calle we begin to read the objects as signs of the missing guests-looking for clues. ${ }^{269}$ The photographs that accompany the various descriptions are of shoes, clothes, dirty laundry, journals and diaries, unmade beds, opened suitcases, bathroom necessities, bedside tables, wastepaper baskets, etc. (figure 34).

\footnotetext{
${ }^{268}$ Henry Bond suggests that Calle photographs the rooms as if they were a crime scene. Henry Bond, "Hard Evidence," Lacan at the Scene (Cambridge, Massachusetts: The MIT Press, 2009), 23. And Michael Sheringham compares them to "scene-of-the-crime shots of a photographer like Weegee." Michael Sheringham, "Checking Out: the Investigation of the Everyday in Sophie Calle's L'Hôtel," Contemporary French and Francophone Studies 10, 4 (December 2006), 417.

${ }^{269}$ In an article on Calle's Suite vénitienne, Whitney Chadwick aligns her project with detective fiction in which the pursuit of the subject, the object of desire, "is similar to the passion that drives the scholar's search through the archives, and the desire to know that motivates the writing (and reading) of crime fiction." Whitney Chadwick, "Three Artists/Three Women: Orlan, Annette Messager and Sophie Calle," Contemporary French and Francophone Studies 4 (2000), 113.
} 


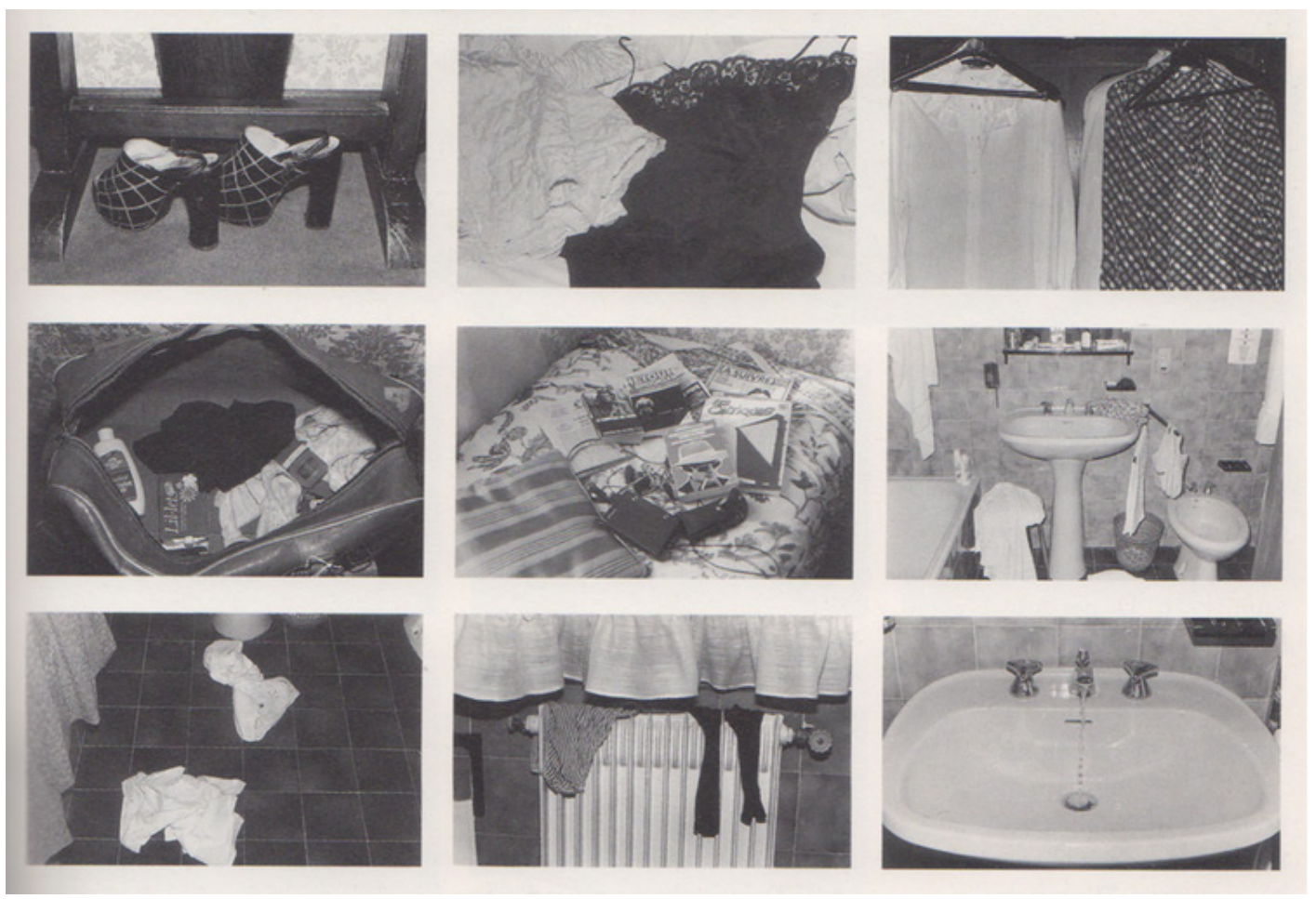

Figure 34. Calle, "Room 46," The Hotel, Double Game, 155.

In Auster's description of this project in Leviathan, he hints at the connection between the objects photographed and a crime scene, and describes the objects in such a way that they hint at some sordid event:

For her next project Maria took a temporary job as a chambermaid in a large mid-town hotel. The point was to gather information about the guests, but not in an intrusive or compromising way. She intentionally avoided them in fact, restricting herself to what could be learned from the objects scattered around their rooms. Again she took photographs; again she invented life stories for them based on the evidence that was available to her. It was an archeology of the present, so to speak, an attempt to reconstitute the essence of something from only the barest fragments: a ticket stub, a torn stocking, a blood stain on the collar of a shirt. ${ }^{270}$

${ }^{270}$ Auster, Leviathan, 63, reprinted in Calle, Double Game, 141. 
As in The Birthday Ceremony, the objects photographed appear to correspond with the textual descriptions. In The Hotel, the text provides not only a practical list of the objects observed, but also a description of Calle's activities, conversations heard, and any contact with the various guests as they come and go:

In the bathroom, men's toiletries and three bathmitts. The man wears Nouvelle Image cologne. I photograph the locked suitcase, the indecipherable postcards [in German], all of these signs in vain. I hear some noise in the stairwell and hide my camera in my pail. The door opens. He comes in. He has a nice smile. In hesitant Italian, I think he says to me, 'Thank you for all of your kindness,' and he hands me some lire. My first tip. I return his smile and leave the room. ${ }^{271}$

Calle's entries for each room note the personal items found in the various rooms, her observations and assumptions about the guests. She also notes any interaction. The list is transformed into a diary as the descriptions offer both objective and subjective comments that describe her experiences. As Suzanne Bunkers and Cynthia A. Huff have argued, the diary has long been established as a primary document for mining information about a writer's life. ${ }^{272}$ Double Game plays with this notion of intimacy and truth associated with the diary from the very beginning by wrapping Double Game with a maroon ribbon which has to be untied to open the book/diary/archive. ${ }^{273}$ On the one hand, the ribbon invokes the tradition of the diary to suggest a certain kind of intimacy, a

\footnotetext{
${ }^{271}$ Calle, The Hotel, 150.

${ }^{272}$ Suzanne L. Bunkers and Cynthia A. Huff, "Issues in Studying Women's Diaries," in Inscribing the Daily: Critical Essays on Women's Diaries (Massachusetts: University of Massachusetts Press, 1996), 1.

${ }^{273}$ To Follow... includes photographs from Calle's "Following" journals and the exhibition catalogue from her retrospective at the Centre Pompidou in 2007 contains a section of photographs of the pages from Calle's dairies. The diary is a form that she returns to in many of her projects.
} 
"revealing" of the inner life of the artist—something not evoked in the collecting of information. ${ }^{274}$ On the other hand, however, the cover photo of Calle masquerading as Brigitte Bardot, in a project created for Maria by Auster, makes literal a series of repetitions and displacements; the "real" identity/life of the author is never "revealed," but always caught up in fictions. What I want to stress, instead, is the way in which, as Bunkers and Huff articulate, the form of the diary is both "elastic and tight, borrows from and at the same time contributes to other narrative structures," and "brings into play issues of historical and social self-construction.,275

Calle's diaristic entries reinforce her movement and play with her roles as detective/criminal and artist/chambermaid: reading the clues, and the absences and constituting the identity of the guests, while she trespasses on their lives, rummaging through drawers, reading their diaries, and recording their personal details with her camera which she hides in her bucket as she cleans. The narrative plays out more like a suspense novel, where the detective gathers her clues only to find that the criminal is the trespassing Calle.

What often surfaces in discussions of this work is a comment made by Calle when she was interviewed by Lawrence Rinder:

...in most of my work there is one lie. For example, in The Hotel series, in which I photographed people's rooms-all the rooms are perfectly right, there is nothing that I add, nothing I lie about. But there is one room that is completely fake. It's a room I would have liked to have liked to find [sic] and didn't. I

\footnotetext{
${ }^{274}$ Michael Sheringham suggests that L'Hôtel is a record of the project in "the form of a diary accompanied by a photographic inventory." Michael Sheringham, "Checking Out: The Investigation of the Everyday in Sophie Calle's L'Hôtel," 417.

${ }^{275}$ Bunkers and Huff, "Issues in Studying Women's Diaries," 1.
} 
put my fantasy inside. In The Blind [not included in Double Game] there is one whose answer I gave myself. ${ }^{276}$

Knowing that one of the rooms is "completely fake" threatens to "infect" the rest of the archive, as we now doubt each description as it is written and shown. Calle's statement is particularly important for it challenges the "truth" of her observations and documentation by questioning the integrity and authenticity of all the photographs and all the descriptions since we will never be able to discern the real room from the fake. I also suggest that Calle's statement reiterates the importance of undecideability, not only here in this project but her broader archival project that is her life/art. As Calle admits, it is not just this project that includes completely constructed "evidence."277

Her acknowledgment of the possible fictionality of her documents in The Hotel, even only one of her documents, works against the perceived "documentary" status of the photographs (aligned with police reports and forensic photographs) by reinforcing that photography does not only record reality but constructs it. The continual tension between what is said and what is seen are, as Geoffrey Batchen has argued, already tensions addressed by the photograph itself: "between activity and passivity, presence and absence, time and space, fixity and transiency, observer and observed, real and

\footnotetext{
${ }^{276}$ Lawrence Rinder, "A Conversation with Sophie Calle," CALENDAR, (Berkeley: University Art Museum, 1990), unpaginated.

${ }^{277}$ There is also mention of one of the cabinets in The Birthday Ceremony being a "fake" but I have only come across this reference once based on an oral account of the exhibition. See Sophia Phoca, "She's Street-wise and a Stalker: Sophie Calle's The Birthday Ceremony," Third Text, 13, no. 45 (Winter 1989-99): 103.
} 
representation, original and imitation, identity and difference-and the list could go on." ${ }^{278}$

I stress the insistence of the play between presence and absence in Calle's work. In Double Game, absence, particularly the absence that haunts the archive, is a crucial component of these projects; there are missing events, missing objects, missing projects, things forgotten, things left out: events and experiences that will always remain unknown. These absences foreground how Calle's autofictional traces supplement (add to, defer and displace) the missing object, events and individuals. In The Hotel, the absence of the hotel guests is made explicit in the photographs: unmade beds still carrying the traces of the sleepers; shoes and clothes discarded on the floor; and the empty space of the hotel room (figure 35, figure 36). Calle's diaristic descriptions also expose the interplay between absence and presence and emphasize Calle's inability to reconstruct past events and identities for the guests:

Room 28: Friday 6, 10am. ... I leave it up to my successor to observe the variations on the pillows in Room 28. Today, the one on the left, falling off the bed slightly, bears the rounded imprints of a presence. I see this as a farewell sign. Room 16: He has left without revealing himself. ${ }^{279}$

What is thus highlighted is Calle's (and our) inability to know... the guests and the event. Instead, what surfaces is a work that documents and archives the objects and traces of the individual hotel guests, a project that seems to reinforces the contingency of the trace.

\footnotetext{
${ }^{278}$ Geoffrey Batchen, Burning with Desire: The Conception of Photography (Cambridge, Massachusetts: The MIT Press, 1997), 179.

${ }^{279}$ Calle, The Hotel, 149, 151.
} 

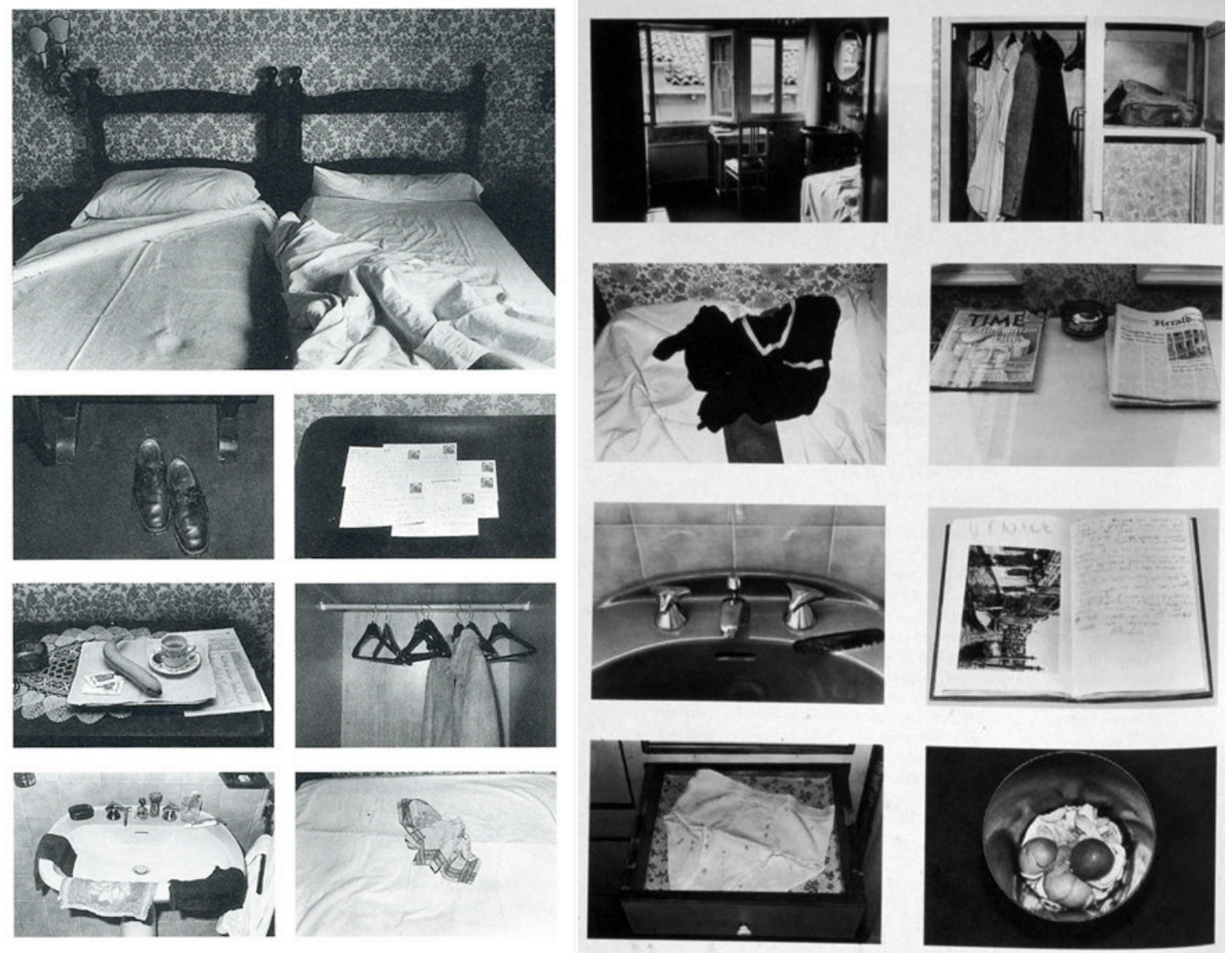

Figure 35. Calle, "Room 44," The Hotel, Double Game, 151.

Figure 36. Calle, "Room 25," The Hotel, Double Game, 145.

\section{Archives and Archeology}

Spieker suggests that Calle (along with other artists such as Michael Fehr, Andrea Fraser, and Susan Hiller) questions "the archive's archeological [emphasis mine] logic by introducing error-false or fantasmatic inscriptions...." 280 Spieker understands that what is at stake is the notion of play, a concept he argues that challenges the nineteenth-century archive with its "objectivist pathos and claim to the 'presence of the past' and the taming of

${ }^{280}$ Spieker, The Big Archive: Art from Bureaucracy, 174. 
contingency." ${ }^{281}$ By introducing false objects and observations into her project, Spieker claims that Calle disrupts the "archeological logic" associated with the archive, a logic that connects objects to reconstruction, to the past, and to origin, challenging the archives "immunity from tampering." 282

Paul Auster makes more obvious this connection between play and invention based on remains: "Again she took photographs; again she invented life stories for them based on the evidence that was available to her. It was an archeology of the present...." ${ }^{283}$ Calle rummages through the objects in the hotel rooms that belong to the guests in an attempt to discover the lives of the hotel guests yet what emerges, instead, is a collection of photographs and diary entries that reiterate her inability to "discover" or reconstruct the past, offering instead only the "barest fragments."

French literary critic Michael Sheringham argues that Calle's project can be situated within a larger turn to an interest in the everyday that can be witnessed in French culture after the death of Perec (1982). Sheringham contends that in The Hotel, Calle's "inventory's gesture towards closure and definitiveness is rendered ironic by its necessary arbitrariness and incompleteness." ${ }^{284}$ For Sheringham what is at stake is not the "individual personality but everyday practice, a level of experience where sameness and difference, repetition and endless variegation stake out the daily territory in

\footnotetext{
${ }^{281}$ Ibid.

282 Ibid., 175.

${ }^{283}$ Auster, Leviathan, 63, reprinted in Calle, Double Game, 141.

${ }^{284}$ Sheringham, "Checking Out: the Investigation of the Everyday in Sophie Calle's L'Hôtel," 423.
} 
which we are all immersed." 285 However, within the context of Double Game, as an autofictional account of Calle's autofictional acts, I suggest that what is continually reiterated is that the subject is always under (de)construction and often represented as an absence.

\section{The Address Book}

If we understand Double Game to be its own (autofictional) archive, then Calle's project The Address Book (1983) speaks most loudly to archival absences because the project is entirely missing from the book. This project reiterates the absent subject in a very literal way:

In the summer of 1983, a French newspaper asked me to write a series of articles. Not long before, I had found an address book. I decided to photocopy the contents before sending it back anonymously to its owner, whose address was given on the endpaper. I then contacted those people whose names were noted down and asked them to tell me about the owner. Thus I would get to know this man through his friends, his acquaintances. I would try to discover who he was without ever meeting him and to produce a portrait of him, over an uncertain length of time, that would depend on the willingness of his friends to talk about him and on the turn taken by events. ${ }^{286}$

There were twenty-eight original publications in the newspaper Libération but due to a later legal agreement between Calle and the owner of the address book, Pierre D., Calle agreed not to republish this project until after his death. Double Game therefore contains only a few remarks about Pierre D., Calle's description of the project, and the legal information, ending with: "This is why, for legal reasons, and because... [Here she quotes all the publisher and

\footnotetext{
${ }^{285}$ Sheringham, "Checking Out: the Investigation of the Everyday in Sophie Calle's L'Hôtel," 423.

${ }^{286}$ Sophie Calle, The Address Book, Double Game, 186-187.
} 
violation of privacy jargon needed] that the full story of The Address Book is missing from this publication." ${ }^{287}$ Like the absence of the event in The Birthday Ceremony, the absence of the objects of study (the guests) in The Hotel, not only is the subject of her investigations absent here, but also the full project is missing from her archive (Double Game). ${ }^{288}$

As in The Birthday Ceremony, The Address Book is framed by two photographs, the first and last image from the newspaper pages. The first is dated "Mardi, 2 août, 1983" and shows a photograph of two statues embracing, one of whose faces has been removed, along with the textual introduction to Calle's project, the last line of which reads: "J'apprendrais à la connaitre, II s'appelle XXXX."289 The last image is a black and white photograph of what looks like a blurred landscape taken from a moving vehicle. It is titled "Dernière journée," and dated "Samedi 3 et dimanche 4 septembre 1983." ${ }^{290}$ Calle writes about wanting to meet him [Pierre D.] in the street, believing she would recognize him, but without stopping to talk. It ends with "Au revoir XXX, Sophie." ${ }^{291}$

The Address Book consists of three main sections. The first section describes the book and lists its contents, according to the alphabetic divisions already marked in an address book: "In this thick, faded hardback notebook with torn red binding and a black spine, measuring fifteen by twelve

\footnotetext{
287 Ibid., 192.

${ }^{288}$ Of note is that the cover of the Carnet d'address, one of the seven books in the French edition, has a red line through the cover which is a photograph of an issue of the newspaper Libération paralleling not only Calle's red lines through Auster's text at the beginning of Double Game but also the maroon ribbon that wraps itself around the book.

${ }^{289}$ Calle, The Address Book, 190.

290 Ibid., 192-193.

291 Ibid., 193.
} 
centimeters, there were also 408 names distributed as follows: $25 \mathrm{~A}, 63 \mathrm{~B}, 35$ C, 38 D, 6 E, 22 F, 18 G, 3 H, 6 I, 5 J, 14 K, 28 L, 42 M, 8 N, 10 O, 21 P. 13 R, $19 \mathrm{~S}, 13 \mathrm{~T}, 1 \mathrm{U}, 12 \mathrm{Y}, 3 \mathrm{~W}, 3 \mathrm{Z} .{ }^{\text {"292 }}$ Calle then (re)classifies this list, this time according to the country of the address: "Italy, $29 \ldots$ The other countries mentioned were: the United States (5), Greece (4), Algeria (3), the Netherlands (3), Switzerland (1), Zaire (1), England (1), Cameroon (1), Austria (1), Portugal (1), Hong Kong (1), Gabon (1), and Germany (1)."293

This is followed by a long and varied description of Pierre D. (the owner (and subject) of the address book). In reading through the list of descriptions, we learn a few details about Pierre D.: "A man who never says, 'Yes Okay,' but 'with pleasure, I'm honored,' with courtesy, lots of affection, bowing and scraping, but funny, very funny; [...] a rather brilliant intellectual who never shows off, who loves minor literature, B-movies, nineteenth century potboilers and opera; [...] who loves Italy, Jerry Lewis, smoking cigars, holding a camera, the circus, fairs, comics, especially Blake and Mortimer; [...]. Someone who would be capable of disappearing without a trace."294 The Address Book offers a fragmentary portrait of a man whom Calle will never meet. The Address Book constructs an identity through others' memories and conflicting accounts of the absent subject. $^{295}$

In 2012 The Address Book was finally published in its entirety by Siglio Press; the same two images bookend the work. In an article discussing the

\footnotetext{
292 Ibid., 189.

293 Ibid., 189.

294 Ibid., 191.

${ }^{295}$ This project resembles more closely Calle's other projects in which memory is more actively foregrounded: Phantoms, Last Seen, L'Erouv de Jerusalem, The Bronx, Doleur exquise.
} 
recently published project, Rozalia Jovanovic writes:

Like all of Ms. Calle's work, this tiny red book conflates fact and fiction. Yes, we're pretty sure that that is Pierre D.'s arm in a still from a television show on which he appeared, because there's a caption that identifies him. But is that worn leather club chair pictured in the book really the one that Pierre D. liked to sit in and smoke a cigar when visiting Myriam V.? Is that postcard of the polar bear really the image on the postcard Pierre D. sent to Jacques D. when he first moved to Norway to lead "an experimental workshop, to go beyond theory"? We'll never know. $^{296}$

In its most recent form, The Address Book, like The Hotel, is set up like a diary, each entry has the date of the original publication and alternates between description, conversations, and quotations from the various people Calle interviews:

\section{WEDNESDAY}

Jacques $D$.

Noon-2pm

...Jacques describes Pierre. He is intelligent, shy, a bit of a dreamer, but by contrast he is very articulate and has a fairly high-level, practical knowledge of cinema....

[...]

"He constantly tells strange, heavy, suspicious stories. He makes them into novels in which he always plays the role of the victim...When he acts out like that, you never know how much is real, how much is fantasy, or whether he does it because he enjoys being a bit ridiculous and entertaining an audience."

Nevertheless Jacques wonders if Pierre has ever been capable of real acts of violence; in his gentle look, there's something that suggests it. I realize that I never asked what colour Pierre's eyes

\footnotetext{
${ }^{296}$ Rozalia Jovanovic, "Sophie Calle's Controversial 'Address Book' Will Be Published as a Book for the First Time," The Gallerist, August 1, 2012 http://galleristny.com/2012/08/sophiecalles-controversial-address-book-to-be-published-in-its-entirety-for-first-time/ (accessed December 15, 2013) I personally like the reference to "Jacques D" and "theory." Could it be Jacques Derrida? In his essay on Calle included in Sophie Calle, M'as-tu vue? Olivier Rolin actually wonders if a postcard addressed to Olivier R, that Calle notes in room 25 in The Hotel is an obscure reference to himself. Olivier Rolin "Beet, Alfalfa, etc.," Sophie Calle, M'as-tu vue? (Munich, Berlin, London, New York: Prestel Verlag, 2003), 140.
} 
are. It is too late; tomorrow will be the last day. I wonder if Pierre already knows our story, if he will resent me.

Maybe I will never know. ${ }^{297}$

It feels as though we are reading a description of Calle's work: "how much is real, how much is fantasy?" This entry is accompanied by a photograph of a polar bear, which does not appear to represent or reconstruct the events described in the text-a seemingly new, and unusual approach for Calle. The Address Book contains a diverse collection of images: a polar bear, abandoned buildings, a television screen in which an arm holds the arm of a seated child, a photograph of Paul Delaroche's painting, The Execution of Lady Jane Grey (a postcard apparently sent by Pierre D. to Charly T., a friend), as well as a few photographic portraits. We will never know how the photographs relate to the texts, or the texts to Pierre D. whose missing presence is made so literal.

\section{Conclusion}

I began this chapter by looking at how the list can be read as a way to inventory, identify, classify, and narrate experiences. I also acknowledge the parallels between the list and the structure and operations of the archive. By focusing on archival absences, by drawing attention to what is missing (yearly gifts, a bottle of Margaux, and the event in The Birthday Ceremony; the guests in The Hotel (1981); and Pierre D. and the project itself in The Address Book (1983)), I suggest that in these projects archival absences and fictions make obvious the impossibility of ever retrieving the full history of an event.

297 Sophie Calle, "Friday September 2, 1983," The Address Book (Los Angeles, California: Siglio Press, 2012), non-paginated. 


\section{CHAPTER FOUR: LIKE THE FEMALE SUBJECT (The Striptease)}

It's complicated what fiction is, because everything is fiction, in a way. ${ }^{298}$

\section{The Striptease}

I was six. I lived on a street named Rosa-Bonheur with my grandparents. A daily ritual obliged me every evening to undress completely in the elevator on my way up to the sixth floor, where I would arrive without a stitch on. Then I would dash down the corridor at lightning speed, and as soon as I reached the apartment, jump into bed. Twenty years later I found myself repeating the same ceremony every night in public, on the stage of one of the strip joints that line the boulevard in Pigalle, wearing a blonde wig in case my grandparents who lived in the neighborhood should happen to pass by. ${ }^{299}$

The Striptease (1979), one of Calle's earliest works, consists of a series of photographs that appear to document Calle's performance (and job) as a striptease artist, apparently in a strip club in Pigalle. The black and white photos are rather stark; they are not particularly aesthetically pleasing, nor erotic. They are barren, and at times feel too close for comfort. This sense of closeness is accentuated by the size of the images; in Double Game they take up the entire page, and when exhibited in a gallery the images of Calle are life-size. In both modes of presentation our proximity to Calle's body forces us to look. This focus on looking is amplified by the fact that, unlike most of Calle's other projects, here there is no narrative that accompanies the images.

In the introduction to their book, Interfaces: Women, Autobiography, Image, Performance (2002), Sidonie Smith and Julia Watson discuss Tracy

\footnotetext{
298 Jill Magid, "Interview with Sophie Calle," in Sophie Calle: The Reader (London: The Whitechapel Gallery, 2009), 43.

${ }^{299}$ Sophie Calle, The Striptease, Double Game, 44-45.
} 
Emin's My Bed (1999), an installation which consists of a real bed with stained and dirty sheets surrounded by dirty ashtrays, cigarette butts, used tissues and condoms, photos, etc. Smith and Watson propose that Emin's work is not only a site that interfaces multiple modes of representation, but also one that "mimics and questions the notion of autobiography's authenticity, teasing the public as well as the art establishment about the limits and possibilities of the artist's representations of 'real' life in autobiographical acts and about the woman artist's essentialized narcissism." ${ }^{300}$ However, as Smith and Watson affirm, Emin's work tests the boundaries of representations of women "in relation to the history of woman as an object of speculation and specularization." ${ }^{301}$ I propose that The Striptease grapples with similar issues. ${ }^{302}$

In The Striptease we see an assortment of shots, ranging from full-body shots to torso only, all taken from various angles, of Calle undressing. The photographer, Thea Westreich, moves around the stage documenting the progressive stages of undress. Initially Calle wears a black dress, high heel shoes, fur, hat, veil and gloves; then a bra and underwear, garter belt, stockings, high heel shoes, and hat; then garter belt, shoes, hat; and finally she is naked with heels, fur, and hat (figure 37, figure 38, figure 39). In each photo she wears a blonde wig. In some photographs we glimpse behind the stage

\footnotetext{
${ }^{300}$ Like Calle, Emin also uses her life as a source for her creative projects, and like Calle's projects, her work is often accused of being "narcissistically self-absorbed," even "trivial and unimaginative." Sidonie Smith and Julie Watson, "Introduction," in Interfaces: Women/ Autobiography/Image/Performance, eds. Sidonie Smith and Julie Watson (Ann Arbor: University of Michigan Press, 2002), 3-4.

${ }^{301}$ Ibid., 4-5.

302 Historically, Calle's work appeared at a time when many female artists were exploring the feminist possibilities of using the body as medium for cultural critique. See Amelia Jones, Body Art/Performing the Subject (Minnesota: University of Minnesota, 1998); and Rebecca Schneider, The Explicit Body in Performance (London and New York: Routledge, 1997).
} 
where we can see other strippers sitting, waiting to perform, as Calle takes off her clothes on stage.
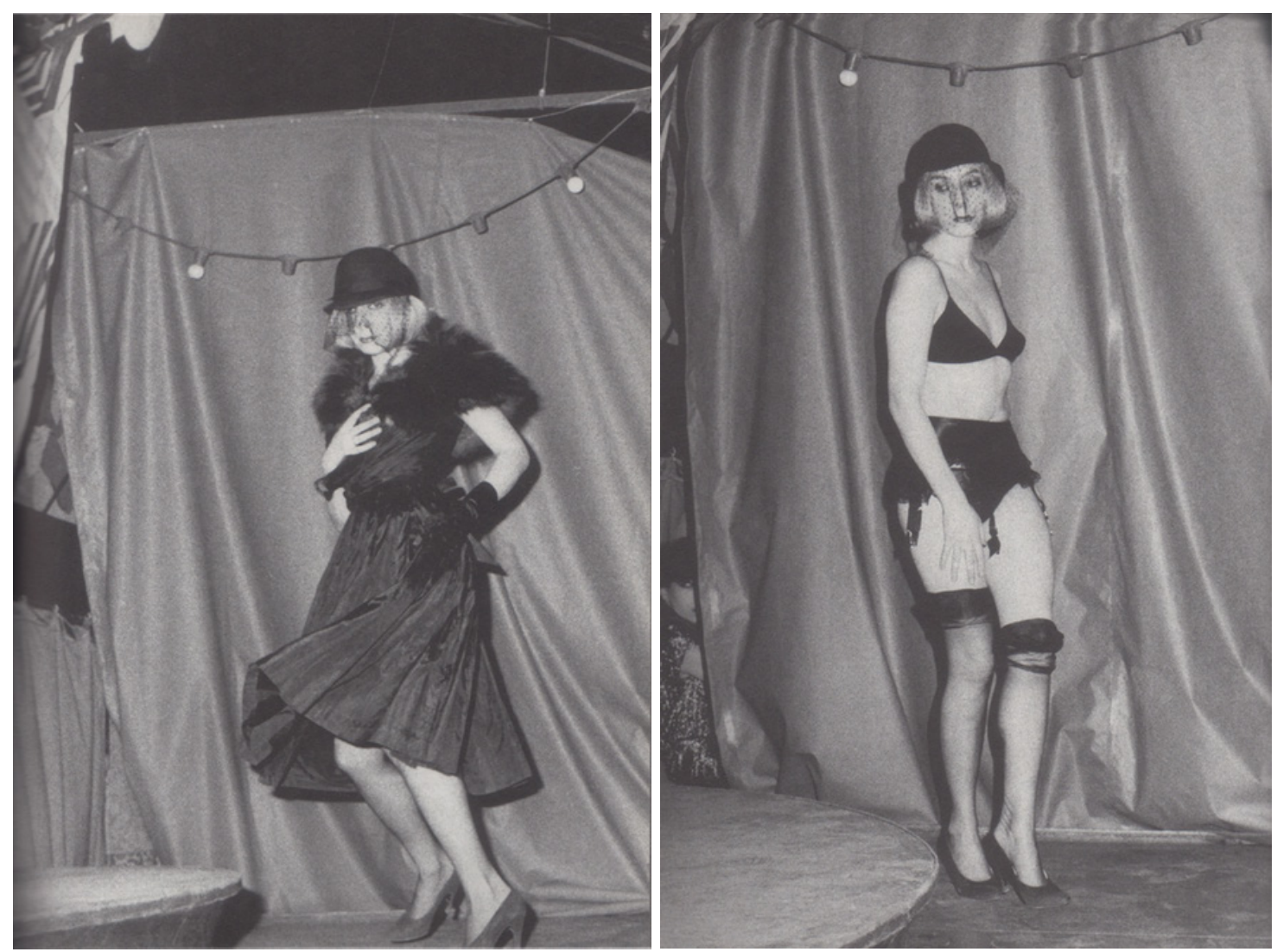

Figure 37. Calle, The Striptease, Double Game, 49

Figure 38. Calle, The Striptease, Double Game, 56. 


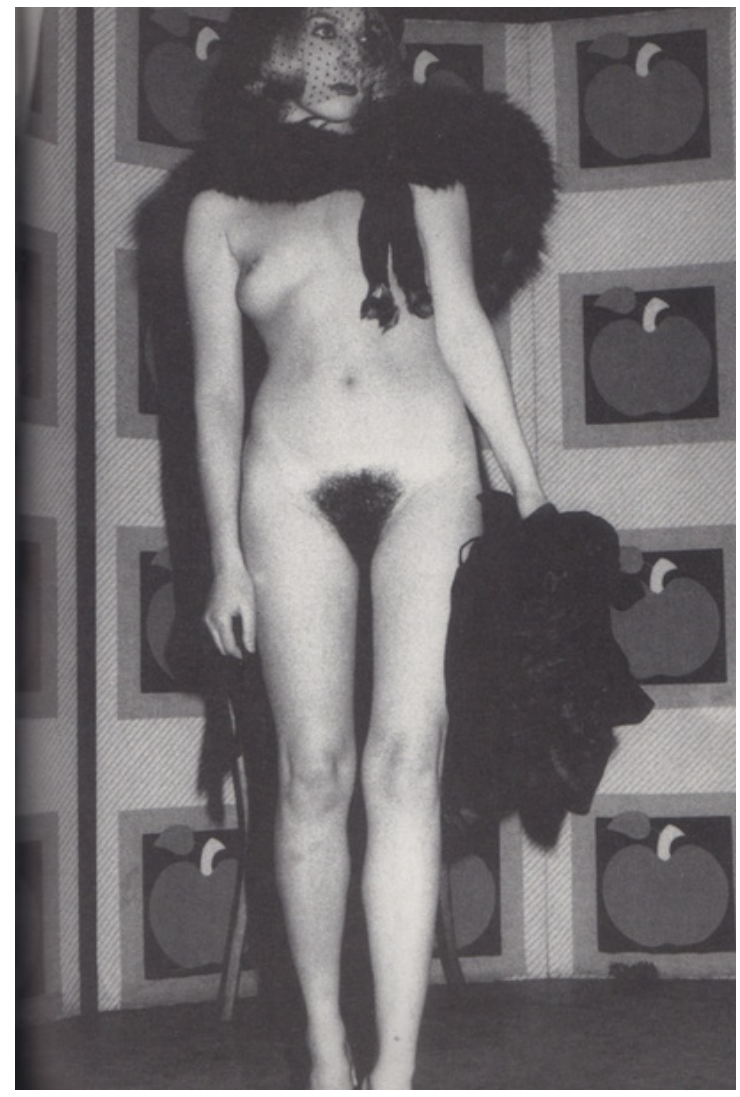

Figure 39. The Striptease, Double Game, 65.

\section{The Female Subject of Desire}

In The Striptease, Sophie Calle, disguised in her wig, performs-for the audience (some of whom are visible in the photographs), the photographer (Thea Westreich), and for the viewer-the female body as object of the gaze. In three of the photographs where we see the audience, and one audience member in particular, watching the show, the act of looking is again emphasized (figure 40). The Striptease encourages discussions of the work through a psychoanalytic lens, one in which voyeurism, exhibitionism, and 
scopophilia come into play. ${ }^{303}$ Psychoanalytic theory can account for the ways in which this project, like Calle's following projects, can be read as an exploration of seeing and being seen, inasmuch as the elements neatly fold into psychoanalytic understandings of how the female body is inscribed, again and again, as a site of (visual) pleasure and desire. ${ }^{304}$

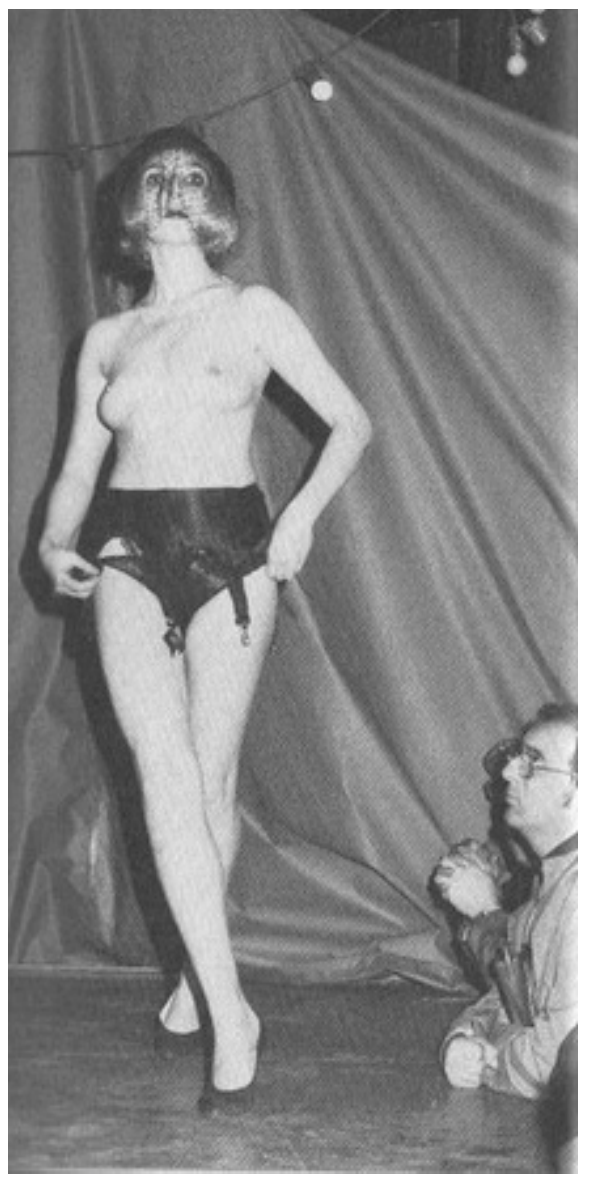

Figure 40. Calle, The Striptease, Double Game, 61.

\footnotetext{
${ }^{303}$ Calle's work, I would argue, is well aware of the consequences of exhibitionism. For a feminist and productive positioning of narcissism see Amelia Jones, "The Rhetoric of the Pose: Hanna Wilke and the Radical Narcissism of Feminist Body Art," in Body Art: Performing the Subject, 151-196 (Minneapolis, London: University of Minneapolis Press, 1998); and Jo Anna Isaak, "In Praise of Primary Narcissism: The Last Laugh of Jo Spence and Hannah Wilke," in Interfaces: Women/Autobiography/Image/Performance, eds. Sidonie Smith and Julie Watson, 49-68 (Ann Arbor: University of Michigan Press, 2002).

${ }^{304}$ Calle's play with psychoanalytic models comes to bear more overtly in her other projects like True Stories, Double Blind/No Sex Last Night, and her installation of True Stories at the Freud Museum: Appointment with Sigmund Freud.
} 
In her discussion of Suite vénitienne, where Calle follows Henri B (a stranger) to Venice, Whitney Chadwick suggests that Calle "unfixes" this gendered history of being looked at by transferring the "male gaze" to her blonde disguised self. ${ }^{305}$ This parallels observations made by Kate Ince, who directly engages Laura Mulvey's formulation of the gaze in her discussion of Calle's work, and suggests that throughout her body of work Calle plays with seeing and being seen by oscillating between voyeurism and exhibitionism as a way to stress the "unstable" relationship between these two polarities. ${ }^{306}$

In Paul Auster's description of Maria's version of The Striptease in Leviathan he also emphasizes this movement between voyeurism and exhibitionism. In Auster's account, Maria appropriates the gaze and enacts this mobility by oscillating between the "object-of-the-look" and the "bearer-of-thelook," 307 as she turns herself into a "nameless figure of desire."

... a piece that eventually became known as The Naked Lady. Maria asked a friend to come along that night and take pictures of her as she performed-not to show anyone, but for herself, in order to satisfy her own curiosity about what she looked like. She was consciously turning herself into an object, a nameless figure of desire, and it was crucial to her that she understand precisely what that object was. ${ }^{308}$

\footnotetext{
${ }^{305}$ Chadwick, "Three Artists/Three Women: Orlan, Annette Messager and Sophie Calle," 111118.

${ }^{306}$ Kate Ince, "Games with the Gaze: Sophie Calle's Postmodern Phototextuality," in The Art of the Project: Projects and Experiments in Modern French Culture, eds. Johnnie Gratton and Michael Sheringham (Oxford, New York: Berghahn Books, 2005), 119-120. Mya Mangawang's doctoral thesis, $\operatorname{Her}(e)$ but not $\operatorname{Her}(e)$ positions The Striptease in a similar manner to this chapter, discussing the ways in which this project can be associated with masquerade and theories of the gaze which she links more closely with Michel Foucault, power, and surveillance. We both draw on Mary Ann Doane and Joan Riviere, as well as Roland Barthes' essay. I hope that the overlap will be productive rather than redundant. Mya Mangawang, Her(e) but not Her(e) (PhD Dissertation, Bryn Mawr College, 2008).

${ }^{307}$ Laura Mulvey, "Visual Pleasure and Narrative Cinema," reprinted in The Feminism and Visual Culture Reader, ed. Amelia Jones, 44-53 (London and New York: Routledge, 2003).

${ }^{308}$ Auster, Leviathan, 65, reprinted in Double Game, 45.
} 
In Auster's version Maria assumes both positions, understanding how the female body, sexuality, and objecthood are constructed within the logic of patriarchal culture. ${ }^{309}$ The space between self and image is shown to be "a complex process of likeness and difference," "of recognition/misrecognition and identification." ${ }^{310}$ This space between self and image is made more obvious in Auster's version of Calle's The Detective. Auster writes that, "she [Maria] studied the photographs of herself and read the exhaustive chronologies of her movements, she felt as if she had become a stranger, as if she had been turned into an imaginary being." ${ }^{311}$ In Auster's version the gap between the signifier (the image of Maria) and referent (Maria) is highlighted; difference, not unity, is emphasized. In her essay "Film and the Masquerade: Theorizing the Female Spectator," Mary Ann Doane writes that looking, "or even simply the fact of seeing as opposed to being seen" offers a way of "usurping the gaze." 312 Doane contends that as such the female body, "masquerading as spectator," then "poses a threat to an entire system of representation." 313

Auster's renaming of this project, The Naked Lady, also seems significant. If we accept Kenneth Clarke's definitions and differences between being naked, without clothes, and being nude, as a form of art, then it would

\footnotetext{
${ }^{309}$ Auster also hints at the ways in which women's self-representation is often described as narcissistic. Mary Ann Doane, writing about film, suggests that: "For the female spectator there is a certain over-presence of the image-she is the image. Given the closeness of the relationship, the female spectator's desire can be described only in terms of a kind of narcissism." Mary Ann Doane, "Film And the Masquerade: Theorizing the Female Spectator," Screen 23, no. 3-4 (1982): 78.

${ }^{310}$ Mulvey, "Visual Pleasure and Narrative Cinema," 47.

${ }^{311}$ Auster, Leviathan, reprinted in Calle, Double Game, 123. Auster's description makes more explicit links to Lacan's mirror stage where the imaginary, linked to the realm of images, leads to misrecognition as the child sees no division between herself and her image. In Auster's version Maria is made aware of the fiction of this unity.

${ }^{312}$ Doane. "Film And the Masquerade: Theorizing the Female Spectator," 83. ${ }^{313}$ Ibid.
} 
seem that Auster is deliberately positioning Maria's project outside of the world of art, conjuring up instead the reality of sex shops and strip clubs. However, Calle's version of this project seems to play with the boundaries between the body in the world of striptease and the body in art historical representation. Traditionally, the female body in art historical representation, and its relation to objecthood, is always already understood as setting up particular forms of knowledge and desire, and putting "in place specific norms of viewing and viewers. ${ }^{314}$ Traditionally and historically, this relationship has been understood in relation to gender, where women are represented as passive objects of the active male gaze. But does Calle's play with codes and conventions as they relate to gender and sexualized bodies actually challenge these normalized understandings of spectatorship and subject/object positions?

Might Calle's use of autofiction offer alternate routes for theorizing selfrepresentation as it relates to spectatorship? Throughout Double Game Calle's competing modes of representation, where photography and text rarely align, help accentuate the "spaces or gaps, ruptures, unstable boundaries, incursions, excursions, limits and their transgressions." ${ }^{315}$ Calle's failure to present a stable and coherent self through the genre and codes associated with autobiography, and her failure to abide by the rules of the game not only reiterate strategies of disobedience and resistance, but also refuse the containment of the female subject. I suggest that Calle's performance on stage exposes fictions and

\footnotetext{
${ }^{314}$ Lynda Nead, The Female Nude: Art, Obscenity and Sexuality (London and New York: Routledge, 1992), 59-60.

${ }^{315}$ Sidonie Smith, "Performativity, Autobiographical Practice, Resistance," in Women, Autobiography, Theory: A Reader, eds. Sidonie Smith and Julia Watson (Wisconsin: University of Wisconsin Press, 1998), 110.
} 
unstable boundaries between life and art, and life and fiction, with a more pronounced focus on the fictions associated with gender and looking. In what ways then might The Striptease both perform and critique the (naked) female subject?

\section{Roland Barthes and "Striptease"}

In his essay, "Striptease," included in Mythologies, Roland Barthes acknowledges a certain paradox within striptease and suggests: "Parisian striptease-is based on a contradiction: Woman is desexualized at the very moment she is stripped naked." ${ }^{316}$ Barthes also articulates the performative nature of striptease and hints at—but never fully articulates—the ways in which striptease stages womanliness as masquerade, and is also intimately connected with the Freudian fetish. For Barthes, stripping "hides nudity, and smothers the spectacle under a glaze of superfluous yet essential gestures, for the act of becoming bare is relegated to the rank of parasitical operations carried out in an improbable background." 317

Barthes argues that the reiteration of codes is important for striptease; including a "series of coverings placed upon the body... as she pretends to strip it bare." ${ }^{118}$ These "codes" are established immediately in the first image of The Striptease, where we see the strippers on stage in their "costumes" already making explicit and literal their masquerade (figure 41). Barthes argues that these layers transport the body into a "world of legend or romance" (read

\footnotetext{
${ }^{316}$ Roland Barthes, "Striptease," Mythologies, trans. Annette Lavers (London: Paladin Books, 1973 (1957)), 84.

317 Ibid., 86.

${ }^{318}$ Ibid., 84.
} 
fiction), which aims to establish "the woman right from the start as an object in disguise." ${ }^{319}$ In Calle's performance there is a double-marking of the body in disguise; not only do the "coverings" disguise the object/body underneath the layers, but Calle's use of the wig can be read as a second level of disguise-to remain unseen—in case her "grandparents who lived in the neighborhood should happen to pass by." 320

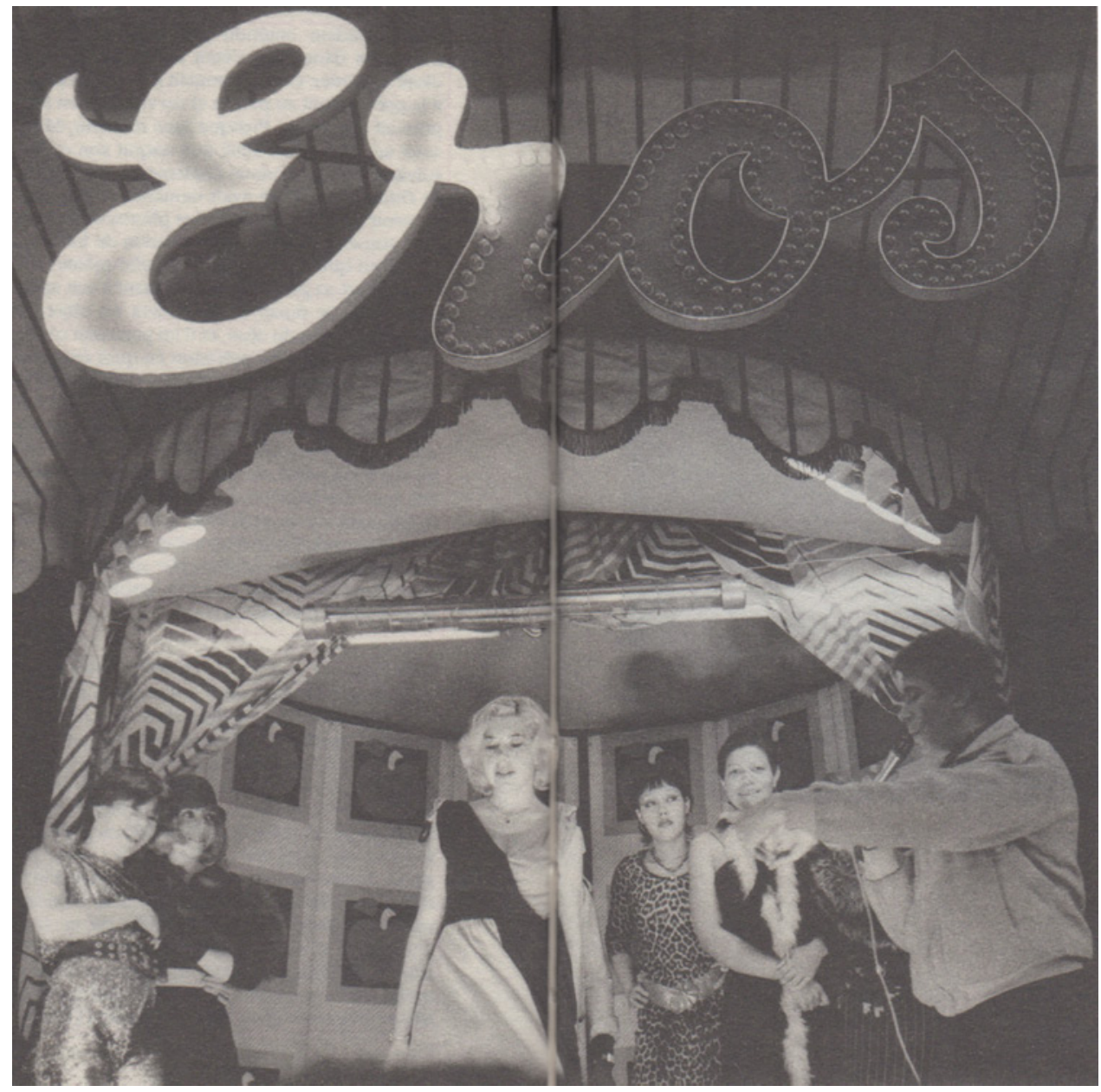

Figure 41. Calle, The Striptease, Double Game, 46-47.

Source: Sophie Calle, Le strip-tease, Les panoplies (Livre III), Doubles-jeux (Arles: Actes Sud, 1998), 22-23.

\footnotetext{
${ }^{319}$ Ibid.

${ }^{320}$ We encounter the wig in Suite vénitienne, and Days Under the Sign of $B, C$ and $W$, but the wig is only used sporadically rather than as a consistent marker of masquerade. There is no mention of the wig in the other projects included in Double Game.
} 
In this project, Calle (re)enacts the performative codes that establish this theatrical performance as a striptease through the use of "classic props" (garter belt, high heels, veil, fur collar) and "ritual gestures" (such as the sitting on the chair to remove her stockings) (figure 42). Her use of props, this "spectrum of adornment," Barthes argues, "constantly makes the living body return to the category of luxurious objects." ${ }^{321}$ And, I argue, these "classic props" and "ritualized gestures" also work to expose how womanliness can be read as a "decorative layer"-as masquerade. ${ }^{322}$

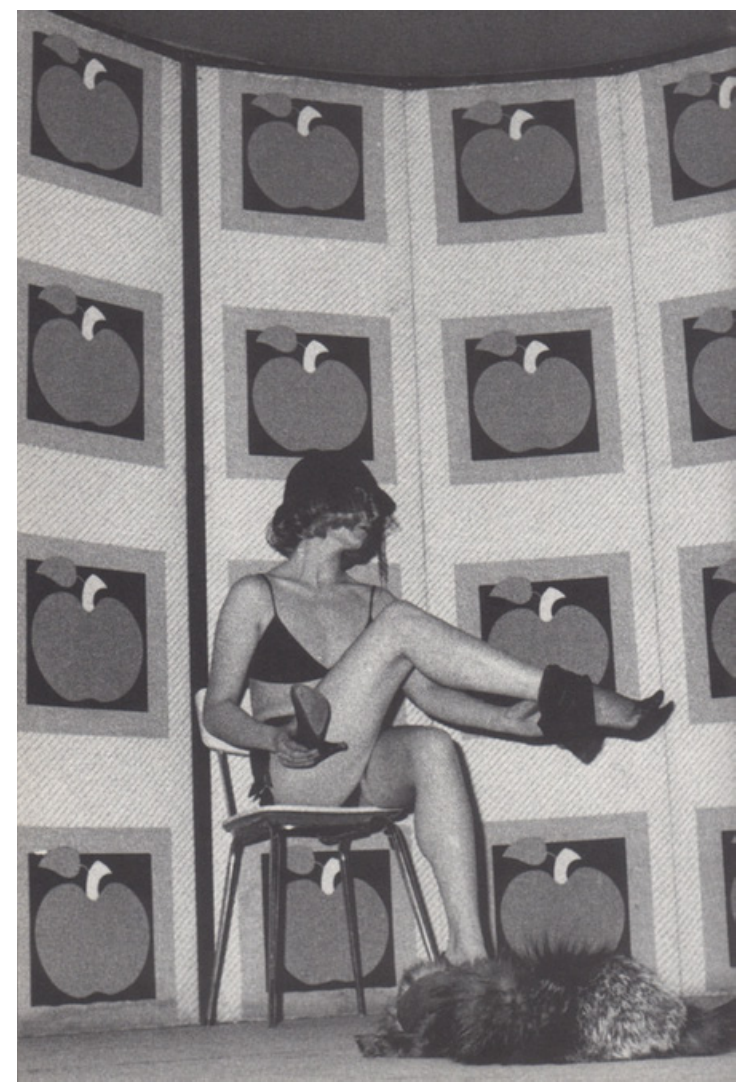

Figure 42. Calle, The Striptease, Double Game, 58.

${ }^{321}$ Barthes, "Striptease," 85.

${ }^{322}$ Doane, "Film And the Masquerade: Theorizing the Female Spectator," 81. 


\section{As Masquerade}

In her influential essay, "Womanliness as Masquerade," written in 1929, Joan Riviere looks at the ways in which masquerade becomes "a compulsive reversal of her (woman's) intellectual performance." "W23 "Womanliness therefore could be assumed and worn as a mask both to hide the possession of masculinity and to avert reprisals expected if she was found to possess it."324 Throughout Double Game, Calle not only investigates female subjectivity, but takes up positions that have been historically reserved for men: as author, as detective, as stalker, as criminal, as spy. Her work also plays with forms associated with the authoritarian and patriarchal imposition of law, order, and containment, such as the book, the archive, and autobiography. Calle's work thus plays with her "womanliness" as a mask to disguise her threat, like "a thief who will turn out his pockets and asks to be searched to prove that he has not stolen the goods." ${ }^{325}$

Feminist literary critic Leigh Gilmore writes:

Finally at the scene of writing, each woman struggles with inherited biographical narratives constitutive of the official histories of the subject. When does she take up the sanctities of official narratives and when does she set them aside? How far does she accommodate inherited forms, the official and officious calls to a specific subjectivity, and how far does she stretch the form to fill her own needs and desires? What are the pressure points she puts on traditional autobiography as it presses her into a specific kind of autobiographical subject? ${ }^{326}$

\footnotetext{
${ }^{323}$ Joan Riviere, "Womanliness as Masquerade," reprinted in Feminist Theory: A Reader, eds. Wendy Kolmar and Frances Bartowski (New York: McGraw Hill, 2013) 147.

324 Ibid.

${ }^{325}$ Ibid.

${ }^{326}$ Gilmore, Autobiographics: A Feminist Theory of Women's Self-Representation, 23.
} 
Gilmore encourages a positioning of contemporary writers and autobiographical acts as "occasions for searing cultural critique as autobiographical subjects vigorously interrogate cultural subjectivities." ${ }^{327}$ Calle's photographs and subsequent narratives begin to deconstruct "inherited forms" associated with the striptease, by exposing their operations. Within the context of Double Game, Calle's performance also challenges the boundaries, limits, and possibilities of artist's re-presentations of "real" life.

Performance theorists Peggy Phelan and Amelia Jones both propose that one of the important aspects of performance is the inability to secure the relation between the body and subjectivity. ${ }^{328}$ The Striptease not only reveals its own construction—by making more obvious that this erotic spectacle is an illusion—but also highlights the space between subjectivity and the body as object. This space, in turn, reiterates that representations of autobiographical acts cannot be taken as a guarantee of an authentic, coherent self. Like earlier feminist performance practices The Striptease works "to displace and provoke the spectator's identification with the illusionary and ideological functions of representation." 329

Amelia Jones argues that many artists, particularly those working in "the period since 1970 or so, have seized on this paradox of self-portraiture photography: the way in which it both delivers and endlessly defers the identity

\footnotetext{
327 Ibid.

328 Jones, "'Presence' in Absentia: Experiencing Performance as Documentation," 13. Jones is drawing on Kathy O'Dell's observations regarding Peggy Phelan's positioning of the body in performance, which flaunts the body as a lack or loss-as resistance against a certain plentitude associated with selfhood. Phelan, "The Ontology of Performance," in Unmarked: The Politics of Performance, 150-151.

${ }^{329}$ Amelia Jones, "Postmodernism, Subjectivity, and Body Art," in Body Art/Performing the Subject, ed. Amelia Jones (Minnesota: The University of Minnesota Press, 2008), 24.
} 
of the artistic subject...."330 These strategies, Jones argues, have "a particular force for women artists, who struggle to articulate themselves as 'authors' rather than 'objects' of artistic creation and to intervene in the structures of voyeurism by which women's bodies are subordinated to a gaze that is aligned with male subjects." 331

\section{As Failure}

This failure of the body in performance to secure the relationship between the body and subjectivity is paralleled in the failure of the erotics of striptease in Calle's work. This failure is set up in the very first image, which shows a stage, curtains drawn to the side, and five women standing underneath a half-lit sign that reads "Eros." However, only the $\mathrm{E}$ and part of the $\mathrm{R}$ are lit, the rest of the letters remain in darkness, a sign that announces the inability of this scenario to render the scene fully and completely under the sign of Eros (erotic love) (figure 41). On the right hand side there is a male announcer with his (phallic)

microphone in hand. The women, including Calle, are dressed in a collection of leopard-skin dresses, boas, veil, and gloves, the markers and costumes of the striptease. This photograph sets up the ways in which this project speaks to the disjuncture between image, subjectivity and sexuality and the inability of the photograph, and by extension the performance, to deliver its subject. The photographs that reveal the other women waiting disinterestedly back stage as

\footnotetext{
${ }^{330}$ Amelia Jones, "Performing the Other as Self: Cindy Sherman and Laura Aguilar Pose the Subject," in Interfaces: Women/Autobiography/Image/Performance, eds. Sidonie Smith and Julie Watson (Ann Arbor: University of Michigan Press, 2002), 69.

${ }^{331}$ lbid.
} 
Calle takes off her clothes help highlight, in a somewhat playful way, the striptease as spectacle and illusion.

\section{Proximity and Distance}

The Striptease plays with inherited dichotomies associated with looking: active/passive, subject/object, but also proximity and distance. In Leviathan, this is made more explicit as Maria's performance and subsequent relationship to the resulting images stress her mobility in which she appropriates the "male" gaze to look at the photographs of herself.

In her article on "Film and the Masquerade," Mary Ann Doane draws on Christian Metz who argues that the voyeur must maintain distance between himself and the image. Metz writes, "It is true of all desire that it depends on the infinite pursuit of its absent object, voyeuristic desire, along with certain forms of sadism, is the only desire whose principle of distance symbolically and spatially evokes this fundamental rent." ${ }^{332}$ Spectatorial desire is aligned with a certain spatial configuration, one in which distance must be maintained.

Distance and spectatorial desire is also critical for The Detective where Calle consciously acts out her role as the female subject and object of the gaze: "I want to show 'him' the streets, the places I love. I want 'him' to be with me as I go through the Luxembourg, where I played as a child and where I received my first kiss in the spring of $1968 .{ }^{333}$ In Suite vénitienne, now the one who watches, Calle catches herself playing out the opposing viewing position where

\footnotetext{
${ }^{332}$ Christian Metz, "The Imaginary Signifier," Screen 16, no. 2 (Summer 1975): 61. Quoted in Mary Ann Doane, "Film And the Masquerade: Theorizing the Female Spectator," Screen 23, no. 3-4 (1982): 78.

${ }^{333}$ Calle, The Detective, 126.
} 
desire is projected onto Henri B: "I must not forget that I don't have any amorous feelings toward Henri B." ${ }^{334}$ Later in Suite vénitienne when Henri B discovers Calle, and this distance between them dissolves, he says: "Your eyes, I recognize your eyes; that's what you should have hidden." 335 The interplay between distance, desire, and seeing is emphasized. Near the end of Suite vénitienne Calle writes: "Did my adventure with him come to an end because he discovered me, because he knows?"336 Calle's projects continually mark out and test the affiliation between seeing and knowing. ${ }^{337}$

\section{As Fetish}

The fetish seems like the most obvious way in which Calle marks this play between seeing and knowing, absence and presence. Barthes describes the Parisian striptease as "a spectacle based on fear, or rather pretense of fear." This echoes Freud's understanding of the fetish, which was "a substitute for the woman's (the mother's) penis that the little boy once believed in and-for reasons familiar to us-does not want to give up." ${ }^{339}$ The fear of castration forces the little boy to disavow his mother's lack of a penis. The Freudian fetish—and its links to a patriarchal reign—is a prime example of doubling: of

\footnotetext{
${ }^{334}$ Calle, Suite vénitienne, 89.

335 Ibid., 106.

336 Ibid., 116.

${ }^{337}$ Performance is often read as a way to challenge "ocular hegemony" which "assumes the visual world can be rendered knowable before the omnipotent gaze of the ' $\mathrm{l}$ ' of the Western Cogito." Kobena Mercer, quoted in Rebecca Schneider, "In the Meantime: Performance Remains," in Performing Remains: Art and War in Times of Theatrical Reenactment (London and New York: Routledge, 2011), 98.

${ }_{338}$ Barthes, "Striptease," 84.

${ }^{339}$ Sigmund Freud, "Fetishism," in Sigmund Freud, Volume Seven: Three Essays on Sexuality and Other Works, trans. James Strachey (England: Penguin Books Ltd, 1977 (1952)), 352.
} 
absence and presence, acknowledgement and disavowal, desire and loss. ${ }^{340}$ The fetish for Freud was a "token of triumph over the threat of castration and a protection against it." ${ }^{341}$ Classic examples of the fetish are high heel shoes, fur, velvet, gloves, etc., objects appropriated and used as props in Calle's performance. In psychoanalytic theory these objects not only stand in for and act as a symbolic substitute for Calle's missing phallus, but also help complete the illusion of plentitude that the fetishist believes in. Thus Calle's use of fetish objects can be read as another strategy that draws attention to the impossibility of a unified and coherent subject.

\section{As Vocation}

In an interview in The Guardian titled "Sophie Calle: stalker, stripper, sleeper, spy," Calle speaks specifically about taking a job as a stripper and the photographs taken by Thea Westreich. Calle discusses her father's reaction to the photographs: "He said to me, 'Never show them to anybody."'342 Against her father's wishes, Calle published La fille du docteur (1991), "a book of these photos, juxtaposed with cards her parents had received from friends when their daughter was born. ${ }^{343}$ La fille du docteur exists as a limited edition (230

\footnotetext{
340 Judith Rugg also discusses Calle's objects in Appointment in relation to fetishism (high heeled shoes, wigs, etc.). Judith Rugg,"Sophie Calle's Appointment at the Freud Museum: Intervention or Irony?" in New Practices-New Pedagogies: A Reader, ed. Malcolm Miles (London, New York: Routledge, 2005), 51.

${ }^{341}$ Freud, "Fetishism," 353.

${ }^{342}$ Stuart Jeffries, "Sophie Calle: stalker, stripper, sleeper, spy," The Guardian, Culture>Art and Design>Art, Wednesday 23 September 2009 http://www.theguardian.com/artanddesign/2009/sep/23/sophie-calle (accessed April 24, 2014). ${ }^{343}$ Ibid.
} 
copies), leopard-skin covered volume in collaboration with photographer Thea Westreich. $^{344}$

This story of Calle's father's reaction, real and/or fictional, speaks to the relationship between stripping, seeing and being seen, but also situates the act as part of a larger social, public, and national network. In his essay on striptease, Roland Barthes discusses stripping as a vocation and devotes time to listing the various levels of stripping, from amateur to semi-professional. Barthes observes that the professionalization of stripping in France works to "give striptease a reassuring petit-bourgeois status." ${ }^{345}$ Barthes suggests that stripping in France integrates itself into the "world of the public, is made familiar and bourgeois," ${ }^{346}$ through spectacle. Barthes ultimately acknowledges how stripping becomes a way of control and containment of the female subject through the reiteration of codes and modes associated with hegemonic discourse and strategies. Thus stripping, like autobiography, emerges as a way of "constituting and regulating" female (bourgeois) subjects. In the opening page to his essay on wrestling, Barthes maintains that for the public, "what matters is not what it thinks but what it sees." 347

\section{As Violence}

In the same interview in The Guardian, Calle continues: "I asked myself, 'Am I refusing [to be a stripper] just because other feminists would oppose me?' And I realised I feared being psychologically destroyed by the look of others. But why

\footnotetext{
${ }^{344}$ Description on the university of Wisconsin Library web site: http://search.library.wisc.edu/items/GKQE7Z7ACKJWM84 (accessed April 24, 2014).

345 Barthes, "Striptease," 86.

346 Ibid., 87.

${ }^{347}$ Roland Barthes, “The World of Wrestling," Mythologies (London: Paladin, 1973) 13.
} 
did I think it OK to be a nude model for artists?" ${ }^{348}$ This quote speaks to both the importance of the look and reinforces the relationship between nudity and art historical representation in which the naked female is continually objectified in representation. However, this quote also hints at the violence inherent in the objectification of women.

Calle makes reference to being a nude model for a drawing class in $\mathrm{La}$ lame de rasoir, included in Des histoires vraies. In La lame de rasoir, the connection between nudity, erotics, seeing and violence is made more explicit. La lame de rasoir consists of a photograph of a drawing of a naked woman, which has been sliced and is held together with scotch tape (figure 43). The text reads:

I posed nude everyday for a drawing class, from 9am to 12 noon. And each day, a man who was always seated in the first row, on my far left drew me for three hours. At noon he would take a razor blade out of his pocket and compulsively slash the drawing he had made. I would watch. Then he would leave the room. The drawing would remain on the table as evidence. This was repeated every day for 12 days, on the thirteenth day, I didn't go to work. ${ }^{349}$

Again Calle narrates the interconnectedness between looking, being looked at—as object of the gaze—and violence.

\footnotetext{
348 Jeffries, "Sophie Calle: stalker, stripper, sleeper, spy."

${ }^{349}$ Sophie Calle, La lame de rasoir, Des histoires vraies, English translation from Appointment with Sigmund Freud (London: Thames and Hudson, 2005), 105.
} 


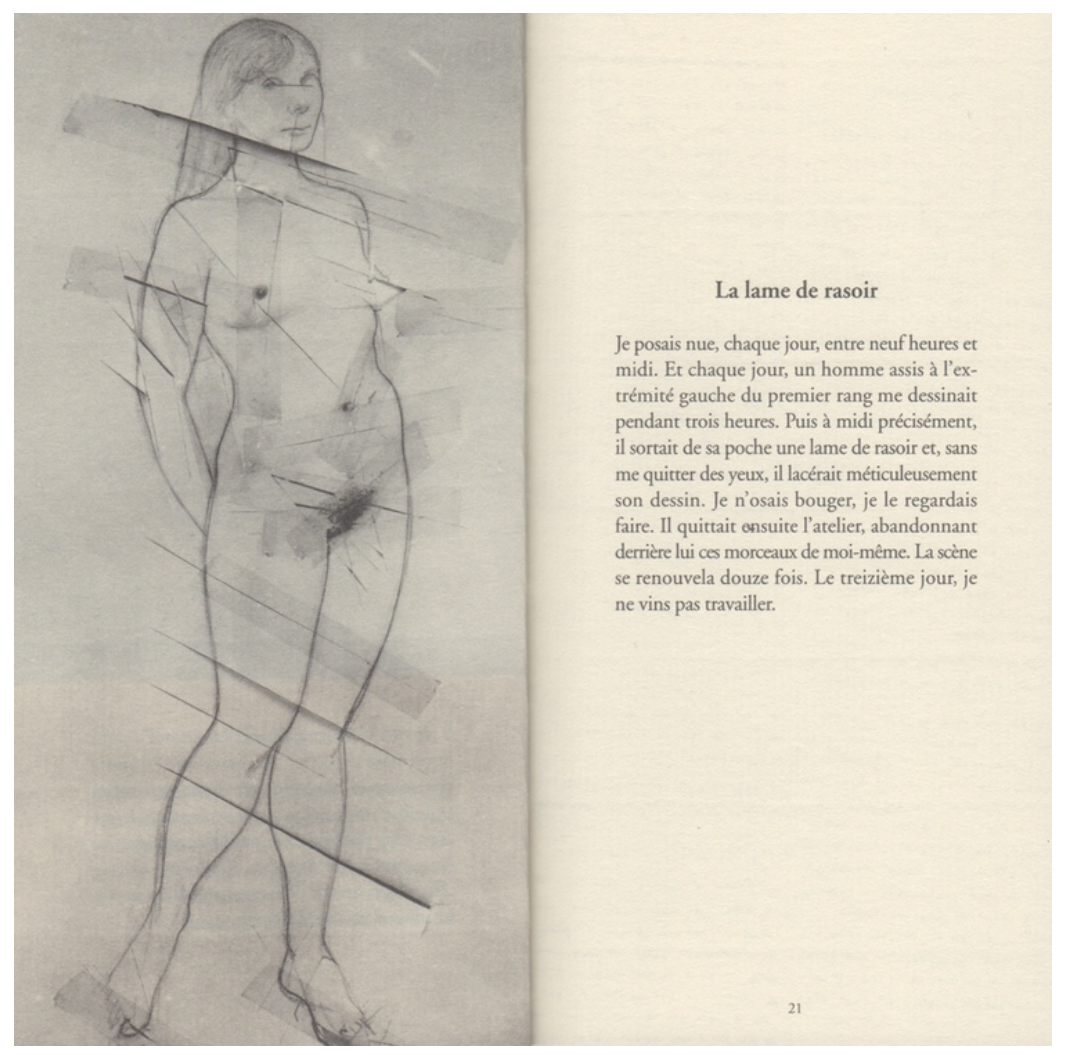

Figure 43. Sophie Calle, La lame de rasoir, Des histoires vraies + dix (Arles: Actes Sud, 2002), 20-21.

This relationship between art, nudity, and violence occurs again in relation to The Address Book, originally published in the French newspaper Libération. Calle's project consisted of a series of observations and quotes from the people listed in a man's address book that she found on the street. It is well known that after publishing The Address Book in the newspaper, the owner of the address book (Pierre Baudry) returned to Paris to find that he was the subject of Calle's project. On September 28, 1983, the outraged Baudry wrote a letter to the editors denouncing Calle's acts. The letter would appear to confirm that Calle's project was not all constructions and fictions:

...d'une intrusion dans ma vie privée. Que, dans ces articles, je sois resté formellement anonyme, n'y change pas grand 
chose: j'y suis XXXXX [I can't read the word here] reconnaissable, a prévue que tous les gens qui me connaissent m'ont reconnu, et il y'a dans ces textes, des détails de ma vie et de mes projets que j'durais souhaité voir rester intimes.

[...an intrusion into my private life. In the articles I remain anonymous, but that doesn't change anything: I am recognizable, and I am sure that people who know me will also recognize me; and in these texts there are details about my private life and my projects that I would have liked to have remained private. $]^{350}$

The newspaper also agreed to publish a photo of Calle in the nude.

"Respectons son anonyme [Respecting her anonymity]" the face is removed from the image, whited out (figure 44). Baudry writes : "Oui, je me choque moimême, parce que je fais violence à quelqu'un. [Yes, I even shock myself, because I am being violent towards someone]." ${ }^{1351}$ Calle is mentioned in the title of Baudry's letter: "Calle, calepin, calembredaines [Calle, notebook, nonsense]," thus the erasure of her face is not about respecting anonymity but rather can be read as gratuitous violence enacted upon the "anonymous," naked female body.

\footnotetext{
${ }^{350}$ Pierre Baudry, " Droit de réponse à Sophie Calle: Calle, calepin, calembredaines," "Libération, mercredi le 28 septembre, 1983 (translation mine).

${ }^{351}$ lbid.
} 


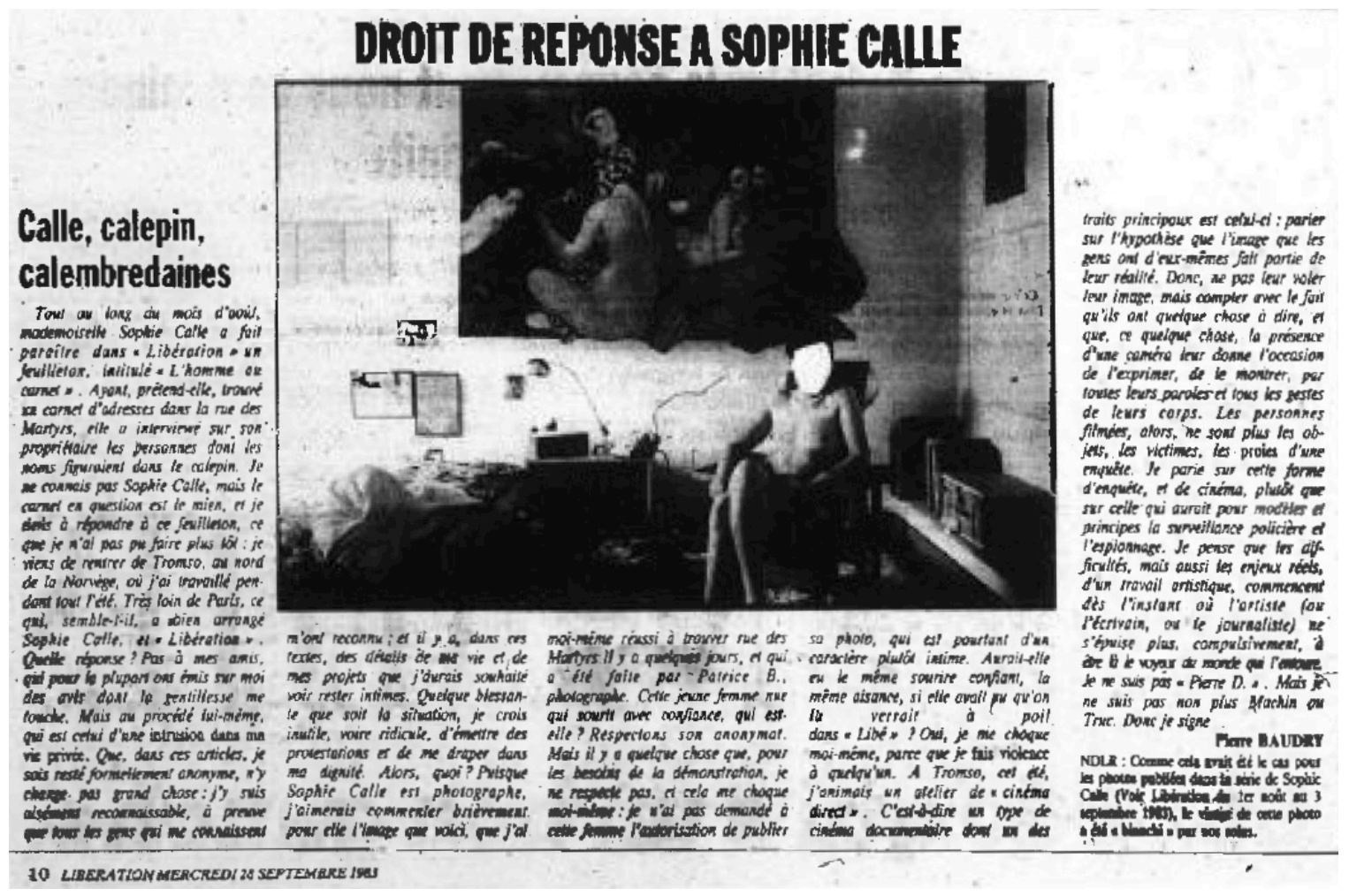

Figure 44. Pierre Baudry, "Droit de réponse à Sophie Calle: Calle, calepin, calembredaines," Libération, mercredi le 28 septembre, 1983, 10.

As I have argued in other chapters, Calle's photographs often present the events in a way that accentuate photography's association with forensics or crime scene photographs, banal images reminiscent of newspaper tabloid photos, Weegee, and even Eugène Atget. Baudry's letter links photographic evidence and information gathering with violent acts, not only in relation to crime scene photographs and forensics, but as aggressive acts in themselves. This is reinforced by Yve-Alain Bois' description of Calle's photographs. Bois 
suggests: "she's only interested in the predatory and voyeuristic aspects of photography, in its sadistic nature."352

The body, violence, and their relationship with photography are made more explicit in The Striptease. The final image of this project is a black and white photograph of Calle dressed in a dark dress, lying on a floor, surrounded by a collection of objects (fur wrap, shoes, tubes of cream, packets of cigarettes), eyes closed. Missing, is her wig (figure 45). The photograph is accompanied by this text: "One January 8,1981 , as I was sitting on the only chair in the trailer, one of my colleagues, to whom I refused to give my seat, tried to poke out my eyes with her high heel and ended up kicking me in the head. I lost consciousness. During the fight, she had, as the ultimate stage of stripping, torn off my blonde wig. This was to be my last performance in the profession." ${ }^{353}$ This project, I propose, disrupts circuits of identification with the naked body as erotic spectacle through the inclusion of this last photograph, turning what is set up to be an erotic encounter into a crime scene where the mask of womanliness (and disguise) has literally been ripped off.

\footnotetext{
${ }^{352}$ Bois, "Character Study," 85.

${ }^{353}$ Calle, The Striptease, 67.
} 


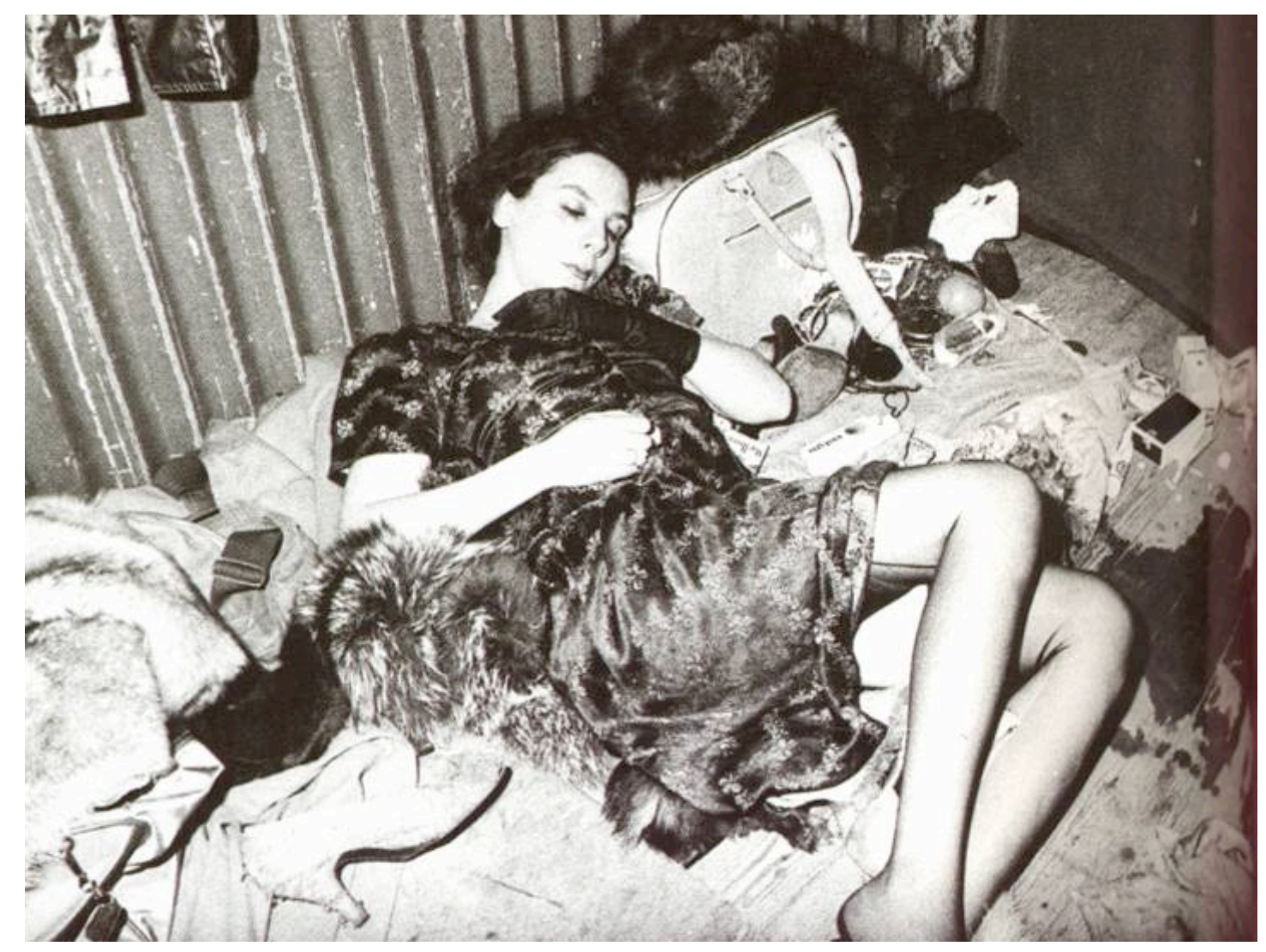

Figure 45. Calle, The Striptease, Double Game, 66-67.

Like the photographs in The Hotel, Suite vénitienne, and The Chromatic Diet, Calle's final photograph sits uncomfortably between documentary and illustration, between evidence and conjecture. Like the photographs in Vito Acconci's Following Piece, as described by Buskirk and Gratton, this last photograph does not appear to authenticate the narrative, or at least it serves to highlight the constructed nature of Calle's narrative. As in The Chromatic Diet, this last photo forces us to rethink the status of the photos that came before as we now begin to doubt the events as described. Would the photographer, Thea Westreich, merely stand back and take photographs had Calle been attacked by another stripper? Or does this image, paradoxically, reinforce the 
documentary status of the photograph by playing out the role of the documentary photographer who does not intervene? Calle's accounts continually reinforce autofiction's reliance on doubt, despite her use of the photograph as evidence.

\section{Sophie Calle is Suspect}

Calle's employment of detective fiction, photographic evidence, and fictional traces plays out in all her projects, and the reader gets caught up in playing the role of the detective, trying to find the author and the criminal, looking for clues, trying to decipher truth from lies. We are witness to the scene of the crime, but it seems that once again Sophie Calle is (a) suspect.

In his essay on Calle's photographs, Jean-Paul Guichard argues that not only does the last photograph appear staged, as I have suggested, but that there are other clues in the photographs of The Striptease that indicate that the whole enterprise has been staged:

Dans un univers de spectateurs mâles et de femmes exploitées, un photographe-fût-il une femme-peut difficilement venir, sans prise de contact préalable, réaliser des photographies au vu et au su des spectateurs. De plus, la variété des angles de prise de vues implique que I' «amie» photographe se déplace aisément le long de la scène, ce qui est encore moins vraisemblable. Si l'on observe bien les éclairages, les ombres projetées et la direction de la lumière, les clichés de Sophie Calle font plus penser à une scène reconstituée en studio qu'à une scène prise en conditions réelles.

[In a world of male spectators and exploited women, a photographer-even if it was a woman-would have difficulty taking photographs openly, without prior contact with the spectators. In addition, the variety of camera angles and points of view taken by the photographer "friend", who is able to move along the length of the stage, seems even less likely. 
If we carefully observe the lighting, shadows cast and direction of light, the photographs of Sophie Calle make us think that these were reconstituted in a studio rather than the conditions they describe.] ${ }^{354}$

I am not convinced by Guichard's observations, but I do notice inconsistencies in the photographs. For example, in the first image, Calle wears a different dress than in the subsequent photos; it is the same dress she is wearing in the very last image... a gap in the apparent unfolding of time, where we assumed the photographs to be a chronological account of a durational performance. Perhaps this is an amalgamation of performances, of repetition as difference? In Des histoires vraies this experience-her job as a striptease artist-is divided into two separate narratives: one titled Le strip-tease and the other, Le talon aiguille. The first consists of a photograph of Calle topless onstage in heels, corset, underwear, hat, veil, and wig. The audience, who appear very close to the stage, is also visible. This is the same photograph from page sixtyone in Double Game. This photograph is accompanied by the same introduction to this project.

The second account, Le talon aiguille, presents this last photograph used in The Striptease of Calle lying in her trailer, knocked out; but the beginning of this narrative differs slightly from the one we are reading: "I was 27 years old [a year different from our story]. I was hired as a striptease artist in a travelling carnival, which was set up for Christmas holidays at the corner of boulevard de Clichy and rue des Martyrs. I was supposed to undress 18 times a day between

\footnotetext{
354 Jean-Paul Guichard, "Poker menteur: de la photographie comme preuve de l'existence de Sophie Calle," Traces photographiques, traces autobiographiques, eds. Danièle Méaux et JeanBernard Vray (St-Étienne: Publications de l'Université de Saint-Étienne, 2004), 79 (translation mine).
} 
4pm and 1am. On January 8, 1981, as I was sitting on the only chair in the trailer...."355

While this narrative does not contradict the account in Double Game, it does offer a slightly different version of the events. As I have outlined in previous chapters, this difference points to undecideability—-to our inability to determine the actuality of the events described. The photographs in The Striptease fail to deliver the subject (Sophie Calle), erotic desire, but also the "indexical promise of photography." ${ }^{356}$ Calle's use of autofiction reinforces the way in which the photograph fails to deliver the author/artist and thus fails to deliver "a subject, in turn, who promises to secure meaning by providing the interpreter with access to authorial intention." 357

\section{Conclusion}

The continual recycling of stories and images in Calle's work offers endless possible narratives and provides a variety of subject positions for Sophie Calle: as fictional character, striptease artist, chambermaid, detective, and criminal, etc. The Striptease enacts and performs the masquerade of femininity, making explicit striptease's reliance on codes and the operations of the fetish and masquerade. The Striptease reiterates the codes and conventions associated with erotic spectacle only to reveal its artifice, its failure, as well as its connection to violence.

\footnotetext{
${ }^{355}$ Sophie Calle, Le talon aiguille, in Des histoires vraies, English translation from Appointment with Sigmund Freud (London: Thames and Hudson, 2005), 25.

356 Jones, "Performing the Other as Self: Cindy Sherman and Laura Aguilar Pose the Subject," 69.

${ }^{357}$ lbid.
} 
By underlining the separation between subjectivity and the body, Calle also marks out the contingency of the subject, "which seeks to undermine the conventional Cartesian conception of the (implicitly male) subject as unified and coherent for himself, as the unified viewer at the centre of a wholly selfpossessed 'gaze'."358

According to Shirley Jordan,

Autofiction has been central to the proliferation of self-narrative experiment in France for over thirty years, burgeoning from debates about the impossibility of autobiography as traditionally conceived, dissolving generic boundaries, and reaching across contexts and media. By definition unstable, prospective rather than retrospective, autofiction is appropriate to the unsettled post-Freudian subject whose confidence is placed in the 'actvalue' rather than the 'truth-value' of narrative. ${ }^{359}$

Calle's project not only challenges the way in which narrated autobiographical acts are understood as a guarantee of the author as authentic, coherent, fixed, and true, but offer another way of making uncertain (and always incomplete) the represented status of the autobiographical autofictional subject.

\footnotetext{
${ }^{358}$ Ibid., 70.

${ }^{359}$ Shirley Jordan, "État Présent: Autofiction in the Feminine," French Studies, LXVII, 1 (2012): 7.
} 


\section{CHAPTER FIVE: CONSTRUCTING AN ARCHIVE (Gotham Handbook)}

... I wanted to keep it open enough so that you could find your own way through the ideas. ${ }^{360}$

\section{Gotham Handbook}

Since in Leviathan, Paul Auster has taken me as the subject, I imagined swapping roles and taking him as the author of my actions. I asked him to invent a fictive character which I would attempt to resemble. I was, in effect, inviting Paul Auster to do what he wanted with me, for a period of up to a year at most. Auster objected that he did not want to take responsibility for what might happen when I acted out the scripts he had created for me. He preferred to send me "Personal Instructions for SC on How to Improve Life in New York City (Because she asked)." I followed his directives. This project is entitled Gotham Handbook. ${ }^{361}$

This project sits alone in the third section of Calle's book: "One of the many ways of mingling fact and fiction, or how to become a character out of a novel." The first seven pages consist of a hand-written letter from Paul Auster to Sophie Calle, along with six typewritten pages that describe his project (figure 46, figure 47). Auster's project is dated March 5, 1994. There are a few annotations to Auster's typewritten pages, and while they might work to remind us of Calle's annotations to Auster's Leviathan at the start of Double Game, here they appear to be written by Auster rather than Calle, and are linked more

\footnotetext{
${ }^{360}$ Paul Auster, Letter to Sophie Calle, Gotham Handbook, Double Game, 237. In Gotham Handbook, SC, S.C., and Sophie Calle are used by the different authors at different times. I have replicated the way they appear in the text.

361 Sophie Calle, Gotham Handbook, Double Game, 234-235. In French this project is entitled Gotham Handbook: New York, mode d'emploi, similar to George Perec's La Vie mode d'emploi (1978). There are also similarities with Perec's other work, Species of Spaces (1974), which demonstrates an interest in space and the everydayness of space. Like Calle, Perec notes observations, ideas, patterns etc. More specifically, The Street, part of Species of Spaces contains "practical exercises," similar to Auster's instructions: "Observe the street from time to time... Note anything you can see. Anything worthy of note going on. Do you know how to see what's worthy of note?" Georges Perec, "The Street," in Species of Spaces and Other Pieces, trans. John Sturrock (London: Penguin Books, 1997, 1974), 50.
} 
closely to copy editing - a word crossed out here, a word written in thererather than hinting at another version of the events.

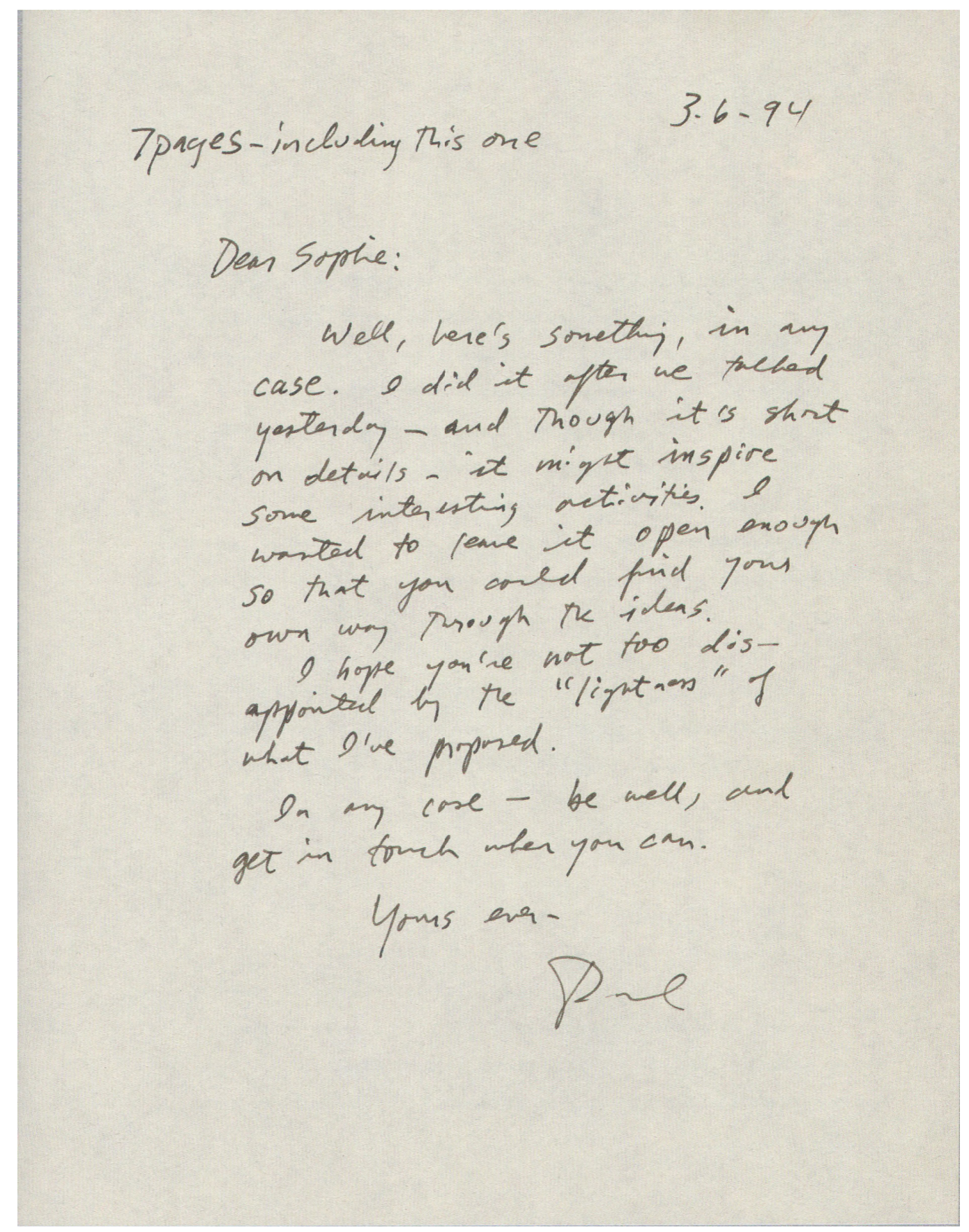

Figure 46. Paul Auster, Letter to Sophie Calle, Gotham Handbook, Double Game, 237. 
Beggars and Honeless People

I'm not asking you to reinvent the world. I just want you to pay attention to $1 t$, to think about the things around you more than you think about yourself. At least while you're outside, walking down the street on your way from here to there.

Don't Ignore the miserable ones. They are everywhere, and a person can grow so accustomed to seeing them that he begins to forget they are there. Don't forget.

I'm not asking you to give all your money to the poor. Even if you did, poverty would still exist (and have one more member among its ranks).

At the same time, it's our responsibility as human beings not to harden our hearts. Action is necessary, no matter how small or hopeless our gestures might seem to be.

Stock up on bread and cheese. Every time you leave the house, make three or four sandwiches and put them in your pocket. Every time you see a hungry person, give him a sandwich.

Stock up on cigarettes as well. Common wisdom says that ciganegiects to rettes are bad for your health, but what common wisdom segiects fo 1s that they also give great comfort to the people who smoke them. Don't just give one or two. Give ${ }^{\text {away }}$ whole packs.

If you find your pockets can't hold enough sandwiches, go to the nearest MacDonald's and buy as many meal coupons as you can afford. Give these coupons away when you're out of cheese sandwiches. You might not 11ke the food at MacDonald's, but most people do. Con-

Figure 47. Paul Auster, "Personal Instructions for S.C. on How to Improve Life in New York City (Because she asked...)," Gotham Handbook, Double Game, 241. 
Auster's directives for Calle involve a series of instructions, divided into four headings: "Smiling," "Talking to Strangers," "Beggars and Homeless People," and "Cultivating a Spot." Under "Smiling," Auster writes: "Smile when you feel angry... Smile at strangers... Smile as often as possible... Consider each smile you receive a precious gift." ${ }^{62}$ In "Talking to Strangers," Auster writes: "There will be people who talk to you after you smile at them. You must be prepared with flattering comments." ${ }^{363}$ Auster warns Calle not to ignore the "miserable ones." In "Beggars and Homeless People," he suggests Calle stock up on sandwiches and cigarettes to distribute as she walks the streets. And finally, under "Cultivating a Spot," Auster writes, "People are not the only ones neglected in New York City. Things are neglected as well." ${ }^{364}$ Thus Calle is to pick a spot in New York City and consider it hers:

Think of it as an extension of who you are, as a part of your identity. Take as much pride in it as you would your own home. Go to the spot every day at the same time. Spend an hour watching everything that happens to it, keeping track of everyone who passes by or stops or does anything there. Take notes, take photographs. Make a record of these daily observations and see if you learn anything about the people, the place, or yourself. ${ }^{365}$

This chapter considers Calle's response to Auster's instructions. Gotham Handbook presents us with an archive that clearly demonstrates and plays with its own construction, an archive that enacts the movement away from the fixity and preservation of objects associated with storage and authority, and

${ }^{362}$ Paul Auster in Sophie Calle, Gotham Handbook, Double Game, 239.

363 Ibid,

${ }^{364}$ Ibid., 241.

365 Ibid., 242. 
reconfigures the archive as a site of participation and engagement, an archive in which Calle's performance (actions carried out over time) and its documentation are not mutually exclusive, but rather interdependent.

In turning the page, we encounter a smile, presumably Calle's, which spreads across both pages of the book. Here Calle acknowledges us, the reader/viewer, who is not only a stranger, but is also an active participant (as archivist, historian etc.) in the larger project that is Double Game.

\section{The Phone Booth}

Calle chooses a telephone booth as her space/thing to take care of. It is "located on the corner of Greenwich and Harrison Streets. It's a double phone booth [of course]. I pick the right side.."366 Like all of Calle's projects, Gotham Handbook is a combination of text and photographs, and like The Chromatic Diet and Days Under the Sign of $B, C$ and $W$ it appears to document the extent to which Auster's instructions were carried out. Calle cleans the phone booth, paints the floor and parts of the booth green, adds two chairs (attached with a chain and padlock), and covers the NYNEX logo with a sign that reads "HAVE A NICE DAY." She also adds flowers, magazines, drinks, and snacks.

Calle takes the familiar corner phone booth and makes it unfamiliar by making this public space more like her "own home." Taking care of the phone booth and turning it into a more domestic space is yet another way in which Calle successfully blurs boundaries, this time between public and private. Calle's transformation of the phone booth provokes a diverse set of reactions from the neighborhood:

${ }^{366}$ Calle, Gotham Handbook, 246. 
"It's vandalism." (248)

“Maybe it's a homeless person's little place." (248)

"Another says he wouldn't want to 'mess up this set-up man.

They got everything here. It's a nice sweet home." (254)

"Is it a shrine? Did someone die here?" (258)

“' 'It's strange.'

'Good strange or bad strange?' She asks.

'Sort of in the middle,' he replies." (258)

"This is scary. Too scary!" (279)

"Why did you do this?" (279)

"This is really awesome." (279)

We understand from these responses that people are not sure how to react to the transformation of the booth. This is made more obvious in a conversation Calle transcribes:

"Why don't you use it?"

"I don't know, someone got killed here, maybe."

"Why don't you use it?"

"Nah! It's bad luck."

"Why?"

"That's what I think. It's kinda weird."367

The conversation continues, suggesting that it might be private property, maybe even organized by "drug dealers." 368

Calle's phone booth might be described as uncanny. Freud's uncanny is already rooted in notions of space, particularly domestic space; heimlich is associated with that which is homely and familiar and unheimlich with that which is strange and unfamiliar (hidden). Important to Freud's idea of the

\footnotetext{
367 Ibid., 280.

${ }^{368} \mathrm{Ibid}$.
} 
uncanny is the ways in which heimlich and unheimlich fold into each other, much like the ways autobiography and fiction converge in autofiction. ${ }^{369}$ Autofiction's reliance on undecideability is also present in Freud's concept of the uncanny: "Heimlich thus becomes increasingly ambivalent, until it finally merges with its antonym unheimlich."370

This uncertainty is also highlighted in Freud's emphasis on the uncanny's production of feeling. In speaking of E. Jentsch, who compiled a study on the uncanny titled "On the Psychology of the Uncanny" (1906), Freud writes: "For him [Jentsch] the essential condition for the emergence of a sense of the uncanny is intellectual uncertainty. One would suppose, then, that the uncanny would always be an area in which a person was unsure of his way around: the better orientated he was in the world around him, the less likely he would be to find the objects and occurrences in it uncanny." ${ }^{371}$ Calle's reluctance, and her feelings of alienation, as a Parisian woman in New York (the quintessential American city) are highlighted throughout from her disdain for the American phrase "Enjo-o-o-oy," to her continual reluctance towards her enactment of the project. The project even begins with these words: "The worst is yet to come. Tomorrow, Wednesday, September 21, I must get down to business and start smiling." 372

\footnotetext{
${ }^{369}$ It is perhaps important to note that Nicholas Royle's concept of the uncanny is closely aligned with Derridean deconstruction. Royle accentuates the ways in which the uncanny is in constant transformation and cannot be fixed. Nicholas Royle, The Uncanny (New York and London: Routledge, 2003). See also Anneleen Masschelein, The Unconcept: The Freudian Uncanny in Late-Twentieth Century Theory (Albany: State University of New York, 2011).

${ }^{370}$ Sigmund Freud, "The Uncanny," in The Uncanny, trans. David Mclintock (London, New York: Penguin Editions, 2003 (1919)), 134.

${ }^{371}$ lbid., 125.

${ }^{372}$ Calle, Gotham Handbook, 246.
} 
In his essay on the uncanny, Freud also stresses the importance of the double (doppelgänger):

in all its nuances and manifestations-that is to say, the appearance of persons who have to be regarded as identical because they look alike...

$[\ldots]$

Moreover, a person may identify himself with another and so become unsure of his true self or he may substitute the other's self for his own. The self may be thus duplicated, divided and interchanged. ${ }^{373}$

Calle's continued use of the double is not only realized through her interplay with Auster's novel—Maria's adoption of her projects and Calle's adoption of Maria's projects—but also through an obsession with shadowing and following, and her frequent use of another as a stand in for herself, and vice versa. In Gotham Handbook Calle is replaced by a friend, D, on Sunday, who refuses to record the telephone conversations (which Calle does), but transcribes and photographs the comings and goings, and distributes smiles, food, and cigarettes as per Auster's instructions. All of these strategies of displacement and substitution reinforce the importance of doubling in Double Game as a way to dislocate the singularity of the self and the events experienced, and to challenge the unification of she who narrates and she who is the subject of her enunciations. According to Evija Trofimova, the double in postmodern literature has become multiple, opening up the doppelgänger to rhizomatic structures. ${ }^{374}$ Calle's archival strategies mimic this rhizomatic structure: her projects in Double Game, her other projects, her collaborations with other artists and authors, her

\footnotetext{
${ }^{373}$ Freud, "The Uncanny," 141-142.

${ }^{374}$ Evija Trofimova, "Double and Disappearances," in Paul Auster's Writing Machine (New York and London: Bloomsbury, 2014), 109.
} 
fictional appearance in Auster's novel, her appearance in Grégoire Bouillier's novel, etc., and all work towards building a relational network in which "Calle" is continually "duplicated, divided and interchanged."

\section{New York City/Gotham City}

The premise for Gotham Handbook is that Paul Auster, in keeping with Auster's and Calle's "mingling of fiction with fact," is to create a "fictive character" which Calle would "attempt to resemble." However, Auster has created a series of instructions that are less playful than monochromatic meals and days spent under specific letters of the alphabet. In Auster's project, the everyday and the ordinary are highlighted as Calle must interact with, and observe, the inhabitants of New York City. His title, Gotham Handbook, however, references the fictional world of New York City, as represented in comic books published by DC Comics. Auster's fiction is thus an imitation of life as art as life as art... flattening the difference between art and life.

However, Calle's writing emphasizes the "reality" of her situation by continually expressing her feelings of alienation in New York and by stressing the American-ness of the city: "I cover the telephone company's logo... with a sign that reads: HAVE A NICE DAY, the American expression which punctuates every conversation and which I hate the most after 'Enjoy!' (But I couldn't bring myself to use that. Imagine, putting pleasure in the imperative like that! ....." ${ }^{375}$ But she does exactly this on the following day: "During the night I pay it [the booth] a visit. I also take the opportunity to paste the word 'ENJOY' in black

\footnotetext{
${ }^{375}$ Calle, Gotham Handbook, 246. Gotham Handbook was originally created in English only and
} was then translated into French for Doubles jeux (the original boxed set of Calle's projects). 
letters on the right side of the booth." ${ }^{376}$ In Double Game, this description is accompanied by a photograph of the phone booth, showing the letters "E-N-JO-Y" pasted down the right side of the booth (figure 48). Humour is present in much of Calle's work, often as a kind of parody of the genre she imitates, and her pasting of ENJOY in a situation she is clearly not enjoying can be read as a kind of ironic jest. ${ }^{377}$

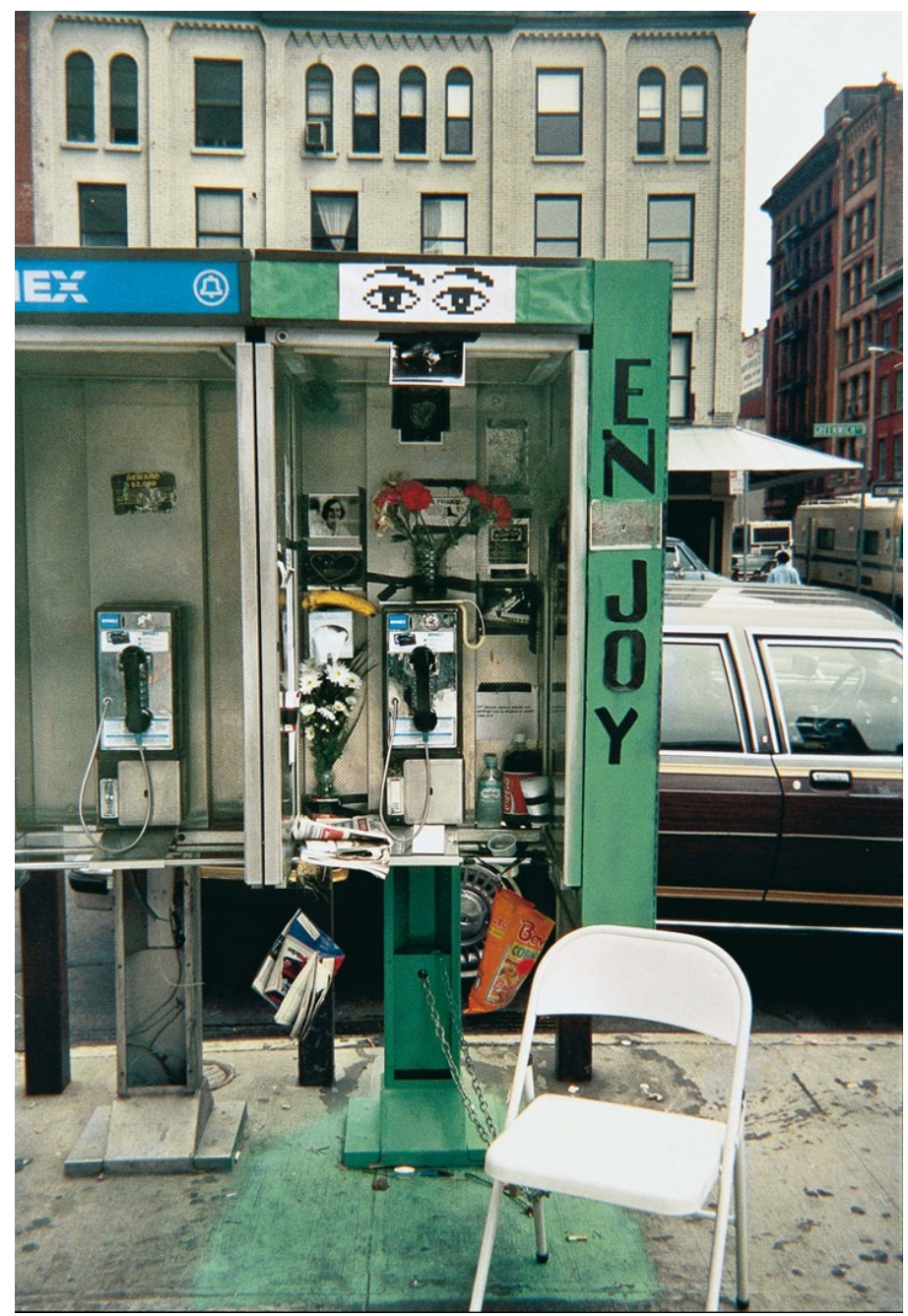

Figure 48. Calle, Gotham Handbook, Double Game, 247.

\footnotetext{
376 Ibid., 252.

${ }^{377}$ Luc Sante describes Calle's work as a "parody of a parody, a simulacrum of a sham." Sante, Sophie Calle's Uncertainty Principle," 74.
} 
On day two Calle sets off for a "spy store" only to find out that "bugging" a phone carries a hefty penalty: "Two years of prison for wiretapping a public phone, they said. I have a fantasy: I am arrested, I stand before the judge. He proposes an alternative punishment: smile, distribute food, and talk to people, I say: 'No! I prefer jail!"”378 When Calle finally receives a smile, she jests, "He smiles at me. He stops to talk with me about the weather: 'Hello lady, beautiful day!' Maybe another disciple of Paul's Gotham Handbook. I smile back."379

Auster's "Personal Instructions for S.C...." dictate a series of actions that Calle must perform. Auster writes: "Action is necessary, no matter how small or how hopeless our gestures might seem to be." ${ }^{380} \mathrm{He}$ also stresses how these gestures - these small actions—like talking about the weather, which "affects us all in the same way," is a "sign of good will, an acknowledgement of your common humanity with a person you are talking to."381

\section{Sexual Difference}

Yet, despite the rhetoric of "common humanity," Auster already acknowledges sexual difference: "New York can be dangerous, so you must be careful. If you prefer, smile only at female strangers. (Men are beasts, and they must not be given the wrong idea.) ${ }^{\prime 382}$ Calle seems to reiterate this throughout her daily account. On the first day she notes: "During the night of Tuesday, September 20, 1994, I take over the phone booth. I start by dusting and polishing. Two men are watching me. One of them asks, 'Do you do windows too?' Am I supposed

${ }^{378}$ Calle, Gotham Handbook, 252.

379 lbid., 251.

${ }^{380}$ Auster in Calle, Gotham Handbook, 241.

${ }^{381}$ Ibid., 240.

382 Ibid., 239. 
to inaugurate my smiling task? I choose to postpone it until tomorrow, I don't answer, for as you said yourself Paul, men are pigs." 383 On Thursday, September 22, Calle writes: "One of the pigs approaches me and asks if his friend can take a photo of us together. I agree and smile. It's part of the deal." ${ }^{384}$ The facing page contains twelve small photographs of people walking by and/or stopping to use the phone booth (figure 49). ${ }^{385}$ In the final image, we recognize Calle, she is sitting on the lap of a man, smiling.

\footnotetext{
${ }^{383}$ Calle, Gotham Handbook, 246.

384 Ibid., 254.

${ }^{385}$ Ibid., 255.
} 

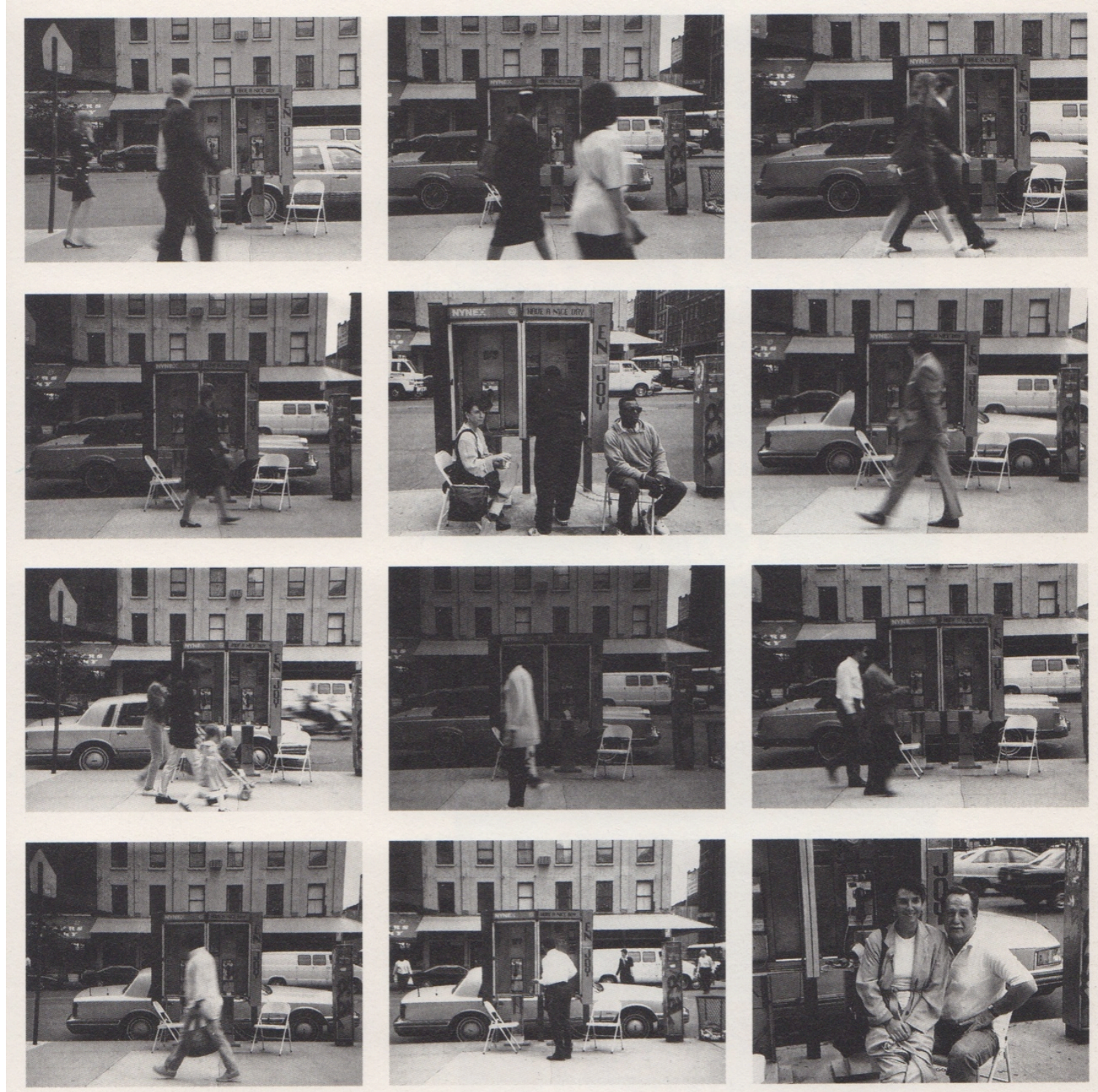

Figure 49. Calle, Gotham Handbook, Double Game 255.

Unlike The Striptease, and her following projects in which distance is shown to be part of the operations of spectatorial desire, here in Gotham Handbook Calle must interact, and offer "flattering comments." The text accentuates her uneasiness with the project, and she is an unenthusiastic participant, even having a friend take her place on one of the days. We note 
Calle's insistence that this project is an act of "obedience": "I have a duty to obey. That was the agreement. I have no other choice but to submit.." ${ }^{386}$ And: "As a demonstration of my capacity to perform obediently these good deeds that I am asked to do, I cover the telephone company's NYNEX logo, the name of which is displayed...." ${ }^{387}$ But Calle is not always obedient to Auster's instructions. On Monday, September 26, she writes, "I remember Paul's words, 'Try to keep these conversations going as long as you can,' but they have no effect on me. I decide to disobey: I cut him [the stranger] off and leave."388 Calle's authorial games with Auster are emphasized in this project in which Auster authors Calle's actions, as she becomes a "fictive character." The space between Calle the author/artist and Calle the subject of Auster's writing is enhanced through her resistance to performing the actions demanded of her. Yet, as in The Chromatic Diet, Calle also adds her own initiatives: "Paul didn't ask me to count the smiles I give. Unquestionably an oversight. I add this item to the Handbook." ${ }^{389}$

\section{As Information}

From Wednesday, September 21, 1994, to Tuesday, September 27, 1994, Calle, according to Auster's instructions, takes photographs and makes notes of her interactions. The photographs, both black and white as well as colour, provide a range of images: the phone booth in various stages of transition and transformation; the people who use or pass by the phone booth; the food Calle

\footnotetext{
386 Ibid., 246.

387 Ibid.

388 Ibid., 285.

389 Ibid., 246.
} 
makes to distribute; the cigarette packages she buys to hand out; and some close up images of details of the phone booth, including photographs of a sheet of paper she leaves there daily for "comments, suggestions and complaints." Calle is occasionally present in the photos.

Each day, her notes are divided into two sections. The first section centres on the activities of the phone booth by noting the comments made on the comment sheet, providing transcripts of the conversations she records of the people who use the phone, as well as the conversations she overhears as people pass by. The second section reflects the making of the food and her interaction with people on the street as she distributes the food, cigarettes, and smiles. She even "buys two counters to keep track of the smiles given and smiles received." ${ }^{390}$ Each entry for the day concludes with a tally reflecting the number of "smiles given (and received)," "sandwiches accepted (and refused)," "packs of cigarettes accepted (and refused)," and total amounts, in minutes, of conversations had. Auster's project is thus reduced to statistics, emblematic of bureaucratic record keeping. The entire project is brought to an early conclusion by the telephone company who remove all her adornments, and finishes with this concluding tally:

Results of Operation:

125 smiles given for 72 received

22 sandwiches accepted, 10 refused

8 packs of cigarettes accepted for 0 refused

154 minutes of conversation. ${ }^{391}$

\footnotetext{
390 Ibid., 251.

391 Ibid., 293.
} 
As I have argued in Chapter Two, much of Calle's work is based on collecting, gathering, and producing information, and her work plays with how that information is recorded and represented. Calle's gathering and organizing of information has led critics like Suzanne Küchler and Michael Morely to position Calle as a "self-styled ethnographer of the everyday." 392 Like ethnography, her work is based on processes of "hyper-detailed observation and data gathering, using complex strategies of surveillance, reportage and documentation." ${ }^{393}$ Küchler, however, also acknowledges that Calle subverts ethnographic processes by including her own subjective and affective comments. This inclusion of subjective notes challenges the role of the observer and plays with our concept of objectivity. As Auster encourages: "Make a record of these daily observations and see if you learn anything about the people, the place, or yourself. ${ }^{394}$ Küchler suggests that Calle, like the ethnographer, aims to "uncover" the social relations between objects, people, and spaces through "ethnographic participant observation. ${ }^{395}$ Yet Calle participates, and provokes participation from others, in situations and rituals that are carefully constructed, artificial, and often staged. And as we have seen, she frequently fabricates her information and documents. Johnnie Gratton has

\footnotetext{
392 Suzanne Küchler, "The Art of Ethnography: The Case of Sophie Calle," reprinted in Sophie Calle: The Reader (London: The Whitechapel Gallery, 2009), 93; and David Morely, Media, Modernity and Technology: The Geography of the New (London and New York: Routledge, 2007), 100. Morely repeats many of the arguments (sometimes word for word) from the early article written by Suzanne Küchler. While I reference Küchler's article, it does get some of its details wrong. For example, Auster and Calle did not "enter into a creative partnership in the 1970s," but much later (92). Also, Kuchler talks about Gotham Handbook as living out the character of Maria, when this project was written explicitly for Calle (93).

${ }^{393}$ David Morley, Media, Modernity and Technology: The Geography of the New, 100.

${ }^{394}$ Auster in Calle, Gotham Handbook, 242.

395 Suzanne Küchler, "The Art of Ethnography: The Case of Sophie Calle," 93. Küchler focuses on Calle's The Birthday Ceremony drawing in a discussion of Marcel Mauss, Essai sur le don (1924).
} 
referred to her projects not as ethnographies but as "experiments: experiments run not with a view to testing any particular hypothesis, but far less teleological, in order to 'see what happens'. ${ }^{396}$ Gratton stresses her double focus: photography ("to see") and narrative ("what happens") and describes Calle's experiences as "experimental experience."397

What are produced in Calle's projects are remnants and documents of these transactions and interactions. In his book The Big Archive: Art from Bureaucracy, Sven Spieker quotes a passage from Johann Gustav Droysen's Historik, which states that contained within archives, all documents, records, letters, etc., are "remnants" of "various transactions."398 Gotham Handbook thus presents us with a variety of documents of Calle's transactions and interactions. Calle builds her archive from a variety of visual and discursive material, from her interaction with Auster to her daily interactions with the people at the corner of Greenwich and Harrison Streets. Gotham Handbook plays with our understanding of an archive as an authoritative, regulatory, and bureaucratic space, by transforming it into a ludic space for interaction and participation.

\section{The List/Archive}

As in Calle's other projects, throughout Gotham Handbook, the list becomes the main form for relaying daily information and observations: we have transcripts of the recorded conversations; a list of the suggestions written daily on a sheet;

\footnotetext{
${ }^{396}$ Gratton, "Experiment and Experience in the Phototextual Projects of Sophie Calle," 158. 397 Ibid.

398 Johann Gustav Droysen's "Historik," quoted in Spieker, The Big Archive: Art from Bureaucracy, 254.
} 
a list of what is missing from the phone booth every day; and finally Calle completes each day with a tally of her (trans)actions.

In Calle's initial written response to Auster she also employs a number of lists, such as a list of all the possible compliments she could use when talking to strangers: "It was lovely to have a chat with you, I hope l'll have the pleasure again. This was a very interesting conversation, we must get together again. What a terrific hairdo. I really do like that." ${ }^{399}$ She lists "meteorological" vocabulary, so she can follow Auster's repeated tip: "if you can't think of anything to say, begin by talking about the weather": "breezes, storms, turbulence, fog, squalls, sunny spells, slight improvements... you can be baking, roasting, freezing, melting... the temperature can be mild, clement, idyllic, freezing, frosty, harsh, Siberian...." ${ }^{400}$ The infinity of lists, as articulated by Umberto Eco, which I discuss in Chapter Three is hinted at as Calle's exhaustive list of weather words threatens to take over the text. Calle ends with this comment: "Paul is right, you could go on about it [the weather] forever. And if I crack up, why not: 'I hate this stupid sun. It's really a day for hanging yourself, don't you think?" ${ }^{401}$ We are given a list of everything she bought to decorate the spot: "I buy: Glass Plus window cleaner, Brasso metal polish, Krylon "clover green" spray paint, six writing pads, six pencils, a mirror, Devcon epoxy glue, two twelve-foot chains, two padlocks, a bouquet of red roses, one ashtray, two folding chairs, and the current issue of Glamour magazine." ${ }^{\text {"402 }}$ She

${ }^{399}$ Calle, Gotham Handbook, 246.

400 lbid.

401 Ibid.

402 Ibid. 
even notes her grocery list: "I buy white bread, sliced yellow cheese, ham, tomatoes and four packs of cigarettes." ${ }^{303}$

According to Robert E. Belknap, the list becomes not only a way to organize ("enumerate, account, remind, memorialize, order"), but present the information pertinent to the project for us to interpret. Lists offer personal constructions that invite different interpretations and generate endless connections: "The value of the lists is that they ask us to make them meaningful." ${ }^{\text {404 }}$

\section{Performative Photography}

Calle's use of the list also highlights the repetitive nature of her daily actions. Each day replicates the actions from the day before, but each day the results are different. This emphasis on repetition is also seen in her photographs. We see the same objects photographed daily: the activities around the phone booth, the food she makes, as well as the comment sheet. These images help draw attention to the reiterative nature of Calle's daily enactment of Auster's instructions.

In her book, Words to be Looked At, Elizabeth Kotz argues that conceptual projects of the 1960s not only began to combine words and images, but also often proposed a set of "procedures" or instructions as a way to produce work:

Unlike the photographic logic of original and copy, the relation between a notational system and a realization is not one of representation or reproduction but of specification: the template, the schema, or score is usually not considered the

\footnotetext{
403 lbid.

${ }^{404}$ Belknap, "Preface," The List: The Uses and Pleasures of Cataloguing, XV.
} 
locus of the work, but merely the tool to produce it; and while the work must conform to certain specifications or configurations, its production necessarily differs from realization to realization. ${ }^{405}$

The relational and illimitable possibilities generated by the instruction are reinforced by Calle's account of her daily actions, her use of the list, and her daily observations. Kotz proposes that by engaging photography as a notational system conceptual works dislocate photography from the reproductive logic of original and copy to reposition it as a recording mechanism for specific realizations of general schemata. ${ }^{406}$ She writes: "This performative mode returns with a difference-no longer the unique live performance, it reemerges as marked by the properties of reproductive media, as structurally subject to inscription, iteration and repetition." ${ }^{407}$

In an essay on Edward Rusha's photographs, Margaret Iversen also discusses the performative possibilities offered by the instruction. Iversen's understanding of the performative is slightly different from Phillip Auslander's performativity of performance documentation, and separate from Gade and Jerslev's performative realism. Iversen argues that: "Performative photography begins with an instruction or rule which is followed through with a performance." ${ }^{408}$ For Iversen, performativity signals that the present gesture is always an iteration or repetition of preceding acts. Gotham Handbook puts into

\footnotetext{
${ }^{405}$ Liz Kotz, Words to be Looked At: Language in 1960s Art (Cambridge, Massachusetts: The MIT Press, 2010), 194.

${ }^{406}$ Ibid.

407 Ibid., 212.

${ }^{408}$ Margaret Iversen, "Auto-maticity: Ruscha and Performative Photography," in Photography after Conceptual Art, eds. Diarmuid Costello and Margaret Iversen (United Kingdom: Blackwell Publishing, 2010), 15.
} 
"play repetition and the inherently iterative character of the instruction." According to Iversen, the instruction points to the reiterative nature of speech and action, like Austin's performative speech act, the instruction makes something happen. ${ }^{410}$ Calle's adherence to Auster's instructions thereby accentuates the performative quality of her photographs.

Iversen also maintains that: "Performative photography involves the partial abdication of authorial control, in favour of accident, chance or unforeseen circumstances." ${ }^{411}$ Gotham Handbook operates at this junction between scripted actions and the possibility for chance encounters. The photographs of the phone booth accentuate the chance encounter by presenting seemingly "amateur" photographs; they are not very interesting in their framing, and the passers-by are often out of focus. As in The Striptease, they are taken from a variety of angles and distance, suggesting the movement of the photographer in the scene we are witnessing.

In an essay on two Danish photobooks from the 1970s, Mette Sandbye suggests that "Common to both the documentary and conceptual expressions in the early 1970s (as well as amateur praxis) is the withdrawal of an overt authorial interpretation, a lack of interest in formal aspects of the medium, a focus on letting the subject-matter speak for itself, a focus on certain aspects of

\footnotetext{
409 lbid.

${ }^{410}$ Ibid.

411 Ibid.
} 
vernacular culture and on photography as a social practice, linking it to the reallife-world, rather than an expressive, graphic medium." ${ }^{412}$

But as Spieker points out, "nothing enters the archive that is not in some sense destined to be there from its inception." ${ }^{413}$ Structures for archiving, documenting, and collecting information are always embedded in Calle's rituals and games. In Gotham Handbook, the camera, the recording device for the phone, her notebook, the counter to tally the smiles, the comment sheet make obvious the manner in which Calle's production of her archive is bound to the structures and forms set up to collect information. The concept of the archive and what it contains emerge together. Gotham Handbook thus demonstrates the ways in which "the past we come to inspect in an archive is fully contingent on the conditions (and constraints) of the process of archivization itself, and that to take note of this is to acknowledge the difference between historiography and fiction. ${ }^{314}$ But, as we know by now, Calle's work also challenges this distinction.

\section{Temporal Unfolding}

In one of Calle's earlier works, Les dormeurs (1979), not included in Double Game, she invited people to sleep in her bed, to literally come to her house and take her place each night (as yet another kind of substitution) while she interviewed them and photographed them sleeping. The full title of this project is Provocation de situations arbitraires qui prennent la forme d'un rituel: les dormeurs. Her project, dictated by her own constraints, consists of a series of

\footnotetext{
${ }^{412}$ Mette Sandbye, "Performing the Everyday: Two Danish Photos Books from the 1970s," in Performative Realism: Interdisciplinary Studies in Art and Media, eds. Rune Gade and Anne Jerslev (Denmark: Museum Tusculanum Press, University of Copenhagen, 2005), 22.

${ }^{413}$ Spieker, The Big Archive: Art from Bureaucracy, 173-174.

${ }^{414}$ Ibid., 26.
} 
photographs of various people sleeping in her bed. The photographs are taken over the duration of the participants' sleep, with times noted, accompanied by descriptions of each individual. This project, its title specifically, emphasizes how Calle's work exploits this movement between the chance encounter and the arbitrary, and the collection of information and cataloguing associated with bureaucratic archives. According to Spieker, traditional archives were seen as recordings of past events that were "in synch with the process of these events unfolding. ${ }^{415}$ Les dormeurs replicates this unfolding of the events in a linear manner; one photograph follows another arranged by their temporal unfolding. When exhibited, Les dormeurs also offers a consistency in the arrangement of the photographs; all the photographs are the same size, laid out in a grid formation (figure 50).

${ }^{415}$ Spieker, The Big Archive: Art from Bureaucracy, 27. 


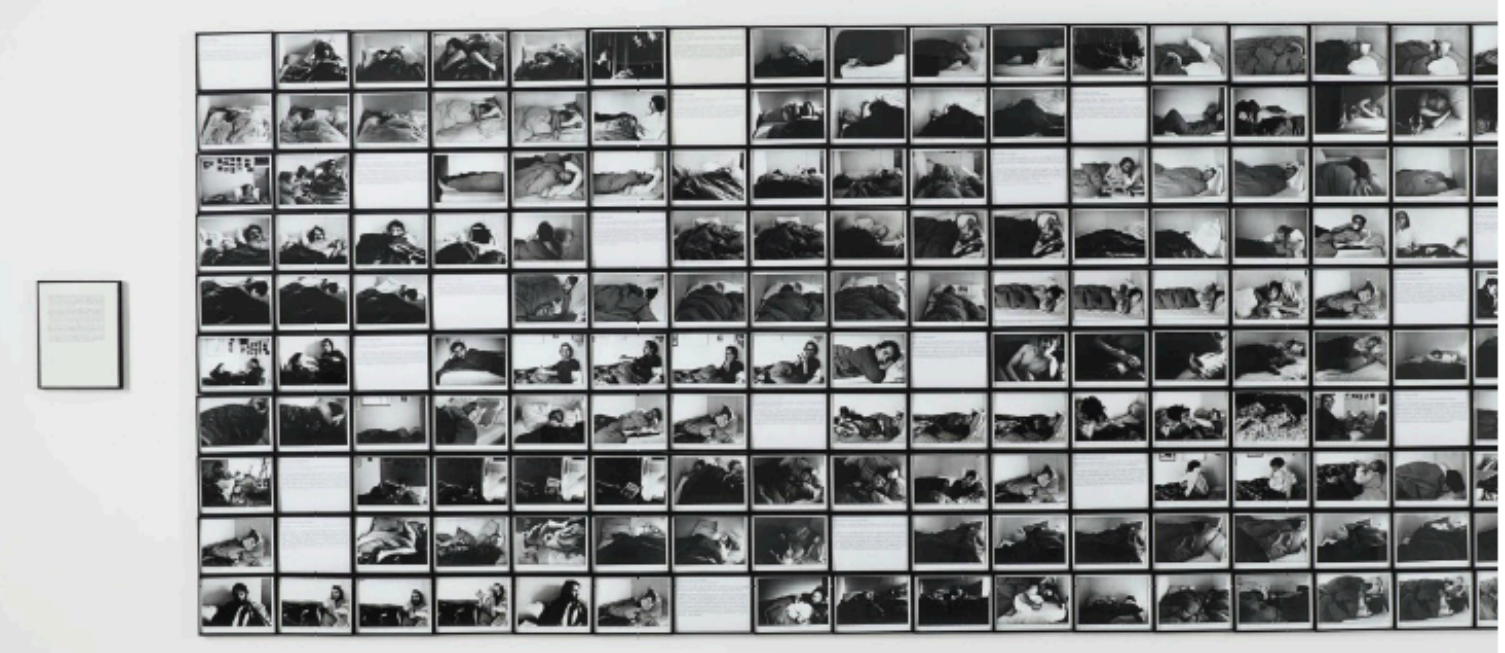

Figure 50. Sophie Calle, Les dormeurs, 1979.

Source: Christie's The Art People

http://www.christies.com/lotfinder/photographs/sophie-calle-the-sleepers-

5496990-details.aspx (accessed Nov. 27, 2014).

In contrast, Gotham Handbook shows a series of photographs ranging from full-page images to smaller photographs of varying sizes. Occasionally we see the same person in a few shots, suggesting their conversation unfolding over time. On the first day, Wednesday, September 21, 1994, the text reads: "10pm: Visitor \#1, in his fifties, wearing a grey suit, tries to make a call from the left booth. It doesn't work. He grabs my phone, but something must be bothering him because his body is still stationed in the left-hand booth. I feel rejected. I decided to force him to move by pretending that I need the left-hand phone. He resists." ${ }^{416}$

In two of the six corresponding photographs on the facing page, we can identify a man in a gray suit standing on the left side of the phone booth while

${ }^{416}$ Calle, Gotham Handbook, 248. 
using the phone from the right; and in a third photograph we see a woman next to the man, using the left phone booth, thus forcing him into the space of the right phone booth. The photographs seemingly authenticate the events as described in the text.

However there are a number of inconsistencies between the photographs and the text. First the photographs are taken during the day, rather than at $10 \mathrm{pm}$, as the notes suggest. This is made evident because the last two of the six photographs are taken at night (figure 51). If the woman that appears is Calle, which it could be, then who is taking the photographs? The times in the diaristic account are: $12 \mathrm{pm}, 10 \mathrm{pm}, 12: 25 \mathrm{pm}$ and $1 \mathrm{pm}$. This is not logical and confuses our understanding of the succession of events. In the last two photographs we see the ENJOY sign that she installs, supposedly later that same night (and on the next page in her description of events). The photographs do not represent the events in sequential order, instead they gesture towards the events that took place out of synch. The photographs fail to authenticate the temporality of the events described. As I have outlined, autofiction also employs temporal instability, assembling events in a "radically altered presentation, disorderly, or in an order, which deconstructs and reconstructs narrative according to its own logic. ${ }^{\text {"17 }}$ Calle's temporal play challenges the perceived stability and bureaucratic order once associated with the archive.

${ }^{417}$ Doubrovsky, "Autofiction," 1. 

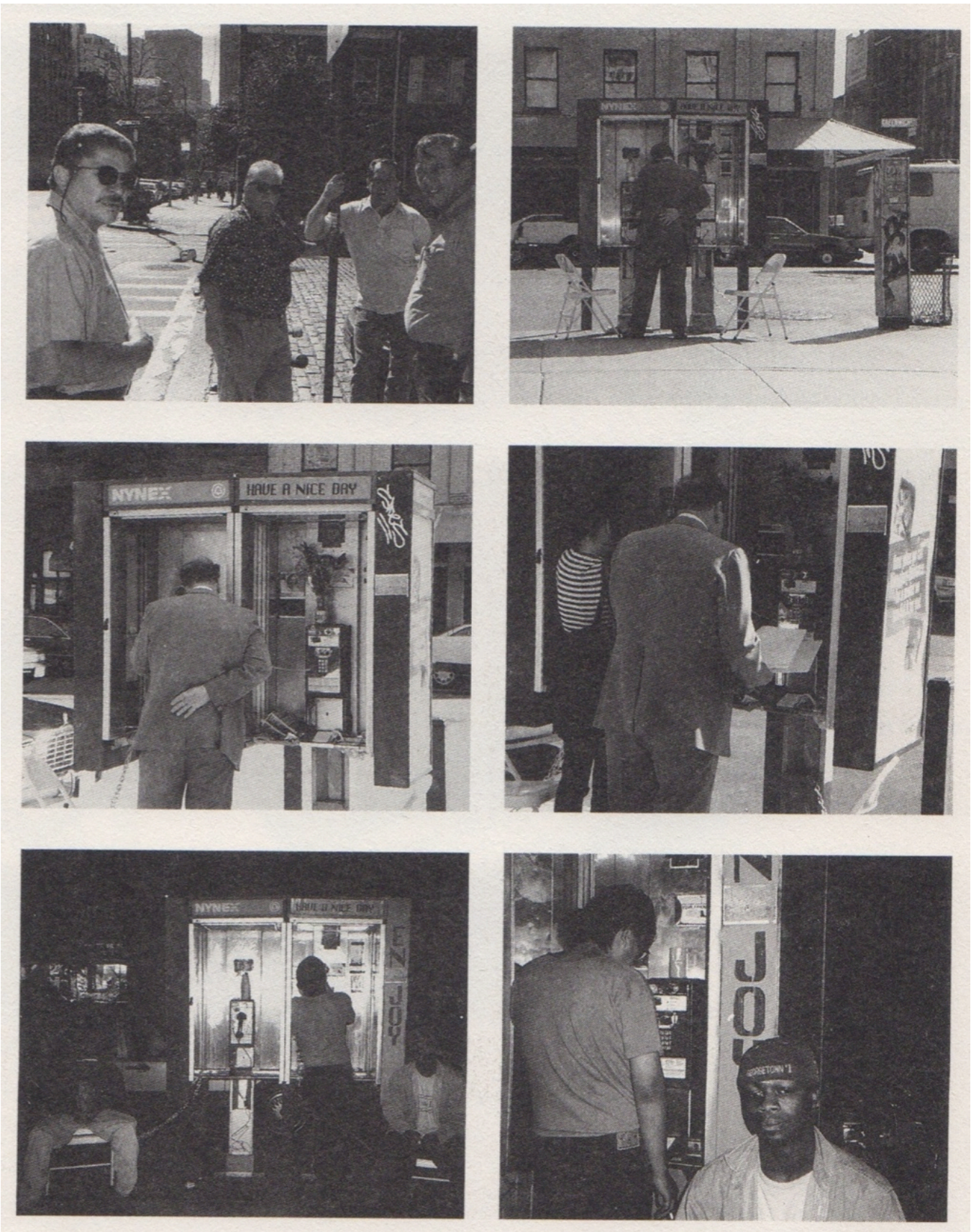

Figure 51. Calle, Gotham Handbook, Double Game, 249.

Calle's photographs of the street are balanced with her photographs of plates of food taken against a white background. The photographs of the food are reminiscent of the photographs of the plates of food in The Chromatic Diet; 
only in Gotham Handbook these plates are not so aesthetically appealing; these do not conform to the artifice described by Barthes regarding the photographs of food in Elle magazine. This is the food of everyday existence, ham and cheese sandwiches, ham and tomato, the food of necessity, real food to be consumed (figure 52).

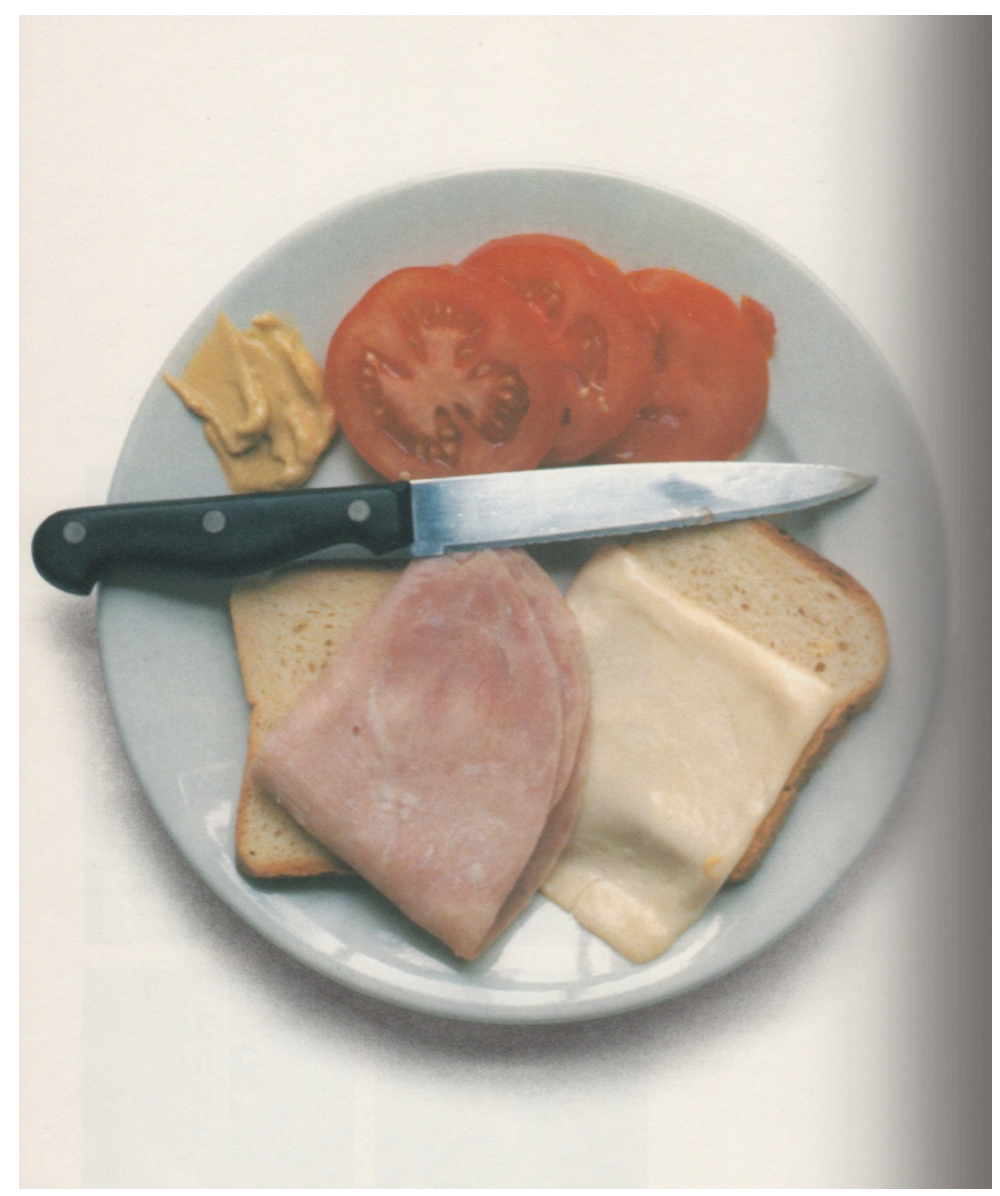

Figure 52. Calle, Gotham Handbook, Double Game, 250.

These photographs hover between the past and the future, they are both anticipatory (awaiting Calle's interactions on the street) and historic (as trace of events passed). These images also serve to furnish the archive with "proof" of the food made and seemingly attest to Calle's commitment to Auster's 
instructions. These photographs, as documents that indicate both the beforethe-event and the after-the-event, draw attention once again to the lack of documentation of Calle's physical interactions. Calle is not completely erased as we see Calle in a few of the photographs. However, as viewer, we fill in the space of the event through the images provided. As Amelia Jones has argued, the event is retrospectively formed by its documentation. ${ }^{418}$ Calle's text, her narration of the events, happens in the future, after the event has come to pass. Calle thus performs a kind of historiography by transforming her own archival residue into a narrative. ${ }^{419}$ Calle's cataloguing and organizing of her experience becomes a way of showing and telling that disrupts archival logic by provoking a rethinking of the relationship of the archive to the event and to historiography which we can conceive of as a series of possible encounters that occur in and within the archive. This movement and overlap between the production of archival records and traces, and narration is similar to Marco Codebò's understanding of the archival novel, which "weaves" the creation and verification of records "into the fabric of its text, thus functioning as a record all the while narrating the unfolding of its own archivization." 420

\section{Archiving the Ordinary}

Calle's archive demonstrates, as Terry Cook has argued, that an archive is no longer perceived of as a space for preservation- "passive storehouses of old

\footnotetext{
${ }^{418}$ See Amelia Jones, "'Presence' in Absentia: Experiencing Performance as Documentation," Art Journal 56, 4 (Winter 1997): 11-18.

${ }^{419}$ This is in accordance with Wolfgang Ernst understanding of historiography, which he defines as "the transformation of the archive's space into the effect of a [temporal narrative]." Wolfgang Ernst quoted in Spieker, The Big Archive: Art from Bureaucracy, 27.

${ }^{420}$ Codebó. Narrating from the Archive: Novels, Records and Bureaucrats in the Modern Age, 25.
} 
stuff $^{\prime 421}$ — but rather offers a new paradigm in which archives are already

understood to be "dynamic" and "active" agents, away from "seeing the context of records creation resting within stable hierarchical organizations to situating records within fluid horizontal networks of work-flow functionality." ${ }^{422}$ Gotham Handbook foregrounds this rhizomatic structure of the archive by replicating a variety of conversations heard, conversations recorded, stories from the various people Calle gives sandwiches, cigarettes and smiles to, as well as the discordant voices written on the comment sheet.

On Saturday, September 24, the comment sheet reads:

Missing brush, comb, lipstick, and cologne

Leave some quarters

I think it's cool

Està muychévere Fedex

It's great, Love it-Maria M

Fabulous concept

Great scheme

Great, except cigarettes kill-Stone

I think whoever did this is a fucking dick-head and probably

has no job.

Get a life you stupid bitch. DAVE

Dave is an asshole

Cool Man I like this a lot keep it up - Love, Jaz

Who the fuck put this faggot bullshit here?

More cigs

I love it

Who would eat this? $?^{423}$

Calle's repetition of the comments in the text and her replication of the comment sheet as a photograph are reminiscent of The Birthday Ceremony and Days Under The Sign of $B, C$ and $W$ in which the photographs and the list reinforce

\footnotetext{
${ }^{421}$ Terry Cook and Joan M. Schwartz, "Archives, Records, and Power: From (Postmodern) Theory to (Archival) Performance," Archival Science 2 (2002): 172.

${ }_{422}$ Cook, "Archival Science and Postmodernism: New Formulations for Old Concepts," 4.

${ }^{423}$ Calle, Gotham Handbook, 264.
} 
each other (figure 53). The photograph authenticates the diversity of the list because we can identify different handwriting which helps cement the seeming authenticity of her archive: the discordant voices of the inhabitants of New York City as they interact with her phone booth. However, Calle's archival documents are no longer file cards and reports—paperwork associated with bureaucratic and official archives—but rather crumpled bits of paper on which hand-written notes are scribbled and collected at the street corner. 


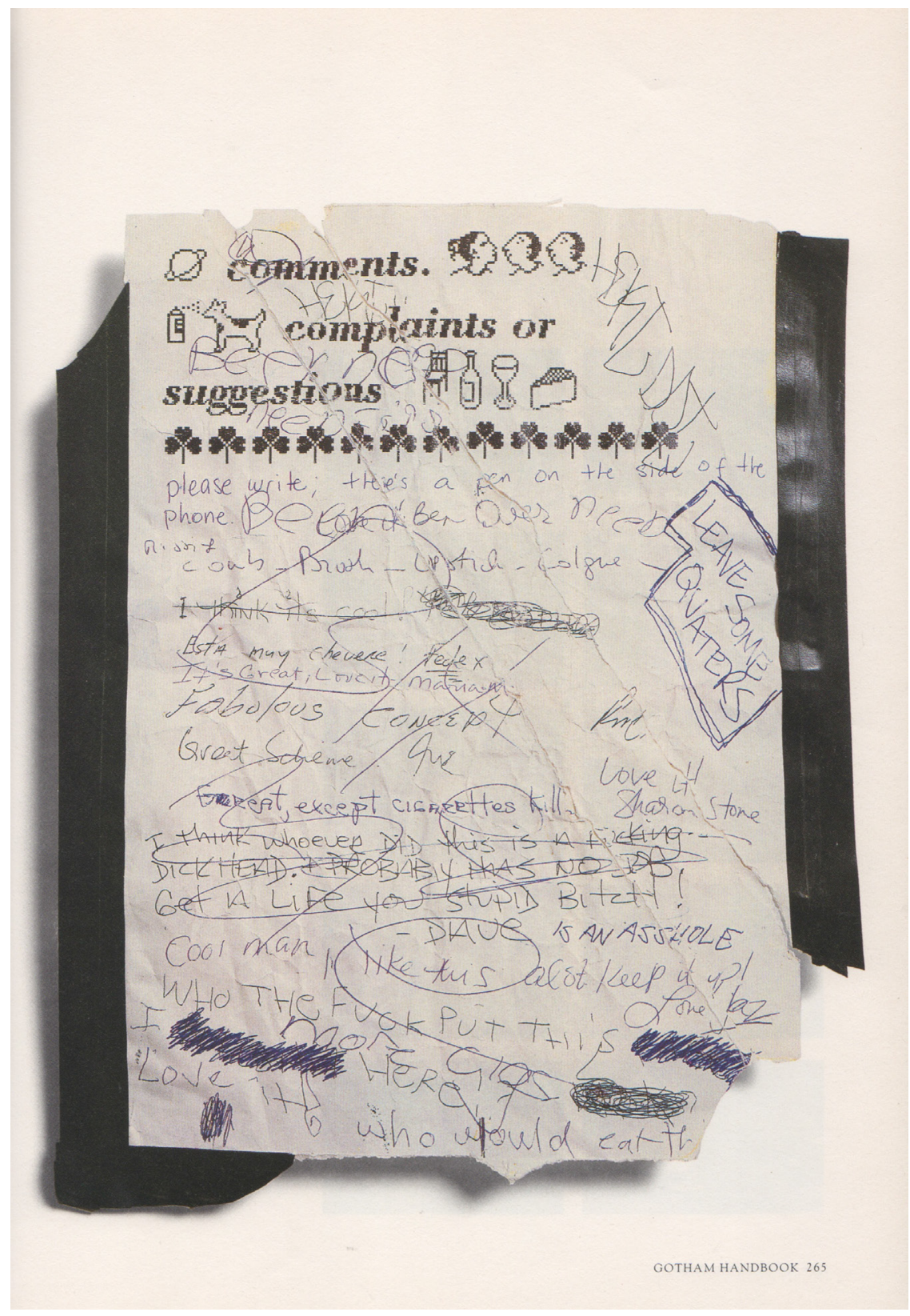

Figure 53. Calle, Gotham Handbook, Double Game, 265.

Calle's project comes to an early close due to "an act of vandalism" which was "perpetrated by the telephone company." ${ }^{224}$ On the following page, there are two photographs, which take up a little over half the page. The

${ }^{424}$ Calle, Gotham Handbook, 286. A funny reversal, since it is Calle who has actually vandalized the phone company's property. 
photograph on the right hand side shows a telephone booth with a printed sign taped to the top:

We are sorry to inform you that we will no longer be able to continue serving you as we have. On Tuesday 27 of September at 9:30 A.M. some AT\&T agents put an end to it all by threatening us and throwing the arrangement (flowers, newspaper, magazine, pen and paper, drinks, cigarettes, etc.) in the garbage. We thank you so much for having used our services and for the generosity of your comments. Goodbye. ${ }^{425}$

The text is also reprinted in large font across the bottom of the two pages. The second photograph shows a garbage can, with the described contents. It is difficult to make out each object due to the low contrast of the image, but we can easily see a Camel cigarette pack and a crumpled comment sheet.

At the beginning of his book, Sven Spieker describes llya Kabakov's Sixteen Ropes (1984): "numerous pieces of garbage dangle at regular intervals, roughly at eye level, from sixteen parallel ropes that are suspended a meter and a half from each other and the same distance from the floor." ${ }^{426}$ Reading Kabakov's work as an archive, Spieker claims: "Archives contain paperwork that no longer circulates in the bureaucracy, paperwork that has lapsed and becomes garbage. ${ }^{427}$ Like Kabakov's Sixteen Ropes, I suggest that Calle's archive also aims to transform the seemingly insignificant—bits of paper, snippets of conversations-into "documents of culture and history." ${ }^{\text {"28 }}$ The relationship of scribbled pages to garbage is made more obvious by this photograph of the comment sheet crumpled in the bin.

\footnotetext{
${ }^{425}$ Calle, Gotham Handbook, 289.

${ }^{426}$ Spieker, The Big Archive: Art from Bureaucracy, ix.

${ }^{427}$ Ibid.

${ }^{428}$ Ibid., X.
} 
What emerges through reading and viewing Gotham Handbook is the transformation of Auster's instructions into action, and interaction-as embodied, durational, and inter-subjective. ${ }^{429}$ In turn these acts are transformed into a series of photographic documents, records, lists, and personal narratives. Gotham Handbook offers an archive, even if it carries a tinge of parody, that foregrounds the means by which archives are produced, stored and made meaningful as documents of actions and transactions, but not the transactions themselves. Calle's archive draws attention to what archives do not usually hold, the everyday, the ordinary: everyday interactions that usually disappear without a trace.

Gotham Handbook skillfully maneuvers between what François Lyotard has described as the difference between domus, as a collection linked to home and lived life, and the arkheion, as official residences (offices, agencies) where the "transmission of culture has become a matter not of narrative but of lists." 430 In contrast to the arkheion, the domus is the space of narrative: "narratives are like gestures, related to gestures, places, proper names." ${ }^{431}$ The city, Lyotard contends, is where "stories, the generations, the locality, the seasons, wisdom and madness..." are subject to cataloguing, inventory, and administration by letters and numbers. Calle's phonebooth and its interplay between public and domestic space, home and not home, help draw out some of these tensions.

\footnotetext{
${ }^{429}$ Engaging Merleau-Ponty's ideas from his 1945 Phenomenology of Perception, Amelia Jones has convincingly argued that performance, body art specifically, "interprets and produces the self as embodied, performative and intersubjective," and can be read as a critique of the Cartesian subject. Jones, "Postmodern, Subjectivity and Body Art," 39-40.

${ }^{430}$ Francois Lyotard quoted in Sven Spieker, The Big Archive: Art from Bureaucracy, 4. François Lyotard, "Domus and the Megalopolis," in The Inhuman: Reflections on Time (Stanford: Stanford University Press, 1991), 192-193 ${ }^{431}$ Ibid.
} 


\section{Conclusion}

In this chapter I have attempted to elaborate on the strategies that Calle employs to produce her archive, highlighting how the archive and what it stores emerge together. Through her transformation of the phone booth and her subsequent interactions with the people of New York City (despite her reluctance), Calle produces documents that reinforce how Calle's archive is produced through her actions, "no matter how small or how hopeless our gestures might seem to be." Action and interaction is already foregrounded through Auster and Calle's collaboration. In Gotham Handbook, Calle successfully manages to "Improve Life in New York City," and turns the daily interactions on the street into art as "documents of culture and history." 


\section{CONCLUSION: AS ARCHIVAL ABSENCE (The Wardrobe)}

Calle's work has adopted the structure of the forensic archive; it has often deliberately confused levels of reality-or, more precisely, it has successfully transformed reality (the archive) into fiction (narration), and vice versa. ${ }^{432}$

\section{The Absence of Presence}

In her article entitled "'The Artist is Present': Artistic Re-enactments and the Impossibility of Presence," Amelia Jones looks closely at Marina Abramović's recent exhibition, "The Artist is Present," at the Museum of Modern Art (MOMA) in New York City (2010). In focusing on Abramović's retrospective, Jones considers the political and theoretical implications of re-enactment and considers the impact "on the dilemma of performance histories, to explore the limits of what we can know about live art." ${ }^{433}$

"The Artist is Present" at MOMA consisted of objects, photographs and video, as well as re-enactments of Abramović's past performances by a diverse cast. The title of the exhibition and the MOMA web site describe Abramović's show in terms of presence: "In an endeavor to transmit the presence of the artist and make her historical performances accessible to a larger audience, the exhibition includes the first live re-performances of Abramović's works by other people ever to be undertaken in a museum setting. In addition, a new, original work performed by Abramović will mark the longest duration of time that she has performed a single solo piece."434

Throughout her career Jones has written extensively on the "impossibility

\footnotetext{
${ }^{432}$ Bois, "Character Study," 84.

${ }^{433}$ Jones, "The Artist is Present': Artistic Re-enactments and the Impossibility of Presence," 18.

434 "Marina Abramović: The Artist is Present," Museum of Modern Art, New York, 2010. http://www.moma.org/visit/calendar/exhibitions/965 (accessed October 28, 2014)
} 
of presence," by challenging the ways in which the live act has been "privileged, as delivering an authentic and 'present' body...."435 For Jones, the performer's body cannot be understood as a guarantee of presence, an unmediated experience of the body (and implied self) of the performer. Jones uses "The Artist is Present" to argue that there "cannot be a definitively 'truthful' or 'authentic' form of the live event even at the moment of its enactment-not even (if this could be imagined) as lodged within the body that originally performed or experienced it." ${ }^{436}$ She asks: "Where would such a version of the live event reside at any rate? In the minds/bodies of the 'original' performer(s) or spectator(s)? In the documents that seem indexically to fix in time and space what 'really' happened? In the spaces where it took place?"437

In her important essay on performance documentation, "'Presence' in Absentia: Experiencing Performance As Documentation," Jones emphasizes that neither experiencing a performance nor viewing documentation and residue from a performance has a "privileged relationship to the historical 'truth'.,438 Jones clearly understands, however, that there is a different "specificity of knowledge gained" from both experiencing live art as well as studying the "documentary traces of such an event." 439

In my discussions of Calle's projects I have only briefly touched on discussions of 'presence,' as I believe that the strength of autofiction brings the impossibility of presence, origin, and authenticity into focus in a different way.

\footnotetext{
${ }^{435}$ Jones, "'The Artist is Present': Artistic re-enactments and the Impossibility of Presence," 17. ${ }^{436}$ Ibid., 19.

${ }^{437}$ Ibid.

438 Jones, “'Presence' in Absentia: Experiencing Performance as Documentation," 11.

${ }^{439}$ Ibid., 12.
} 
As I have argued throughout this thesis, the use of autofiction, more specifically the relationship of the autofictional event to Calle's autofictional remains, draws attention to the ways in which we can never retrieve the full history of the event, but also underlines how we understand that the event itself is never "present," which is made more obvious in Calle's work through her use of undecideability, fiction, and absence. I have remarked on the ways in which absence, not as an antithesis to presence, but rather as a gap, a space, a contradiction, emphasizes the impossibility of return and origin. I suggest that Calle's work reiterates and remakes past events not only through her interplay with Auster and her "mingling of fact with fiction," but also through repetition and difference, and does so in a way that refuses to engage in the reification of an original and fixed event. The event, as text, is always open to reinvention, retelling, and reenactment.

I want to wrap up my discussion of the relationship between Double Game, autofictional acts, and performance remains by looking briefly at The Wardrobe. This was a durational project in which Calle sent an article of clothing yearly to a man she found attractive, but who was wearing an " ugly tie." Calle writes:

I saw him for the first time in December 1985, at a lecture he was giving. I found him attractive, but one thing bothered me: he was wearing an ugly tie. The next day I anonymously sent him a thin brown tie. Later, I saw him in a restaurant and he was wearing it. Unfortunately it clashed with his shirt. It was then that I decided to take on the task of dressing him from head to toe: I would send him one article of clothing every year at Christmas. ${ }^{440}$

\footnotetext{
${ }^{440}$ Calle, The Wardrobe, 34-35. In the French boxed set, this project is paired with Le striptease under the title Les panoplies. The first project in which Calle takes off her clothes, is
} 
The Wardrobe (1985-1993) consists of a series of colour photographs of articles of clothing against a non-descript white background (much like the photographs of food we see in Gotham Handbook) accompanied by a textual description of what we see: "a thin brown tie," "a pair of silk gray socks," "a black alpaca sweater," "a white shirt," "gold plated cufflinks," "a pair of boxer shorts with a Christmas-tree pattern," and finally, "a pair of gray trousers" (figure 54, figure 55). As in Gotham Handbook the photographs are both anticipatory and historical and are asked to function as an archival record.

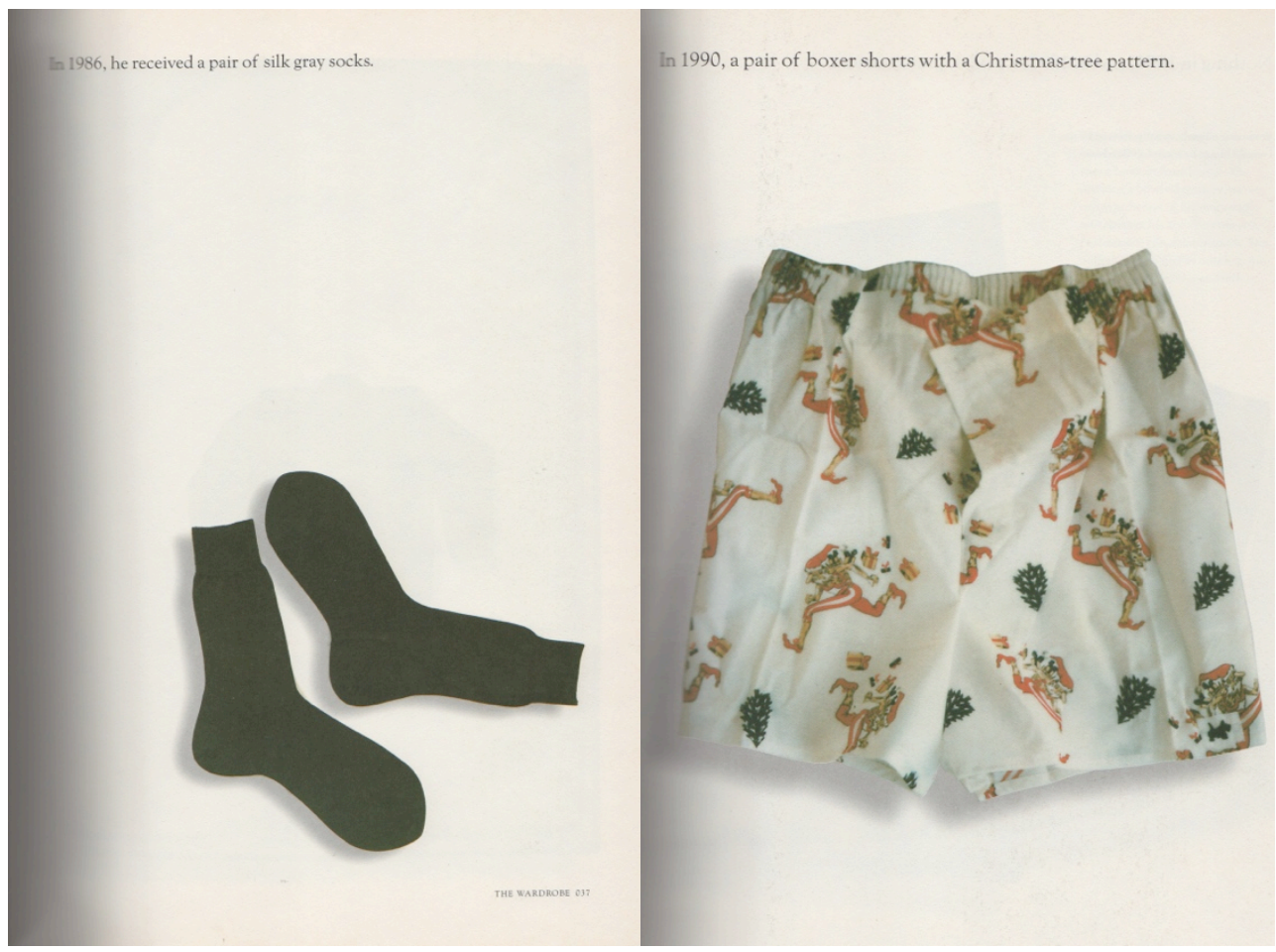

Figure 54. Calle, The Wardrobe, Double Game, 37. Figure 55. Calle, The Wardrobe, Double Game, 41.

paired with the Wardrobe where Calle dresses a man she barely knows. Here, sexual difference is enhanced and accentuated through their relationship to their outfits [les panoplies]. 
Absent is the body of Sophie Calle, proof of the parcels sent, and evidence that the man wore the clothes sent to him (supposedly) by Calle. As in Gotham Handbook, the transactions are missing. We can never "know" from the "evidence" provided if Calle (and the absent stranger) performed these actions as described in the text. We return to the question that Martha Buskirk asks of Acconci's and Calle's projects, the "challenge they [the photographs] pose" is whether to "believe the artists' claims to have done what they describe." ${ }^{\text {"41 }}$ But as I have insisted, my aim is not to assess the truth of these narrated acts but rather to highlight the ways in which the visual and discursive traces are always tentative.

Double Game plays with the archive and how it has been conceived, and enacts a shift from the archive as a space of containment and preservation to an active site of engagement. Calle plays with her own archival traces to narrate her autofictional events and opens her archive to interpretation, to multiple formulations of "what happened." Absence, not presence, is what Calle foregrounds in her work.

Useful in considering the relationship between performance and archives is Documentation, Disappearance and the Representation of Live Performance, in which Matthew Reason offers new ways of thinking about absence and the archive, one that also denies the persistence of presence. Rather than stressing the ephemerality of the performance, Reason considers how disappearance is reiterated through documentation itself. He suggests that it is always already impossible for the documents to tell the "whole story," a condition of the

${ }^{441}$ Buskirk, The Contingent Object of Contemporary Art, 221. 
document, which is always partial and incomplete. He writes: "A documentation that tells the whole story is not documentation, but the whole story; not a recording but the thing itself." ${ }^{442} \mathrm{He}$ argues that the discourse of documentation "continually reinscribes perceptions of ephemerality; the act of documentation [always partial and incomplete] marks and brings into being the fact of disappearance." ${ }^{443}$ In this sense then, the "performing art archive makes physical the dichotomy of documentation and disappearance: preserved traces but not complete presence; fragmentation but not complete disappearance." 444

\section{As Archive}

I have positioned Double Game as a collection of documents-an archive of autobiographical autofictional acts—by pointing to the undecideability of Calle's documents and elaborating on how the events represented in Calle's archive may not have unfolded as described. I have attempted to show how Calle's archive collapses the boundaries between truth and fiction, life and art, documentary and illustration, performance and its documentation. I have also emphasized play as a strategy to unhinge such binaries and move away from the fixity of material traces.

Throughout my dissertation I have highlighted a double impulse in Double Game, one that relies on the forms and structures associated with truthtelling (autobiography, photography and the diary-often considered a female form of record keeping), only to demonstrate their limits by stressing the manner by which Calle's documents expose these limits and fictions, and thus

\footnotetext{
${ }_{442}^{42}$ Reason, Documentation, Disappearance and the Representation of Live Performance, 27. ${ }^{443}$ Ibid.

${ }^{444}$ Ibid., 37.
} 
"render all totalization, fulfillment, [and] plentitude impossible." ${ }^{445}$ Double Game challenges the archive's "former stability, function, use and meaning." ${ }^{446}$ In Calle's projects, the archive, as repository and as a mechanism of control and regulation has been transformed into an archive as a generative space for interaction.

\section{The Archive, Gender, and Narrative}

Calle's autofictional records open the archive to play, confronting not only the kinds of documents (historical, official, and bureaucratic) that archives typically house, but also reconsidering women's relationship to the archive as it relates to representation and subjectivity. ${ }^{447}$ In a short article entitled "Performativity, Autobiographical Practice, Resistance," feminist literary critic Sidonie Smith claims that the "autobiographical speaker becomes a performative subject." 448 Smith looks at how Judith Butler's concept of gender performativity can be adapted to autobiography. Smith suggests that like gender, autobiographical identity is performatively constituted. Butler has argued that: "Performativity is not a singular 'act,' for it is always a reiteration of a norm or set of norms, and to the extent that it acquires an act-like status in the present, it conceals or dissimulates the conventions of which it is a repetition." 449

If, as Smith argues, the autobiographical subject is continually reproduced through pervasive modes of hegemonic discourse and strategies,

\footnotetext{
445 Jacques Derrida, "Afterword: Towards an Ethic of Discussion," 116.

${ }^{446}$ Simone Osthoff, Performing the Archive (New York, Dresden: Atropos Press, 2009), 11.

${ }^{447}$ For a nuanced reading of women and archives see Antoinette M. Burton, "Memory Becomes Her: Women, Feminist, History and the Archive," in Dwelling in the Archive: Women, Writing, House, Home and History in Late Colonial India (Oxford: Oxford University Press, 2003). ${ }^{448}$ Smith, "Performativity, Autobiographical Practice, Resistance," 108.

449 Judith Butler, "Introduction," Bodies that Matter, (London and New York: Routledge, 1993),
} 12. 
then autobiography emerges as a way of constituting and regulating "bourgeois subjects". Calle's merging of autobiography with fiction can thus be read as a strategy of resistance—not only to autobiography's hegemonic conventions, but also to earlier concepts of female subjectivity in representation. For if, as Smith observes, the autobiographical subject as a "unified, coherent and autonomous self" fails—since the autobiographical subject is "amnesiac, incoherent and heterogeneous"- then it is this very failure that opens up performative possibilities. ${ }^{450}$ Butler argues: "If gender attributes and acts, the various ways in which a body shows or produces its cultural signification, are performative, then there is no preexisting identity by which an act or attribute might be measured; there would be no true or false, real or distorted acts of gender, and the postulation of a true gender identity would be revealed as a regulatory fiction. ${ }^{451}$

I propose that Double Game is the archive in which the autobiographical autofictional subject is performatively constituted; Calle's work brings together multiple and often competing discourses and reiterates the ways in which there is no prior or original autobiographical subject (a particular ontological understanding of identity as coherent and fixed) before narration. The autobiographical subject is only real to the extent that it is performed, thus helping, yet again, to collapse the boundaries between truth and fiction, origin

\footnotetext{
${ }^{450}$ Smith, "Performativity, Autobiographical Practice, Resistance," 110.

451 Judith Butler, "Performative Acts and Gender Constitution: An Essay in Phenomenology and Feminist Theory," Theatre Journal 40, 4 (December 1988): 528.
} 
and repetition: "the self that is said to be prior to the autobiographical reflection is an effect of the autobiographical storytelling." ${ }^{452}$

\section{Sophie Calle as Archival Absence?}

In this dissertation, I have focused on archival absences as a strategy that makes more obvious the impossibility of ever retrieving the full history of an event or the complete archive. There is always space between what is experienced and what is documented, what is collected and what is archived, and how we narrate and interpret these remains. In Chapter Three, I pay particular attention to those projects that rely on archival absence. There is much that is excluded in Calle's projects. As performance residue-remains and traces of gestures enacted over time-the photographs and texts speak not only to what is documented but also to the gaps and omissions, which are equally important.

The inability of the documents provided to render the experiences described in their totality can be extended to Double Game as an archive of autobiographical acts, which points to the ways in which we can never fully know the autobiographical subject. Inevitably we return to the premise of this dissertation, an interrogation of Calle's autofictional remains. The fictions, the gaps, and the omissions in Double Game I read as clues or traces of the disappeared author.

\section{Repetition and Interpretation}

In Leviathan, the main character Peter Aaron observes Maria: "Everything was play for Maria, a call to constant invention. It was all fairly childish, I suppose,

${ }^{452}$ Smith, "Performativity, Autobiographical Practice, Resistance," 109. 
but Maria took these escapades seriously—not as diversions but as experiments, studies in the shifting nature of the self." ${ }^{453}$ By framing Double Game, literally through Auster's Leviathan, we are forced to read relationally, comparing and contrasting the events described in both Leviathan and Double Game, made most obvious through Calle's annotations to Auster's pages inserted at the beginning of the book, but also through the continual repetition of Auster's novel at the start of each new project. As we compare and contrast documents we mimic the operations of the archivist, of the historian, and of Calle who narrates her own archival residue.

Calle's règles de jeu and/or Auster's instructions underline the ways in which every utterance, every act, can be repeated-it is the same but never identical. Reiteration, citation, and repetition point to the iterability of the sign which, according to Derrida, "can be cited, put between quotation marks; in so doing it can break with every given context, engendering an infinity of new contexts in a manner which is absolutely illimitable." ${ }^{.454}$

\section{Textuality}

Della Pollock writes:

Contemporary discourses of history, culture, and identity seem still to be spinning in "textuality," feeling the loss of reference as a loss of bearings, feeling suddenly, uneasily lifted from ready cartologies of meaning into an Oz-like world not of meaninglessness exactly but of duplicity, doubleness, and simulation. From the eye of this storm, what is/was is always on the verge of becoming something else. Words don't stick. They are "Janus-faced," "fickle," indifferent to discourses of truth and meaning.... But with each turn and return to language, "textuality" seems to increasingly fold in on itself, to turn back

\footnotetext{
${ }^{453}$ Auster, Leviathan, 86.

${ }^{454}$ Derrida, "Signature Event Context," 12.
} 
on the very act of writing, making it difficult if not impossible to make sense, to make claims, to make meaning, making writing its own subject, object, which duly unwrites itself... ${ }^{455}$

If, as I suggest, Calle challenges the referentiality of her autobiographical utterances and autobiographical acts, how do we make Double Game mean? If the boundaries between fact and fiction, absence and presence, life and art, documentary and illustration, have been eroded, how do we decipher and make meaning of Calle's autofictional archival traces?

\section{Archive as Trope for Interpretation}

I propose that Double Game not only opens the structure and content of the archive to play, but also offers the archive as a metaphor for constituting identity. As a trope, the archive foregrounds contingency, relationality, and plurality. Calle's narration of the autofictional events in the life of Sophie Calle demonstrate that the concept of the archive has been transformed. Calle's archive is shown to be unstable and uncertain.

The play between what occurred and what is represented, what is narrated and what is shown, between past and present, is not static or fixed but rather a constant flow of interconnections. Temporal displacement becomes entangled in this movement between: between texts, between authors, between readers. Calle opens the archive to play as texts are retold, and reinscribed.

The rules of the game have changed and so has the event, through retelling and retracing which repeats and multiplies the event, thereby reinforcing the

\footnotetext{
${ }^{455}$ Della Pollock, "Performing Writing," in The Ends of Performance, eds. Peggy Phelan and Jill Lane (New York and London: New York University Press, 1998), 73.
} 
impossibility of a univocity of meaning. As text, therefore, the event is open to endless revisions and reiterations: "a tissue of quotations." 


\section{BIBLIOGRAPHY}

Angot, Christine. "Sophie Calle: No Sex." Beaux Arts Magazine, no. 234 (November 2003): 80-83.

Asselin, Olivier and Johanne Lamoureux. "Autofictions, or Elective Identities." Parachute, no. 105 (January - March 2002): 11-18.

Auslander, Philip. "The Performativity of Performance Documentation." PAJ 84 (2006): 1-10.

- "Towards a Hermeneutics of Performance Documentation." In Kunsten A Falle: Lessons in the Art of Falling, edited by Jonas Ekeborg, 93-95. Horten, Norway: Preus Museum, 2009.

_. "Surrogate Performances: Performance Documentation and the New York Avant-garde, ca. 1964-74." In On Performativity, edited by Elizabeth Carpenter, Vol. 1 of Living Collections Catalogue. Minneapolis: Walker Art Center, 2014. http://walkerart.org/collections/publications/performativity/Surrogateperformances.

Auster, Paul. City of Glass. New York and London: Penguin Books, 1985.

—. Leviathan. New York and London: Penguin Books, 1992.

Austin, J.L. How to do Things with Words, Second Edition. Cambridge, Massachusetts: Harvard University Press, 1975 (1962).

Barthes, Roland. Camera Lucida: Reflections on Photography. Translated by Richard Howard. New York: Hill and Wang, The Noonday Press, 1981.

_. "The Death of the Author." In Image, Music, Text. Translated by Stephen Heath, 142-148. New York: Hill and Wang, 1977.

- . "Ornamental Cookery." In Mythologies. Translated by Annette Lavers, 78-80. London: Paladin, 1973.

_. Roland Barthes by Roland Barthes. Translated by Richard French. New York: Hill and Wang, 1977.

—. "Striptease." In Mythologies. Translated by Annette Lavers, 84-87. London: Paladin, 1973.

_ . "The World of Wrestling." In Mythologies. Translated by Annette Lavers, 15-25. London: Paladin, 1973. 
Batchen, Geoffrey. Burning with Desire: The Conception of Photography. Cambridge, Massachusetts: The MIT Press, 1997.

Baudrillard, Jean and Marc Guillaume. "Artificiality and Seduction." In Radical Alterity. Translated by Ames Hodges, 113-141. Los Angeles: Semiotexte, 2008 (1994).

Baudrillard, Jean. "Please Follow Me." In Suite vénitienne, 76-86. Seattle: Bay Press. 1988 (1983). Reprinted in Sophie Calle the Reader, edited by Andrea Tarsia, with Hannah Vaughn and Candy Stobbs, 17-26. London: The Whitechapel Gallery, 2009.

Baudry, Pierre. "Droit de réponse à Sophie Calle: Calle, calepin, calembredaines." Libération, mercredi le 28 septembre, 1983, 10.

Belknap, Robert E. "The Literary List." In The List: The Uses and Pleasures of Cataloguing, 1-35. New Haven and London: Yale University Press, 2004.

Benstock, Shari. "Authoring the Autobiographical." In The Private Self: Theory and Practice of Women's Autobiographical Writings, 10-33. Chapel Hill: University of North Carolina Press, 1988.

Berger, John. Ways of Seeing. London; Middlesex: British Broadcast Corporation and Penguin Books, 1972.

Blazwick, Iwona. "Introduction: Talking to Strangers." In Sophie Calle the Reader, 7-16. London: The Whitechapel Gallery, 2009.

Bloois, Joost de. "The artists formerly known as... or, the loose end of conceptual art and the possibilities of 'visual autofiction'." Image [\&] Narrative [e-journal] 19 (2007) http://www.imageandnarrative.be/autofiction/debloois.htm

Bois, Yves-Alain. "Character Study: Sophie Calle." Art Forum International. 38, 8 (April 2000): 120-131. Reprinted in Sophie Calle: The Reader, 83-89. London: The Whitechapel Gallery, 2009.

_. "In Conversation: Rosalind Krauss and Yve-Alain Bois," The Brooklyn Rail: Critical Perspectives on Arts, Politics and Culture, February $1^{\text {st }}$, 2012. http://www.brooklynrail.org/2012/02/art/rosalind-krauss-with-yvealain-bois

_. "Paper Tigress." October 116 (Spring 2006): 35-54. 
Bond, Henry. "Hard Evidence." Lacan at the Scene, 7-26. Cambridge, Massachusetts: The MIT Press, 2009.

Borggreen, Gunhild and Rune Gade. "Introduction: The Archive in Performance Studies." In Performing Archives/Archives in Performance, 9-30. Copenhagen: Museum Tusculanum Press and University of Copenhagen, 2013.

Bouillier, Grégoire. The Mystery Guest. Translated by Lorin Stein. New York: Farrar, Strauss + Giroux, 2006.

Boyle, Claire. "Chapter 1: Autobiography, Orthodoxes, Paradoxes." In Consuming Autobiographies: Reading and Writing the Self in Post-War France, 11-29. Leeds: Modern Humanities Research Association and W.S. Maney and Son Ltd., 2007.

Brooks, Peter. "Fictions of the Wolf Man." In Reading for the Plot: Design and Intention in Narrative, 264-285. New York: Vintage Books, 1985 (1984).

Bunkers, Suzanne L. and Cynthia A. Huff. "Issues in Studying Women's Diaries: A Theoretical and Critical Introduction." In Inscribing the Daily: Critical Essays on Women's Diaries, 1-22. Massachusetts: University of Massachusetts Press, 1996.

Burke, Seán. The Death and Return of the Author: Criticism and Subjectivity in Barthes, Foucault and Derrida. Edinburgh: Edinburgh University Press, 1992.

Burton, Antoinette. "Memory Becomes Her: Women, Feminist, History and the Archive." In Dwelling in the Archive: Women, Writing, House, Home and History in Late Colonial India, 3- 30. Oxford: Oxford University Press, 2003.

Buskirk, Martha. "Contingent Objects." In The Contingent Object of Contemporary Art, 211-259. Cambridge, Massachusetts: The MIT Press, 2003.

Butler, Judith. "Introduction." Bodies that Matter, 1-23. London and New York: Routledge, 1993.

- "Performative Acts and Gender Constitution: An Essay in Phenomenology and Feminist Theory." Theatre Journal 40, no. 4 (December, 1988): 519-531.

Calle, Sophie with the participation of Paul Auster. Double Game. London: Violette Editions, 1999. 
—. Doubles-jeux. Arles: Actes Sud, 1998.

Calle, Sophie. Appointment with Sigmund Freud. London: Thames and Hudson in association with Violette Editions, 2004.

—. Des histoires vraies. Arles: Actes Sud, 1994.

—. Des histoires vraies + dix. Arles: Actes Sud, 2002.

—. Douleur exquise. Arles: Actes Sud, 2003.

__. "I asked for the moon and I got it." The Guardian, January 9, 2011. http://www.theguardian.com/artanddesign/2011/jan/09/sophie-calle

Chadwick, Whitney. "Body as Subject: Four Contemporary Women Artists." In Beyond French Feminisms: Debates on Women, Politics and Culture in France, 1981-2001, edited by Roger Célestin, Eliane Dalmolin and Isabelle de Courtivron, 143-153. New York: Palgrave MacMillan, 2003.

- "Three Artists/Three Women: Orlan, Annette Messager and Sophie Calle." Contemporary French and Francophone Studies 4 (2000): 111-118.

Chaillou, T. "Interview with Sophie Calle." The White Review, Issue 8 (July 2013) http://www.thewhitereview.org/interviews/interview-with-sophie-calle/)

Cocker, Emma. "Desiring to be Led Astray." Papers of Surrealism 6 (Autumn 2007): 1-30.

Codebò, Marco. Narrating from the Archive: Novels, Records and Bureaucrats in the Modern Age. Cranbury, New Jersey: Rosemont Publishing, 2010.

Cook, Terry. "Archival Science and Postmodernism: New Formulations for Old Concepts. Archival Science 1 (2001): 3-24.

Cook, Terry and Joan M. Schwartz. "Archives, Records, Power: From (Postmodern) Theory to (Archival) Performance." Archival Science 2 (2002): 171-185.

Cooke, Lynn. "Double Blind: Interview with Sophie Calle and Greg Shephard." Art Monthly 163 (February 1992). Reprinted in Sophie Calle: The Reader, 59-65. London: Whitechapel Gallery, 2009. 
Cosslett, Tess, Celia Lury and Penny Summerfield, Eds. Feminism and Autobiography: Text, Theory, Method. London and New York: Routledge, 2000.

Costello, Diarmuid and Margaret Iverson, Eds. Photography After Conceptual Art. United Kingdom: Blackwell Publishing, 2010.

Cousineau, Penny. 'In my Fantasies, I'm the Man,' Sophie Calle's True Stories." Parachute, no. 82 (April - June 1996): 11-15.

Darrieussecq, Marie. "L'Autobiographie, un genre pas serieux." Poetique 107 (1996): 369-380.

Derrida, Jacques. "Afterword: Towards an Ethic of Discussion." In Limited Inc, edited by Gerald Graff. Translated by Samuel Weber, 111-154. Evanston, Illinois: Northwestern University Press, 1988 (1977).

Archive Fever: A Freudian Impression. Translated by Eric Prenowitz. Chicago and London: The University of Chicago Press, 1996.

- Copy, Archive, Signature: A Conversation on Photography. Translated by Jeff Fort. Stanford, California: Stanford University Press, 2010.

_. "Différance." In Margins of Philosophy. Translated by Alan Bass, 1-28. Chicago: University of Chicago Press, 1982.

Positions. Translated by Alan Bass. Chicago: University of Chicago Press, 1972.

_. "Signature Event Context." In Limited Inc, edited by Gerald Graff. Translated by Samuel Weber, 1-23. Evanston, Illinois: Northwestern University Press, 1988.

Doane, Mary Ann. "Film And the Masquerade: Theorizing the Female Spectator." Screen 23, 3-4 (1982): 74-87.

Doubrovsky, Serge. Autobiographiques: de Corneille à Sartre. Paris: Presses universitaires de France, 1988.

—. "Autofiction." Auto/Fiction 1, no. 1 (2013): 1-3.

Doyle, Jennifer. "The Strange Theatricality of Tears: Nao Bustamante's Neopolitain (2009)." In Hold it Against Me: Difficulty and Emotion in Contemporary Art, 83-88. Durham, North Carolina: Duke University Press, 2013. 
Durden, Mark. "The Authority of Authenticity: Tracey Emin," edited by Olivier Asselin and Johanne Lamoureux. Parachute: Autofictions no.105 (January - March 2002): 20-37.

Eakin, Paul John. Fictions in Autobiography: Studies in the Art of Self-Invention. Princeton, New Jersey: Princeton University Press, 1985.

Eco, Umberto. The Infinity of Lists. Translated by Alistair McEwen. New York: Rizzoli, 2009.

Enwezor, Okwui. Archive Fever: Uses of the Document on Contemporary Art. New York: International Centre of Photography, 2008

Ferreira-Meyers, Karen. "Historical Overview of a New Literary Genre: Autofiction." Auto/Fiction 1, no.1 (2013): 15-35.

Forte, Jeanie. "Women's Performance Art: Feminism and Postmodernism." Theatre Journal 40, no. 2 (May 1998): 217-235.

Foster, Hal. "The Archive without Museums." October 77 (Summer 1996): 97119.

—_. "An Archival Impulse." October 110 (Fall 2004): 3-22.

_ . "The Artist as Ethnographer." In The Return of the Real: The AvantGarde at the End of the Century, 171-204. Cambridge, Massachusetts: The MIT Press, 1996.

Foucault, Michel. "The Historical A Priori and the Archive." In The Archeology of Knowledge. Translated by A. M. Sheridan Smith, 142-150. London and New York: Routledge, 2002.

Freshwater, Helen. "The Allure of the Archive." Poetics Today 24, no. 4 (Winter 2003): 729-758.

Freud, Sigmund. "Fetishism." In Sigmund Freud, Volume Seven: Three Essays on Sexuality and Other Works. Translated by James Strachey, 351-357. England: Penguin Books Ltd, 1977 (1952).

_. "From the History of an Infantile Neurosis [The 'Wolfman']." In The "Wolfman" and Other Cases. Translated by Louise Adey Huish. 203-320. London: Penguin Books, 2002 (1918).

_- "The Uncanny." In The Uncanny. Translated by David Mclintock, 123162. London, New York: Penguin Editions, 2003 (1919). 
Frey, Patrick. "Tombstones, Inscriptions, Photographs, Captions: The Hyperfiction of Life and Death." Parkett 36 (1993): 105-108. Reprinted in Sophie Calle: The Reader, 67-70. London: Whitechapel Gallery, 2009.

Giannachi, Gabriella, Nick Kaye and Michael Shanks, eds. Archeologies of Presence: Art, Performance and the Persistence of Being. London and New York: Routledge, 2012.

Gade, Rune and Anne Jerslev. "Introduction." In Performative Realism: Interdisciplinary Studies in Art and Media, edited by Rune Gade and Anne Jerslev, 7-10. Denmark: Museum Tusculanum Press, 2005.

Gasparini, Philippe. "Autofiction vs Autobiography." Auto/Fiction 1, no. 1 (July 2013): 4-14.

Gannon, Susanne. "The (Im)Possibilities of Writing the Self-Writing: French Poststructural Theory and Autoethnography." Cultural Studies $\leftrightarrow$ Critical Methodologies (2006): 474-495.

Genette, Gérard. "Chapter 2: Acts of Fiction and Diction." In Chapter Two: Acts of Fiction. Translated by Catherine Porter, 30-53. New York: Cornell University Press, 1993.

_. "Fictional Narrative, Factual Narrative." Poetics Today: Narratology Revisited 11, no. 4 (Winter, 1990): 755-774.

Geralnik, Nehama. Sophie Calle: True Stories. Tel Aviv: Tel Aviv Museum of Art, 1997.

Gervais, Bertrand and Maite Snauwaert. Intermédialitiés: Histoire et théorie des arts et des techniques: Filer (Sophie Calle) numéro 7. Montreal: Université de Montréal, 2007.

Gilmore, Leigh. Autobiographics: A Feminist Theory of Women's SelfRepresentation. Ithaca and London: Cornell University Press, 1994.

Gonzalez, Jennifer. "Autotopographies." In Prosthetic Territories: Politics and Hypertechnologies, edited by Gabriel Brahm and Mark Driscoll, 133-150. San Francisco: Westview Press, 1995.

Gratton, Johnnie and Michael Sheringham. "Introduction: Tracking the Art of the Project: History, Theory Practice." In The Art of the Project: Projects and Experiments in Modern French Culture, edited by Johnnie Gratton and Michael Sheingham, 1-30. Oxford: Berghan Books, 2005. 
Gratton, Johnnie. "Experiment and Experience in the Phototextual Projects of Sophie Calle." In Women's Writing in Contemporary France, edited by Gill Rye and Michael Worton, 157-170. Manchester and New York: Manchester University Press, 2002.

- "'Du documentaire au documontage: Vingt ans après de Sophie Calle," 167-179. Intermédialitiés: Histoire et théorie des arts et des techniques: Filer (Sophie Calle) numéro 7. Montreal: Université de Montréal, 2007.

- "llustration Revisited: Phototextual Exchange and Resistance in Sophie Calle's Suite vénitienne." In Textual and Visual Selves: Photography, Film, and Comic Art in French Autobiography, edited by Amy L. Hubbell Ann Miller, and Natalie Edwards, 139-166. Lincoln and London: University of Nebraska Press, 2011.

- "On the Subject of the Project." In The Art of the Project: Projects and Experiments in Modern French Culture, edited by Johnny Gratton and Michael Sheringham, 123-139. Oxford: Berghan Books, 2005.

_ . "Sophie Calle's Des histoires vraies: Irony and Beyond." In Phototextualities: Intersections of Photography and Narrative, edited by Alex Hughes and Andrea Noble, 191-197. Albuquerque: University of New Mexico Press, 2003.

Griffith, Jeanine. "Watching the Detectives: Sophie Calle and Paul Auster." Creative Camera no. 354 (October-November 1998): 16-19.

Grosz, Elizabeth. "Sexual Signatures: Feminism After the Death of the Author." In Space, Time and Perversion, 9-24. London and New York: Routledge, 1995.

Guerrin. Michel. "Sophie Calle: de la douleur comme un art." Le Monde, le 8 juin, 2007.

Guibert, Hervé. "Panégyrique d'une faiseuse d'histoire." Sophie Calle: à suivre. Paris: Musée d'art moderne de la ville de Paris, 1991.

—. "Les Tribulations de Sophie Calle en enfance." Arts et Spectacles, Le Monde, le 16 août 1984.

Guichard, Jean-Paul. "Poker menteur: de la photographie comme preuve de l'existence de Sophie Calle." In Traces photographiques, traces autobiographiques, edited by Danièle Méaux et Jean-Bernard Vra, 7381. St-Étienne: Publications de l'Université de Saint-Étienne, 2004. 
Hand, Janet. "Sophie Calle's Art of Following and Seduction." Cultural Geographies no. 12 (2005): 463-484.

Heti, Shelia. "Sophie Calle." The Believer (June 2012): 45-52.

Hubert, Renee Riese and Judd D. Hebert, The Edge of Reading: Artist's Books. New York: Granary Books, 1999.

Hughes, Alex. "Recycling and Repetition in Recent French 'Autofiction': Marc Weitzmann's Doubrovskian Borrowings." The Modern Language Review 97, no. 3 (July 2002): 566-576.

Ince, Kate. "Games with the Gaze: Sophie Calle's Postmodern Photoextuality." In The Art of the Project: Projects and Experimentation in Modern French Culture, edited by Johnnie Gratton and Michael Sheringham, 111-122. Oxford: Berghan Books, 2005.

Iser, Wolfgang. "Feigning in Fiction." In Identity of the Literary Text, edited by Mario J. Valdes and Owen Miller, 204-228. Toronto, Buffalo, London: University of Toronto Press, 1985.

Iverson, Margaret. "Auto-maticity: Ruscha and Performative Photography." In Photography After Conceptual Art, edited by Diarmuid Costello and Maraget Iversen, 12-27. United Kingdom: Wiley-Blackwell, 2010.

- . "Following Pieces: On Performative Photography." In Photography Theory, edited by James Elkins, 91-108. London and New York: Routledge, 2007.

Jacobus, Mary. "Freud's Mnemonic: Women, Screen Memories, and Feminist Nostalgia." Michigan Quarterly Review 26, 1 (Winter 1987): 117-139.

Jalving, Camilla."Inventing Reality: On Truth and Lies in the Work of Hayley Newman." In Performative Realism: Interdisciplinary Studies in Art and Media, edited by Rune Gade and Anne Jerslev, 145-180. Denmark: Museum Tusculanum Press, University of Copenhagen, 2005.

Jeffries, Stuart. "Sophie Calle: stalker, stripper, sleeper, spy." Culture>Art and Design>Art, The Guardian, 23 September 2009. http://www.theguardian.com/artanddesign/2009/sep/23/sophie-calle

Jones, Amelia. "'The Artist is Present': Artistic Re-enactments and the Impossibility of Presence." TDR 55, no. 1 (Spring 2011): 16-45.

. Body Art/Performing the Subject. Minneapolis: University of Minnesota Press, 1998. 
_- "Performing the Other as Self: Cindy Sherman and Laura Aguilar Pose the Subject." In Interfaces: Women/Autobiography/Image/Performance, edited by Sidonie Smith and Julie Watson, 69-102. Ann Arbor: University of Michigan Press, 2002.

_. "'Presence' in Absentia: Experiencing Performance as Documentation." Art Journal 56, no.4 (Winter 1997): 11-18.

Jones, Elizabeth Houston. "Serge Doubrovsky: Life, Writing, Legacy." L'Esprit Créateur 49, no. 3 (2009): 1-7.

- Spaces of Belonging: Home, Culture, Identity in 20th Century French Autobiography. Amsterdam and New York: Editions Rodopi, 2007.

Jordan, Shirley. "État Présent: Autofiction in the Feminine." French Studies, LXVII, no. 1 (2012): 76-84.

—_. "Exhibiting Pain: Sophie Calle's Douleur exquise." French Studies: A Quarterly Review 61, no. 2 (April 2007): 196-208.

_- "Performance in Sophie Calle's Prenez soins de vous." French Cultural Studies, 24, no. 3 (2013): 249-263.

Jovanovic, Rozalia. "Sophie Calle's Controversial 'Address Book' Will Be Published as a Book for the First Time." Culture, New York Observer, August 1, 2012. http://observer.com/2012/08/sophie-calles-controversialaddress-book-to-be-published-in-its-entirety-for-first-time/

Klima, Stefan. Artists' Books: a Critical Survey of the Literature. New York: Granary Books, 1998.

Kotz, Liz. Words to Be Looked At: Language in 1960s Art. Cambridge, Massachusetts: The MIT Press, 2010 (2007).

Krauss, Rosalind. "Notes on the Index: Seventies Art in America." October 3 (Spring 1977): 68-81.

- "Two Moments from the Post-Medium Condition." October 116 (Spring 2006): 55-62.

Küchler, Susanne. "The Art of Ethnography: The Case of Sophie Calle." In Site Specificity: The Ethnographic Turn, edited by Alex Coles, 94-109. London: Black Dog Publishing, 2000. Reprinted in Sophie Calle: The Reader, 91-102. London: Whitechapel Gallery, 2009. 
Lütticken, Sven. "Progressive Striptease." In Perform, Repeat, Record: Live Art in History, edited by Amelia Jones and Adrian Heathfield, 187-198.

Chicago: The University of Chicago Press, 2012.

Lejeune, Philippe. "The Autobiographical Pact." In On Autobiography, 3-30. Minnesota: University of Minnesota Press, 1989 (1975).

Loxley, James. Performativity. London and New York: Routledge, 2007.

Macel, Christine. "The Author Issue in the Work of Sophie Calle. Unfinished." In Sophie Calle, M'as-tu vue? 17-29. Munich, Berlin, London, New York: Prestel, 2003.

_. "Biographical Interview with Sophie Calle." Sophie Calle, M'as-tu vue? 73-83. Munich, Berlin, London, New York: Prestel, 2003.

Macel, Christine, ed. Sophie Calle, M'as-tu vue? Paris: Centre National d'Art et de Culture Georges Pompidou, 2003

Magid, Jill. "Sophie Calle: The Legendary Artist on Life, Love and Cruelty." TOKION (Fall 2008): 46-53. Reprinted as "Sophie Calle." In Sophie Calle: The Reader, 141-147. London: Whitechapel Gallery, 2009.

Man, Paul de. "Autobiography as De-Facement." MLN 94, no. 5 (December 1979): 919-930.

Mangawang, Mya. Her(e) but not Her(e). PhD Dissertation, Bryn Mawr College, 2008.

Masschelein, Anneleen. "Can Pain Be Exquisite? Autofictional Stagings of Douleur exquise by Sophie Calle, Forced Entertainment and Frank Gehry and Edwin Chan." Image [\&] Narrative [e-journal], 19 (November 2007). http://www.imageandnarrative.be/autofiction/masschelein.htm

_. "Foreward." Image [\&] Narrative [e-journal] 19 (November 2007) http://www.imageandnarrative.be/inarchive/autofiction/foreword.htm

- The Unconcept: The Freudian Uncanny in Late-Twentieth Century Theory. Albany: State University of New York, 2011.

McFadden, Cybelle. "Orchestrated Reflexivity: Sophie Calle's Narrative Body as Artist." In Gendered Frames, Embodied Cameras: Varda, Akerman, Cabrera, Calle, and Maïwenn, 145-186. Maryland: Fairleigh Dickinson University Press, 2014. 
Merewerth, Charles. "Introduction: Art and the Archive." In The Archive, Documents of Contemporary Art, edited by Charles Mereworth, 10-17. London and Cambridge, Massachusetts: Whitechapel Gallery and MIT Press, 2006.

. "A Language to Come: Japanese Photography. After the Event." In The Archive, Documents of Contemporary Art, edited by Charles Mereworth, 10-17. London and Cambridge, Massachusetts: Whitechapel Gallery and MIT Press, 2006.

Miller, Nancy. "Writing Fictions: Women's Autobiography in France." In Lifelines: Theorizing Women's Autobiography, edited by Bella Brodzki and Celeste Schenck, 45-61. Ithaca: Cornell University Press, 1988.

Moeglin-Delacroix, Anne. Ésthetique du livre d'artiste 1960/1980. Paris: Éditions Jean-Michel Place, Bibliothèque nationale de France, 1997.

Moore, Barbara and Jon Hendricks. "The Page as Alternative Space." In Artist's Books: A Critical Anthology and Source Book, 87-95. New York: Gibbs M. Smith, Inc., Pelegrine Smith Books in association with Visual Studies Workshop Press, 1985.

Morgan, Stuart. "On Sophie Calle's Suite vénitienne." Frieze 3 (January March 1992): unpaginated. Reprinted in Sophie Calle: The Reader, 4548. London: Whitechapel Gallery, 2009.

Morley, David. "Visions of the Real: The Ethnographic Arts." In Media,Modernity and Technology: The Geography of the New, 87-132. London and New York: Routledge, 2007.

Moxey, Keith. "After the Death of the "Death of the Author"." In The Practice of Persuasion: Paradox as Power in Art History, 124-142. New York: Cornell University, 2001.

Mulvey, Laura. "Visual Pleasure and Narrative Cinema." Reprinted in The Feminism and Visual Culture Reader, edited by Amelia Jones, 44-53. London and New York: Routledge, 2003 (1975).

Natalie Edwards, Amy L. Hubbell and Ann Miller, eds. Visual and Textual Selves: Photography, Film, and Comic Art in French Autobiography . Lincoln and London: University of Nebraska Press, 2011.

Nead, Lynda. The Female Nude: Art, Obscenity and Sexuality. London and New York: Routledge, 1992. 
Neri, Louise. "Sophie's Choice." Interview (April 2009): 92-97. Reprinted in Sophie Calle: The Reader. 150-154. London: Whitechapel Gallery, 2009.

Newman, Hayley. Connotations_Performance Images 1994 -1998. http://www.hayleynewman.com/artworks/show/15

Obrist, Hans-Ulrich. "Portrait Sophie Calle." Spike 9 (2006): 46-55. Reprinted in Sophie Calle: The Reader. 134-140. London: Whitechapel Gallery, 2009.

O'Dell, Kathy. "Displacing the Haptic: Performance Art, the Photographic Document, and the 1970s." Performance Research 2, 1 (1997): 73-74.

Osthoff, Simone. Performing the Archive. New York, Dresden: Atropos Press, 2009.

Perec, Georges. Life A User's Manual. Translated by David Bellos. Boston: David R. Godine, 2009 (1978).

- "Notes Concerning the Objects that are on my Work-Table." In Species of Spaces and Other Pieces. Translated by John Sturrock. London, 144-147. New York, Toronto: Penguin Books, 2008 (1974).

—_. "The Street." In Species of Spaces and Other Pieces. Translated by John Sturrock. London, 46-56. New York, Toronto: Penguin Books, 2008 (1974).

- W, or The Memory of Childhood. Translated by David Bellos. Boston: David R. Godine, 1988 (1975) .

Phelan, Peggy. "The Ontology of Performance: Representation without Reproduction." In Unmarked: the Politics of Performance, 146-166. London and New York: Routledge, 1993.

Phoca, Sophie. "She's Street-wise and a Stalker: Sophie Calle's The Birthday Ceremony." Third Text 13, no. 45 (Winter 1989-99): 101-103.

Pincus, Robert L. "The Prying Eye." Art in America (October 1989): 192-97. Reprinted in Sophie Calle: The Reader, 27-32. London: Whitechapel Gallery, 2009.

Pollock, Della. "Performing Writing." In The Ends of Performance, edited by Peggy Phelan and Jill Lane, 73-103. New York and London: New York University Press, 1998.

Rabe, Jean-Michel, Ed., Writing the Image, After Barthes. Philadelphia: University of Pennsylvania Press, 1997. 
Reason, Matthew. "Archive or Memory? The detritus of Live Performance." New Theatre Quarterly 19, no. 1 (February 2003): 82-89.

\section{- Documentation, Disappearance and the Reproduction of Live} Performance. New York: Palgrave Macmillan, 2006.

"Review: Emotional baggage and the art of Freud's soft furnishings," $E Y E$ Magazine: The International Review of Graphic Design 57 (Autumn 2005). http://www.eyemagazine.com/review.php?id=124\& $\mathrm{rid}=592$

Richard, Annie. 'La Famille autofictive de Sophie Calle." In Affaires de famille: The Family in Contemporary French Culture and Theory, edited by Marie-Claire Barnet and Edward Welch, 139-50. Amsterdam: Rodopi, 2007.

Ridge, Emily. "'SO': Tracing Georges Perec in the Work of Sophie Calle," Kaleidoscope: The Interdisciplinary Postgraduate Journal of Durham University's Institute of Advanced Studies (August 2010): 19-26.

Riding, Alan. "Keeping it Together by Living her Life in Public." New York Times, Arts and Leisure, December 7, 2003, 44-45.

Riffaterre, Michael. Fictional Truth. Baltimore and London: The Johns Hopkins University Press, 1990.

Rinder, Lawrence. "A Conversation with Sophie Calle." CALENDAR. Berkeley: University Art Museum, 1990. Non-paginated.

- "Sophie Calle and the Practice of Doubt." In Art Life: Selected Writings, 1991- 2005, 11-20. New York: Gregory R. Miller and Company, 2005.

Riviére, Joan. "Womanliness as Masquerade." The International Journal of Psychoanalysis 10 (1929): 303-313. Reprinted in Feminist Theory: A Reader, edited by Wendy Kolmar and Frances Bartowski, 146-149. New York: McGraw Hill, 2013.

Rolin, Olivier. "Beet, Alfalfa, etc." In Sophie Calle, M'as-tu vue? Edited by Christine Macel, 137-140. Paris: Centre National d'Art et de Culture Georges Pompidou, 2003.

Rugg, Judith. Sophie Calle's Appointment at the Freud Museum: Intervention or Irony?" In New Practices-New Pedagogies: A Reader, edited by Malcolm Miles, 44-55. London, New York: Routledge, 2005. 
Rugg, Linda Haverty. Picturing Ourselves: Photography and Autobiography. Chicago and London: University of Chicago Press, 1997.

Rye, Gill and Michael Worton. "Introduction." In Women's Writing in

Contemporary France: New Writers, New Literatures in the 1990s, edited by Gill Rye and Michael Worton, 1-28. Manchester and New York: Manchester University Press, 2002.

Sadoux, Marion. "Angot's Autofiction: Literature and/or Reality?" In Women's Writing in Contemporary France: New Writer's New Literatures in the 1990s, edited by Gill Rye and Michael Worton, 171-181. Manchester and New York: Manchester University Press.

Sandbye, Mette. "Performing the Everyday: Two Danish Photos Books from the 1970s." In Performative Realism: Interdisciplinary Studies in Art and Media, edited by Rune Gade and Anne Jerslev, 117-145. Denmark: Museum Tusculanum Press, University of Copenhagen, 2005.

Sante, Luc. "Sophie Calle's Uncertainty Principle." Parkett 36 (1993): 74-78. Reprinted in Sophie Calle: The Reader, 71-74. London: Whitechapel Gallery, 2009.

Santone, Jessica. "Marina Abramović's Seven Easy Pieces: Critical Documentation Strategies for Preserving Art's History." Leonardo 41, no. 2 (April 2008): 147-152.

Sauvageot, Anne. L'art chaméléon. Paris, France: Presses universitaires de France, 2007.

Sayre, Henry. The Object of Performance: The American Avant-Garde Since 1970. Chicago and London: The University of Chicago Press, 1989.

Schwartz, Joan M. and Terry Cook. "Archives, Records, Power: The Making of Modern Memory." Archival Science 2 (2002): 1-19.

Sekula, Allan. "The Body and the Archive." October 39 (1986): 3-64.

Sheringham, Michael. "After Perec: Dissemination and Diversification." In Everyday Life: Theories and Practices from Surrealism to the Present, 292-259. Oxford: Oxford University Press, 2006.

. "Checking Out: the Investigation of the Everyday in Sophie Calle's L'Hôtel." Contemporary French and Francophone Studies 10, no. 4 (December 2006): 415-424. 
Schneider, Rebecca. The Explicit Body in Performance. London and New York: Routledge, 1997.

—. "In the Meantime: Performance Remains." In Performing Remains: Art and War in Times of Theatrical Reenactment, 87-110. London and New York: Routledge, 2011.

Sontag, Susan. On Photography. New York: Picador, 1973.

Smith, Sidonie and Julia Watson, eds. Interfaces: Women, Autobiography, Image, Performance. Ann Arbour: University of Michigan Press, 2002.

_- "Introduction: Mapping Women's Self-Representation as Visual/Textual Interfaces." In Interfaces: Women, Autobiography, Image, Performance, edited by Sidonie Smith and Julia Watson, 1-48. Ann Arbour: University of Michigan Press, 2002.

—_. "The Rumpled Bed of Autobiography: Extravagant Lives, Extravagant Questions." Biography 24, no. 1 (2001): 1-14.

- Subjectivity, Identity and the Body: Women's Autobiographical Practice in the Twentieth Century. Bloomington and Indianapolis: Indiana University Press, 1993.

Smith, Sidonie. "Performativity, Autobiographical Practice, Resistance." In Women, Autobiography, Theory: A Reader, edited by Sidonie Smith and Julia Watson, 108-115. Wisconsin: University of Wisconsin Press, 1998.

Spieker, Sven. The Big Archive: Art from Bureaucracy. Cambridge, Massachusetts: The MIT Press, 2008.

Steedman, Carolyn. Dust: The Archive and Cultural History. New Brunswick, New Jersey: Rutgers University Presss, 2002.

- . "Something She Called a Fever: Michelet, Derrida, and Dust." The American Historical Review 106, 4 (October 2001): 1-26.

_. "The Space of Memory: In an Archive." History of the Human Sciences 11, no. 4 (1998): 65-83.

Stewart, Susan. On Longing: Narratives of the Minature, the Gigantic, the Souvenir, the Collection. Durham and London: Duke University Press, 1993.

Stiles, Kristine. "Performance and Its Objects." Arts Magazine 65, no. 3 (November 1990): 35-47. 
Storr, Robert, Ed. "Sophie Calle." In Dislocations, 28-89. New York: Museum of Modern Art, 1991. Reprinted in Sophie Calle: The Reader, 41-44. London: Whitechapel Gallery, 2009.

—. "Sophie Calle: la femme qui n'était pas là." Art Press, numéro 295 (November 2003): 23-28. Reprinted as "The Woman Who Wasn't There." In Sophie Calle the Reader, 104-108. London: The Whitechapel Gallery, 2009.

Sweetman, Alex. "Photobookworks: The Critical Realist Tradition." In Artists' Books: A Critical Anthology and Sourcebook, edited by Joan Lyons, 187205. Utah, Salt Lake City, New York City: Gibbs M. Smith, Inc., Peregrine Smith Books in association with Visual Studies Workshop Press, 1985.

Tarsia, Andrea. "Index." In Sophie Calle: The Reader, 162-167. London: Whitechapel Gallery, 2009.

Trofimova, Evij. "Doubles and Disappearances." In Paul Auster's Writing Machine, 95-126. New York and London: Bloomsbury, 2014.

Vaughn, Hannah, Cindy Stobbs and Andrea Tarsia Eds. Sophie Calle: The Reader. London: Whitechapel Gallery, 2009.

Wagstaff, Sheena. "C'est Mon Plaisir." Parkett 24 (1990): 6-10. Reprinted as "Such is my Pleasure Such is my Will." Reprinted in Sophie Calle the Reader, 33-39. London: The Whitechapel Gallery, 2009.

Watteau, Diane. "L'Autofiction, une vocation suspendue dans l'art contemporain?: Les <<moi en toc >> et les <<trou d'être>> de Serge Doubrovsky." L'Esprit Créateur 49, no. 3 (Fall 2009): 115-132.

Weber, Caroline. "My Funny Valentine." The Sunday Book Review, The New York Times, Feb 12, 2009.

Weintraub, Linda. "On Sophie Calle." In Art on the Edge and Over: Searching for Art's Meaning in Contemporary Society, 1970s to 1990, 66-70. Litchfield Connecticut: Art Insights Inc.,1996. Reprinted in Sophie Calle: The Reader, 75-82. London: Whitechapel Gallery, 2009.

Widrich, Mechtild. "Location and Dislocation: The Media Performances of VALIE EXPORT." PAJ 33, no. 3 (September 2011): 53-59.

Zipfel, Frank. "Autofiction." Routledge Encyclopedia of Narrative Theory, edited by David Herman and Mandfred Jahn, 36-37. New York and London: Routledge, 2007. 
Zuylen, Marina Van. "Voyeuristic Monomania: Sophie Calle's Rituals." In Monomania: Flight from Everyday Life in Literature and Art, 180-192. New York: Cornell University Press, 2005. 